\title{
Az etilén státusz szerepe a paradicsom sóstressz akklimatizációjában
}

\author{
Doktori (Ph.D.) értekezés
}

\author{
Borbély Péter Gábor
}

Témavezető:
Dr. Görgényi Miklósné Dr. Habil. Tari Irma
egyetemi docens

\author{
Biológia Doktori Iskola \\ Növénybiológiai Tanszék \\ SZTE TTIK
}

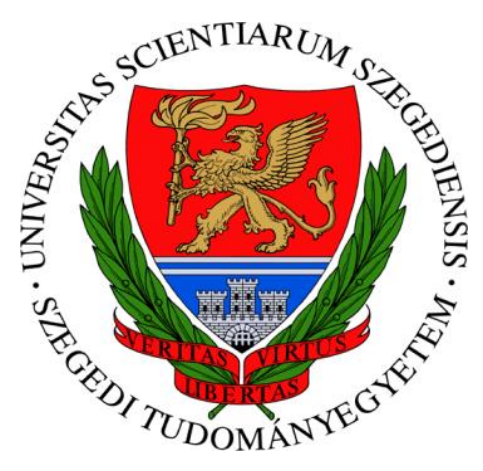

Szeged 


\section{Tartalom}

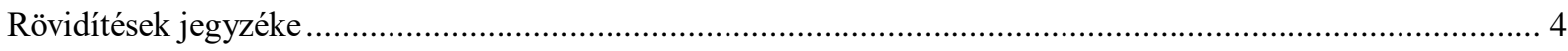

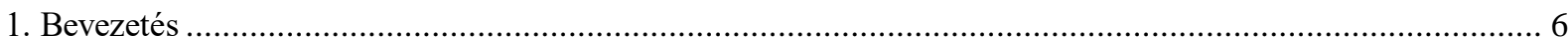

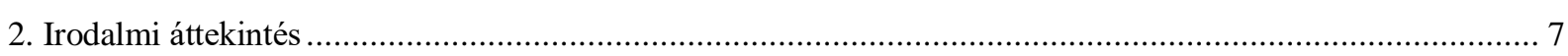

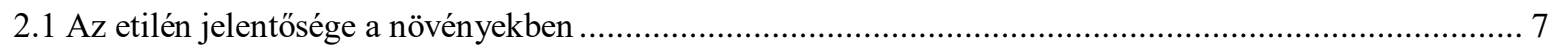

2.1.1. Az etilén bioszintézise és jelátvitele - az általános modellek és a paradicsomban megfigyelhető

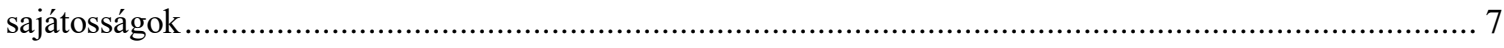

2.1.2. Az etilén szerepe a fotoszintézis szabályozásában.......................................................14

2.1.3. Reaktív oxigén- és nitrogénformák a növényekben, kölcsönhatásuk az etilénnel .........................20

2.1.4. Az etilén prekurzora, az 1-aminociklopropán-1-karbonsav (ACC) .............................................25

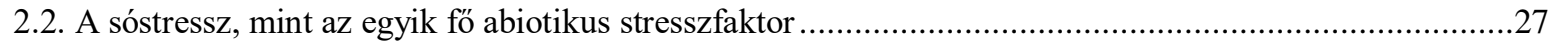

2.2.1. A sóstressz-specifikus növényélettani hatások ..............................................................28

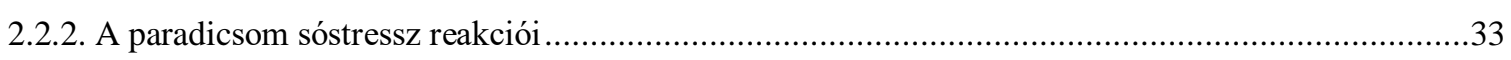

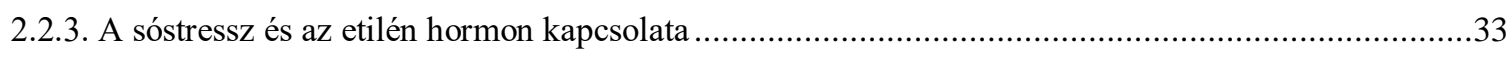

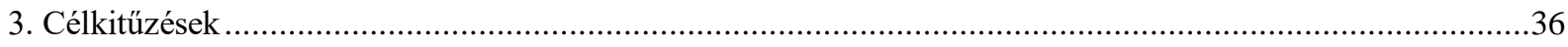

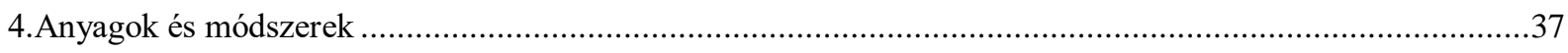

4.1 Felhasznált növényi anyag, nevelési körülmények és kísérleti elrendezések ......................................37

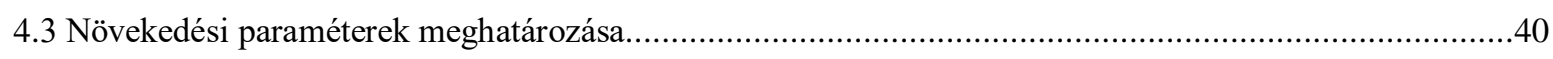

4.4 A növényi részek etilén kibocsájtásának meghatározása ...........................................................40

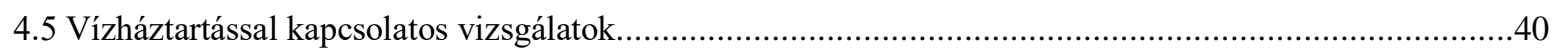

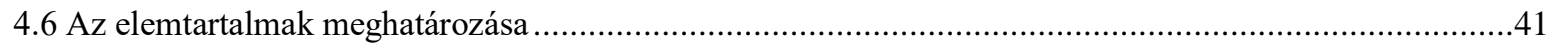

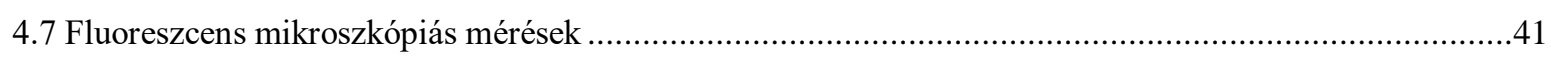

4.8 A levélszövetek $\mathrm{H}_{2} \mathrm{O}_{2}$ és $\mathrm{O}_{2}{ }^{-}{ }^{-}$akkumulációjának monitorozása......................................................42

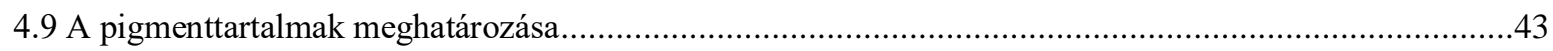

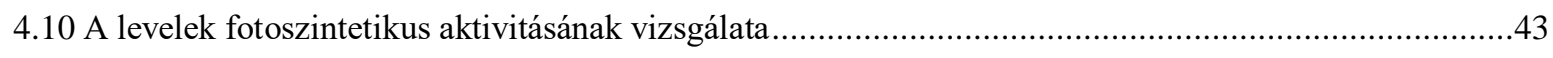

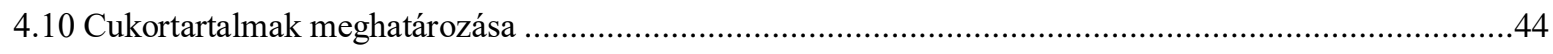

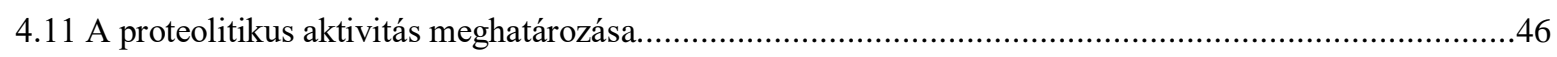

4.12 Antioxidáns enzimek aktivitásának monitorozása ...............................................................46

4.13 Egyes antioxidáns izoenzimek és a NADPH-oxidáz génexpressziójának vizsgálata............................47

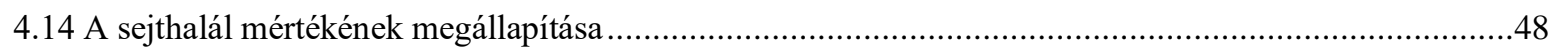

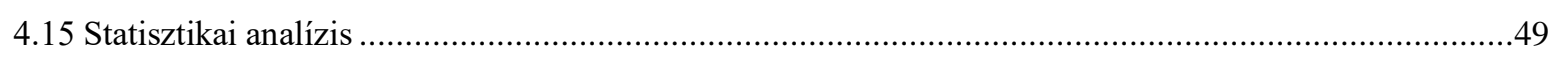

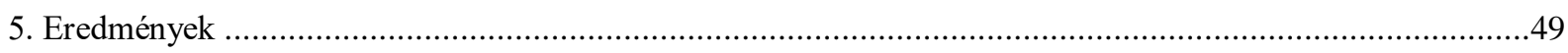

5.1. A gyökérzóna megnövekedett ACC tartalmának hatása paradicsomnövényekre, egyéb specifikus stresszfaktor alkalmazása nélkül .

5.1.1. Az ET-termelésben, a növekedésben és az iontartalmakban bekövetkező változások exogén ACC kezelés hatására.

5.1.2. Exogén ACC kezelés okozta változások a gyökércsúcsok, valamint a kifejlett, nem öregedő levelek ROS és RNF produkciójában..... 
5.1.3. A gyökérzónában kialakuló ACC többlet-indukálta változások a paradicsomnövények fotoszintetikus aktivitásában. .52

5.2. Paradicsomgyökerek só-indukálta, etilén függő válaszai.

5.2.1. Az ET jelátvitel szerepe a gyökerek sótoleranciájában, ROF és RNF produkciójában, ET receptor mutáns, Never ripe paradicsomnövényekben.

5.3. A paradicsomnövények etilén státuszától függő változások tolerálható és letális sóstressz során....

5.3.1. A só-indukált etilén produkció, a növekedés, a vízháztartás és a klorofill- valamint a $\mathrm{Na}^{+}$és $\mathrm{K}^{+}$ tartalmak változása különböző ET státuszú növényekben

5.3.2. A ROF és RNF akkumuláció só-indukált válaszainak időfüggése megemelt ET produkciójú paradicsomnövényekben

5.3.3 $\mathrm{A} \mathrm{O}_{2}{ }^{-}$és a $\mathrm{H}_{2} \mathrm{O}_{2}$ lebontásában szerepet játszó antioxidáns enzimek só-indukált aktivitásváltozásainak ET- és időfüggése

5.3.4 $\mathrm{A} \mathrm{O}_{2}{ }^{-}$és a $\mathrm{H}_{2} \mathrm{O}_{2}$ lebontásáért felelős antioxidáns enzimek, valamint az SIRBOH1 expresszió sóindukált válaszainak ET- és időfüggése

5.3.4. A fotoszintézis és az összcukor-, valamint keményítőtartalmak só-indukált válaszainak ET- és időfüggése

6. Az eredmények értékelése.

6.1.1. A gyökérkezelésként adott ACC többlet egy koncentrációs küszöbértéket meghaladva indukál szignifikáns ET emissziót, azonban ennek elérése nélkül is fiziológiai válaszokat vált ki.

6.1.2. Az exogén ACC kezelés fokozta a $\mathrm{H}_{2} \mathrm{O}_{2}$ felhalmozódást, koncentráció-függő módon befolyásolja a NO és a $\mathrm{ONOO}^{-}$akkumulációs mintázatát.

6.1.3. A gyökérzónában mutatkozó ACC többlet a koncentráció és az expozíciós idő függvényében serkentheti vagy gátolhatja a fotoszintézist és befolyásolja a két fotokémiai rendszer müködését.

6.2.1. Az ET receptor mutáns Never ripe paradicsomgyökerek érzékenyebbek a sóstresszre: a gyökércsúcsok már szubletális stressz esetén is mutatják a sejthalál jellegzetes fiziológiai tüneteit.

6.3.1. Az exogén ACC elökezelés eltérő módon befolyásolja a levél és a gyökér ET produkcióját sóstressz során, a levelek ET státusza szabályozza a vízháztartást és a klorofillok lebomlását szupraoptimális sókoncentrációkon

6.3.2. A növények ET státusza szabályozza a ROF és RNF molekulák akkumulációját a sóstressz kialakulása során

6.3.3. Az ET státusz befolyásolja a fotoszintetikus aktivitást és a cukorháztartást paradicsomnövényekben sóstressz alatt

7. Összefoglalás

8. Summary

9. Irodalomjegyzék

10. Publikációs lista.

11. Nyilatkozat.

12. Köszönetnyilvánítás

13. Mellékletek. 


\section{Rövidítések jegyzéke}

\begin{tabular}{|c|c|}
\hline $\mathrm{ABA}$ & Abszcizinsav \\
\hline $\mathrm{AC}$ & Ailsa Craig paradicsom fajta \\
\hline $\mathrm{ACC}$ & 1-aminociklopropán-1-karbonsav \\
\hline ACS & ACC szintáz (EC 4.4.1.14) \\
\hline $\mathrm{ACO}$ & ACC oxidáz (EC 1.14.17.4) \\
\hline ACCD & ACC deamináz (EC. 4.1.99.4) \\
\hline $\mathrm{A}_{\mathrm{N}}$ & Nettó $\mathrm{CO}_{2}$ asszimiláció \\
\hline ASC & Aszkorbát (redukált) \\
\hline ARGOS & $\begin{array}{l}\text { AUXIN REGULATED GENE INVOLVED IN ORGAN SIZE, } \\
\text { az ETR receptorok lebontásában szerepet játszó protein }\end{array}$ \\
\hline APX & Aszkorbát-peroxidáz (EC 1.11.1.11) \\
\hline $\mathrm{CBC}$ & Calvin-Benson ciklus \\
\hline CDPK & Ciklin-függő protein kináz \\
\hline CET & Ciklikus elektrontranszport \\
\hline CTR1 & CONSTITUTIVE TRIPLE RESPONSE, Ser/Thre kináz \\
\hline $\mathrm{Cu} / \mathrm{ZnSOD}$ & Réz/cink-szuperoxid-dizmutáz \\
\hline DAF-2DA & 4,5- diaminofluoreszcein-diacetát \\
\hline EIN2 & ETHYLENE INSENSITIVE2, etilén jelátviteli komponens \\
\hline EIN3/EIL1-4 & ETHYLENE INSENSITIVE3/EIN3 LIKE) transzkripciós faktorok \\
\hline EL & Ionkieresztés (electrolyte leakage) \\
\hline EOL1/2 & E3 ligáz \\
\hline ER & Endoplazmatikus retikulum \\
\hline ERF & ETHYLENE RESPONSE FACTOR, transzkripciós faktor család \\
\hline ET & Etilén \\
\hline ETO1 & ETHYLENE OVERPRODUCER1 E3 ligáz \\
\hline ETR & ETHYLENE RESPONSE1, etilén receptor \\
\hline FeSOD & Vas-szuperoxid-dizmutáz \\
\hline FT & Friss tömeg \\
\hline GACC & $\gamma$-glutamil- ACC \\
\hline GPX & Glutation peroxidáz \\
\hline GSNO & S-nitrozoglutation \\
\hline $\mathrm{g}_{\mathrm{sw}}$ & Sztómakonduktancia \\
\hline $\mathrm{H}_{2}$ DCFDA & 2',7'-dikloro-dihidro-fluoreszcein-diacetát \\
\hline ISR & Indukált szisztemikus rezisztencia \\
\hline $\mathrm{J}-\mathrm{ACC}$ & Jazmonil-ACC \\
\hline KAT & Kataláz (EC 1.11.1.6) \\
\hline $\mathrm{K} l a$ és $b$ & Klorofill $a$ és $b$ \\
\hline Kar & Karotinoid \\
\hline LET & Lineáris elektrontranszport \\
\hline LHC & Fénybegyüjtő komplex \\
\hline LHT1 & LYSINE HISTIDINE TRANSPORTER1 \\
\hline MAPK & Mitogén-aktivált protein kináz \\
\hline MACC & Malonil-ACC \\
\hline MDA & Malondialdehid \\
\hline $\mathrm{MES} / \mathrm{KCl}$ & 2-(N-morfolin)-etánszulfonsav/kálium-klorid \\
\hline MnSOD & Mangán-szuperoxid-dizmutáz \\
\hline MT & Micro-Tom paradicsom fajta \\
\hline MTA & Metiltioadenozin \\
\hline
\end{tabular}




\begin{tabular}{|c|c|}
\hline NADPH-oxidáz & Nikotinamid-dinukleotid-foszfát oxidáz (plazmamembrán kötött) \\
\hline NBT & Nitrotetrazólium-kék \\
\hline NO & Nitrogén-monoxid \\
\hline NOA1 & NITRIC OXIDE-ASSOCIATED 1 (NOA1) NO produkció \\
\hline NOS & Nitrogén-oxid synthase \\
\hline NOX & Plazmamembrán kötött NADPH-oxidáz \\
\hline NR & NEVER RIPE paradicsom vad típus \\
\hline$N r$ & Never-ripe (etilén receptor) paradicsom mutáns \\
\hline PA & Foszfatidsav \\
\hline PAGE & Poliakrilamid-gélelektroforézis \\
\hline PCD & Programozott sejthalál (Programmed Cell Death) \\
\hline PP2A; PP2C & Protein foszfatáz $2 \mathrm{~A}$ és $2 \mathrm{C}$ \\
\hline PK & Protein kinázok \\
\hline PM & Plazmamembrán \\
\hline PMSF & Fenil-metil-szulfonil-fluorid \\
\hline POD & Gvajakol-peroxidáz (EC 1.111.7) \\
\hline PRXR & Peroxiredoxin \\
\hline PSI & Az első fotokémiai rendszer \\
\hline PSII & A második fotokémiai rendszer \\
\hline PVPP & Polivinil-polipirrolidon \\
\hline $\mathrm{q}_{\mathrm{L}}$ & PSII reakciócentrumok nyitott frakciója fényadaptált levelekben \\
\hline qRT-PCR & Kvantitatív valós idejü polimeráz láncreakció \\
\hline RAN1 & Réz transzporter \\
\hline $\mathrm{RBOH}$ & $\begin{array}{l}\text { RESPIRATORY BURST OXIDASE HOMOLOGUE, NADPH } \\
\text { oxidázok }\end{array}$ \\
\hline RIN & RIN (RIPENING-INHIBITOR), transzkripciós faktor \\
\hline ROF & Reaktív oxigénformák (Reactive oxygen forms) \\
\hline RNF & Reaktív nitrogénformák (Reactive nitrogen forms) \\
\hline RVT & Relatív víztartalom \\
\hline $\mathrm{RuBisCO}$ & Ribulóz-1,5-biszfoszfát karboxiláz-oxigenáz \\
\hline SAM & S-adenozil-L-metionin \\
\hline S1 & Solanum lycopersicum \\
\hline SNP & Nátrium-nitroprusszid (NO generátor) \\
\hline SNAP & S-nitrozo-N-acetil-DL-penicillinamin (NO generátor) \\
\hline SOD & Szuperoxid-dizmutáz (EC 1.15.1.1) \\
\hline SZT & Száraz tömeg \\
\hline TAGL1 & TOMATO AGAMOUS-LIKE1, transzkripciós faktor \\
\hline TCA & Triklórecetsav (Trichloroacetic acid) \\
\hline XBAT32 & E3 ligáz \\
\hline Y(II) & A PSII effektív kvantumhasznosítása \\
\hline $\mathrm{Y}(\mathrm{I})$ & A PSI fotokémiai kvantumhatásfoka \\
\hline $\mathrm{Y}(\mathrm{NA})$ & $\begin{array}{l}\text { A PSI akceptor oldali limitációjából fakadó nem fotokémiai kioltás } \\
\text { kvantumhatásfoka }\end{array}$ \\
\hline $\mathrm{Y}(\mathrm{ND})$ & $\begin{array}{l}\text { A PSI donor oldali limitációjából fakadó nem fotokémiai kioltás } \\
\text { kvantumhatásfoka }\end{array}$ \\
\hline $\mathrm{Y}(\mathrm{NO})$ & Szabályozatlan nem fotokémiai energia disszipáció kvantumhatásfoka \\
\hline Y(NPQ) & Szabályozott nem fotokémiai energia disszipáció kvantumhatásfoka \\
\hline$\psi_{\mathrm{w}}$ & Vízpotenciál \\
\hline
\end{tabular}




\section{Bevezetés}

A gáz halmazállapotú növényi hormon, az etilén (ET) fontos szereppel bír a növényi életfolyamatok szabályozásában, mint például a fotoszintézis vagy a reaktív oxigén- valamint nitrogénformák akkumulációja, továbbá kiemelt résztvevője az abiotikus stresszre adott növényi válaszok kialakításának. Az exogén forrásból származó ET-t számos tanulmány során használták a hormon hatásainak feltérképezésére. Ugyanakkor a természetes körülmények között, a gyökérzónában is jelenlévő ET prekurzornak, az 1-aminociklopropán-1-karbonsavnak (ACC) hatását eddig relatíve keveset vizsgálták. Ennek következtében az exogén ACC koncentráció- és idő függvényében kifejtett befolyása a növényekre, különösen a fotoszintézisre és az említett reaktív molekulák akkumulációjára nagyrészt ismeretlen. A növények aktuális ET-érzékenysége, vagy ET produkciójának alakulása (összefoglalva: ET státusza), fontos lehet az abiotikus stressz akklimatizáció során, különös tekintettel a stresszor megjelenése elötti állapotokra. Mindezek tükrében kiemelten fontos az exogén ACC gyökérzóna-béli jelenléte által kiváltott olyan hatások azonosítása, mely az utólag jelentkező, kedvezőtlen környezeti faktorok megjelenése esetén befolyásolhatják a stresszválaszt.

A talaj vagy az öntözővíz magas sótartalma és az általa a növényekben kiváltott stresszhatás (sóstressz) a Földünk változó klímájában egyre nagyobb jelentőségüvé válik a mezőgazdasági növénytermesztésben. Ezért a növények sóstressz-válaszainak fiziológiai és molekuláris szintü felderítése alapvető szükségességet jelez. Az ET szerepe jelentős e folyamatok szabályozásában, ugyanakkor hatását nagyrészt hosszútávú sóstressz során vizsgálták, holott a stressz akklimatizáció korai időszakában - az óráktól néhány napig - történő események nagyban befolyásolják a növény későbbi sorsát. Ezen túlmenően, a reaktív oxigén(ROF) és nitrogénformák (RNF) akkumulációjának kapcsolata a növény ET státuszával rövidtávú sókezelések során alig ismert. Ugyanez elmondható a fotoszintézis esetében is, különösen az I-es fotokémiai rendszer aktivitása tekintetében. Mindezeknek megfelelően, kísérleteink során kétféle megközelítést alkalmaztunk. Vizsgáltuk a paradicsomnövények gyökérzónájában megemelt ACC koncentrációk hosszútávú hatását a fotoszintézisre és más kapcsolódó folyamatra (vízháztartás, ionakkumuláció, ROF és RNF felhalmozódás) stresszmentes körülmények között. A második megközelítésben exogén ACC (elö)kezeléssel, és az ET receptor mutációval befolyásolt különböző ET státuszú növényeket kezeltünk szubletális (növekedésgátló, de tolerálható), $100 \mathrm{mM}$-os és a letális, $250 \mathrm{mM}$-os $\mathrm{NaCl}$ koncentrációkkal és vizsgáltuk a fenti paraméterek, valamint az oxidatív stresszt meghatározó legfontosabb enzimek expressziójának és aktivitásának változását. 


\section{Irodalmi áttekintés}

\subsection{Az etilén jelentősége a növényekben}

A gáz halmazállapotú növényi hormon, az etilén (ET) a növényi életfolyamatok alapvető szabályozó molekulája. Az ET növényekre gyakorolt hatásának felfedezésekor figyelték meg az ún. hármas-választ, az ET indukálta általános morfológiai válaszreakciót etiolált borsó csíranövényekben, ennek jegyei a hosszirányú szármegnyúlás gátlása, az epikotil oldalirányú kiterjedése és a normális geotropikus válasz hiánya [1]. Az azóta világossá vált, hogy az ET a növényi növekedést és fejlődést koncentrációtól függően gátló, illetve serkentő faktorként is befolyásolhatja [2]. A gyümölcsérést elősegítő hatása mellett fontos résztvevője a növényi programozott sejthalál (PCD) kialakításának és szabályozza a növényi szövetek öregedési folyamatát, a szeneszcenciát is [3]. A PCD genetikailag kontrollált folyamat és kiemelt szerepe van növények életében, beleértve a stresszválaszokat is [4]. Az ET kiemelt résztvevője mind a biotikus- [5, 6] illetve az abiotikus növényi stresszválaszoknak. Számos abiotikus környezeti stresszor, mint a szárazság, a magas sókoncentráció stb. befolyásolja a növényi szövetek ETtermelését [7]. Az alacsony endogén ET szintek közel optimális körülmények között valószínűleg csupán enyhe hatással lehetnek növények növekedésére, mivel számos faj ETszenzitív és ET-inszenzitív genotípusai összehasonlítható ütemmel fejlődnek az említett környezeti adottságok mellett. Ugyanakkor, amikor a körülmények kevésbé optimálisak, a jól müködő ET jelátvitel alapvető lehet a növekedés fenntartásához [2]. Bár általános az a koncepció, hogy az alacsony szöveti ET tartalom serkenti, míg a magas gátolja a növényi növekedést, fontos szem előtt tartani, hogy a növényfajok között jelentős különbségek lehetnek a serkentő/gátló koncentrációk között, továbbá egyes termesztett növényfajták is különbözhetnek ET-érzékenységükben, így a hormonra adott válaszreakcióikban is $[2,8]$. Az ET növényekre gyakorolt hatása nagyban függ azok korától és állapotától, ugyanúgy, mint az esetleges stresszhatások típusától, intenzitásától és időtartalmától is [2].

\subsubsection{Az etilén bioszintézise és jelátvitele - az általános modellek és a paradicsomban megfigyelhető sajátosságok}

Az összes növényi szerv képes az ET bioszintézisére, a résztvevő kulcsenzimek szöveti megoszlása azonban eltérő lehet [9]. Az ET bioszintézisének az általános modell szerinti folyamatrendszerét és szabályozását, kiegészítve néhány paradicsomban leírt elemmel az 1. ábra foglalja össze. Az ET képződés kezdő lépése a metionin aktiválása S-adenozil-metioninná (SAM) történő átalakítása során a SAM-szintetáz enzim által (1. ábra). 


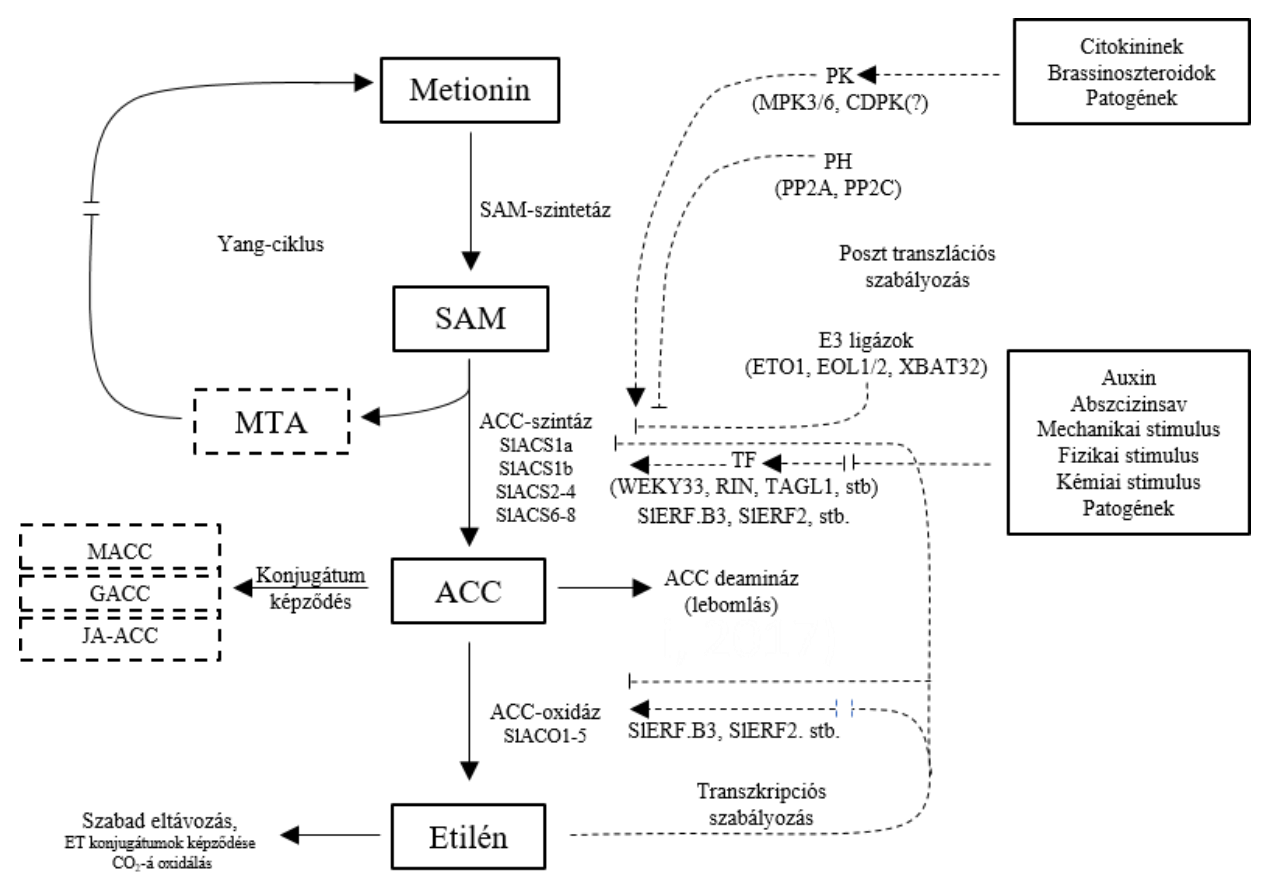

1. ábra Az ET bioszintézisének és szabályozásának általános modellje, kiegészítve néhány paradicsom-specifikus elemmel [10-15]. PK: proteinkinázok; PH: protein foszfatázok; TF: transzkripciós faktorok; MACC: malonil-ACC; GACC: $\gamma$-glutamil-ACC; JA-ACC: jazmonoil-ACC.

Az ACC-szintáz (ACS) által katalizált reakcióban képződik az ET közvetlen prekurzora, az 1-aminociklopropán-1-karbonsav (ACC). E folyamat mellékterméke az 5 '-metiltioadenozin (MTA), mely a Yang-ciklusba belépve végső soron újra metioninná alakul, ami egy kénmegtartó mechanizmus. Paradicsomban legalább nyolc ACS gén található. Kináz-foszforilációs helyeik alapján három csoportba sorolhatók, az 1-es csoport (SlACS1a, SlACS1b, SlACS2, SlACS6) mitogén aktivált- (MAPK) és ciklin-függő protein kinázok (CDPK) által foszforilálható helyekkel is rendelkezik, a 2-es csoportban (SlACS3, SlACS7, SlACS8) csak CDPK helyek fordulnak elő, míg a 3-as csoportban (SIACS4) nem találhatóak az említett kinázok számára foszforilációs pontok [11]. Az ACS katalizált ACC képződés az ET bioszintézis fö sebesség-limitáló lépése. A szabályozás egyrészt az ACS gének transzkripciójának szintjén történik, melyek csak indukáló faktorok jelenlétében expresszálódnak, másrészt az enzim stabilitásának poszttranszlációs kontrolljától függ (1. ábra), amit az enzim fél életidejét megnövelő foszforiláció is szabályoz.

A multigén családok által kódolt ACS expresszióját számos külső és belső környezeti tényező szabályozza, mint például a hormonális faktorok (auxinok, citokininek, brasszinoszteroidok), ontogenetikus szignálok, mechanikai, kémiai és fizikai stimulusok, valamint a növényi patogének. Alacsony ET szint mellett, normál körülmények között az ACS ubiquitin-függő lebomlása fontos poszttranszlációs regulátor szereppel bír. A szóban forgó folyamat az E3 ligázok által katalizált, mint például az ETO1, EOL1/2 (ETHYLENE OVERPRODUCER 1; ETO1 LIKE -1/2), melyek ritka kivétellel az ACS C-terminális 
doménjével lépnek kapcsolatba. Minden izoenzimnek megvan a maga E3 ligáz partnere, melyeken kívül MAPK-ok, CDPK-ok, foszfatázok, illetve bizonyos transzkripciós faktorok például paradicsomban a RIN (RIPENING-INHIBITOR) vagy a TAGL1 (TOMATO AGAMOUS-LIKE1) - is közvetíthetik a környezeti ingereket, illetve az ET által kiváltott visszacsatolási szignált is az ACS felé (1. ábra) [15]. A vegetatív növekedés során, az ET bioszintézist egy ET általi autoinhibitor rendszer szabályozza (I-es állapot), azonban, amikor több ET szükségeltetik - pl. szeneszcencia vagy a gyümölcsérés során - saját képződését az ET egy pozitív visszacsatolási körben serkenti (II-es állapot) [11].

A közvetlen ET felszabadulás az ACC oxidációjának az eredménye, melyet az ACCoxidáz (ACO) enzim végez. Jelentősen megemelkedett ET képződés mellett az ACO válik az ET bioszintézis kulcs-szabályozójává. Az ACO izoenzimeket kódoló multigén család expresszióját maga az ET szabályozza transzkripcionális szinten, illetve poszttranszlációs befolyásolásuk is feltételezett in silico analízis alapján [15]. Paradicsomban eddig öt ACO izoenzimet írtak le (S1ACO1-5), melyek génjeiben egyedi 5' és 3' nem transzlálódó régiók találhatóak, azonban mindegyikük transzkripcionálisan aktív [14]. A szabad ACC pool mennyiségét a szövetekben az ACC konjugátumok (malonil-, $\gamma$-glutamil-, és jazmonoil-ACC) képződése is befolyásolja [15]. Az ACC lebontása a növényekben az ACC-deamináz (ACD) által is lehetséges, ami szintén szabályozhatja az elérhető ACC, és végső soron az ET mennyiségét [12]. Habár a növényi szövetekben az ET metatabolizmus megvalósulhat a hormon $\mathrm{CO}_{2}$-dá oxidálásával, illetve az ET-oxid vagy ET-glikol konjugátumok képződése révén, valamint az utóbbi glükózzal való kapcsolódása is az ET bomlástermékek közé sorolható [10], a hormon legtöbbször csupán diffúzióval távozik a külső környezetbe [15]. Az ET diffúzióval halad sejtről sejtre is, azonban távolabbi ET válaszok kialakítása is lehetséges az ACC gyökér-hajtás vagy fordított irányú transzportja által [16]. Az ACC szállítását feltételezhetően a nempoláris aminosavak transzporterei végzik, mint például a LHT1 (LYSINE HISTIDINE TRANSPORTER1) lúdfüben [17].

Az ET jelátvitel általános modelljének a paradicsomra jellemző komponensekkel kiegészített folyamatát a 2. ábra foglalja össze. Az ET percepcióért felelős receptorok nagy hasonlóságot mutatnak a bakteriális két-komponensü szabályozó rendszerekkel. Ezek az integrált, homo és heterodimert formáló membránfehérjék az endoplazmatikus retikulumban (ER) - ill. feltehetőleg a Golgi apparátusban - lokalizáltak és ET hiányában a szignalizáció negatív szabályozói [18, 19]. Preferenciális vagy véletlen módon kialakított klaszterben funkcionálnak és együttmüködve kontrollálják a szignalizációt [20]. Három fő doménjük a szenzor, a kináz és a válaszregulátor domén. Az $\mathrm{N}$ terminálison elhelyezkedő szenzor domén a 
felelős az ET-érzékelésért, a dimerizációért és az RTE1 kofaktor kötődésért. Az itt történő mutációk képtelenné teszik a receptort az ET kötésre, mely ET-inszenzitív fenotípust eredményez [21]. A kináz domén katalizálja a hisztidin csoport adenozin-trifoszfát (ATP)függő autofoszforilációját. A hisztidinhez kapcsolt foszfát csoportnak a válaszregulátor domén aszparaginsav csoportjára történő átvitele a régió aktiválását eredményezi. Paradicsomban jelenleg hét ET receptort írtak le, ezek az SIETR1, -2, -4, -5, -6, -7 és a NEVER RIPE (NR) $[18,21]$. A hetedik receptor, az SIETR7 létezését a közelmúltban validálták filogenetikus analízis segítségével [23]. Az SIETR3-ra történeti okokból NR-ként hivatkoznak a szakirodalomban [24]. Három ET receptor, az SIETR1, -2 és a NR az I-es receptor alcsaládba tartozik, mivel rendelkeznek jól konzervált hisztidin-kináz (His-kináz) doménnel. A másik négy receptor (SlETR4-SIETR7) a II-es alcsaládba sorolandó, mivel egyes, a His-kináz aktivitáshoz szükséges alkotóelemeik hiányoznak, ennek ellenére azonban részt vesznek a jelátvitelben [23]. A paradicsom ET receptorok a legtöbb szövetben expresszálódnak, azonban kifejeződési mintázatuk a fejlődési állapot, illetve különféle környezeti stimulusok függvénye. [18]. Közülük kettő, az SlETR1 és az SlETR2 konstans módon expresszálódik a növényi szövetekben az egyedfejlődés során. Az SlETR4 gén kifejeződése felülszabályozódik a gyümölcsérés, a szeneszcencia és a levélhullás során, míg az SIETR5 a gyümölcsben és a virágban expresszálódik, illetve patogén fertőzés során is aktiválódik [22].

A $N r$ egy domináns mutáció a gén $\mathrm{N}$-terminális régióján, ami befejezetlen és késleltetett érési fenotípust és narancssárga színü, csekély mértékben puhult paradicsomgyümölcsöket eredményez, a receptor ET kötésének sérülése miatt [25]. A $N r$ expressziója megfigyelhető a gyümölcs perikarpiumában [26], azonban a paradicsomrügy és -levél szöveteiben is [27]. A vegetatív szervekben is aktív $N r$ mutáció ET inszenzivitást vált ki az összes vizsgált szövetben. Míg a termésben a mutáció domináns jellegű, vagyis a termésérés az $N r / n r$ heterozigótáknál is elmarad, a vegetatív szövetekben a gén szemidomináns jellemzőkkel rendelkezik. A homozigóta domináns $\mathrm{Nr} / \mathrm{Nr}$ mutánsok csaknem teljesen érzéketlenek az ET-re a hármas-válasz próba során, a petiolumok epinasztiás válaszában, a virágok szeneszcenciájában és lehullásában. Ezzel szemben a $N r$ mutációra heterozigóta növények $(N r / n r)$ csökkent intenzitású hármas-választ mutatnak exogén ACC jelenlétében. A $N r$ mutánsokban a levél szeneszcenciájának késleltetését is megfigyelték [28]. 


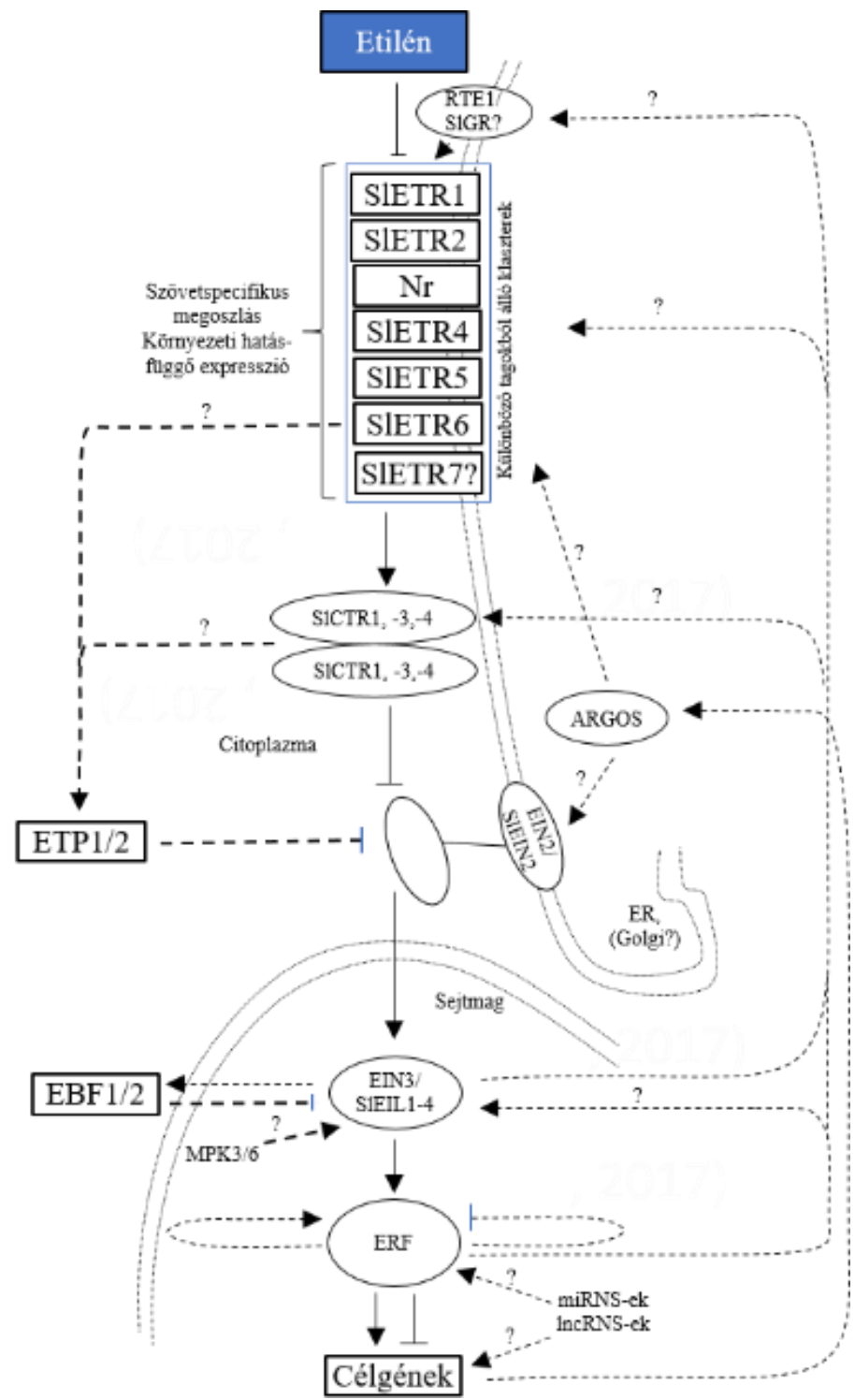

2. ábra Az ET jelátvitelének és szabályozásának egyszerúsített modellje, kiegészítve néhány paradicsom specifikus elemmel. A lineáris útvonalat a szimpla vonalak jelzik; a fehérjék stabilitásának poszttranszlációs szabályozását a vastag, szaggatott vonalak mutatják; a visszacsatolási hurkokat a szimpla, szaggatott vonalak indikálják; a kérdőjelek potenciális szabályozási interakciókat feltételeznek [3, 15, 18, 20, 22, 23, 26, 27, 29, 30-35].

Mindazonáltal, a Solanum lycopersicum cv. Ailsa Craig háttérü $\mathrm{Nr} / \mathrm{Nr}$ mutánsok, rendelkeznek egy jelentősen csökkent, reziduális, exogén ET-érzékenységgel a hármas-válasz tesztben. A hipokotiljaik megnyúlása az exogén ET 1 ppm-es koncentrációra jelentősen csökkent mértékben, de reagál, azonban 1000 ppm ET hatására is csupán a vad típusú (VT) válasz töredékét mutatja. Továbbá, a $N r / N r$ mutáns gyökerek megnyúlása csaknem teljesen inszenzitív az ET-re. A S. lycopersicum cv. Ailsa Craig háttérü $N r / N r$ mutáció nagymértékü csökkenést okoz az ET-érzékelésben és a fennmaradó, reziduális szenzitivitás a fiziológiailag releváns ET koncentrációk esetében marginálisnak tekinthető [36].

Az ET a receptorok három transzmembrán doménjéhez kötődik réz kofaktor jelenlétében. A réz(I) ion a Golgiba a RAN1 réz-transzporter közremüködésével jut be, majd az ET receptorfehérje érése során kötődik az apoproteinhez [37, 38]. Az RTE1 (REVERSION 
TO ETHYLENE SENSITIVITY1) membránfehérje túltermeltetése stabilizálja az ETR1 receptort lúdfüben és az egész növényre kiterjedö ET inszenzivitást vált ki, akár magas ET koncentráció jelenlétében is. Paradicsomban fellelhető homológja, a GR (GREEN RIPE) fehérje viszont a gyümölcsérést késlelteti [20].

A soron következő szignalizációs komponens, az ugyancsak negatív szabályozó, Rafszerü szerin/treonin kináz, a CTR (CONSTITUTIVE TRIPLE RESPONSE), melyből paradicsomban, ellentétben a lúdfüvel, több homológ is vehet részt az ET jelátvitelben [31]. Élesztő két-hibrid rendszerben interakciót mutattak ki az S1CTR1-es, 3-mas és 4-es izoformák és az I-es családba tartozó paradicsom ET receptorok között, továbbá hagyma epidermiszben koexpresszált NR receptor és a felsorolt SICTR izoformák között is in vivo [30], míg az SlCTR2 csak az SIETR1 és -2 receptorokkal hat kölcsön, bár ennek in vivo szerepét még nem tisztázták. Az SICTR3 teljesen komplementálta az lúdfü ctr 1-8 mutációt, míg az S1CTR1 és S1CTR4 csak részben. Az SlCTR1 expresszió gyorsan válaszol az exogén ET jelenlétére, míg az SlCTR2, -3, -4 és az utóbbi splice variánsainak (SlCTR4svl és -2) mRNS szintjei nem változtak szignifikánsan [39]. A CTR-szerü fehérjék C-terminális doménjének szekvenciája nagymértékü homológiát mutat a lúdfüben megtalálható ortológjukkal, míg N-terminális régiójuk kevésbé hasonló (<50\%) az AtCTR1 szekvenciához, viszont az itt található CN-box konzervált az összes SlCTR típusban. Továbbá a paradicsom CTR gének kifejeződési mintázata eltérő, szemben a lúdfüben található, konstitutívan expresszálódó AtCTR1-gyel [31]. Az SITPR1 (TETRATRICOPEPTIDE REPEAT 1) feltételezhetően kötődik az SIETR1-hez és a NR-hoz, vagy a CTR-szerü fehérjék kötődésével interferál, illetve a receptorok lebontását segíti [21].

ET hiányában a CTR foszforilálja az EIN2 (ETHYLENE INSENSITIVE2) pozitív szabályozó, a Golgi membránhoz kötött fehérjét. A paradicsomban leírt EIN2 homológ, az SlEIN2 expressziója különböző mértékü az eltérő fejlődési stádiumokban a paradicsomlevelekben és gyümölcsben [29]. A hormon receptorhoz kötődése gátolja a CTR1t, ezért az EIN2 foszforilálatlan, C-terminális doménje lehasad, majd a sejtmagba transzlokálódik és aktiválja az EIN3/EIL (ETHYLENE INSENSITIVE3/EIN3 LIKE) transzkripciós faktorokat, illetve az ET válaszelemeket (ERF; ETHYLENE RESPONSE FACTOR) [40]. Az MPK3 és az MPK6 proteinkinázok foszforilácó útján hatnak az EIN3 stabilitására, továbbá az EIN2 és EIN3/EIL fehérjék mennyisége ubiquitináció és proteaszomális lebomlás útján is szabályozott, előbbi az ETP1 és -2 (EIN2 TARGETING PROTEIN1, -2), utóbbiak pedig az EBF1 és -2 (ETHYLENE BINDING F-BOX PROTEIN 1, -2) F-box fehérjék által [15, 21]. Paradicsomban négy EIL gént izoláltak, melyek az Sl-EIL1, Sl-EIL2, Sl-EIL3, Sl-EIL4 neveket kapták [32]. Az EIN3/EIL transzkripciós faktorok 
visszacsatolással szabályozhatják a CTR1, RTE1 és az ET receptorokat kódoló géneket lúdfüben [15].

Az ERF-ek rendelkeznek egy 58-59 aminosavból álló, konzervált AP2 (APETALA2) doménnel, melynek segítségével számos cisz-ható elemhez kötődnek az ET-indukálta gének promótereiben. Az ERF család két alcsaládból tevődik össze, nevezetesen a CBF/DREB (CREPEAT BINDING FACTOR/DEHYDRATION RESPONSIVE ELEMENT BINDING FACTOR) alcsaládból, mely az etilén válaszgének DRE/CRT (DEHYDRATION RESPONSIVE ELEMENT/C-REPEAT) elemeihez kötődnek, illetve az ET-indukált promóterekben található GCC-boxokhoz kötődő ERF-ek alcsaládjából. Paradicsomban 9 további alcsoportba rendszerezett, 77 ERF alcsaládba tartozó gént azonosítottak, míg a DREB alcsaládba eddig 48 gént soroltak. A CBF/DREB alcsaládban valin és glutaminsav található az AP2 domén 14-es és 19-es pozíciójában, míg az alanin és az aszparaginsav konzervált az ERF alcsalád megfelelő pozícióiban [41]. Az ERF transzkripciós faktorok rendszerezhetők a célgénekre kifejtett gátló, vagy indukáló hatásuk alapján is [42]. Zhang és munkatársai [13] korábban kimutatták, hogy az SIERF2 részt vesz a paradicsom ACS és ACO gének expressziójának kontrolljában (1. ábra). A SlERF.B3 paradicsom ERF képes szabályozni az ACS és ACO enzimek, valamint az SIETR6 receptor expresszióját, továbbá befolyásolja az elsődleges ET transzkripciós faktorok (SIEIL) és számos más ERF expresszióját is (1. és 2. ábra), ami jó példája az ET saját bioszintézisének visszacsatolásos szabályozására, továbbá az ERF-ek egymást is szabályozhatják. Az ERF-ek feltételezhetően egy olyan szabályozó hálózat tagjai, melyben transzkripciós faktorok versengenek a promóterekért, hogy kontrollálják az ET válaszgének expresszióját [32].

Az ET hatás időben és térben szabályozott, csupán érzékennyé tett szövetekben és sejtekben okoz változást [3]. A szövetekben jelenlévő receptorok mennyisége és az ETérzékenység között fordított arányosság áll fent. Minél több ET receptor található az adott sejtben, annál több ET szükséges a jelátviteli gátlás feloldásához és fordítva. Fontos megjegyezni továbbá, hogy a receptorok általi ET-kötés hosszú féléletidejű (több mint 12 óra), így az „inaktivált” receptor nagyon hosszú ideig - vagy akár véglegesen - képtelen lesz elnyomni az ET-indukált géneket [43]. Egyes hipotézisek alapján, az ET-t kötött receptor inaktiválja a klaszterben lévő többi receptort is, mely magyarázhatja, hogy a növények nagyon alacsony ET koncentrációt is érzékelnek. Azonban a szövetek nagyon széles koncentrációtartományban képesek érzékelni az ET-t, amit az említett teória nem magyaráz. A klaszterbéli receptorok közti kooperáció meghatározza a jel erősségét. Az erős pozitív együttmüködés erős ET receptor jelátvitelt közvetít, míg a gyenge vagy negatív kooperáció gyenge 
szignáltranszdukciót eredményez. Ennél fogva, a változatos receptor csoportok a sejten belül képesek egy gyengétől-erősig terjedő receptor szignálgradienst létrehozni, így a növény széles ET koncentráció tartományra képes válaszolni. A klaszter összetételének megváltoztatásával melyet maga az ET is képes indukálni - az elfojtott konstitutív ET válasz annak tükrében fog módosulni. A szöveti deszenzitizáció egyik legfontosabb eleme a ligand-asszociált receptorok lebontása, majd cseréje [20]. Az elérzéktelenítés folyamatában részt vehetnek az ARGOS (AUXIN REGULATED GENE INVOLVED IN ORGAN SIZE) géncsalád tagjai (2. ábra), melyek ET hatására indukálódnak, és az ER-ban lokalizált fehérjékként szabályozzák feltehetően a receptorokat és az EIN2 fehérjét [33]. Az SIETR1 miRNS-ek (mikro-RNS) általi szabályozását is kimutatták korábban, csakúgy, mint az ET-indukált transzkripciós faktorok esetében (2. ábra), mint például a MADs-box, F-box, AP2/EREBP vagy az AP2/ERF illetve számos ERF gén esetében [34]. Az utóbb felsorolt transzkripciós faktorok és gének további, ún. hosszú-nem-kódoló RNS-ek (lncRNS-ek) szabályozása alatt is állnak [35]. Az ET közvetítette szabályozás különbözhet az eltérő típusú abiotikus stresszfaktorok által [44], melyek közül az értekezés tárgyát 2.2.3. alfejezetben jellemzett a sóstressz folyamatai képezik.

\subsubsection{Az etilén szerepe a fotoszintézis szabályozásában}

A fotoszintézis alapvető résztvevője a növényi életnek, hiszen többek között redukált szénvázat és energiát szolgáltat a szénhidrátok, aminosavak és másodlagos anyagcseretermékek szintéziséhez és végső soron a növekedéshez, illetve a terméshozamhoz [45]. Az ET egyik legkevésbé kutatott hatása, a fotoszintézisre, illetve az azzal asszociált elemekre gyakorolt szabályozó szerepe [46]. Annak érdekében, hogy könnyebb legyen megérteni az ET szerepét ebben a folyamatban, fontos felelevenítenünk annak fontosabb lépéseit és szabályozó faktorait.

A fotoszintézis főbb lépéseit a 3. és 4. ábra foglalja össze. A tilakoidok kapcsolt régióiban található II-es fotokémiai rendszerben (PSII) a reakciócentrum P680 klorofill $a$ molekulája egy elektronját az abszorbeált fényenergia segítségével átadja az elsődleges elektronakceptor partnerének, a feofitinnek (Phe) majd a kinon A-nak $\left(\mathrm{Q}_{\mathrm{A}}\right)$, majd az elektron a víz bontásából pótlódik. A sztrómatilakoidokban lokalizált I-es fotokémiai rendszerben (PSI) a P700 reakciócentrum klorofill $a$ speciális pár és az $\mathrm{A}_{0}$ molekula közt megy végbe töltésszétválasztás. A $\mathrm{P} 700^{+}$közvetlen elektron donor molekulája a plasztocianin [45]. Ezt követően, elektronáramlás alakul ki a két fotokémiai rendszer, illetve a PSI és a terminális elektronakceptora, a NADP ${ }^{+}$között a lineáris elektrontranszport (LET) során (4. ábra).

A PSII-ből az elektronok a plasztokinon (PQ) pool-ba, majd a Citokróm b//f komplexbe jutnak, ahonnan a már említett plasztocianin továbbítja őket a PSI-be. A PSI ből a ferredoxinra $(\mathrm{Fd})$, majd a ferredoxin-NADP ${ }^{+}$-oxidoreduktáz (FNR) által a $\mathrm{NADP}^{+}$-ra kerül az elektron, 
melynek eredményeképpen NADPH képződik (4. ábra). A folyamat során transztilakoid $\mathrm{H}^{+}$ áramlás és elektromos potenciál gradiens $(\Delta \mathrm{pH}$ és $\Delta \mathrm{E})$ is kialakul a tilakoid lumen és a kloroplasztisz sztróma között, melyet az ATP-szintáz enzim ATP képzésre használ fel [45].

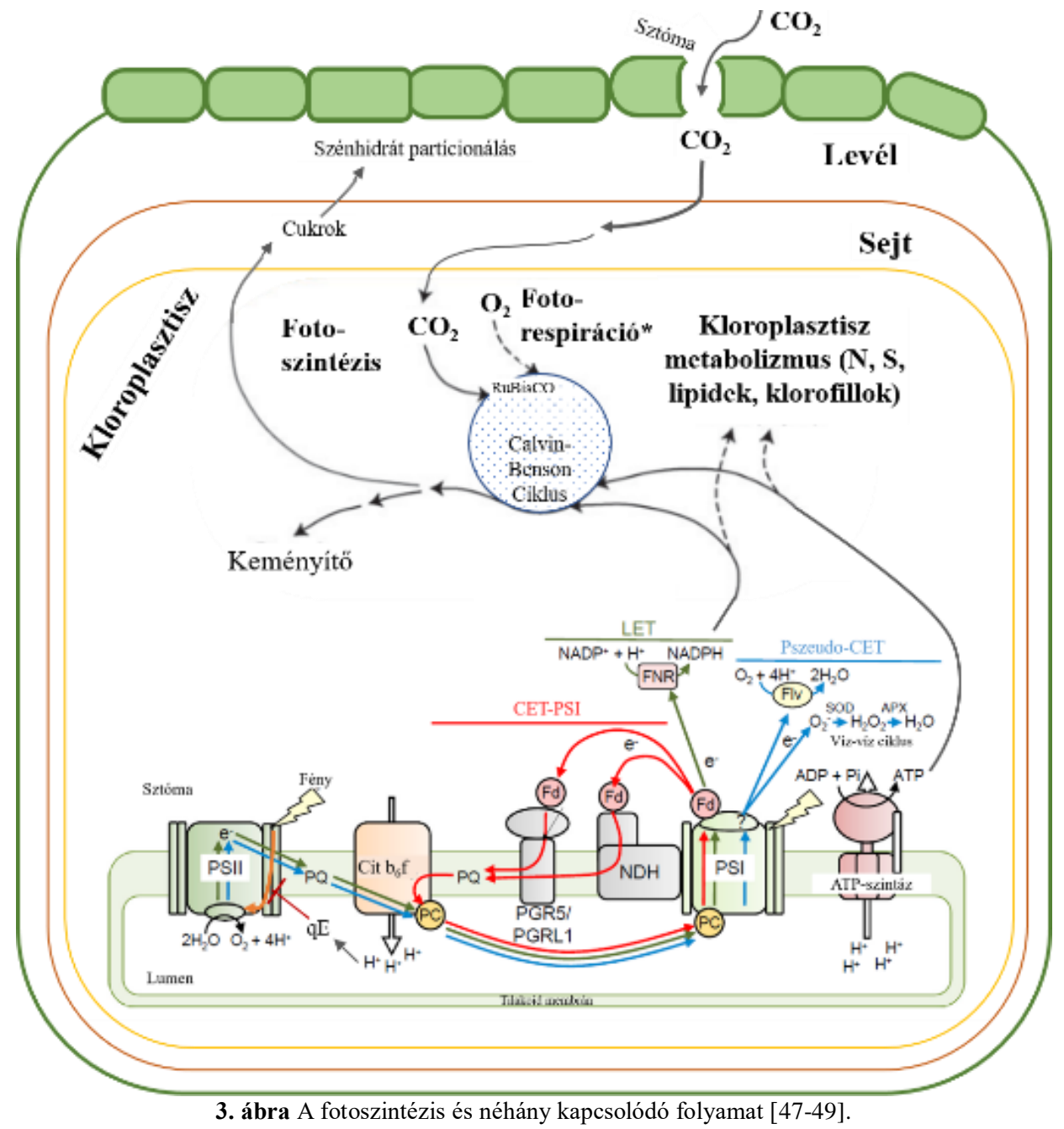

A folyamat szerves része a PSI körüli ciklikus elektrontranszport (CET-PSI), mely optimális körülmények között is - bár nem domináns mértékben - hozzájárul a fotoszintézis során képződött ATP mennyiségéhez. A CET-PSI során az elektronok a Fd-ról a Citokróm b6/f komplex közvetítésével PQ-pool-ba, majd a Citokróm b6/f komplexen keresztül újra a PSI-be vándorolnak, mellyel hozzájárulnak a $\Delta \mathrm{pH}$ kialakulásához nettó NADPH képződés nélkül. Zárvatermő növényekben eddig két CET-PSI útvonalat írtak le, melyek közül a főbb a PGR5/PGRL1 (PROTON GRADIENT REGULATION5/PGR5-LIKE PHOTOSYNTHETIC PHENOTYPE 1) komplex által mediált, míg a másik kloroplasztisz NDH-függő út (NADH DEHYDROGENASE-LIKE), mely szuperkomplexet alkot a PSI-el (4. ábra) [49].

A gázcserenyílásokon keresztül bejutott $\mathrm{CO}_{2}$ megkötése és redukciója a Calvin-Benson ciklus (CBC) során, a kloroplasztisz sztrómában történik (4. ábra). $\mathrm{C}_{3}$-as növényekben a 
Ribulóz-1,5-biszfoszfát-karboxiláz-oxigenáz (RuBisCO) enzim katalizálja a ribulóz-1,5biszfoszfát és a $\mathrm{CO}_{2}$ reakcióját, melyet egy redukciós, majd regenerációs lépések követnek [48].

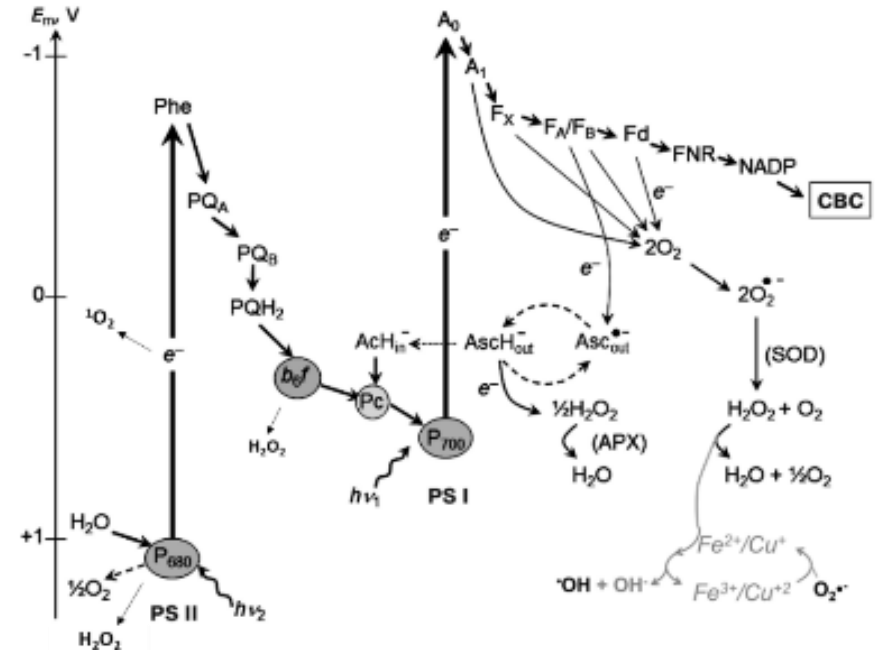

4. ábra A fotoszintézis lineáris elektrontranszportja és a ROF képződés/kioltás főbb résztvevői. Cherepanov és mtsai. [45] ábrája kiegészítve Roach és Krieger-Liszkay [48] nyomán. $\mathrm{PQ}_{\mathrm{B}}$ : kinon $\mathrm{B}, \mathrm{A}_{0}$ : A P700 elsődleges elektronakceptora, $\mathrm{A}_{1}$ : fillokinon, $\mathrm{F}_{\mathrm{X}}, \mathrm{F}_{\mathrm{A}}$, $\mathrm{F}_{\mathrm{B}}$ : vas-kén klaszterek, AscH': aszkorbinsav anion (teljesen redukált állapot), Asc ${ }^{\bullet}$ : monodehidroaszkorbát.

Mivel a fénybegyüjtő antennák hatékonysága elég magas, a fotoszintetikus fotonáramsűrüség (PPFD) különböző okokból túllépheti a fotoszintetikus kapacitást és fényindukált károsodást, fotoinhibíciót okoz. Fontos megjegyezni, hogy a kedvezőtlen környezeti körülmények között az alacsonyabb intenzitású fény is túltelítheti a rendszert és a reaktív oxigén formák (ROF) - mint a szinglet-oxigén $\left({ }^{1} \mathrm{O}_{2}\right)$, szuperoxid-gyök anion $\mathrm{O}_{2}{ }^{\bullet-}$, a hidrogén peroxid $\left(\mathrm{H}_{2} \mathrm{O}_{2}\right)$ vagy a hidroxil-gyök (HO') fokozott akkumulációját eredményezheti, melyek károsíthatják a tilakoidmembránokat és a fotokémiai rendszereket. A rendkívül reaktív ${ }^{1} \mathrm{O}_{2} \mathrm{a}$ PSII-ben lejátszódó, töltés-rekombinációs reakciók során keletkezhet. A CET-PSI mellett egy másik alternatív elektrontranszfer folyamat a pszeudo-ciklikus elektron-transzport (pszeudoCET), ahol az elektron a Fd-ról a molekuláris oxigénre kerül és $\mathrm{O}_{2}{ }^{\bullet-}$ képződik [49]. A PSI akceptor oldala a $\mathrm{O}_{2}{ }^{--}$legfőbb forrása a folyamatban. $\mathrm{A}_{2} \mathrm{O}_{2}$ reakciója $\mathrm{Cu}^{+}$vagy $\mathrm{Fe}^{2+}$ ionokkal a szintén nagyon reaktív $\mathrm{HO}^{\bullet}$ képződését eredményezheti, továbbá a $\mathrm{Fe}^{3+} / \mathrm{Cu}^{2+}$ visszaalakulhat $\mathrm{Fe}^{2+} / \mathrm{Cu}^{+}$ionnná a $\mathrm{O}_{2}{ }^{\bullet-}$ által. Kisebb mennyiségben az elektrontranszport más pontjain is keletkezhetnek reaktív molekulák (4. ábra) [48].

$\mathrm{A} \mathrm{O}_{2}{ }^{--}$-ból, protonok felvételével a szuperoxid-dizmutáz (SOD, EC 1.15.1.1) enzim által a kevésbé reaktív $\mathrm{H}_{2} \mathrm{O}_{2}$ jön létre, melyet az aszkorbát-peroxidáz (APX, EC 1.11.1.11) vagy peroxiredoxin (PRX, 1.11.1.15) enzimek alakítanak vízzé. Az antioxidáns rendszer elfogyasztja a fotoszintézis által létrehozott redukáló ekvivalenseket, a Fd-t és a NADPH-t az aszkorbát regenerációjához (4. ábra) [49]. A SOD izoenzimek közül jellemzően a Fe (Fe-SOD) vagy a $\mathrm{Cu}$ és $\mathrm{Zn}(\mathrm{Cu} / \mathrm{Zn}-\mathrm{SOD})$ kofaktorral rendelkezők vesznek részt a folyamatban. Az APX aszkorbinsavat igényel, a PRX aktivitás pedig a tioredoxinok újra-redukálódásától függ. 
További más antioxidáns aktivitású enzimek és molekulák is részt vesznek a fotoszintéziskapcsolt ROF kioltásában. Bár a PSII sokkal sebezhetőbbnek tünik a ROF okozta károsodásokkal szemben, rendkívül hatékony javító mechanizmusainak hála a hatás - egészen addig, míg a kár mértéke a kapacitásukat túl nem haladja - csupán átmeneti. A PSI ROF általi (leginkább $\mathrm{O}_{2}{ }^{\bullet}$ ) károsodása, bár kevésbé gyakori, bekövetkezése esetén tartósan kivonja a müködés alól ezt a fotokémiai rendszert, hiszen turnovere rendkívül lassú. A PSII érzékenysége ennélfogva fontos szabályozó mechanizmusa az elektrontranszfer folyamatoknak [48]. Ezen túlmenően, az oxidatív módosítások hatnak a RuBisCO fehérje mennyiségére is $[50,51]$.

Egyéb befolyásoló elemek mellett az elektrontranszport gyorsan reagáló, talán legjelentősebb szabályozását a nem-fotokémiai kioltások (NPQ) közül - nevét a klorofill $a$ fluoreszcencia nem fotokémiai úton történő kioltásáról kapta, bővebb magyarázat Kalaji és munkatársai [52, 53] munkáiban - a $\Delta \mathrm{pH}$-függő NPQ, a qE végzi (3. ábra). A lumensavanyodás következtében PsbS és az LhcSR3 fehérjék luminális részei és a fénybegyüjtő komplexek protonálódnak, illetve aktiválódik a xantofill-ciklus, mely zeaxantin képződésével jár, ami a PsbS fehérjéhez - valamint az LHCII-höz és egyéb LHC fehérjékhez - kötődve képes kioltani a gerjesztett klorofillokat. Így az excitációs energia hő formájában disszipálódik, mielőtt elérné a reakciócentrumot $[48,54]$. További qE mechanizmus az LHCII PSII-ről történő leválását követő aggregálódása, mely zeaxatin és csapdázott protonoktól függő módon egy lassan relaxálódó NPQ folyamatért felel [55]. A $\Delta \mathrm{pH}$-függő NPQ-nak fontos szabályozója/indukálója a CET-PSI, mivel nagyban hozzájárul a lumen savanyodásához. Továbbá, a luminális pH csökkenése lassítja a Citokróm $\mathrm{b}_{6} / \mathrm{f}$ komplex és a vízbontó komplex aktivitását, valamint a $\mathrm{P} 680^{+}$redukciós kinetikáját. Fontos megfigyelés volt, hogy pH 5,2 alatt a vízbontó komplex reverzibilisen inaktiválódik. Mindezek tükrében könnyen megérthető, hogy míg normál körülmények között a LET müködése dominál, kedvezőtlen környezeti körülmények között a mikor a $\mathrm{CO}_{2}$ mennyisége vagy hasznosítási folyamata limitált - nagyobb hangsúlyt kapnak az alternatív elektrontranszport folyamatok, mint a CET-PSI vagy a pszeudo-CET, hogy kifejthessék szabályozó funkcióikat [48].

A CBC-ből a széndioxid-fixációból származó trióz-foszfátok folyamatos elvonása is szükséges, mely a kloroplasztikus keményítő raktározáson keresztül és/vagy a citoszolba történő exportálásuk során valósul meg. Ez utóbbi esetben szacharóz szintetizálódik belőlük, mellyel a növény a nem-fotoszintetizáló részeit táplálja. Hatékony szacharóz transzport szükséges a szénhidrátok felhasználóhelyekre történő szállításához, illetve a változó környezeti tényezőkre adott megfelelő válaszok kialakításához a növényekben [56]. 
A fotorespiráció jelensége, mely a RuBisCO oxigenáz aktivitásának az eredménye, a már megkötött $\mathrm{CO}_{2}$-ot szabadítja újra fel, továbbá ATP-t és redukáló ekvivalenseket fogyaszt. Maga a folyamat több sejtszerv együttmüködését igényli. Mivel elektronnyelő folyamat, megakadályozza az elektrontranszportlánc túlredukálódását és így a fotoinhibíciót, mely különösen stressz során jelentős [57]. A peroxiszómában lejátszódó lépéseken kívül - ahol intenzív $\mathrm{H}_{2} \mathrm{O}_{2}$ produkció megy végbe a reakciók során - a fotorespiráció a kloroplasztisz és a mitokondrium ROF státuszát is szabályozza [58].

Elsőként földimogyoró (Arachis hypogaea) levelekben figyelték meg, hogy az exogén ET gáz gátolja a fotoszintézist, azonban fontos megjegyezni, hogy a többféle koncentrációval történő, kétórás kezelések során, $0,1 \mu \mathrm{L}$ ET/L-es koncentráció alatt ez a jelenség nem volt megfigyelhető [59]. Ezzel szemben, Taylor és Gunderson [60] nem tapasztalt szignifikáns $\mathrm{CO}_{2}$ gázcsere gátlást, illetve sztómakonduktancia változást 4 órás, exogén $\mathrm{ET}$ gázzal kezelt paradicsomnövények esetében. Exogén, $300 \mathrm{mg} / \mathrm{L}$ koncentrációjú Ethephon - egy ET-t generáló vegyület - intakt paradicsomlevelekre permetezése csak a $\mathrm{CO}_{2}$ asszimilátumok szervek közötti megoszlását befolyásolta, a fotoszintézist nem [61]. Egyéb munkákat is összefoglalva azt a következtetést vonhatjuk le, hogy az exogén forrásból származó ET legtöbbször gáz vagy Ethephon - bizonyos fajokban gátolja, másokban nem befolyásolja a fotoszintetikus aktivitást stresszmentes körülmények között [62-65]. Ceusters és Van De Poel [46] munkája jól összefoglalja az irodalomban eddig fellelhető, vonatkozó eredményeket. De vajon valóban elkönyvelhetjük az ET fotoszintézisre gyakorolt hatását a leírtaknak megfelelőként? Vagy csupán a vizsgálatok ET koncentráció- és expozíciós idő, esetleg fejlődési állapot-függő felbontása nem volt elég alapos? Esetleg az ET forrás jellegétől - minősége és eredete - is függ a hatás? Eddig csak mustárban mutatták ki, hogy alacsonyabb exogén ET koncentrációk serkentik a fotoszintézist (a nagyobbak ott is gátló hatásúak) [66].

ET-inszenzitív mutánsok vizsgálata alapján elmondható, hogy az ET közvetlenül szabályozza a fotoszintézist fiatal/nem-szeneszcens levelekben és indirekt módon idősebb levelekben, elsősorban a szeneszcencia - például a klorofill lebomlás - befolyásolásával (5. ábra). Lúdfú ET-inszenzitív mutánsban (etrl-1) alacsonyabb klorofill tartalmat, RuBisCO aktivitást, illetve néhány fotoszintézis-asszociált gén represszióját figyelték meg. Továbbá, az etr1-1 és ein2 mutáns lúdfü, illetve ET inszenzitív dohány (Nicotiana tabacum) transzgénikus növények csökkent fotoszintetikus kapacitással rendelkeznek, föleg telítési fényintenzitásokon. További megfigyelések alapján egy optimális endogén ET szint állapot szükséges a növényben a normális klorofill tartalom kialakításához fiatal levelekben, míg a szeneszcenciára hajlamosakban az ellenkezője igaz [46]. Az exogén ACC, csakúgy, mint az Ethephon gátolta a 
sötétség és az abszcizinsav (ABA)-indukált sztómazárást Vicia faba zárósejtjeiben, valószínűleg a $\mathrm{H}_{2} \mathrm{O}_{2}$ kioltó rendszerek serkentésével. Továbbá, a két modulátor sztómanyitódást indukált sötétben [67, 68], utóbbiban szerepet játszhatott a nitrogén monoxid (NO) szint csökkenése is [69]. Ezzel szemben az ET gáz, az ACC és az Ethephon is sztómazárást váltott ki lúdfüben. Ugyanakkor, a megfelelő ET jelátvitel szükséges mind a normál sztómakonduktancia, mind a sztómaszám kialakulásához [46]. Az ET sztómazárást indukáló hatásának szignalizációja csupán részben ismert, viszont Arabidopsisban a receptoroktól downstream a heterotrimer G fehérje Ga alegységének (GPA1) aktiválódásával jár, mely serkenti az At-RBOH függő NADPH oxidázok müködését, így $\mathrm{H}_{2} \mathrm{O}_{2}$ képződést [70].

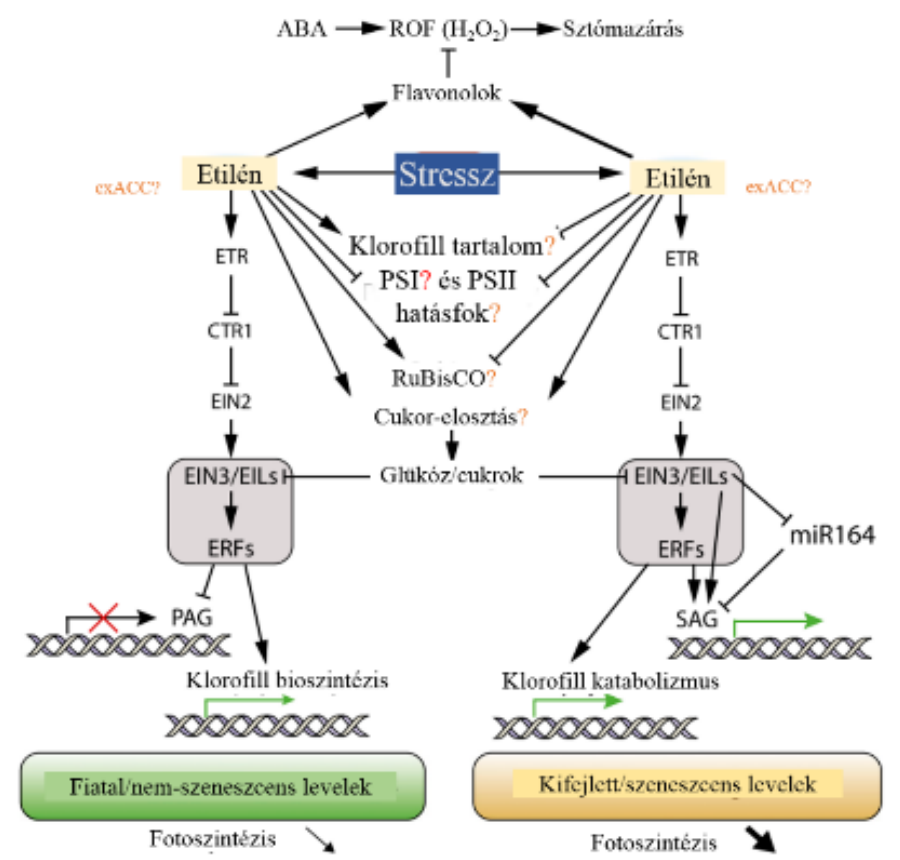

5. ábra Az ET hatása a fotoszintézisre és a kapcsolódó folyamatokra [46]. exACC: exogén ACC. A piros „?” bizonytalan hatást, a narancssárga ,?” az exogén ACC-vel kapcsolatos hiányos ismereteket jelzi, melyet bővebben a 2.1.4-es alfejezet tárgyal

4 órás ET expozíció 30\%-os csökkenést okozott a szója levelek fotoszintetikus elektrontranszport kapacitásában Wullschleger és munkatársai [71] szerint. A CitERF13 tranziens overexpresszáltatása dohánylevelekben szignifikánsan csökkentette a PSI és a PSII kvantumhatásfokát telítési fényintenzitáson [72]. Viszont az etr1-1, ET-inszenzitív Arabidopsis mutáns is alacsonyabb PSII aktivitással rendelkezett. Továbbá, a megnövekedett ET-termelésü eto1-1 mutánsokban gátlódott az NPQ kifejlődése a violaxantin-deepoxidáz (VDE), a zeaxantin bioszintézis kulcseznimének csökkent aktivitása miatt [46]. Ezek szerint intakt ET-érzékelés és normál ET produkció szükséges a PSII optimális müködéséhez. Az exogén forrásból származó ET és a PSI aktivitásának kapcsolatáról eddig nincs fellelhető adat a szakirodalomban.

ET-inszenzitív (etr1-1) lúdfü fiatal leveleiben csökkent, míg az idősebb levelekben megemelkedett RuBisCO aktivitás figyeltek meg a VT növényhez viszonyítva [46]. Az ET szabályozza a szénhidrát háztartást is. A glükóz és ET szignalizáció között például kölcsönösen 
antagonista kapcsolat áll fenn. ET-inszenzitív növények hiperérzékenyek a glükózra, míg a konstitutív ET válasz mutáció ( $c t r l$ ) vagy az ET túltermelése (eto mutánsok vagy ACC kezelés) csökkent cukorérzékenységgel jár. Az ET kezelés befolyásolja a szacharóz szintézisért és transzportért felelős gének expresszióját is [46].

\subsubsection{Reaktív oxigén- és nitrogénformák a növényekben, kölcsönhatásuk az etilénnel}

A növényi sejtekben végbemenő aerob metabolizmus redox-kaszkádjainak müködése során elkerülhetetlen a folyamatos ROF képződés, melyek egyfelöl folyamatos antioxidáns kontroll alatt tartása alapvető szükséglete a sejteknek - hiszen némelyikük komoly károkat tud okozni, - míg másfelől a növények használják a ROF-at vagy ROF-asszociált másodlagos bomlástermékeket (alkoxi vagy peroxi gyökök) a növényi életmüködés során. A ROF másodlagos hírvivőként funkcionálhat, mely módosítja bizonyos gének expresszióját, illetve specifikus fehérjék aktivitását a sejt redox-egyensúlyának megváltoztatásával. A ROF kölcsönhat több hormon szignalizációs elemeivel, illetve az indukált lipidperoxidáció termékei nemspecifikus jelmolekulákként is müködhetnek [73].

A ROF molekulák viszonylag rövid féléletidejüek, mind közül a legstabilabb a $\mathrm{H}_{2} \mathrm{O}_{2}$, melynek a többi molekulához viszonyítva kisebb a reaktivitása és membránokon is könnyedén keresztül juthat, így szignálmolekulaként is ideális. $\mathrm{A}_{2} \mathrm{O}_{2}$ keletkezhet a peroxiszómában a fotorespiráció során, a glioxiszómában, a kloroplasztiszban - a már ismertetett módokon - és a mitokondriális elektrontranszportlánc müködésekor, ez esetben elsősorban $\mathrm{O}_{2}{ }^{\bullet-}$-ból. A plazmamembránban a NADPH-oxidáz, az apoplasztban pH-függő sejtfal peroxidázok, a germin-szerü oxalát oxidázok és aminoxidázok is lehetnek a $\mathrm{H}_{2} \mathrm{O}_{2}$ forrásai [73]. A $\mathrm{H}_{2} \mathrm{O}_{2}$ diffúzióval a membránokon vagy az aquaporinokon halad keresztül [74].

A $\mathrm{O}_{2}{ }^{\bullet-}$ keletkezhet a fotoszintetikus és a légzési (I-es, II-es és III-as komplex) elektrontranszportláncok müködése, illetve a mikroszómális elektrontranszport során. Továbbá a sejtfal peroxidázok oxidálhatják a NADH-t $\mathrm{H}_{2} \mathrm{O}_{2}$ felhasználásával, mely során $\mathrm{O}_{2}{ }^{\bullet}$ keletkezik, ami azt követően $\mathrm{H}_{2} \mathrm{O}_{2}$-á dizmutálódik a SOD által. A két legreaktívabb szabadgyök, a ${ }^{1} \mathrm{O}_{2}$ és a $\mathrm{HO}^{\bullet}$ a mitokondriumban, a kloroplasztiszban és a sejt egyéb membránjaiban képződhet, és képesek lipidek, fehérjék és nukleinsavak oxidálására. Egyéb fontos ROF források a citoplazmában és az ER-ben található citokróm $\mathrm{P}_{450}$ által katalizált detoxifikáló reakciók [73]. Azonban a különböző ROF-generáló mechanizmusok hozzájárulása a sejtek ROF termeléséhez eltérö lehet [75].

A ROF szignalizáció a különbözö bomlástermékek mellett történhet közvetlenül a redox érzékeny transzkripciós faktorok módosításával is. A redox-szenzor proteinek - a cisztein és metionin aminosavakon - található aktív tiol-csoportokkal (-SH) rendelkeznek, melyek 
potenciális ROF célpontok. Oxidációt követően, a szenzorfehérjék kölcsönhatásba lépnek és oxidálják az effektor fehérjéket, feltehetően redox-relét alkotva. $\mathrm{A}_{2} \mathrm{O}_{2}$ metionin aminosavak -S- $\mathrm{CH}_{3}$ csoportjaival is reakcióba léphet, mely a legtöbbször inaktiválja a fehérjét, továbbá az érzékelő funkciót maguk az antioxidánsok is elláthatják [75].

A kloroplasztikus ROF termelés szorosan kapcsolódik a fény-függő fotoszintetikus reakciókkal, így az itt megemelkedett ROF akkumuláció jól jelzi a külső vagy belső körülmények megváltozását. Fotoszintetizáló szövetekben, a mitokondrium hozzájárulása a sejt ROF termeléséhez relatíve alacsony. A peroxiszomális $\mathrm{H}_{2} \mathrm{O}_{2}$ koncentráció szigorúan szabályozott a KAT által, így normál körülmények között nem haladhatja meg a $10 \mu \mathrm{M}-\mathrm{t}$ az organellumon belül. A peroxiszómában történő fotorespirációs $\mathrm{H}_{2} \mathrm{O}_{2}$ kioltás zavara fotorespirációt elősegítő körülmények között oxidáltabb irányba tolja el a sejt GSH és aszkorbát pool redox állapotát, mely a transzkriptóm gyors átalakulásához vezet. A peroxiszomális KAT aktivitás szükség esetén leszabályozódhat - például szalicilsav által - és ez lehetôvé teszi a tranziens $\mathrm{H}_{2} \mathrm{O}_{2}$ akkumulációt. Az apoplasztikus ROF a sejtorganellumokkal ellentétben ROF generáló enzimek müködése során keletkezik, mint a sejtfal peroxidázok, poliamin oxidázok, NADPH oxidázok vagy RBOH-k (RESPIRATORY BURST OXODASE HOMOLOG), az utóbbiak müködése kiemelten fontos a ROF szignalizácóban abiotikus stressz során. A levélben található $\mathrm{H}_{2} \mathrm{O}_{2}$ legnagyobb részt apoplasztikus eredetű [74].

Annak ellenére, hogy a ROF „,család” fontos szignálmolekuláknak is otthont ad, túlzott mértékủ akkumulációjuk túlterhelheti az antioxidáns rendszereket, ami oxidatív károsodáshoz és növekedésredukcióhoz vezethet a növényekben, melyet oxidatív stressznek nevezünk [48]. A ROF kezelés - föleg a $\mathrm{H}_{2} \mathrm{O}_{2}$ - képes stressztoleranciát kiváltani a növényekben, mivel aktiválhatja a védelmi folyamatokat. A $\mathrm{H}_{2} \mathrm{O}_{2}$ a PCD és a szeneszcencia egyik kulcsszabályozója, mely szignalizációs útvonalak aktiválásával indukálja a sejthalált. A sejthalált kiváltó oxidatív robbanás bekapcsolásakor elsőnek $\mathrm{O}_{2}{ }^{\bullet-}$ keletkezik. A legtöbb egyéb $\mathrm{ROF}$ a $\mathrm{O}_{2}{ }^{\bullet-}$ dizmutációja során, vagy azt követően jön létre. A ROF a növényi növekedés során is fontos szereppel bír [73].

A ROF-on kívül, a NO és származékai, mint például a peroxinitrit $\left(\mathrm{ONOO}^{-}\right)$, a dinitrogén trioxid $\left(\mathrm{N}_{2} \mathrm{O}_{3}\right)$, az S-nitrozoglutation (GSNO), a nitrogén dioxid $\left(\mathrm{NO}_{2}\right)$, a nitrozil kation $\left(\mathrm{NO}^{+}\right)$[76], S-nitrozotiolok ( $\left.\mathrm{SNO}\right)$, nitro-zsírsavak $\left(\mathrm{NO}_{2}-\mathrm{FA}\right)$ stb. - gyüjtőnevükön $\mathrm{RNF}$ - is kiemelt szereppel bírnak a növényi életfolyamatokban [77]. A NO gáz halmazállapotú növényi növekedésszabályozó molekula, mely fontos szerepet tölt be a fejlődés során, az abiotikus- és biotikus stresszválaszok kialakításában, beleértve a PCD-t is [78-80]. Életideje rövid, koncentrációjától is függően szignálmolekulaként vagy destruktív hatással rendelkezhet 
[80]. Az állatokkal ellentétben - ahol a NO L-argininből képződik a NO-szintáz (NOS) által növényekben a NO létrejöhet reduktív és oxidatív típusú enzimatikus reakciókkal [81-83], illetve nem-enzimatikus úton is. Növényekben eddig még nem találták meg az állati NOS homológ enzimet, azonban a NOS-aktivitást már kimutatták a peroxiszómákban, viszont a NO egyéb módokon képződhet a kloroplasztiszban és a mitokondriumban is [84]. A NO hatása főleg a származékai makromolekulákkal alkotott kölcsönhatásán keresztül valósul meg. Ezek közül a fehérje müködést módosító hatások a nitráció, az S-nitroziláció, ahol a NO kovalensen kötődik cisztein tiol csoportjaihoz és a metalloproteinek fémcentrumának nitrozilációja. A NO és a glutation reakciójából GSNO jön létre, mely fontos a hosszútávú NO szignalizációban [77].

A ROF túlzott akkumulációját az enzimatikus és a nem enzimatikus antioxidánsok tartják kordában. Utóbbiak közül a $\beta$-karotin antioxidáns hatásával képes kioltani a $\mathrm{HO}^{*}-\mathrm{t}$, a peroxil-gyököt és a $\mathrm{O}_{2}{ }^{-*}$-ot, valamint a glutation is kiemelt antioxidáns funkcióval bír. Az antioxidáns enzimek overexpresszáltatása (pl. KAT, SOD, APX) növelheti a toleranciát számos környezeti stresszel szemben [84]. A SOD három fő izoformája van jelen növényekben, melyek - fémion tartalmuk alapján megkülönböztetve - a mitokondriális és peroxiszomális elhelyezkedésű mangán SOD (MnSOD), a kloroplasztiszban található vas-SOD (FeSOD), illetve a citoplazmatikus, apoplasztikus és kloroplasztisz lokalizációjú réz/cink-SOD $(\mathrm{Cu} / \mathrm{ZnSOD})$ [85]. Paradicsomban eddig négy $C u / Z n S O D$, egy MnSOD és három FeSOD gént azonosítottak [86]. A MnSOD aktivitást nem gátolja a $\mathrm{H}_{2} \mathrm{O}_{2}$, míg a $\mathrm{Cu} / \mathrm{ZnSOD}$ és FeSOD müködését igen [87].

A KAT a $\mathrm{H}_{2} \mathrm{O}_{2}$-ra mM-os nagyságrendü szubsztrátaffinitással rendelkezik, ezért müködése stresszfolyamatok során válik jelentőssé [88]. A növényekben legtöbbször három izoformája található meg: KAT1, KAT2, KAT3, lokalizációjukat tekintve a glioxiszómákban és a peroxiszómákban (KAT1 és -2), a sejtfalban (KAT1 és -3) [89, 90]. A mitokondriális KAT3 előfordulását leírták spenótban és kukoricában is [91]. Szöveti kifejeződésük alapján ezek az enzimek további csoportokra oszthatók: az I. osztályba a fotoszintetizáló szövetekben előforduló, fényfüggő expresszióval rendeklező KAT enzimek tartoznak, mint például az Arabidopsisban a KAT2; a II. osztályba a vaszkuláris szövetekben lokalizált KAT enzimek (pl. a TOMKAT1 paradicsomban); a III: osztályba pedig a glioxiszómákban, leginkább fiatal növényekben és magvakban kifejeződő KAT enzimek sorolhatók [92]. Az APX, ahogy már említésre került, szintén részt vesz a $\mathrm{H}_{2} \mathrm{O}_{2}$ kioltásában, azonban elektrondonorként redukált aszkorbátot használ. Affinitása a $\mathrm{H}_{2} \mathrm{O}_{2}-\mathrm{hoz} \mu \mathrm{M}$-os nagyságrendü [88]. Paradicsomban három citoszolikus, két peroxiszomális és két kloroplasztikus lokalizációjú APX izoenzimet azonosítottak [93]. A kloroplasztikus APX szerepe korábban már említésre került, míg a 
citoszolikus izoenzimek általános védelmet nyújtanak stressz esetén. A mikroszómális APX-ek elsősorban a zsírsavak $\beta$ oxidációja során eliminálják a keletkező $\mathrm{H}_{2} \mathrm{O}_{2}$-dot [94]. A növényi peroxidázok ( $\mathrm{POD}, \mathrm{EC}$, 1.11.1.7.) a $\mathrm{H}_{2} \mathrm{O}_{2}$ lebontásához elektron donorként aromás vegyületeket, in vitro mérésük során leginkább gvajakolt vagy pirogallolt használnak. Megtalálhatóak a vakuolumban, citoszolban és a sejtfalban, de a sejtszervecskékben nem [88].

A ROF és az antioxidánsok között létrejövő egyensúlyhiány oxidatív stresszt okozhat, mely kialakulhat a túlzott ROF akkumuláció, illetve az antioxidánsok kioltó képességének csökkenése következtében egyaránt [84]. Mivel a ROF kölcsönhathatnak a RNF-kal, oxidatív mellett nitrozatív stressz is kialakulhat, melyet összefoglaló néven nitro-oxidatív stressznek nevezünk, amit számos abiotikus faktor, köztük a talaj magas sótartalma is kiválthat. A folyamat kialakulásában nagy szerepet játszik a NO képződése vagy elérhetősége, melyet a GSNO és az azt lebontó enzim, a GSNO reduktáz (GSNOR) valamint a ROF $\left(\mathrm{O}_{2}{ }^{\bullet-}\right.$ és $\left.\mathrm{H}_{2} \mathrm{O}_{2}\right)$ közötti egyensúly szabályoz [95]. A lúdfü APX1 S-nitrozilációja megnöveli az enzim $\mathrm{H}_{2} \mathrm{O}_{2}$ kioltó aktivitását és így növeli az oxidatív stresszel szembeni ellenállóképességet [96]. A nitráció egy nitro-csoport $\left(-\mathrm{NO}_{2}\right)$ hozzáadását jelenti a zsírsavakhoz, fehérjékhez vagy nukleinsavakhoz. Fehérjék esetében létre jöhet a tirozin, cisztein, metionin vagy triptofán aminosavakon, ami lehet hatástalan, okozhat funkciónyerést, vagy leggyakrabban funkcióvesztést. A $\mathrm{NO}$ és a $\mathrm{O}_{2}{ }^{--}$reakciójából létrejövő $\mathrm{ONOO}^{-}$által mediált nitráció a legtöbbször az utóbbi típusú hatást váltja ki, például néhány antioxidáns enzim, mint a KAT, vagy az APX stb. esetében. A $\mathrm{ONOO}^{-}$vezérelt tirozin nitráció nitrozatív stresszt válthat ki a sejtben, így ez a molekula jó markereke ennek a stressztípusnak. A PRX képes detoxifikálni a $\mathrm{ONOO}^{-}$-et, viszont aktivitását gátolhatja az S-nitroziláció, csakúgy, mint az RBOHD-t Arabidopsis-ban [77]. A ONOO- felhalmozódás csökkentheti a sejt $\mathrm{O}_{2}{ }^{\bullet-}$ tartalmát, így végső soron védheti a biomolekulákat az oxidációtól és megakadályozhatja a további ROF termelődést. A legújabb eredmények szerint, a $\mathrm{ONOO}^{-}$nem olyan toxikus növényekben, mint az állatokban. Továbbá, a $\mathrm{ONOO}^{-}$csökkentheti a $\mathrm{H}_{2} \mathrm{O}_{2}$ termelödését a SOD számos izoformájának blokkolása által [96].

Bár stressz során, mint a sóstressz [97, 98], vagy az ozmotikus stressz [99], számos tanulmány vizsgálta az ET és a ROF, illetve az ET és a RNF kapcsolatát, azonban stresszmentes körülmények között, néhány fejlődési folyamatot - például a szeneszcencia, a gyökérfejlődés, illetve az azzal asszociált PCD - és a sztómazárás szabályozását kivéve az ET és a szóban forgó reaktív molekulák szimultán vizsgált kölcsönhatásáról viszonylag keveset tudunk. Továbbá, a szakirodalomban fellelhető - specifikus stressz faktor jelenléte nélküli - vizsgálatok ritkán terjedtek ki a ROF és RNF, illetve az ET kapcsolatának, valamint az időbeni egymásra hatásuk 
egyidejü monitorozására. A növényi sejthalál különbözö típusaiban az ET és a ROF kölcsönhatása alapvető. Az exogén Ethephon kezelés $\mathrm{H}_{2} \mathrm{O}_{2}$ akkumulációt és szeneszcenciát indukált édesburgonya-levelekben [100]. A rizs mellékgyökér primordium képződését megelőző, ET-indukált epidermális sejthalál során a $\mathrm{H}_{2} \mathrm{O}_{2}$ downstream hatott az ET-től és függött a $\mathrm{O}_{2}{ }^{*-}$ termelő NADPH-oxidáz aktivitástól, továbbá az ET és a $\mathrm{H}_{2} \mathrm{O}_{2}$ egymást amplifikáló szignálként funkcionált a folyamat során [101]. A $\mathrm{H}_{2} \mathrm{O}_{2}$ akkumuláció stimulálta az ACO expressziót és az ET bioszintézisét transzgénikus burgonyában [102].

Számos ET jelátviteli elem vesz részt a sejtek ROF válaszának kialakításában. Az Arabidopsis erf6 ROF-indukált expressziója $\mathrm{Ca}^{2+}$ és NADPH-oxidáz (RbohD)-függő szignalizációt igényel. Az AtERF6 pozitív antioxidáns szabályozó a növényi növekedés és a stresszválasz során [103]. Az ET indukált MAPK kaszkád szabályozza a ROF termelődést az RBOH gének transzkripcionális szabályozásával [104]. A paradicsom TERF1 az SlEIL3 és SIEIL4 által szabályozott ERF transzkripciós faktor, exogén ROF generáló vegyületek hatására is indukálódik. A TERF1 ektopikus expresszáltatása dohányban fokozta a KAT expresszióját [105]. Továbbá Agrostis stolonifera előkezelése ACC-vel például fokozta SOD, az APX és a POD aktivitását hőstressz során [106]. Az 1- metilciklopropán kezelés (1-MCP) - ami elfoglalja az ET receptorok ET kötőhelyét, így gátolja az ET hatást - csökkentette a POD és a KAT aktivitását szilvában [107]. Az exogén Ethephon indukálta az NtKAT2 és NtKAT3 izoenzimek expresszióját dohánylevelekben [108]. A ROF amplifikálhatják az ET jelátvitelt az ETO1 és ET bioszintézis-asszociált géneken keresztül [104]. Burgonyagumók sebzésekor az ACC-ből nem-enzimatikus módon is képződhet ET, a $\mathrm{O}_{2}{ }^{\bullet-}$ és az ACC reakciója során [109].

A NO az ET bioszintézist is szabályozhatja, ráadásul többféle módon. Lúdfüben a NOA1-függő (NITRIC OXIDE-ASSOCIATED 1) NO akkumuláció blokkolta az ACS1 szeneszcencia-indukált bekapcsolását [110]. A Yang-ciklus különböző enzimjei is célpontjai lehetnek az S-nitrozilációnak. Ezzel szemben, exogén NO-donorok lúdfü és dohány nemszeneszcens leveleiben stimulálták az ET-termelést. A két molekula kölcsönös befolyással bír egymás bioszintézisére, hiszen az ACC kezelés NO emissziót váltott ki borsólevelekben, ahogyan Arabidopsis gyökér szubapikális régiójában is [111]. Az ET sztómazárást indukált a NO produkció fokozásával [112], viszont gátolta az ABA indukált sztómazárást a zárósejtek NO mennyiségének csökkentésével Vicia faba levelekben [113]. Mindezen túl, NO jelenlétében destabilizálódtak, majd proteolitikusan lebontódtak a VII csoportba tartozó ERFek [114]. Továbbá, az ein2-1 lúdfú sejtekben fokozott $\mathrm{O}_{2}{ }^{*-}$ és $\mathrm{ONOO}^{-}$akkumulációt figyeltek meg [115]. 


\subsubsection{Az etilén prekurzora, az 1-aminociklopropán-1-karbonsav (ACC)}

Az ET közvetlen prekurzora, az ACC, egy diszubsztituált, ciklikus alfa-aminosav $101 \mathrm{Da}$ molekulasúllyal. Háromtagú ciklopropán gyürüje az alfa szénatomhoz fuzionált [116]. Az ACC-t oxigén és aszkorbát jelenlétében az ACO ET-né alakítja $\mathrm{CO}_{2}$ és $\mathrm{CN}^{-}$képződése mellett, melyet a $\beta$-cianoalanin szintáz $\beta$-cianoalaninná konvertál. Az ET bioszintézisben betöltött funkciójához az ACO $\mathrm{Fe}^{2+}$ kofaktort és aktivátorként bikarbonátot igényel [16]. Az ACO transzkriptumok szöveti megoszlása fontos markere az ET-termelés lokalizációjának [117]. Az ACC és néhány konjugált formája gyorsan transzportálható - akár percek alatt - a növények szöveteiben, a xilémen és a floémen keresztül is [118]. Napraforgó-csíranövények 1 órás, 10 $\mu \mathrm{M}$ ACC-s kezelése során a ${ }^{14} \mathrm{C}$-ACC gyökérhez adását követően, 0,5 órával később már mérhető volt ${ }^{14} \mathrm{C}$-gyel jelölt ET kibocsájtás a levelekben, ahol 6 óra után visszaállt a normális ET emisszió értéke, ahogyan a gyökérben is. A ${ }^{14} \mathrm{C}-\mathrm{MACC}$ koncentrációk 2 órán belül túlhaladták a levél ${ }^{14} \mathrm{C}$-gyel jelzett ACC tartalmát, míg a gyökérben ez 6 órába tellett. 24 óra elteltével, lényeges mennyiségü radioaktivitás exudációt fedeztek fel a gyökérből mind az ACC, mind a MACC frakcióban [119]. Az ACC hosszútávú transzportja számos stressztípus hatására is (tápanyag-stressz, szárazság- vagy sóstressz) bizonyítottan megtörténik a gyökérből a hajtásba [16]. Az ACC szubcellulárisan kompartmentizálódhat a tonoplasztban [120]. A növények endogén ACC tartalmát a magasabb fényintenzitások növelik [121], továbbá az ET felszabadulás kapcsolódhat a fotoszintetikus aktivitáshoz is [122].

Az ET felhalmozódhat a növények külső környezetében is, mind a légtérben, mind a talaj gázfázisában. Hajdanán, a gépjárművek kipufogó rendszere mérhető mennyiségü ET-t bocsájtott ki a környezetbe, mely szennyezett területeken (akár $0,70 \mu \mathrm{L} \mathrm{L}^{-1}$ koncentrációt elérve) befolyásolta a növényi növekedést [123]. Az ET relatíve alacsony koncentrációban $(0,1$ $\mu \mathrm{L} \mathrm{L}^{-1}$ ) elősegíti a levél [124], a koleoptil vagy a petiólum megnyúlását bizonyos fajokban, míg a nagyobb koncentrációk gátló hatásúnak bizonyulnak [2]. Az ET-okozta növényi növekedésgátlás a legtöbb esetben $1 \mu \mathrm{L} \mathrm{L}^{-1}\left(6,5 \times 10^{-9} \mathrm{M}, 25{ }^{\circ} \mathrm{C}\right)$ ET koncentrációtól következik be, mely egyéb, tipikus tüneteket, mint például a levél epinasztiáját vagy korai szeneszcenciát eredményez [125]. Szerencsére, mára a gépjárművek ET kibocsátása lecsökkent, így az ET gáz csak speciális körülmények között érhet el gátló koncentrációt a természetben, ilyen a biomassza égetés vagy spontán erdőtüzek és a helyi/antropogén tevékenységből származó ET kibocsájtások [126]. A szennyezetlen területek ET koncentrációja 0,03-0,50 $\mu \mathrm{L} \mathrm{L}^{-1}$ között változhat [123].

Az ET parciális nyomása a talaj gázfázisában jóval magasabb, 0,50-17,60 $\mu \mathrm{L} \mathrm{L}^{-1}$ koncentráció közé eshet [124]. A talajban, az ET képződhet a szerves anyagok lebomlása során 
és néhány talajlakó mikroorganizmus szintén képes szintetizálni különböző prekurzorokból [118]. Nemcsak az ET, hanem az ACC is képes felhalmozódni a gyökér környezetében. A talajvízben az ACC elérheti a 0,23-0,52 $\mu \mathrm{M} \mathrm{L}^{-1}$ koncentrációt elárasztott paradicsomgyökerek környezetében [127]. Egyéb kis molekulával egyetemben, a növény által szintetizált ACC egy része szekretálódik a gyökerekböl a talajba és nemcsak más növények, hanem a gazdanövénnyel laza asszociációban élö, rhizoszféra-baktériumok is felvehetik [118]. E baktériumok közül számos törzs indol-3-ecetsavat, auxin típusú növényi hormont is termel, mely stimulálja az ET bioszintézisét a növényben az ACS serkentése által. Az ACC-deamináz (ACCD) enzimmel rendelkező talajbaktériumok lebontják az ACC-t, így a talajoldat illetve a talajlevegő ET/ACC szintjének csökkentésével stimulálják a gyökér növekedését [128]. Továbbá, ezek a mikroorganizmusok elősegíthetik az esszenciális elemek felvételét és megelőzhetik a környezeti stresszorok káros hatását a növényi szisztemikus rezisztencia indukálásával [118, 129].

14 vizsgált $S$. lycopersicum fajta csíranövényei közül a legtöbb magas, de a többi is legalább közepes érzékenységet mutatott az ET-re az etiolált csíranövények hipokotiljának ETindukált megnyúlásos növekedésgátlása alapján, melyet $100 \mu \mathrm{M}$-os exogén ACC kezelés segítségével monitoroztak. Kifejlett növények esetében - a levél epinasztia mértéke alapján is hasonló eredményeket tapasztaltak, bár utóbbi esetben a jelenséget exogén ET-nel váltották ki. Más Solanaceae családba tartozó fajban az ET válaszreakciók sokkal nagyobb mértékben függtek a fejlődési állapottól [130].

Az ACC-t számos tanulmány során alkalmazták ET-t generáló molekulaként a hormon hatásainak megismerésére. Az exogén ACC-nek a gyökér megnyúlására kifejtett, elsősorban gátló hatását $1 \mu \mathrm{M}$-nál kisebb koncentrációban is kimutatták, de különböző fajokban, széles, 5$50 \mu \mathrm{M}$-os koncentrációban is vizsgálták [131-133]. Mindezek mellett az exogén ACC megnövelheti a gyökér frisstömegét is [134], viszont 24 órás, $100 \mu \mathrm{M}$-os ACC kezelés csökkentette a gyökér hidraulikus vezetöképességét paradicsomban [135]. Agrostis stolonifera lombozatának, a hőstresszt megelőző, $100 \mu \mathrm{M}$-os ACC-vel történő permetezése növelte a hőtoleranciát, valószínűleg az antioxidánsok serkentésével [106]. Lemna minor 0,01-1000 $\mu \mathrm{M}$ os ACC oldatokban, sötétben történő inkubációja során nem figyeltek meg telítést az ACC felvételében, viszont az ET-termelés $10 \mu \mathrm{M}$ exogén ACC jelenlétében telítődött. Tapasztaltak mérhető növekményt az ET kibocsátásban 0,01 $\mu \mathrm{M}$ ACC jelenlétében is [136].

$\mathrm{Az}$ újabb eredmények azt sugallják, hogy az ACC ET-független módon is befolyásolhatja a növények életfolyamatait [16, 137] elsősorban a gyökérben [17, 138, 139], viszont a közelmúltban a hajtás esetében is mutattak ki ET független ACC hatást [140]. 


\subsection{A sóstressz, mint az egyik fö abiotikus stresszfaktor}

A helyhez kötött növényi életnek gyakorta kell megbirkóznia a kedvezőtlen környezeti feltételekkel, melyek közül a talaj magas sótartalma az egyik legfőbb abiotikus stressz tényező [141]. A sós talajok szilárd vagy folyékony fázisukban különféle sók ionjainak domináns befolyása alatt állnak [141]. Ugyanakkor, a növények ez által elszenvedett károsodásai faj-, fajta-, növekedési állapot-, környezeti faktor- és sóion-függők lehetnek, így nehéz pontosan definiálni e talajokat. Általánosan elfogadott kritérium, hogy ha a gyökérzóna telítési extraktumának - az a vízzel telített oldat, amit kivontak az adott talajmintából - elektromos vezetőképessége eléri, vagy meghaladja a $4 \mathrm{dS} \mathrm{m}{ }^{-1}$ értéket, $25^{\circ} \mathrm{C}$-on, illetve amennyiben a kicserélhető $\mathrm{Na}^{+}$mértéke eléri a 15\%-ot, a vizsgált talaj magas sótartalmúnak tekintendő [142, 143]. A FAO 2008-as adatbázisa szerint, a világon 800 millió ha földterület érintett, mely 2015re 1 milliárd ha-ra nőtt [144,145], beleértve az öntözött termőföldek legalább 20\%-át [146].

A talaj sóösszetétele szerint megkülönböztetjük a szalinitást, mely az összes ásványi só optimum feletti koncentrációját jelenti, illetve a szodicitást, mely a $\mathrm{Na}^{+}$többletet fejezi ki [147] A nátriumsók elektrolitjainak - leginkább nátrium klorid $(\mathrm{NaCl})$ és nátrium szulfát $\left(\mathrm{Na}_{2} \mathrm{SO}_{4}\right)-$ közel semleges reakciójával létrejövő nagy sótartalmú talajok a leggyakoribbak, melyek leginkább szárazabb régiókban fordulnak elő [141]. Európa összterületének 3,6\%-a- 73 millió ha - érintett a magas szodicitás által [145]. Hazánkban szikes talajok főleg a Duna-Tisza közén (Homokhátság), a Tiszántúlon (Körösvidék, Hortobágy, Nagykunság) találhatóak [148]. Az oldható sók felhalmozódása jelentősen csökkenti a talajok értékét és termőképességét, biológiai aktivitását, megváltoztatja a fizikai és kémiai tulajdonságaikat [141]. A problémát okozó legáltalánosabb kationok a $\mathrm{Na}^{+}$, a $\mathrm{Ca}^{2+}$ és a $\mathrm{Mg}^{2+}$, míg az anionok a $\mathrm{Cl}^{-}$, a $\mathrm{SO}_{4}{ }^{2-}$ és a $\mathrm{HCO}_{3}$. Mivel a $\mathrm{Na}^{+}$a talaj fizikai struktúráját is rontja és a $\mathrm{Na}^{+}$és a $\mathrm{Cl}^{-}$is toxikus a megfelelö koncentrációban a növényekre, ezért ezeket tekintik a legfontosabb ionoknak. A sós talajok kialakulhatnak természetes és mesterséges úton is. A nem megfelelő öntözési rendszerek használata kiemelkedő az antropogén hatások közül. A másodlagos sóhatás is felléphet, ha a talajban vagy a talajvíz mélyebb rétegeiben tárolt só mobilizálódik és eléri a gyökérzónát [149].

A rohamosan növekvő területü, magas sótartalmú talajok okozta probléma komoly, hiszen a termesztett haszonnövényeink többsége glikofita, tehát érzékenyek vagy hiperérzékenyek a talaj sótöbbletére [150]. Szerencsére akadnak köztük mérsékelt sótoleranciával rendelkező fajok/fajták - például a paradicsom - is, melyek növekedését a túl magas sókoncentráció szintén gátolja [151]. A talaj sótartalma a természetben általában fokozatosan nő meg, azonban antropogén hatásokra hirtelen is megemelkedhet [152]. 
A magas sótartalom növényekre gyakorolt kedvezőtlen hatásait sóstressznek nevezzük. Jelen disszertáció keretei között, sóstresszként a $\mathrm{NaCl}$ - mint a leggyakrabban előforduló és legtöbb problémát okozó sótípus - hatásait tárgyaljuk. Mindezek alapján elmondható, hogy a növények sóstresszre adott válaszreakcióinak alaposabb megismerése globális jelentőségü.

\subsubsection{A sóstressz-specifikus növényélettani hatások}

A sóstressz hatása a növényekre ozmotikus és ionikus komponensekre bontható [146]. Az ozmotikus komponens - mely megelőzi az ionikust - a talajoldat ozmotikus potenciáljának esését jelenti, ami csökkenti a víz hozzáférhetőségét a növények számára [153]. Ez megváltoztatja a gyökér hidraulikus konduktivitását és zavarokat okoz a xilémtranszportban is [147]. Az így kialakuló vízdeficit ABA-függő (például a sztómazárás) és ABA-független (például a fotoszintézis hatékonysága és a fotoinhibíció stb.) utak aktiválódásán keresztül [152] a biomassza produkció csökkenését eredményezi [154]. Az ozmotikus hatás a sókoncentráció emelkedésével azonnal jelentkezik, viszont - amennyiben nem történt plazmolízis - a gyökér növekedése hamar helyreáll, vagy beáll egy csökkent alapszintre, mely a hajtásban időben később tapasztalható [155]. A természetben az ozmotikus hatás kevésbé kifejezett [152].

Az intercelluláris térben található sóoldatok kémiai potenciálja kibillenti az apoplaszt és szimplaszt közti vízpotenciál egyensúlyát, mely turgornyomás csökkenést és végül növekedésgátlást eredményez. Ebben a helyzetben a sejtek ozmotikus adaptációra való képessége határozza meg a túlélésüket [150]. A NaCl kezelés gyorsan indukálja az inozitol1,4,5-tiszfoszfát (IP3) prekurzor, foszfoinozitid foszfatidilinozitol-4,5-biszfofoszfát bioszintézisét, és az IP3 koncentráció növekedése közvetíti a jelet a sejt $\mathrm{Ca}^{2+}$ mobilizálása felé. A citoszolikus $\mathrm{Ca}^{2+}$ a plazmamembrán, a tonoplaszt és az ER membránjaiban található $\mathrm{Ca}^{2+}$ pumpákon és csatornákon keresztül transzlokálódik. A downstream elhelyezkedő MAPK kaszkádok befolyásolják a génexpressziót számos transzkripciós aktivátor foszforilálásával. Az ozmotikus egyensúly felborulása során fontos a sejtmembrán integritásának megőrzése, mely membrán-újrarendeződés útján valósulhat meg Amennyiben a membránintegritás sérül, az elektrolitok kiszivároghatnak a sejtből. Az ozmotikus adaptáció megtörténhet kompatibilis ozmolitok akkumulálásával, melyek lehetnek különféle szerves ozmolitok - például egyszerü cukrok, diszacharidok, cukoralkoholok stb. - de jelentheti a szervetlen ionok, föleg a $\mathrm{K}^{+}$ felvételét és felhalmozását is. A kompatibilis ozmolitok helyreállíthatják a sejt ozmotikus potenciálját a metabolikus folyamatok gátlása nélkül. Továbbá ozmoprotektánsként védik a fehérjéket, a membránokat, illetve antioxindánsokként is funkcionálnak [152].

A sóstressz ionikus komponense a $\mathrm{Na}^{+}$és $\mathrm{Cl}^{-}$ionok lassú felhalmozódása által az ionhomeosztázisban okozott zavart jelenti. Az ionfelvétel megvalósulhat szimplasztikus és 
apoplasztikus úton. Például rizsben a $\mathrm{Na}^{+}$és a $\mathrm{Cl}^{-}$felvétele a xilémbe $50 \%$-ban apoplasztikus transzporttal megy végbe, mely egy folyamatos áramlást jelent a külső tér és a xilém között. A $\mathrm{Na}^{+}$beáramlás a sejtbe a legnagyobb mértékben a nemszelektív kationcsatornákon (NSCC) keresztül történik a glikofitákban, továbbá a folyamatban részt vehetnek a HKT1; az aquaporin AtPIP2,1; a shaker-típusú $\mathrm{K}^{+}$csatornák, mint az AKT1 (akár 30-40\%-ban) és az LCT1 kisaffinitású kation transzporter. Mindazonáltal, intakt gyökerekben az egyirányú $\mathrm{Na}^{+}$influx sebessége a 20-200 $\mu_{\mathrm{M} \mathrm{g}^{-1}}$ friss tömeg $\mathrm{h}^{-1}$ határok között mozog. $\mathrm{A} \mathrm{Na}^{+}$ionnal ellentétben a $\mathrm{Cl}^{-}$ esszenciális ion, mely $\mathrm{H}^{+} / \mathrm{Cl}^{-}$szimporttal juthat a sejtbe, feltételezhetőleg anion csatornákon keresztül, azonban a specifikus felvételének molekuláris mechanizmusa eddig ismeretlen [156]. A $\mathrm{K}^{+}$a növényekben a sejt legfontosabb, esszenciális kationja, alapvető szerepe van a turgornyomás fenntartásában, valamint a membránpotenciál, a membránintegritás és funkció megőrzésében, továbbá számos enzim müködéséhez szükséges [152]. A növényi sejtek ionfelvevő rendszerében a $\mathrm{Na}^{+} \mathrm{a} \mathrm{K}^{+}$direkt kompetitora, ráadásul magas sókoncentrációk esetén a $\mathrm{Na}^{+}$felvétele sokkal hatékonyabb, mint a $\mathrm{K}^{+}$-é [150]. A magas extracelluláris $\mathrm{Na}^{+}$ koncentráció az alacsony szelektivitású $\mathrm{K}^{+}$felvevő rendszereket érinti, míg a nagy-affinitású rendszerek tovább müködnek sóstressz során is és kiemelt szerepük van a sótoleranciában [152]. A citoplazmában felhalmozódott $\mathrm{Na}^{+}$a $\mathrm{K}^{+}$-hoz viszonyított, magasabb töltéssürüsége miatt több vizet vonz maga köré és dehidratálja a fehérjéket, melyek így elveszíthetik natív konformációjukat, továbbá a DNS-re is hasonló hatással lehet [156]. Stresszmentes körülmények között a citoszolban körülbelül $20 \mathrm{mM} \mathrm{Na}^{+}$és $100 \mathrm{mM} \mathrm{K}$ található, azonban amennyiben a $\mathrm{K}^{+} / \mathrm{Na}^{+}$arány ettől jelentősen eltér, az enzimatikus folyamatok, illetve a fehérjeszintézis gátlódhat [158]. Mivel a $\mathrm{Na}^{+}$és a $\mathrm{K}^{+}$ionok közti fizikokémiai hasonlóság nagy, kompetitív kapcsolat áll fent köztük a $\mathrm{K}^{+}$kötő enzimek katalitikus helyeiért [150], ez azonban nem minden enzimnél jelent gátlást, illetve azoknál, ahol mégis, a $\mathrm{Na}^{+}$mennyiségnek a $\mathrm{K}^{+}$ tartalom többszörösét kell elérnie [156]. A citoszol magas $\mathrm{K}^{+} / \mathrm{Na}^{+}$arányának megőrzése tehát fokozza a növények sótoleranciáját. A növényi védekezés megvalósulhat - többek között - a $\mathrm{Na}^{+}$vakuólumba történő kompartmentizációjával, valamint a kevésbé fontos szövetekben történő felhalmozásával [150]. $\mathrm{A} \mathrm{Na}^{+}$és a $\mathrm{K}^{+}$újraelosztása a sejtkompartmentumok között fontos a citoszol magas $\mathrm{K}^{+}$tartalmának fenntartásához [159]. A NaCl-indukált $\mathrm{K}^{+}$kieresztés a GORK-on (GUARD CELL OUTWARD RECTIFYING $\mathrm{K}^{+}$CHANNEL) keresztül valósul meg, melynek az aktivitás csökkenése segíti a sótoleranciát [160]. A sótürő halofiták képesek fenntartani a megfelelő $\mathrm{K}^{+} / \mathrm{Na}^{+}$arányt a citoplazmájukban, melyre speciális $\mathrm{K}^{+}$felvevő rendszereket fejlesztettek ki. A citoszolikus $\mathrm{Cl}^{-}$enzim inhibitor hatását $80-100 \mathrm{mM}$ koncentráció fölött fejti ki. továbbá, az ionikus komponens a membránpotenciál befolyásolásán 
keresztül - mivel számos transzportfolyamat feszültség-függő - megzavarhatja az esszenciális tápanyagok felvételét [156].

A külső tér megemelkedett $\mathrm{Na}^{+}$koncentrációjának érzékelését végző szenzort egyelöre még nem találták meg, azonban az egyik jelölt a SOS5 (SALT OVERLY SENSITIVE5) plazmamembrán lokalizált fehérje, továbbá az Annexin1 (ANN1) is képes érzékelni az extracelluláris $\mathrm{Na}^{+}$koncentráció emelkedését, melynek hatására $\mathrm{ROF}$-aktivált $\mathrm{Ca}^{2+}$ beáramlást indít el a sejtbe (6. ábra). A sejten kívüli $\mathrm{Na}^{+}$az intracelluláris $\mathrm{Ca}^{2+}$, foszfatidsav (PA) és ciklikus-guanidin monofoszfát (cGMP) növekedéséhez vezet. A sóstressz által indukált $\mathrm{Ca}^{2+}$ szignált a SOS3 - mirisztirált, EF-hand tartalmú, kalcium-kötő fehérje - érzékeli, mely elősegíti a Ser/Thr protein kináz, SOS2 és a SOS3 komplex képződését. Ez foszforilálja, és aktiválja a $\mathrm{SOS} 1, \mathrm{Na}^{+} / \mathrm{H}^{+}$antiportert, mellyel serkenti a $\mathrm{Na}^{+}$eltávolítását a citoplazmából, továbbá a SOS2SOS3 komplex meggátolja a $\mathrm{Na}^{+}$felvételét a HKT2-n keresztül. A SOS1 segíti a $\mathrm{Na}^{+}$ionok betöltését is a xilémbe. A PA ettől függetlenül az MPK6-on keresztül is aktiválhatja a SOS1-t. A SOS2 közvetlenül befolyásolhatja a vakuoláris ATP-áz (V-ATPáz) aktivitását is, illetve egyéb vakuolum transzporterét is, mint a CAX (ARABIDOPSIS CALCIUM EXCHANGER) és az NHX $\left(\mathrm{Na}^{+} / \mathrm{H}^{+}\right.$ANTIPORTER). A citoszolikus $\mathrm{Ca}^{2+}\left(\left[\mathrm{Ca}^{2+}\right]_{\text {cit }}\right)$ akkumuláció hathat a SOS1 gén promóterére is az RSA1-RITF1 (ROOT IN SALT MEDIUM 1-RSA1 INTERACTING TRANSCRIPTION FACTOR) komplex kialakulásának elősegítésével. A CDPK3 és a $\left[\mathrm{Ca}^{2+}\right]_{\mathrm{cit}}$ aktiválja vakuoláris kétpórusú $\mathrm{K}^{+}$csatornákat, így a $\mathrm{K}^{+}$kieresztését a vakuolumból a citoszolba. A cGMP megemelkedése valószínűleg a ciklikus nukleotid-kapuzott ioncsatornákon (CNGS) és a glutamát-receptorokon (GLR) keresztül gátolja a $\mathrm{Na}^{+}$felvételt. A PIP2;1, a CNGC és a GLR blokkolható $\mathrm{Ca}^{2+}$ hozzáadásával [156].

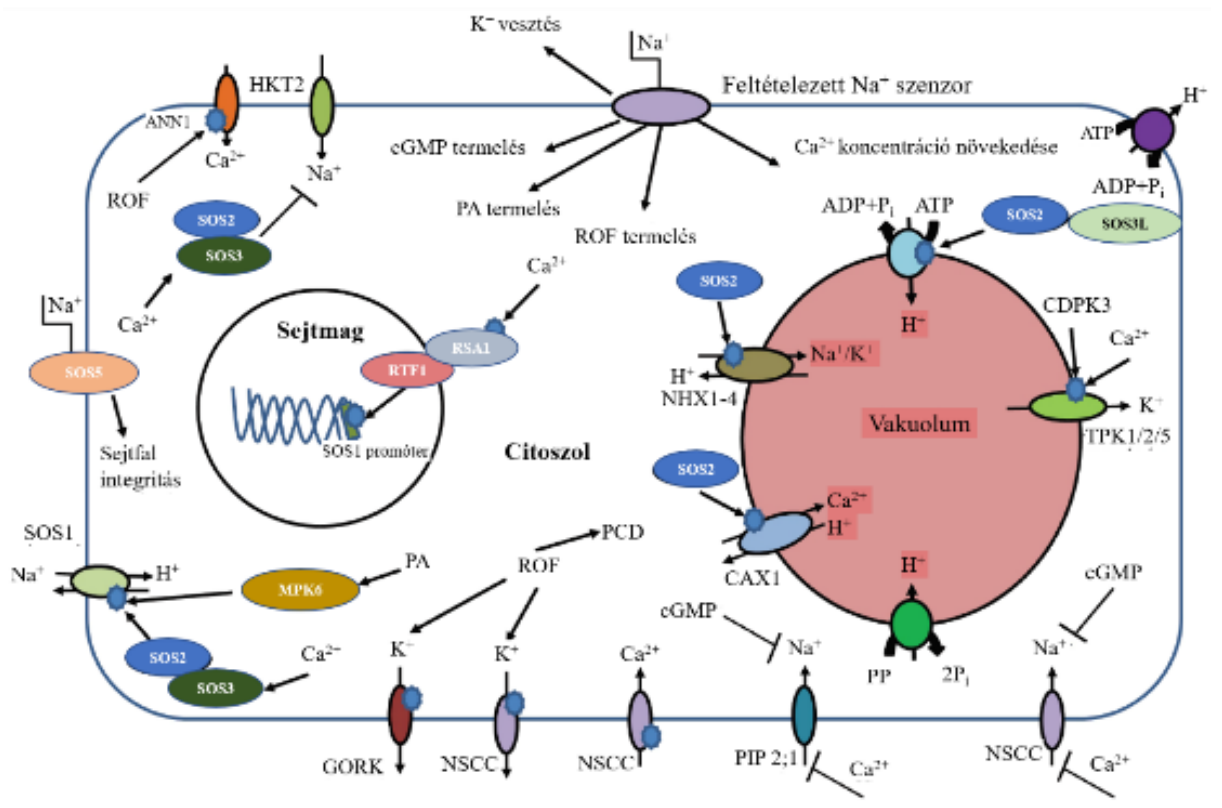

6. ábra A sóstresszt okozó ionok felvétele és az érzékelésük komponensei [156]. 
A SOS2-SOS3 komplex számos gén expresszióját is indukálja, beleértve a SOS1 gént is. $\mathrm{A} \mathrm{NaCl}$ végül interferál a $\mathrm{Ca}^{2+}$ felvétellel is, így csökkenti a kationnak a citoszolikus koncentrációját, mely egyébként fontos a membránstabilitáshoz, az ozmotikus egyensúly megtartásához és a sejten belüli jelátvitelhez [152]. A xilém parenchima sejtekben található AtHKT1 kiválasztja a $\mathrm{Na}^{+}$-ot a xilémelemekből a xilém parenchima sejtekbe. Ezt követően a $\mathrm{Na}^{+}$plazmodezmoszokon át a floémbe jut szimplasztikus diffúzióval. Ez csökkenti a levelek $\mathrm{Na}^{+}$terhelését sóstressz során [161]. A sóhatás kifejlődése során az akut, leginkább gyors ozmotikus fázis egy általános stresszválaszt vált ki a növényekből, viszont a késői válaszgének $\mathrm{NaCl}$ specifikusak [105].

A só-indukálta sztómazárás nem csupán a növény vízmegőrzését biztosítja, hanem a káros ionok felvételét is limitálja [162]. Ugyanakkor, ez a mechanizmus a fotoszintetikus aktivitás és a biomassza termelés csökkenéséhez vezet [154], a megmaradt energia pedig felhasználódik a védelmi folyamatok müködtetésére [163]. A növekedés csökkenése a fel nem használt fotoszintetikus termékek felhalmozódásához is vezethet a szövetekben [164]. A sóstressz csökkentheti a levelek klorofill és karotinoid tartalmát is [165], továbbá a kloroplasztiszban megnövekedhet a $\mathrm{Na}^{+}$és a $\mathrm{Cl}^{-}$koncentrációja és csökken a $\mathrm{K}^{+}$tartalom. Bár a RuBisCO nem túl sóérzékeny, a $\mathrm{Na}^{+}$más $\mathrm{CBC}$ enzimek aktivitását csökkentheti, így a sóstressz közvetlenül is gátolhatja a fotoszintézist. A megemelkedett ROF produkció, a $\mathrm{Na}^{+}$és a $\mathrm{Cl}^{-}$bejutása a sztrómába sóstressz során megváltoztatja a sztróma ionösszetételét, ami gátolja a gránumok összefüződését, így csökkenti PSII aktivitását. Mindemellett, a $\mathrm{K}^{+}$homeosztázis megzavarása a protonmozgató erő $\Delta \mathrm{pH}$ komponensére is hathat [163]. A $\mathrm{NaCl}$ ionjai károsíthatják a fénybegyüjtő komplexeket is [166]. A CET-PSI aktivitása sóstressz során alapvető szerepet játszhat, mivel nemcsak extra ATP-t termel, hanem csökkenti ROF képződést is, valamint az általa létrehozott ATP javasolt a $\mathrm{Na}^{+}$túlzott akkumulációjának megelőzésére szója kloroplasztiszokban. $\mathrm{A} \mathrm{Cl}^{-}$nemcsak a PSII komplex egyik kofaktora, hanem számos egyéb kloroplasztikus folyamatban is fontos szereplö, ugyanakkor a sóstressz okozta túlzott $\mathrm{Cl}^{-}$ akkumuláció telítheti a $\mathrm{Cl}^{-}$kötődését a PSII-höz, mely megemelkedett ROF produkcióhoz és fotoinhibícióhoz vezethet glikofitákban [163].

A ROF - pl. $\mathrm{O}_{2}{ }^{\circ-}, \mathrm{H}_{2} \mathrm{O}_{2},{ }^{\circ} \mathrm{OH}$ - és a NO szignálmolekulaként is részt vesznek a sóstresszválaszok kialakításában, túlzott mennyiségük azonban másodlagos, nitro-oxidatív stresszt indukál a növényi sejtekben, mely a sóstressz harmadik komponensének is tekinthető [105, 150]. Nyárfa kallusz sejtekben a só-indukált $\mathrm{H}_{2} \mathrm{O}_{2}$ termelés sótoleranciát indukált, a $\mathrm{Na}^{+}$szintek alacsonyan, míg a $\mathrm{K}^{+}$tartalom magasan tartásán keresztül. Ezen túlmenően, a sókezelésnek kitett, talajban nevelt Arabidopsis növények gyökereiben az AtrbohF által megnövelt 
vaszkuláris $\mathrm{ROF}\left(\mathrm{O}_{2}{ }^{\circ}\right)$ produkció korlátozza a xilémnedv $\mathrm{Na}^{+}$tartalmát, így csökkenti a $\mathrm{Na}^{+}$ transzportját a gyökérből a hajtásba, ahol így magasabb $\mathrm{K}^{+} / \mathrm{Na}^{+}$arányt és sótoleranciát indukált [167]. A ROF a Na+ és $\mathrm{K}^{+}$homeosztázist a plazmamembrán $\mathrm{Ca}^{2+}$ áteresztő csatornájának aktivitásán keresztül is szabályozhatja, mely befolyásolja a downstream elhelyezkedő komponenseket, mint az MPK-ok, a SOS2 és hasonló fehérjék. Továbbá, a ROF kifejtheti ezirányú hatását a SOS1 mRNS stabilitásának fokozásával, illetve a plazmamembrán $\mathrm{H}^{+}$ATPáz aktivitásának kontrollálásával [105].

A sóstressz során a tolerancia kialakításában kiemelt szerep jut az antioxidáns enzimeknek. A KAT aktivitása növekedhet és gátlódhat is hatására, továbbá az APX és a SOD aktivitás is érintett lehet [168]. A túlzott ROF produkció $\mathrm{K}^{+}$kiáramláshoz vezethet, főleg a GORK és NSCC csatornákon keresztül, ami inicializálja a PCD-t [156].

A sóstressz szignalizációban a NO és a többi RNF is szerepet játszhat [169]. Sókezelés során megemelkedett a NO felhalmozódás számos növényi szervben $[170,171]$. A szakirodalomi eredmények alapján a só-indukálta NO akkumuláció függ a stressz mértékétől és időintervallumától, valamint a szövetek korától [171-173]. A magas NO koncentráció önmagában nem olyan káros [174]. Sóstressz során a túlzott $\mathrm{NO}$ és $\mathrm{O}_{2}{ }^{*-}$ akkumuláció viszont $\mathrm{ONOO}^{-}$képződéséhez és nitrooxidatív stressz kialakulásához vezet a növényekben [175]. $\mathrm{NaCl}$ jelenlétében a NO fokozta az antioxidáns enzimek aktivitását [172, 176, 177], továbbá szignálként is funkcionálhat a megemelkedett $\mathrm{Na}^{+} / \mathrm{K}^{+}$hatására, aktiválhatja a plazmamembrán $\mathrm{Na}^{+} / \mathrm{H}^{+}$antiportert, a plazmamembrán és vakuoláris $\mathrm{H}^{+}$ATPázt és a $\mathrm{H}^{+}$pirofoszfatázt $[172$, 178]. A NO akkumuláció a sókezelés nagyon korai szakaszában - percektől órák - elérheti a maximum szintjét [98]. A sóstressz megnöveli az SNO akkumulációt is [179].

Sóstressz során a $\mathrm{Na}^{+}$felhalmozódás okozta membrán depolarizáció $\mathrm{K}^{+}$kiáramlást vált ki a sejtből. A $\left[\mathrm{Ca}^{2+}\right]_{\text {cit }}$ emelkedése fokozza a ROF produkciót, mely a már leírt módon egy pozitív visszacsatolási kört eredményez. Ez további $\mathrm{K}^{+}$effluxot okoz, majd a citoszol $\mathrm{K}^{+}$ tartalma lecsökken, ami aktiválja a cisztein proteázokat, végül PCD-hez vezet [158]. Az oxidatív robbanás, a DNS feldarabolódása, illetve a sejtmagi kromatin-kondenzáció is megfigyelhető a sóstressz-indukált PCD során a növényekben [180]. A DNS fragmentáció, mely akár a $\mathrm{NaCl}$ expozíciót követő 1 óra elteltével is detektálható, az ionikus stressz eredménye [181, 182]. A sejtek megemelkedett elektrolit-kieresztése is tipikus PCD jellemző, továbbá gyakran használják a sótolerancia meghatározására is, mivel legfőképpen a $\mathrm{K}^{+}$effluxot jelzi, ugyanakkor a $\mathrm{K}^{+}$fogyás társulhat $\mathrm{Ca}^{2+}$ és $\mathrm{H}^{+}$kiáramlással is a sejtből. [183-185]. Ugyanakkor a só-indukált PCD megjelenése vagy mértéke függ a stressz erősségétől is [98]. Fontos megjegyezni, hogy a sóstresszre adott válaszreakciók kialakulásában is kiemelt szerepet 
játszanak a növényi hormonok [186], azonban a jelen dolgozat a szupraoptimális sókoncentráció és az ET kapcsolatának vizsgálatára tér ki, melynek szakirodalmi vonatkozásait a 2.2.3. alfejezet tárgyalja.

\subsubsection{A paradicsom sóstressz reakciói}

A növények sóstresszre adott válaszreakciói nagyban függenek annak erősségétől. Nyolchetes paradicsomnövények $100 \mathrm{mM} \mathrm{NaCl-dal} \mathrm{történő} \mathrm{kezelése} \mathrm{a} \mathrm{hetedik} \mathrm{napra}$ szignifikáns mértékben csökkentette a hajtáshosszt, a teljes növény friss tömegét, valamint az össz-karotinoid tartalmat, a klorofill $a$ és $b$ összemennyiségét, ugyanakkor nem befolyásolta a membránok oxidatív károsodását jelző, malondialdehid (MDA) tartalmat [187]. Paradicsom szuszpenzióban kb. 20\%-os életképesség redukciót detektáltak egy hetes, $100 \mathrm{mM} \mathrm{NaCl}$ koncentráció hatására, mely azonban hosszabb távon regenerálódott. Ezzel szemben $300 \mathrm{mM}$ $\mathrm{NaCl}$ teljesen lecsökkentette a sejtek életképességét és az elektrolit-kieresztés mértéke is csaknem elérte a 70\%-ot, továbbá még magasabb ROF produkciót eredményezett. Bár itt 100 $\mathrm{mM} \mathrm{NaCl}$ hatására is csökkent a $\mathrm{K}^{+} / \mathrm{Na}^{+}$arány, $300 \mathrm{mM}$-os só esetében ez sokkal erősebbnek bizonyult az intenzív $\mathrm{K}^{+}$kieresztés és a sokkal nagyobb arányú $\mathrm{Na}^{+}$akkumuláció miatt [188]. Ezen túlmenően, $250 \mathrm{mM} \mathrm{NaCl} \mathrm{PCD-t} \mathrm{váltott} \mathrm{ki} \mathrm{paradicsom} \mathrm{sejtszuszpenzióban} \mathrm{is,} \mathrm{és} 6$ óra leforgása alatt a sejtek 80\%-a elpusztult [189]. Adódhatnak azonban apróbb különbségek a paradicsomfajták között a sótolerancia tekintetében [168]. Ezekből az eredményekből jól látható, hogy míg $100 \mathrm{mM} \mathrm{NaCl}$ szupraoptimális, növekedésgátló, de még tolerálható mértékủ sókoncentráció a paradicsom számára, $250 \mathrm{mM}$ már sejthalált indukál. A sóstresszre adott válasz, a tolerancia mértéke már a stressz kezdeti fázisában eldől [152]. Ugyanakkor relatíve kevés tanulmány foglalkozik a sóstressz korai eseményeivel a teljes növény szintjén.

\subsubsection{A sóstressz és az etilén hormon kapcsolata}

Az ET fontos szereppel bír a növények szupraoptimális sókoncentrációra adott válaszainak kialakításában, bár a szakirodalomban ellentmondásos eredmények születtek azzal kapcsolatosan, hogy az ET pozitív vagy negatív korrelációban áll-e a sótoleranciával. Számos ellentmondás valószínűleg azért jöhetett létre, mert sok tanulmány egyszerre csupán egy, vagy kevés komponenst vizsgál [146], legtöbbször szük időfelbontásban. A „stressz ET” termelődése általában két csúcsban történik. Az első, kisebb csúcs a stressz kialakulásának korai időszakában jelenik meg, és föleg a védelmi folyamatok beindulásáért felel, viszont kimeríti az aktuálisan rendelkezésre álló ACC készletet. Ez az állapot később újabb ACC készlet szintetizálásához vezet, mely a második ET csúcshoz szükséges, ami azonban sokkal nagyobb és hosszabb ideig is tarthat, akár több órás vagy hetes intervallumot jelenthet. A hosszasan megemelkedett ET produkció így PCD-t vagy szeneszcenciát indukálhat a szervben vagy a 
növényben [190]. A következökben részletezett ismeretek bepillantást nyújthatnak az ET komplex szerepére a sóstressz-válaszok kialakításában.

Sóstressz során az ET szabályozza például a $\mathrm{K}^{+} / \mathrm{Na}^{+}$homeosztázist a $\mathrm{Na}^{+}$Rboh-függö akkumulációján keresztül, illetve a $\mathrm{K}^{+}$tartalom Rboh-független befolyásolásával [146]. Az ET transzkripciós szinten is képes szabályozni a $\mathrm{K}^{+}$felvételt, például a HAK5 fehérjén keresztül, $\mathrm{K}^{+}$hiány és teljes tápanyagellátás mellett is [191, 192]. Sóstressz során, az ET-receptor mutáns Arabidopsis (etrl-3) sokkal érzékenyebbnek bizonyult a többlet $\mathrm{Na}^{+}$hatásaival szemben, mint a vad típusú társa, mely a mutáns növény fokozott elektrolit-kieresztésében, csökkent $\mathrm{K}^{+} / \mathrm{Na}^{+}$ arányában és redukált $\mathrm{PM} \mathrm{H}^{+}$-ATPáz aktivitásában nyilvánult meg. Mindemellett, a VT kallusz

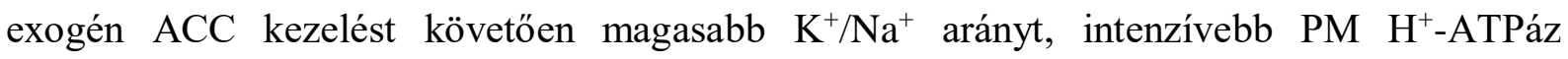
működést, és ennélfogva stimulált sótoleranciát mutatott, amely nem volt megfigyelhető az ETreceptor mutáns kultúrákban [97]. A sóstressz indukálta számos ACS izoforma expresszióját Arabidopsisban és gyapotban, valamint az ACS1-ét dohányban, illetve az ACO is indukálódik magas sókoncentráció hatására. Ugyanakkor számos esetben megfigyelték, hogy a megemelkedett ET produkció sóérzékenységhez, míg az ET tartalom csökkenése sótoleranciához vezetett [146]. Például búza ACO1 túlexpresszáló Arabidopsis növények megemelkedett ET-termeléssel és csökkent sótoleranciával rendelkeztek, továbbá rizs exogén ET kezelés is növelte a sóérzékenységet [105]. Az ET inszenzitív, etrl-1 funkciónyeréses lúdfü mutáns gyengébb sótoleranciával rendelkezik, míg a funkcióvesztéses etrl-7 mutáció az ellenkezőjét váltotta ki. Az ET befolyásolja számos só-válaszgén expresszióját is [193].

Az eddig leírtakkal ellenkezőleg, az in vivo ET-termelés segítette a sótoleranciát sós talajon nevelt lúdfü növényekben, ahol a transzspiráció aktív. Ennek az ellentéte figyelhető meg in vitro nevelt növényeknél, ahol a transzspiráció gátolt. A sótoleráns Antirrhinum majus genotípus hajtásában rövid és hosszútávon is magas ET produkciót mértek, míg a sóérzékeny mutánsban ez hamarabb lecsengett. Az ETO1 erős represszálása (sok ET) a nagy-affinitású $\mathrm{K}^{+}$ transzporter, a HAT5 expressziójának erős indukcióját okozta, mely fokozza a sejtek $\mathrm{K}^{+}$ akkumulációját a toleráns A. majus mutánsban. Ennek megfelelően az ETO1 felszabályozása (kevés ET) fokozta a sóérzékenységet az érzékeny genotípusban [194]. Arabidopsis ein2-5 és ein3-1 ET inszenzitív mutánsokban sóstressz hatására fokozódott a sejthalál mértéke, míg ez nem volt megfigyelhető ctrl-1 mutánsokban. Exogén ACC is csökkentette a PCD szintjét sóstressz során lúdfü protoplasztokban, valószínűleg a ROF kioltás serkentésén keresztül. Mindazonáltal számos egyéb - a dolgozatban fel nem sorolt - ET jelátviteli mutánsokat felsorakoztató vizsgálat alapján az ET szignalizáció inkább pozitív módon befolyásolja a sótoleranciát [105]. Több ERF gén túlexpresszáltatása dohányban és paradicsomban - pl. 
SIERF.F5 - szintén fokozta a növények sótürését [44]. Paradicsomban az SIERF.C1, -B2, -E3, - E2, - E4, - B7, -C11, -D3, -H6 is részt vesz a sóstressz-válaszok kialakításában [195].

Az ET indukálta, Rboh függő ROF termelés is kritikusnak mondható a folyamatban, egyebek mellett, részt vesz a sztómamozgás szabályozásában sóstressz során [105]. Lúdfüben az EIN3/EIL1 indukál 92-, míg represszál 121 gént sós körülmények között. Az ET hat a POD [105], a KAT és a SOD enzimek aktivitására sóstressz során. Érdekes megfigyelés, hogy a ctrl1 mutánsok alapból jóval kisebb biomasszával rendelkeztek, mint a másik két mutáns és a VT növény, ugyanakkor $\mathrm{K}^{+}$tartalmukat, szacharóz tartamukat, klorofill $a / b$ arányukat és az $\mathrm{F}_{\mathrm{V}} / \mathrm{F}_{\mathrm{M}}$ paraméterüket is jobban megőrizték sóstressz során, mint az ein2-5 és ein3-1 mutánsok, vagy a VT növény [196]. Az APX és az ET kapcsolata sóstressz során kevéssé vizsgált.

A ROF mellett a NO is szerepet játszik a növényi sóstressz-válaszok kialakításában, kapcsolata az ET-nel sóstressz során viszont eddig relatíve kisebb figyelmet kapott. Vad típusú lúdfü magvak sókezelése során az exogén ACC serkentette a csírázást. A rendszerhez cPTIO (2-(4-karboxifenil)-4,4,5,5-tetrametilimidazolin-1-oxil-3-oxid) - NO kioltó molekula csökkentette az ACC jótékony hatását [197]. A VT lúdfü kalluszkultúrák ACC vagy SNP kezelése növelte a sejtek $\mathrm{K}^{+} / \mathrm{Na}^{+}$arányát és a plazmamembrán $\mathrm{H}^{+}$-ATPáz aktivitását, ami növelte a sótoleranciát, azonban ez a jelenség az etrl-3 mutánsban nem volt megfigyelhető. Az SNP hatása a VT sejtekben szintén elmaradt ET bioszintézis inhibitor alkalmazása esetében. Érdekes módon, a VT sejtekben a $\mathrm{NaCl}$ hatására a kezelés 12. és 24. órájában detektáltak $\mathrm{NO}$ növekedést, 48 órát követően pedig a só gátolta a NO felhalmozódást, melyet az exogén ACC sem tudott visszafordítani [97]. A só indukálta, magas ET szinteket a levelek exogén NO donor kezelése csökkentette, mérsékelve a stressz káros hatásait [198]. Ugyanakkor, SNP alkalmazása sóstressz során serkentette a fiatal lúdfü csíranövényekben az ACS2 és EIN3 fehérjék génjeinek transzkripcióját. Míg az EIN3 túlakkumuláló növény kiváló sótoleranciával bírt a VT növényekhez képest is, addig az ein3eill kettős mutáns és a NO bioszintézis mutánsok a VT csíranövényekhez mérten is sokkal érzékenyebbnek bizonyultak a $\mathrm{NaCl}$ jelenlétére [199]. Paradicsom sejtszuszpenzióban az exogén ACC hozzáadása 250 mM NaCl kezelés jelenlétében [188], illetve $100 \mathrm{mM-os} \mathrm{sókoncentráció} \mathrm{különbözőképpen} \mathrm{befolyásolta} \mathrm{a} \mathrm{NO} \mathrm{produkciót}$ [189]. Az ET és a ONOO képződés kapcsolatát sóstressz során eddig még nem vizsgálták.

Az exogén ACC alkalmazása (10 és $100 \mu \mathrm{M}$ ) visszafordította a sóstressz által kiváltott fenotipikus változásokat lúdfüben [200] továbbá VT Arabidopsis csíranövények exogén Ethephon segítette a hajtás $\mathrm{K}^{+} / \mathrm{Na}^{+}$arányának a jobb megőrzését [196]. Más esetben az ACC serkentette a sóstressz indukálta oxidatív stresszt és a szeneszcenciát [201]. Két paradicsomfajta sókezelése során megfigyelték, hogy a toleráns fajtában az endogén ACC koncentráció 50\%- 
kal csökkent, míg az érzékenyben 50\%-kal nőtt [168]. A só indukálta korai, gyökérből kiinduló hormonális szignálok - mint az ACC hajtásba szállítása - fontos szereppel bírnak [202].

Az ET a szupraoptimális $\mathrm{NaCl}$ koncentrációra adott válaszok kialakításában betöltött fontos szerepe ellenére, kapcsolatát fotoszintézissel sóstressz során kevés esetben vizsgálták, szintén ellentmondásos eredményekkel [203, 204]. a hormon kapcsolatáról a PSI-el sóstressz során pedig nem található szakirodalmi adat. Bár a felsorolt példák rávilágítanak az ET és a sóstressz kapcsolatának bizonyos részleteire, azonban nagyon kevés tanulmány vizsgálja ezt a kölcsönhatást a sókezelés korai óráiban, kifejlett növényekben, valamint a különbözö, sóstressz-válasz komponensek változásait az idő függvényében összehasonlító tanulmányok száma pedig még kevesebb.

\section{Célkitüzések}

Az ET a növényekre gyakorolt hatásának koncentráció-, illetve időfüggő felbontású ismerete kiemelten fontos. A stressz hatására megemelkedett ET emisszió a stressz-ET koncentrációjától függően kedvezőtlenül hathat az akklimatizációra, azonban az ET szabályozhatja a stressz elleni védekezési mechanizmusokat is. Míg a stressz-ET fiziológiai szerepét széles körben vizsgálták, addig az ET prekurzorának, az ACC-nek növényekre gyakorolt közvetlen hatását alig, holott az ACC természetesen előfordul a növény gyökérzónájában, mennyisége a talajoldatban változhat. Különböző koncentrációinak a stressz akklimatizációban fontos paraméterekre (mint például az elemtartalom, ROF és RNF felhalmozódás, valamint a fotoszintézis változásai) gyakorolt hosszútávú, időfüggő hatásairól keveset tudunk. Szintén hiányosak az ismereteink a növények ET-státuszának és a fotoszintézisnek a kapcsolatáról a só-akklimatizáció korai szakaszában, különös tekintettel a PSI szabályozására. Ezen túlmenően, a növények ET státuszának kapcsolata a ROF és RNF akkumulációval és annak szabályozásával szintén alig ismert rövidtávú sókezelés során. Továbbá fontos megjegyezni, hogy a levélben bekövetkező változások nehezen értékelhetök a gyökérben történtek ismerete nélkül.

A dolgozatban a következő kérdésekre kerestük a választ:

1. Hogyan befolyásolja a gyökérzóna megemelt ACC tartalma a VT paradicsomnövények vízháztartási paramétereit, ionakkumulációját, valamint a ROF és RNF képződést a koncentráció függvényében?

2. Hogyan befolyásolja a gyökérzóna megemelt ACC tartalma a vad típusú paradicsomlevelek fotoszintetikus aktivitását a koncentráció és az idő függvényében? 
3. Milyen kapcsolatban vannak a gyökérzóna megemelt ACC tartalmával kapcsolatos fiziológiai változások a paradicsomnövények potenciális abiotikus stressztürő képességével? Mivel a nem patogén mikroorganizmusok által kiváltott, indukált szisztemikus rezisztencia (ISR) is az ET jelátvitel aktiválásán keresztül hat, felmerülhet a kérdés, hogy az ET/ACC-indukált változások gyakorolhatnak-e hatást az abiotikus stresszakklimatizációra?

4. Milyen, a sóstressz kialakulásához köthető, etilénfüggő válaszokat tapasztalhatunk a $\mathrm{NaCl}$ többlet által elöidézett sóstressz első támadási pontján, a gyökérben?

5. Miként módosítja az etilén jelátvitel ET receptor szintjén történő blokkolása és az exogén ACC kezeléssel megemelt szöveti ACC/etilén koncentráció a paradicsomnövények különböző sókoncentrációkra adott fiziológiai válaszait, valamint a ROF és RNF akkumulációját? A gyökérben bekövetkező változások miként vetülnek le a levélben?

6. Milyen ET státusz-függő változások történnek a szubletális és letális sóstressz hatására az antioxidáns enzimek aktivitásában és ezek egyes izoenzimeinek expressziójában, és milyen különbségek figyelhetők meg a gyökérben és a levelekben lezajló folyamatok között?

7. Milyen kapcsolatban áll a paradicsomnövények ET státuszával a fotokémiai rendszerek aktivitása, szabályozása, illetve a $\mathrm{CO}_{2}$ asszimilációval történő együttmüködése a sóstressz korai szakaszában?

\section{Anyagok és módszerek}

\subsection{Felhasznált növényi anyag, nevelési körülmények és kísérleti elrendezések}

Kísérleteinket Solanum lycopersicum Mill. L. cvar. Rio Fuego VT, valamint cvar. Ailsa Craig VT és homozigóta $N r / N r$, ET receptor mutáns növényeken végeztük, kétféle megközelítésben, de technikai okokból háromféle kísérleti elrendezésben (7. ábra). A paradicsommagokat három napon keresztül, sötétben, $26^{\circ} \mathrm{C}$-on csíráztattuk, majd (1. és 3. elrendezés) kéthetes korukig perlitben, végül 6-7 hetes korukig (a 7 valódi leveles állapot eléréséig) folyadékkultúrában, üvegházi körülmények között neveltük. A 2. kísérleti elrendezés során a vegetatívan szaporított paradicsomnövényeket talajkultúrában, 2,5 $\mathrm{kg}$ kereskedelmi talajban (Bioland Tőzegfeldolgozó Kft., Biatorbágy, Magyarország), $25 \mathrm{~cm}$ átmérőjű cserepekben neveltük, A talaj $\mathrm{N}\left(200-500 \mathrm{mg} \mathrm{L}^{-1}\right), \mathrm{P}_{2} \mathrm{O}_{5}\left(200-500 \mathrm{mg} \mathrm{L}^{-1}\right) ; \mathrm{K}_{2} \mathrm{O}\left(300-600 \mathrm{mg} \mathrm{L}^{-1}\right)$, fehér tőzeg $(50 \mathrm{~m} / \mathrm{v}$ $\%)$, fekete tőzeg $(50 \mathrm{~m} / \mathrm{v} \%)$, és $\mathrm{CaCO}_{3}\left(2 \mathrm{~kg} \mathrm{~m}^{-3}\right)$ összetevőket tartalmazott és 5,5-ös $\mathrm{pH}$ értékkel rendelkezett. A kísérletekhez a háromleveles állapotú hajtásokat elvágtuk és 4 hétig gyökereztettük folyadékkultúrában. 
A hidropóniában nevelt növények esetén az alábbi összetételü tápoldatot alkalmaztuk: $2 \mathrm{mM} \mathrm{Ca}\left(\mathrm{NO}_{3}\right)_{2}, 1 \mathrm{mM} \mathrm{MgSO} 4,0,5 \mathrm{mM} \mathrm{KH}_{2} \mathrm{PO}_{4}, 0,5 \mathrm{mM} \mathrm{Na}_{2} \mathrm{HPO}_{4}, 0,5 \mathrm{mM} \mathrm{KCl}$ és a mikroelemek $\left(10^{-6} \mathrm{M} \mathrm{MnSO}_{4}, 5 \times 10^{-7} \mathrm{M} \mathrm{ZnSO}_{4}, 10^{-7} \mathrm{M} \mathrm{CuSO}_{4}, 10^{-7} \mathrm{M}\left(\mathrm{NH}_{4}\right)_{6} \mathrm{Mo}_{7} \mathrm{O}_{24}, 10^{-5} \mathrm{M}\right.$ $\mathrm{H}_{3} \mathrm{BO}_{4}$ ), 2x10 ${ }^{-5} \mathrm{M}$ Fe-EDTA, pH 5,8 [205], melyet kétnaponta cseréltünk. A növényeket 12/12 órás nappali/éjszakai fotoperiódusban, $300 \mu \mathrm{mol} \mathrm{m} \mathrm{m}^{-2} \mathrm{~s}^{-1}$ PPFD-n (F36W/GRO fénycsövek, Osram Sylvania, Danvers, MA, USA), 55-56\%-os relatív páratartalmon (RH) és $25 / 22^{\circ} \mathrm{C}$ nappali/éjszakai hömérsékleten neveltük. Vizsgálatainkat reggel 8 és délután 16 óra között végeztük, melyhez - ahogy a különbözö kísérleti elrendezések esetében pontosan jelezzük - a gyökér teljes hosszát (fögyökér + oldalgyökerek + járulékos gyökerek), járulékos gyökerek teljes hosszát vagy $1 \mathrm{~cm}$-es apikális régiójukat, illetve a hajtáscsúcstól számított a 3-4. levélemeleten elhelyezkedő kifejlett, nem-szeneszcens leveleket használtuk fel. Az alkalmazott kísérletei elrendezések további részletei a következők:

1. elrendezés: A vizsgálataink első szakaszában, a gyökérzóna megemelt ACC tartalmának hatását vizsgáltuk egyéb, specifikus stresszfaktor alkalmazása nélkül, $S$. lycopersicum Mill. L. cvar. Rio Fuego paradicsomfajta leveleiben és gyökereiben. Az előző alfejezetben leírt állapotú növények gyökérzónáját a vízkultúrában alkalmazott, a természetben is előforduló $0,01 \mu \mathrm{M}$-os és 1,0 $\mu \mathrm{M}$-os, valamint a stressz ET mennyiségéhez hasonló ETszintet generáló, $100 \mu \mathrm{M}$-os ACC (Sigma-Aldrich, St. Louis, MO) kezelésnek tettük ki egy hetes intervallumban. Frissen feloldott ACC-t adtunk a tápoldathoz a cserék alkalmával is. A fotoszintetikus aktivitást naponta, a levelek és teljes gyökerek ET produkcióját az 1. 2. és 7. napon, a növekedési paramétereket, a gyökércsúcsok-, valamint a levelek ROF és RNF tartalmát, a teljes gyökerek és levelek szénhidrát és elemtartalmát a 7. napon vizsgáltuk. A kísérletek mintavételi időpontjai 8-13 óra közé estek. Egy minta előállításához egy egyedi növény részeit használtuk fel, a mintaszámokat pedig az ábraaláírásokban, „n” jelöléssel adtuk meg. Ez alól kivételt képeztek a fluoreszcens mikroszkópiás mérések, ahol 4-4 növényből 1616 szövet-szegmenst preparáltunk. Az összes kísérletet háromszor ismételtük.

\section{2. elrendezés: Munkánk soron következő lépéseként kétféle erōsségü sókezelés} rövidtávú hatásait vizsgáltuk VT és $\mathrm{Nr}$ mutáns gyökerekben, S. lycopersicum Mill. L. cv. Ailsa Craig genetikai háttérben. A hajtás gyökereztetése során kifejlődött, egyforma típusú, járulékos gyökereket hidropónikus kultúrában, a tápoldaton keresztül $100 \mathrm{mM}$-os növekedésgátló, de tolerálható koncentrációjú, a továbbiakban „szubletális”, vagy 250 mM-os, néhány napon belül a növény pusztulását okozó, a továbbiakban „letális” koncentrációjú NaCldal kezeltük. A mintavételeket a kezelés megkezdését követő 1, 6, illetve 24 óra elteltével 
végeztük el. Egy minta előállításához egy egyedi növény részeit használtuk fel, a mintaszámokat pedig az ábraaláírásokban, „n” jelöléssel adtuk meg. A kezeléseket délelőtt 9 órakor indítottuk el, továbbá legalább háromszor ismételtük meg független kísérletsorozatok formájában. A fehérje- és az elemtartalmak, illetve a proteolitikus aktivitás meghatározásához a járulékos gyökerek teljes hosszát; az elektrolit-kieresztés (EL) és a DNS fragmentáció vizsgálatához pedig a gyökércsúcsokat használtuk fel. A felsorolt kísérletekhez tartozó minták a kezelések 24 órás mintavételi időpontjából származtak. Ezen túlmenően, az ET produkció, a sejt életképesség, valamint a ROF és RNF akkumuláció monitorozását a gyökércsúcsokban végeztük az összes időpontban.

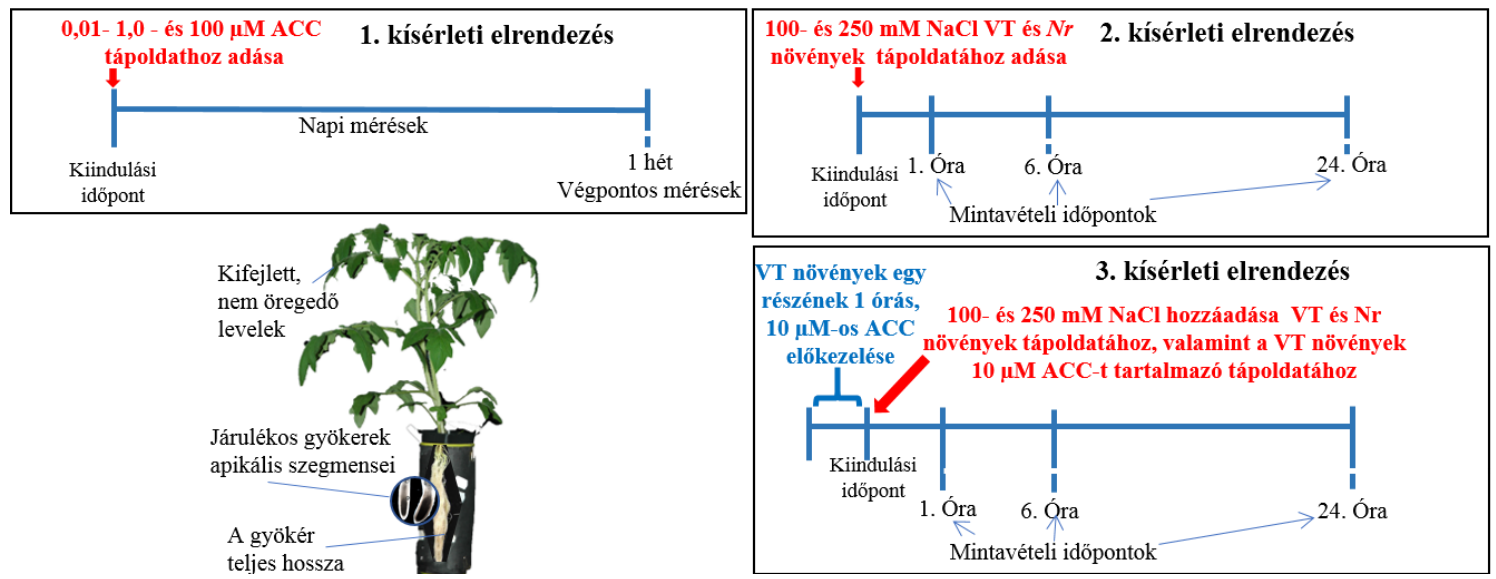

7. ábra Az alkalmazott kísérleti elrendezések

\section{3. elrendezés: Kísérleteink harmadik szakaszában, a kétféle erősségü, rövidtávú} sókezelésre adott válaszreakció és a növények ET státuszának kapcsolatát VT, VT és exogén ACC kezelt, valamint $\mathrm{Nr}$ mutáns $\mathrm{S}$. lycopersicum Mill. L. cv. Ailsa Craig paradicsomfajta gyökereiben és leveleiben vizsgáltuk. Ennek megfelelően, a VT növények egy része a tápoldaton keresztül, 1 órás, $10 \mu \mathrm{M}$-os koncentrációjú - nem túl magas, de biztosan ET többletet generáló - ACC előkezelésben részesült, melyet a $100 \mathrm{mM}$-os, valamint $250 \mathrm{mM}$-os $\mathrm{NaCl}$ tápoldathoz adása követett, az ACC jelenlétének megtartása mellett. Ebben az időpontban, melyet a kísérlet kezdő, tehát 0 . időpontjának tekintettünk, a VT növények fennmaradó része, továbbá a $N r$ mutánsok is részesültek az említett sókezelésekben. A mintavételeket a kezelés megkezdését követő 1, 6, illetve 24 óra elteltével végeztük el. Egy minta előállításához egy egyedi növény részeit használtuk fel, a mintaszámokat pedig az ábraaláírásokban, „n” jelöléssel adtuk meg. A sókezeléseket délelőtt 9 órakor indítottuk el, továbbá legalább háromszor ismételtük meg független kísérletsorozatok formájában. Az ET produkciónak, a friss és száraz tömegnek, az oldható cukor- és keményítőtartalomnak, a vizsgált antioxidáns enzimek aktivitásának és génexpressziójának a meghatározásához a gyökér teljes hosszát és a leveleket, a ROF és RNF akkumuláció monitorozásához a járulékos gyökerek 
apikális szegmensét és a leveleket, a relatív víztartalom, a vízpotenciál és a fotoszintetikus aktivitás változásainak nyomon követéséhez pedig csak a leveleket használtuk fel az összes időpontban. A teljes gyökér és a levelek elemtartalmát, valamint a levelek pigmenttartalmát a 24 órás időpontban határoztuk meg.

\subsection{Növekedési paraméterek meghatározása}

A már definiált növényi részeket friss tömegeik meghatározását követően $60^{\circ} \mathrm{C}$-on, tömegállandóságig szárítottuk, majd meghatároztuk száraz tömegeiket.

\subsection{A növényi részek etilén kibocsájtásának meghatározása}

1000 mg (1. kísérleti elrendezés), 500 mg (2. és 3. kísérleti elrendezés), duplán desztillált (dd.) vízzel mosott növényi anyagot inkubáltunk 1 órán keresztül, sötétben, légmentesen záró, szilikongumi tetővel ellátott flaskákban. A szövetek hidratáltságát dd. víz hozzáadásával tartottuk fent. A küvetta gázteréből $2,5 \mathrm{~mL}$ térfogatot injektáltunk egy légmentesen záró fecskendő segítségével a lángionizációs detektorral és aktivált alumínium oszloppal rendelkező Hewlett-Packard 5890 Series II gáz kromatográfba (Hewlett-Packard, Wilmington, USA, DE). A He vivőgáz áramlási sebességét $35 \mathrm{~mL} \mathrm{~m}^{-1}$, míg a $\mathrm{H}_{2}$-ét $30 \mathrm{~mL} \mathrm{~m}^{-1}$ és a levegőét $300 \mathrm{~mL} \mathrm{~m}^{-}$ 1 értékeken tartottuk. Az alábbi hőmérsékleti paramétereket használtuk: $100^{\circ} \mathrm{C}$ a kolonna, $120^{\circ} \mathrm{C}$ az injektor és $160^{\circ} \mathrm{C}$ detektor esetében [98]. A növényi anyag feletti légtér térfogatának meghatározásához a mérés elvégzése után az üvegcsék egyenkénti, dd. vízzel történő feltöltését alkalmaztuk. A növényi szövetek által kibocsájtott ET mennyiségét ET standardok sorozatának segítségével határoztuk meg.

\subsection{Vízháztartással kapcsolatos vizsgálatok}

A relatív víztartalom (RVT) monitorozásához megmértük a levelek friss tömegét (aktuális vízállapotú tömeg), majd 12 órás, ioncserélt vízben történő áztatást követően meghatároztuk a minták teljes vízállapotú tömegét, minekután $60{ }^{\circ} \mathrm{C}$-on tömegállandóságig szárítottuk, majd meghatároztuk száraz tömegeiket. A RVT kiszámítása az alábbi képlet szerint történt:

$$
\frac{\text { Aktuális vízállapotú tömeg }- \text { Száraz tömeg }}{\text { Teljes vízállapotú tömeg }- \text { Száraz tömeg }} \times 100
$$

A vízpotenciál $\left(\psi_{\mathrm{w}}\right)$ meghatározásához a 3.-4. levélemeleten elhelyezkedő összetett levél nyelét a szártól 2 cm-re elvágtuk, majd a levelet a vágott felszínnel a külső környezet felé a nitrogén gázzal feltöltött nyomáskamrába (PMS instrument Co., Corvallis, Oregon, USA) helyeztük. A kamrában a $\mathrm{N}_{2}$ gáz beáramoltatással kialakuló nyomás növelése során a levélnyél vágott felületén folyadékcsepp jelenik meg. Az ennek detektálásakor leolvasott nyomásértéket (Bar) 0,1-gyel szorozva kapjuk a levél aktuális vízpotenciálját (MPa-ban). 


\subsection{Az elemtartalmak meghatározása}

Az elemtartalmak meghatározásához 100 mg növényi mintát - a gyökereket a szárítást megelőzően, két alkalommal, $50 \mathrm{~mL}$ dd. vízzel mostuk - emésztettünk tömény $\mathrm{HNO}_{3}$ és $30 \%$ os $\mathrm{H}_{2} \mathrm{O}_{2}$ elegyében, $200{ }^{\circ} \mathrm{C}$-on egy mikrohullámú roncsolóban (MarsXpress, CEM, USA). A $\mathrm{HNO}_{3}$ (Reanal, Budapest, Magyarország) és $\mathrm{H}_{2} \mathrm{O}_{2}$ (Reanal) mennyisége 5- és $4 \mathrm{~mL}$ volt az 1 . kísérleti elrendezés, valamint 6- és $2 \mathrm{~mL}$ a 2 . és 3. kísérleti elrendezés esetében. A lehült mintákat HPLC minőségü vízzel hígítottuk, majd Packard üvegcsövekbe (Packard, Groningen, Hollandia) transzferáltuk és $4^{\circ} \mathrm{C}$-on tároltuk az analízisig. Az 1. és 2. kísérleti elrendezés esetében az elemtartalmakat atomabszorpciós spektroszkópia (Hitachi Z-8200, Tokió, Japán) [98], míg a 3. elrendezés esetében induktív-csatolású plazma tömegspektrometria (ICP-MS) segítségével határoztuk meg, az utóbbit a Nemzeti Agrárkutatási és Innovációs KözpontÖntözési és Vízgazdálkodási Kutatóintézet intézet (NAIK-ÖVK) Környezetanalitikai Központ Vizsgáló Laboratóriumának közremüködésével.

\subsection{Fluoreszcens mikroszkópiás mérések}

A gyökércsúcsok $\mathrm{O}_{2}{ }^{\bullet-}$ akkumulációját $10 \mu \mathrm{M}$ dihidroetidium (DHE) segítségével, míg a $\mathrm{H}_{2} \mathrm{O}_{2}$ tartalmát $50 \mu \mathrm{M}$ 10-acetil-3,7-dihidroxifenoxazin (AR; ADHP vagy Amplifu ${ }^{\mathrm{TM}}$ Red) alkalmazásával határoztuk meg [206]. A gyökércsúcsi szegmensek, illetve a levelekből, dugófúró segítségével preparált, $1 \mathrm{~cm}$ átmérőjü korongok NO akkumulációját $10 \mu \mathrm{M}$ 4-amino5-metilamino-2', $7^{\prime}$-difluorofluoreszcein diacetát (DAF-FM-DA), a ONOO- tartalmát pedig 10 $\mu \mathrm{M}$ aminofenil fluoreszcein (APF) segítségével monitoroztuk [207]. A fluoreszcens festékeket a Sigma-Aldrich forgalmazótól vásároltuk, valamint a kísérletet megelőzően hígítottuk $25 \mathrm{mM}$ os (1. kísérleti elrendezés) illetve $10 \mathrm{mM}$-os (2. és 3. kísérleti elrendezés) TRIS(hidroximetil) aminometán (TRIS)/sósav (HCl), pH 7,4 pufferrel. A gyökércsúcsokat szobahőmérsékleten, sötétben inkubáltuk 30 percig az AR és DHE, míg 30 percig (2. kísérleti elrendezés), valamint 40 percig (1. és 3. kísérleti elrendezés) a DAF-FM-DA és APF festékoldatokban. A levélkorongokat $2 \times 5$ percig vákuum alatt infiltráltuk a festékekkel, majd további 30 perces inkubációban részesítettük (vákuum nélkül). Az inkubációs idők leteltével, a mintákat két alkalommal mostuk TRIS-HCl pufferben, 10 percig (2. kísérleti elrendezés), illetve 5 percig (1 és 3. kísérleti elrendezés).

A gyökércsúcsi sejtek életképességét fluoreszcein-diacetát (FDA) (Sigma-Aldrich) festék segítségével határoztuk meg, melyet $10 \mathrm{mM}$ 2-(N-morfolino) etánszulfonsav (MES)/kálium-klorid ( $\mathrm{KCl})(\mathrm{pH}$ 6,15) pufferrel higítottunk a kísérletet megelőzően. A 
gyökércsúcsokat sötétben, 10 percig inkubáltuk $10 \mu \mathrm{M}$-os FDA festék jelenlétében, majd 2x10 percig mostuk MES/KCl (pH 6,15) oldatban [207].

A fluoreszcencia intenzitását 5X objektívvel felszerelt, Zeis Axiowert fluoreszcens mikroszkóp segítségével határoztuk meg (200M típus, Carl Zeiss Inc., Jena, Németország). A digitális fényképeket egy nagyfelbontású digitális kamerával (Axiocam HR, HQ CCD camera; Carl Zeiss Inc.,) készítettük el, melyhez a 10- (gerjesztés: 450-495 nm, emisszió: 515-565 nm) vagy a $20 \mathrm{HE}$ filter szetteket (gerjesztés: $535-585 \mathrm{~nm}$, emisszió: 600-655 nm) használtunk. A pixelintenzitás mérését az AXIOVISION REL. 4.8 (Carl Zeiss Inc.,) szoftverrel végeztük, mely a gyökér csúcsától számított 2 mm-es távolságban, $150 \mu \mathrm{m}$-es átmérőjü körökben történt. A levélkorongok nagyságát tekintve, a középvonaluknál négyfelé osztottuk őket, majd minden negyed cikkely esetében a vágott felszíntől $100 \mu \mathrm{m}$ távolságra elhelyezett, 3 db, ugyancsak 150 $\mu \mathrm{m}$ átmérőjü körben mértük meg a pixelintenzitást, melyek átlagát vettük 1 levélkorong pixelintenzitás értékének.

\subsection{A levélszövetek $\mathrm{H}_{2} \mathrm{O}_{2}$ és $\mathrm{O}_{2}{ }^{\bullet-}$ akkumulációjának monitorozása}

A levelek $\mathrm{H}_{2} \mathrm{O}_{2}$ tartalmát Takács és mtsai. [208] munkája lapján határoztuk meg. 100 mg mintát 0,5 mL jéghideg, 0,1\%-os triklórecetsavban (TCA) homogenizáltunk, majd centrifugáltunk 10000 g-vel 20 percig, $4{ }^{\circ} \mathrm{C}$-on. A reakcióelegy 0,25 mL, $10 \mathrm{mM}$-os kálium-foszfát pufferből (pH 7,0), továbbá $0,5 \mathrm{~mL}, 1 \mathrm{M}$-os kálium jodidból (KI) és $0,25 \mathrm{~mL}$ felülúszóból állt. A minták $\mathrm{H}_{2} \mathrm{O}_{2}$ tartalmát 10 perc inkubációt követően 390 nm-en mértük egy Uvikon XL (Secomam, Alés Cedex, Franciaország) spektrofotométerrel, különböző koncentrációjú $\mathrm{H}_{2} \mathrm{O}_{2}$ (SigmaAldrich) oldatsorozat segítségével.

A levelek $\mathrm{O}_{2}{ }^{\bullet-}$ akkumulációját Bournonville és Diaz-Ricci [209] módszere alapján követtük nyomon. Elsőként a hisztokémiai festés során, levélnyelükkel történő leválasztásukat követően, az ép leveleket azonnal vákuum infiltráltuk $10 \mathrm{mM}$ nátrium azidban (Sigma-Aldrich) 10 percig, majd ezt az oldatot eltávolítva, 0,1\% tetrazóliumkék-klorid (NBT) nátriumsó (Sigma-Aldrich) oldatban 2 percig. A leveleket ezt követően az NBT oldatban inkubáltuk 2 órán keresztül, teljes sötétségben, vákuum jelenléte nélkül. Mindkét anyagot 50 mM-os káliumfoszfát pufferben ( $\mathrm{pH} 7,7)$ oldottuk fel a kísérletet megelőzően. Az inkubációs idő leteltével, a mintákat $96 \%$-os etanolban, $96^{\circ} \mathrm{C}$-on forraltuk kétszer 30 percig. A formazánt kiszárított levelekből, háromszor, $2 \mathrm{M}$ kálium-hidroxid $(\mathrm{KOH})$ :kloroform $(1: 1, \mathrm{v} / \mathrm{v})$ jéghideg elegyével, mindhárom alkalommal 10 perces, 3000 g-vel, $18{ }^{\circ} \mathrm{C}$-on történő centrifugálás segítségével vontuk ki. A kloroformos extraktumot nitrogén-áram alatt szárítottuk jégen, majd a szilárd formazán maradékot dimetilszulfoxid:2M KOH (1,6:1, v/v) elegyében oldottuk fel. Az így 
kapott formazán oldatok optikai denzitását egy Uvikon XL (Secomam) spektrofotométerrel mértük $630 \mathrm{~nm}$-en. A kalibrációs görbéket in vitro termelt és tisztított formazán standard oldataival vettük fel, melyet tovább korrigáltunk a cellulóz mátrix által visszatartott formazán mennyiségével. $\mathrm{A}_{2}{ }^{*-}$ tartalmat az NBT-vel alkotott reakciójának hozamából becsültük meg: négy elektron/mol redukált diformazán képződik a folyamat során.

\subsection{A pigmenttartalmak meghatározása}

A pigmentanalízis Sims és Gamon [210] munkája alapján történt. 25 mg tömegü levélkorongokat 24 órán keresztül inkubáltuk $1 \mathrm{~mL} \mathrm{100 \% -os} \mathrm{aceton} \mathrm{jelenlétében,} \mathrm{sötétben,}$ $4^{\circ} \mathrm{C}$-on, majd a centrifugálást $\left(12000 \times \mathrm{g}, 15\right.$ perc, $\left.4^{\circ} \mathrm{C}\right)$ követően a felülúszót félre tettük. A visszamaradt szöveteket $1 \mathrm{~mL}$ aceton/TRIS pufferben (80:20, v/v, pH 7,8) inkubáltuk újabb 24 órán keresztül sötétben, $4^{\circ} \mathrm{C}$-on. Újabb centrifugálást követően a felülúszókat egyesítettük. A kivonatok pigmenttartalmát egy Uvikon XL (Secomam) spektrofotométer és az alábbi egyenletek segítségével határoztuk meg:

Klorofill $a(\mathrm{Kl} b)=0,01261 \times \mathrm{A}_{661}-0,001023 \times \mathrm{A}_{534}-0,00022 \times \mathrm{A}_{643}$

Klorofill $b(\mathrm{Kl} a)=0,02255 \times \mathrm{A}_{643}-0,00439 \times \mathrm{A}_{534}-0,004488 \times \mathrm{A}_{661}$

Karotinoidok $(\mathrm{Kar})=\left(\mathrm{A}_{470}-17,1 \times(\mathrm{Kl} a+\mathrm{K} 1 b)-9,479 \times\right.$ Antocianin korrekció $) / 119,26$

Antocianin korrekció $=0,0821$ x A534- 0,00687 x A643-0,002423 x A661

\subsection{A levelek fotoszintetikus aktivitásának vizsgálata}

A steady-state nettó $\mathrm{CO}_{2}$ asszimilációs rátát $\left(\mathrm{A}_{\mathrm{N}}\right)$, a sztómák vízgőzvezető képességét $\left(\mathrm{g}_{\mathrm{sw}}\right)$, valamint az intercelluláris és az atmoszférikus $\mathrm{CO}_{2}$ koncentráció arányát $\left(\mathrm{C}_{\mathrm{i}} / \mathrm{C}_{\mathrm{a}}\right)$ egy Li-6400as, infravörös gázanalizátorral felszerelt mérörendszerrel (Li-Cor, Lincoln, NE, USA) határoztuk meg. A levélkamra hőmérsékletét $25^{\circ} \mathrm{C}$-ra, az exogén forrásból származó, $450 \mu \mathrm{mol}$ $\mathrm{s}^{-1} \mathrm{CO}_{2}$ tartalmú levegő áramlási sebességét $300 \mu \mathrm{mol} \mathrm{s}{ }^{-1}$-ra. A fényforrás $221 \mu \mathrm{mol} \mathrm{m} \mathrm{m}^{-2} \mathrm{~s}^{-1}$ PPFD mellett, 90\%-ban vörös (635 nm) és 10\%-ban kék (465 nm) fényből állt [205].

A klorofill $a$ fluoreszcencia és a PSI (P700) abszorbancia változásainak monitorozása szimultán történt egy DUAL-PAM-100 (Heinz-Walz, Effeltrich, Germany) fluoriméter segítségével, DUAL-E és DUAL-DR méröfejeket használatával [211]. Röviden, 30 perc sötétadaptációt követően, a modulált méröfény $\left(620 \mathrm{~nm}, 5 \mu \mathrm{mol} \mathrm{m}^{-2} \mathrm{~s}^{-1}\right)$ bekapcsolásakor a sötétadaptált állapotban mérhető minimális fluoreszcencia $\left(\mathrm{F}_{0}\right)$ meghatározásra került. Ezt követően, a sötétadaptált állapotban mérhető maximális fluoreszcencia szint $\left(\mathrm{F}_{\mathrm{M}}\right)$ megállapítása egy $14000 \mu \mathrm{mol} \mathrm{m}{ }^{-2} \mathrm{~s}^{-1}$ intenzitású telítési impulzus segítségével történt, majd kezdetét vette a levelek folyamatos, aktinikus megvilágítása $216 \mu \mathrm{mol} \mathrm{m}^{-2} \mathrm{~s}^{-1}$ erösségü vörös (635 nm) fénnyel. 13 percet követően, rögzítettük a fény-adaptált állapot steady state fluoreszcencia szintjének $\left(\mathrm{F}_{\mathrm{S}}\right)$ értékét, illetve egy telítési fényimpulzus adásával, a fényadaptált állapot maximális 
fluoreszcencia szintjét $\left(\mathrm{F}_{\mathrm{M}}{ }^{\prime}\right)$ is. A fényadaptált állapot minimális fluoreszcencia szintjét $\left(\mathrm{F}_{0}{ }^{\prime}\right)$ az aktinikus fény tranziens kikapcsolásakor, 3 másodperces távoli vörös megvilágítás $(720 \mathrm{~nm}$, $5 \mu \mathrm{mol} \mathrm{m} \mathrm{m}^{-2} \mathrm{~s}^{-1}$ ) segítségével határoztuk meg. Ezt követően az 1. táblázatban foglalt paramétereket vizsgáltuk [212].

1. táblázat A klorofill $a$ fluoreszcencia és PSI aktivitással kapcsolatos paraméterek

\begin{tabular}{|c|c|c|}
\hline A PSII maximális kvantumhatásfoka sötétadaptált levelekben & $\mathrm{Fv} / \mathrm{F}_{\mathrm{M}}$ & $\mathrm{F}_{\mathrm{V}} / \mathrm{F}_{\mathrm{M}}=\left(\mathrm{F}_{\mathrm{M}}-\mathrm{F}_{0}\right) / \mathrm{F}_{\mathrm{M}}$ \\
\hline A PSII effektív kvantumhatásfoka fényadaptált levelekben & $\mathrm{Y}(\mathrm{II})$ & $\mathrm{Y}(\mathrm{II})=\left(F_{\mathrm{M}}^{\prime}-F_{s}\right) / F_{\mathrm{M}}^{\prime}$ \\
\hline A (fény)szabályozott energia disszipáció kvantumhatásfoka & Y(NPQ) & $\begin{array}{l}\mathrm{Y}(\mathrm{NPQ})=(1-Y(I I)-1) /\left(\left(F_{\mathrm{M}} / F_{\mathrm{M}}^{\prime}-\right.\right. \\
\left.1)+1+q L x\left(F_{\mathrm{M}} / F_{0}-1\right)\right)\end{array}$ \\
\hline A szabályozatlan energia disszipáció kvantumhatásfoka & $\mathrm{Y}(\mathrm{NO})$ & $\begin{array}{l}\mathrm{Y}(\mathrm{NO})=1 /\left(\left(F_{\mathrm{M}} / F_{\mathrm{M}}{ }^{\prime}-1\right)+1+q L x\right. \\
\left.\left(F_{\mathrm{M}} / F_{0}-1\right)\right)\end{array}$ \\
\hline $\begin{array}{l}\text { A PSII reakciócentrumok nyitott állapotú frakciója fényadaptált } \\
\text { állapotban }\end{array}$ & $\mathrm{qL}_{\mathrm{L}}$ & $\mathrm{qL}=\left(\mathrm{F}_{\mathrm{M}^{\prime}}-\mathrm{F}_{s}\right) /\left(\mathrm{F}_{\mathrm{M}}{ }^{\prime}-\mathrm{F}_{0}{ }^{\prime}\right) \times \mathrm{F}_{0}{ }^{\prime} / \mathrm{F}_{s}$ \\
\hline A PSI fotokémiai kvantumhatásfoka & $\mathrm{Y}(\mathrm{I})$ & $Y(I)=1-Y(N D)-Y(N A)$ \\
\hline $\begin{array}{l}\text { A PSI donor oldali limitációjából fakadó nem fotokémiai kioltás } \\
\text { kvantumhatásfoka }\end{array}$ & $\mathrm{Y}(\mathrm{ND})$ & $\mathrm{Y}(\mathrm{ND})=1-\mathrm{P} 700 \mathrm{red}$ \\
\hline $\begin{array}{l}\text { A PSI akceptor oldali limitációjából fakadó nem fotokémiai kioltás } \\
\text { kvantumhatásfoka }\end{array}$ & $\mathrm{Y}(\mathrm{NA})$ & $\mathrm{Y}(\mathrm{NA})=\left(\mathrm{P}_{M}-\mathrm{P}_{M}^{\prime}\right) / \mathrm{P}_{M}$ \\
\hline $\begin{array}{l}\text { A CEF-PSI kvantumhatásfokának Y(II) feletti aránya / CEF-PSI } \\
\text { mértéke [213] }\end{array}$ & $\mathrm{Y}(\mathrm{CEF}) / \mathrm{Y}(\mathrm{II})$ & $\mathrm{Y}(\mathrm{CEF}) / \mathrm{Y}(\mathrm{II})=[\mathrm{Y}(\mathrm{I})-\mathrm{Y}(\mathrm{II})] / \mathrm{Y}(\mathrm{II})$ \\
\hline
\end{tabular}

A P700 redox változásait a 830 és a 875 nm-es mérőfények differencia jeléből Klughammer és Schreiber [211] munkája nyomán határoztuk meg. Az $\mathrm{F}_{0}$, valamint az $\mathrm{F}_{\mathrm{M}}$ meghatározást követően a maximális $\mathrm{P} 700$ jel $\left(\mathrm{P}_{\mathrm{M}}\right)$ detektálása is megtörtént. A 13 perces aktinikus megvilágítás végén adott telítési impulzussal a $\mathrm{P}_{\mathrm{M}}{ }^{\prime}$ meghatározását is elvégeztük, majd az 1 . táblázatban foglalt paraméterek segítségével követtük nyomon a PSI aktivitását.

\subsection{Cukortartalmak meghatározása}

Az oldható cukortartalom meghatározásához az 1. kísérleti elrendezés esetében $0,5 \mathrm{~g}$ friss növényi anyagot folyékony $\mathrm{N}_{2}$-ben elporítottunk, majd $5 \mathrm{~mL}, 80 \%$-os etanollal (2 mM-os HEPES pufferrel [pH 7,5] készítve) elhomogenizáltunk. A centrifugálást követően (15000 x g, $4{ }^{\circ} \mathrm{C}, 30$ perc), az üledéken a leírtak szerint ismételtük meg az extrakciót, majd az egyesített felülúszóból $45{ }^{\circ} \mathrm{C}$-on, vákuum segítségével elpárologtattuk a folyadékot. A kiszárított mintákat $3 \mathrm{~mL}$ dd. vízzel oldottuk fel, 0,3 g polivinilpirollidon (PVP) hozzáadása mellett. Ezt követően az összes oldható cukor mennyiségét a fenol-kénsavas módszerrel határoztuk meg [214], mely során a reakcióelegyeket 490 nm-en fotometráltuk egy Kontron Uvicon 530 típusú spektrofotométerrel (Milano, Olaszország). Az összes oldható cukor tartalmakat szacharóz koncentrációsorral készített kalibrációval határoztuk meg.

Ezen túlmenően, vizsgáltuk a minták szacharóz, glükóz, fruktóz és szorbitol koncentrációját enzimatikus reakciók segítségével, melyhez Boehringer Mannheim/R Biopharm (Németország) cukor analízis kitet (Kat. Sz. 10716260 035) használtunk a 
szacharóz/D-glükóz/D-fruktóz esetében [205], továbbá, ugyanazon gyártótól származó Dszorbitol analízis kitet (Kat. Sz. E 0670 057) a szorbitol tartalom meghatározásához [215], a gyártó által leírt instrukciókat követve. Röviden, a glükóz koncentrációját a $\mathrm{D}$-glükóz hexokináz (HXK) általi, G-6-P dehidrogenáz jelenlétében végbemenő glükóz-6-foszfáttá (G-6P) alakításával, a vak mintával történő korrekciót követően, a keletkező NADPH 340 nm-en való detektálásával kaptuk meg. A D-fruktózt a HXK fruktóz-6-foszfáttá (Fru-6-P) alakította, melyből a foszfoglükóz-izomeráz G-6-P-tot képez. A szacharóz invertáz általi hidrolízisét követően meghatároztuk a minta D-glükóz mennyiségét a fentebb leírtak szerint. A keletkezett NADPH mennyisége sztöchiometrikus volt a D-glükóz, D-fruktóz és a szacharóz mennyiségével kapcsolatban. A D-szorbitolból a NAD+függő szorbitol dehidrogenáz által Dfruktóz képződött, majd a redukált NADPH-t a jódnitrotetrazolium redukciója diaforáz reakció során elfogyasztotta. A képződött formazán abszorbanciáját 492 nm-en detektáltuk - ahogy a fentebb jellemzett reakciók esetében is - egy Kontron Uvicon 530 típusú spektrofotométerrel.

A 3. kísérleti elrendezés esetében az összes oldható cukor, valamint keményítő tartalmakat Poór és mtsai. [216] által jellemzett módszer mikrotiter körülmények között elvégezhető adaptációjának segítségével határoztuk meg, Laurentin és Edwards [217] munkája nyomán. Röviden, az oldható cukrokat $100 \mathrm{mg}$ folyékony $\mathrm{N}_{2}$-ben elporított mintából, $1 \mathrm{~mL}$, 80\%-os etanol hozzáadását követő, $80{ }^{\circ} \mathrm{C}$-on, 30 percig történő inkubációval vontuk ki két alkalommal. A homogenizátumot 2600 x g-n centrifugáltuk 10 percig, mindkét esetben, majd az egyesített felülúszóból 20-20 $\mu$ L-t, 96-helyes, polisztirol mikroplatekbe (Nunc, Maxisorp R, Life Technologies, USA) osztottunk szét. 15 perces, $4^{\circ} \mathrm{C}$-on történő inkubációt követően, 100 $\mu \mathrm{L}$ Antron reagenst (0,2 \% Antron [Normapur, VWR Int., Leuven, Belgium] 72\%-os kénsavoldatban) adtunk a mintákhoz. A mikroplateket lefedtük, majd enyhe vortex keverést követően 3 percig, $92{ }^{\circ} \mathrm{C}$-os vízfürdőben, majd 5 percig szobahőmérsékleten, végül 15 percig, $45{ }^{\circ} \mathrm{C}$-kon inkubáltuk. A színváltozás abszorbanciáját $630 \mathrm{~nm}$-en detektáltuk, plate olvasó spektrofotométer segítségével, az extrakciós puffert tartalmazó reagenst használva referenciaként. Az oldható cukortartalom meghatározáshoz a kalibrációt glukóz-monohidrát oldatsorozatot használtunk. A keményítő tartalom meghatározásához, az oldható cukor méréshez használt mintákból visszamaradt üledéket mostuk $1 \mathrm{~mL}$ dd. vízzel, majd $1 \mathrm{~mL}, 1,1 \%$ os $\mathrm{HCl}$ jelenlétében emésztettük $100^{\circ} \mathrm{C}$-on, 30 percig, melyet 10 perces, 2600 x g-n történő centrifugálás követett. A felülúszó keményítő tartalmát a már leírtak szerint határoztuk meg, a hidrolizált keményítő (Normapur, VWR Int.) oldatsorozattal. 


\subsection{A proteolitikus aktivitás meghatározása}

$500 \mathrm{mg}$ gyökérmintát $0,5 \mathrm{~mL}$ extrakciós puffer $(50 \mathrm{mM}$ nátrium-acetát, $1 \mathrm{mM}$ ditiotreitol; $\mathrm{pH}$ 6,1) jelenlétében homogenizáltunk $4{ }^{\circ} \mathrm{C}$-on, majd 10 percig, 11300 x g-n centrifugáltunk, $4{ }^{\circ} \mathrm{C}$ on. A felülúszók fehérjetartalmát Bradford [218] módszere alapján, spektrofotometriásan határoztuk meg 595 nm-en, borjú szérum albumint használva standardként.

Azokazeint (Sigma-Aldrich) alkalmaztunk nemspecifikus szubsztrátként a teljes proteolitikus aktivitás meghatározásához. $50 \mu \mathrm{L}$ kivonatot $0,3 \mathrm{~mL}, 1 \%$-os azokazeinnel (w/v) és $650 \mu \mathrm{L}$ kálium-foszfát pufferrel inkubáltunk $37^{\circ} \mathrm{C}$-on 2 óráig, majd a reakciót $300 \mu \mathrm{L}, 10 \%$ os (w/v) TCA hozzáadásával és $4{ }^{\circ} \mathrm{C}$-on, 20 percig történő inkubációjával állítottuk le. A minták centrifugálását (10 perc, $4{ }^{\circ} \mathrm{C}, 11300$ g) követően a felülúszó abszorbanciáját $440 \mathrm{~nm}$-en mértük. A teljes proteolitikus aktivitás egy egysége (U) az enzim mennyiségének a reakció ideje alatti, 0,01 abszorbancia egység / perc hozama alapján lett meghatározva. A cisztein proteáz aktivitás meghatározásához, a kivonatokat $10 \mathrm{mM}$, specifikus, cisztein proteáz inhibitor, a transz-epoxiszukcinil-L-leucilamid (4-guanidin)bután (E-64, Sigma-Aldrich) jelenlétében inkubáltuk 1 órán át, $20{ }^{\circ} \mathrm{C}$-on azokazeines kimutatás előtt. A cisztein proteáz aktivitás kiszámítása a gátlószer hiányában mért proteolitikus aktivitás arányában történt [219].

\subsection{Antioxidáns enzimek aktivitásának monitorozása}

A folyékony $\mathrm{N}_{2}$-ben történő porítást követően, $100 \mathrm{mg}$ növényi anyagot feloldottunk $400 \mu \mathrm{L}$ extrakciós pufferben $\left(50 \mathrm{mM}\right.$-os $\mathrm{K}^{+} / \mathrm{Na}^{+}$foszfát puffer, $\mathrm{pH} 7,0 ; 1 \mathrm{mM}$ fenil-metil-szulfonilfluorid (PMSF); 1\% polivinilpolipirrolidon (PVPP)). Az APX specifikus aktivitás nyomon követéséhez $1 \mathrm{mM}$ redukált aszkorbátot is (ASC) adtunk az extrakciós pufferhez. A centrifugálás után $\left(10\right.$ perc, $\left.10844,6 \times \mathrm{g}, 4^{\circ} \mathrm{C}\right)$ a felülúszókkal dolgoztunk tovább. Az enzimaktivitások meghatározásához egy Uvikon XL Secomam spektrofotométert használtunk.

A SOD specifikus aktivitás meghatározásának alapja a tetrazóliumkék (NBT) riboflavin, metionin és fény jelenlétében történő redukciójának gátlása [220]. A reakció 5 mMos NBT, 0,2 mM-os riboflavin, $13 \mathrm{mM}$ metionint, $0,1 \mathrm{mM}$ etiléndiamin tetraecetsav nátriumsó (NaEDTA) elegyét, $50 \mathrm{mM}$-os $\mathrm{K}^{+} / \mathrm{Na}^{+}$foszfát puffert $(\mathrm{pH} 7,0)$ és 11,8 $\mu \mathrm{L}$ enzimkivonatot tartalmazott. $200 \mu \mathrm{mol} \mathrm{m} \mathrm{m}^{-2} \mathrm{~s}^{-1}$ PPFD fényforráson történő, 5 perces inkubációt követően a keletkezett formazán extinkcióját 560 nm-en mértük. Egy enzimegység (U) megegyezik az NBT redukciójának 50\%-os gátlását okozó enzimmennyiséggel.

A KAT specifikus aktivitás meghatározásához az enzimkivonathoz $50 \mathrm{mM}-\mathrm{os} \mathrm{K}^{+} / \mathrm{Na}^{+}$ foszfát puffert ( $\mathrm{pH}$ 7,0) és $10 \mathrm{mM}$-os $\mathrm{H}_{2} \mathrm{O}_{2}$-ot adtunk, majd $240 \mathrm{~nm}$-en monitoroztuk a $\mathrm{H}_{2} \mathrm{O}_{2}$ bomlását [220]. A 0,2 és az 1,2 perc között mért extinkcióváltozás alapján $1 \mathrm{U}$ az $1 \mu$ mol $\mathrm{H}_{2} \mathrm{O}_{2}$ 
elbontását 1 perc alatt elvégző enzimmennyiség, amelyet az $\varepsilon_{240}=39,4 \mathrm{mM}^{-1} \mathrm{~cm}^{-1}$ extinkciós koefficens alapján számítottunk.

A POD specifikus aktivitás meghatározásához az enzimkivonathoz $50 \mathrm{mM}-\mathrm{os} \mathrm{K}^{+} / \mathrm{Na}^{+}$ foszfát puffert ( $\mathrm{pH} 7,0)$ és 1\%-os gvajakolt, valamint 1\%-os $\mathrm{H}_{2} \mathrm{O}_{2}$-ot adtunk, majd 470 nm-en követtük nyomon a gvajakol oxidációja által okozott abszorbancia növekedést [221]. 1 U az 1

$\mu$ mol tetragvajakol képződését 1 perc alatt katalizáló enzimmennyiség, amelyet az $\varepsilon_{470}=26,6$ $\mathrm{mM}^{-1} \mathrm{~cm}^{-1}$ extinkciós koefficens alapján számítottunk.

Az APX specifikus aktivitás vizsgálatához az enzimkivonathoz $50 \mathrm{mM}-\mathrm{os} \quad \mathrm{K}^{+} / \mathrm{Na}^{+}$ foszfát puffert (pH 7,0), 5 mM redukált ASC-ot és 10 mM-os $\mathrm{H}_{2} \mathrm{O}_{2}$-ot adtunk, majd 290 nm-en követtük nyomon az ASC oxidációját. $1 \mathrm{U}$ az 1 momol ASC oxidációját 1 perc alatt katalizáló enzimmennyiség az $\mathcal{E}_{290}=2,8 \mathrm{mM}^{-1} \mathrm{~cm}^{-1}$ extinkciós koefficiens alapján [220].

\subsection{Egyes antioxidáns izoenzimek és a NADPH-oxidáz génexpressziójának vizsgálata}

Az össz-RNS kivonása során a folyékony $\mathrm{N}_{2}$-ben, kvarchomok segítségével elporított, körülbelül 100 mg növényi mintához $1 \mathrm{~mL}$ TRI reagenst (1,822 M guanidium izotiocianát, 11,36 mM nátrium-citrát, $200 \mathrm{mM}$ kálium-acetát $(\mathrm{pH} 4,0), 0,7341 \mathrm{mM}$ N-laurilszarkozin, $45,45 \%$ fenol) majd 3 perces, $65{ }^{\circ} \mathrm{C}$-os inkubáció után $200 \mu \mathrm{l}$ kloroformot adtunk. Centrifugálást (10000 x g, 15 perc, $4{ }^{\circ} \mathrm{C}$ ) követően $375 \mu$ hideg kloroform:izoamilalkohol elegyébe (24:1) helyeztük át a felülúszót. Ismételt centrifugálási lépést követően, a vizes fázisban található RNS-t $500 \mu 1$ izopropanolban csaptuk ki, 10 perces, szobahőmérsékleten történő inkubálás során. A centrifugálást követően az üledéket 70\%-os etanollal tisztítottuk [222]. A poliszacharid szennyezések eltávolításához az üledéket $100 \mu \mathrm{L}$ molekuláris biológiai tisztaságú vízben (AccuGene, Thermo Fisher Scientific, UK) oldottuk fel, majd hozzáadtunk $100 \mu \mathrm{L} 2 \mathrm{M}$-os kálium-acetátot és 30 percen keresztül jégen inkubáltuk. Centrifugálást követően (12000 x g, 20 perc, $\left.4{ }^{\circ} \mathrm{C}\right)$ a felülúszót $500 \mu \mathrm{L}, 96 \%$-os etanolba helyeztük, majd -20 ${ }^{\circ} \mathrm{C}$-on inkubáltuk 15 percig. Ismételt centrifugálási lépés után az üledéket 70\%-os etanollal mostuk, végül rövid, steril légáram alatti szárítást követően AccuGene vízben oldottuk fel. A kivont RNS integritását agaróz gélerektroforézissel ellenőriztük [222].

A genomi DNS maradványokat DNáz enzim (Fermentas Fermentas UAB, Vilnius, Litvánia) segítségével távolítottuk el, $17 \mu 1$ AccuGene vizet, $4 \mu 1$ DNáz puffert, 0,2 $\mu 1$ RNáz inhibitort (Fermentas Fermentas UAB) és 12-18 $\mu \mathrm{g}$ RNS mintát tartalmazó reakcióelegy 30 perces, $37^{\circ} \mathrm{C}$-on történő inkubációja során. A fehérjéket kloroform:fenol (1:1, v/v) elegyével elimináltuk, majd centrifugálást követően $\left(10000 \mathrm{x}\right.$ g, 15 perc, $\left.4{ }^{\circ} \mathrm{C}\right)$ a vizes felülúszót $200 \mu \mathrm{l}$ kloroformmal tisztítottuk. Az így kapott felülúszót $550 \mu 1$, jéghideg etanol és $3 \mathrm{M}$-os Na-acetát jelenlétében 18 órát inkubáltuk, majd a centrifugálást követően $\left(12000 \mathrm{x} \mathrm{g}, 15\right.$ perc, $\left.4{ }^{\circ} \mathrm{C}\right)$ kapott 
csapadékot 70\%-os etanollal mostuk, végül AccuGene vízben oldottuk fel. A tisztított teljesRNS integritását agaróz gélerektroforézissel ellenőriztük [222].

A $1 \mu$ g-nyi teljes-RNS mintából cDNS-t szintetizáltunk 200 U reverz transzkriptáz (RT) enzimet, (Fermentas Fermentas UAB) $4 \mu \mathrm{RT}$ puffert, $0,5 \mu 1$ random hexamer primert, $1 \mu 1,25$ mM-os dNTP keveréket, 0,5 $\mu$ l RNáz inhibitort és $13 \mu \mathrm{l}$ AccuGene vizet tartalmazó elegy segítségével, 1 órás, $37^{\circ} \mathrm{C}$-on zajló reakcióban [220].

A mitokondriális SIMnSOD, a kloroplasztikus SlFeSOD és $S l C u / Z n S O D$, a peroxiszomális SIKAT1, SIKAT2, SIKAT3, a citoszolikus SIAPX1 és SlAPX2, valamint a plazmamembrán lokalizált SIRBOH1 gének expresszióját qvantitatív, valós-idejü PCR (qRTPCR) segítségével monitoroztuk. Az NCBI (http://www.ncbi.nlm.nih.gov/) és a Sol Genomics (http://solgenomics.net/) adatbázisok segítségével azonosított szekvenciákra a Primer 3 szoftverrel [223] terveztünk primereket (1. melléklet), melyek génspecificitását az NCBI BLAST (http://blast.ncbi.nlm.nih.gov/Blast.cgi) használatával ellenőriztük. A qRTPCR reakcióelegy 1,6 $\mu 1$ 20-szorosára higított cDNS-böl, $0,4 \mu 1$ primerpárból, $3 \mu 1$ nukleázmentes vízből és $5 \mu \mathrm{l}$ SYBRGreen mixböl (Fermentas Fermentas UAB) állt. A 7 perces, $95{ }^{\circ} \mathrm{C}$-os kezdeti hevítésböl, majd 40 ciklusos sorozatból $\left(95^{\circ} \mathrm{C} 15\right.$ percig, $60^{\circ} \mathrm{C} 1$ percig) álló program során a SYBRGreen festék intenzitását egy qTOWER PCR készülékkel (Analytik Jena, Németország) követtük nyomon, majd a termékek specifikusságát az olvadási görbék analízisével ellenőriztük $\left(55^{\circ} \mathrm{C}\right.$-tól $90^{\circ} \mathrm{C}$-ig, $\left.0,2^{\circ} \mathrm{C} / \mathrm{ms}\right)$. Az adatokat a qPCRsoft szoftver (Analytik Jena) segítségével értékeltük ki. A génexpressziós változások meghatározására a 2${ }^{\Delta \Delta \mathrm{Ct}}$ módszert alkalmaztuk [224], referencia génekként a paradicsom elongációs faktor 1 alfa (SlEF1) [225], valamint a 18S rRNS [226] génjét választottuk (1. melléklet), melyek mindvégig konstans módon expresszálódtak a vizsgált szövetekben. A kapott eredményeket az adott időpont kezeletlen, VT értékére normalizáltuk.

\subsection{A sejthalál mértékének megállapítása}

A gyökércsúcsi sejtek relatív elektrolit-kieresztését (EL) Poór és mtsai. [98] által használt módszer alapján monitoroztuk. Egy grammnyi gyökércsúcsi szegmenst $15 \mathrm{~mL}$ dd. vízbe helyeztünk 2 órára, $25^{\circ} \mathrm{C}$-on. Ezt követően, meghatároztuk az áztató oldat konduktivitását (K1) egy vezetőképesség mérővel (OK-102/1 Radelkis, Budapest, Magyarország), majd $95{ }^{\circ} \mathrm{C}$-on 40 percig főztük a mintákat és meghatároztuk a teljes konduktivitást (K2). A gyökércsúcsok EL értékét a teljes konduktivitás \%-ában fejeztük ki: EL $(\%)=(\mathrm{K} 1 / \mathrm{K} 2)$ x 100.

A gyökércsúcsokban kialakuló DNS fragmentációt Kubis és mtsai. [227] általunk módosított módszere alapján detektáltuk. A gyökerek kétszer $50 \mathrm{~mL}$ dd. vizes mosását követően 100 mg csökércsúcsi szegmenst fagyasztottunk le, majd porítottunk el folyékony nitrogénben. 
Az így kapott porhoz hozzáadtunk $10 \mathrm{~mL}$ extrakciós puffert $(0,1 \mathrm{M} \mathrm{NaCl}, 2 \%$ SDS, $50 \mathrm{mM}$ TRIS-HCl [pH 9], 10 mM EDTA), majd inkubáltuk 10 percig szobahőmérsékleten. $300 \mathrm{~mL}$ fenol-kloroform 1:1 (v/v) elegy hozzáadása után 10 percig, $4{ }^{\circ} \mathrm{C}$-on, 3000 g-vel centrifugáltuk. A felülúszóval megismételtük a fenol-kloroformos lépést. 0,5 $\mathrm{mL}$ kloroform-izoamil alkoholt (24:1; v/v) adtunk az így kapott felülúszóhoz, majd ismételt centrifugálás következett (10 perc, $4{ }^{\circ} \mathrm{C}$-on, $3000 \mathrm{~g}$-vel). Az újonnan kapott felülúszót 3 órán keresztül inkubáltuk $550 \mathrm{~mL}$ izopropanol és $20 \mathrm{~mL}$ Na-acetát jelenlétében, amit a minták újbóli centrifugálása követett, $11300 \mathrm{~g}$-vel, $4{ }^{\circ} \mathrm{C}$-on, 10 percig. Az üledéket 70\%-os etanolban két alkalommal mostuk, illetve centrifugáltuk az utóbb megadott paraméterekkel. Végül, az üledéket a kiszárítását követően 20 mL TE pufferben (10 mM TRIS [pH 8,0]; $1 \mathrm{mM}$ EDTA) feloldottuk, majd 0,1 $\mathrm{mg} \mathrm{mL}^{-1}$ DNáz mentes RNázzal kezeltük az agaróz gélelektroforézis megkezdése előtt ( $80 \mathrm{mV}, 2$ óra).

\subsection{Statisztikai analízis}

Az adatok statisztikai analízisét a SigmaPlot 11 programmal végezük, Student-t teszt, illetve egyutas varianciaanalízist követő Duncan vagy Student-Newman-Keuls (SNK) teszt alkalmazásával, ahogy azt az ábrák aláírásaiban feltüntettük. A statisztikailag szignifikánsnak jelölt átlagok $P \leq 0,05$ valószínüségi szinten különböznek egymástól

\section{Eredmények}

\subsection{A gyökérzóna megnövekedett ACC tartalmának hatása paradicsomnövényekre, egyéb specifikus stresszfaktor alkalmazása nélkül}

\subsubsection{Az ET-termelésben, a növekedésben és az iontartalmakban bekövetkező változások exogén ACC kezelés hatására}

A gyökéren keresztül történő exogén ACC kezelés koncentrációtól és a növényi szövettől függően fokozza az etilénprodukciót paradicsomnövényekben (8. ábra). A 0,01 $\mu \mathrm{M}$ os ACC kezelés csupán marginális változásokat okozott a gyökér ET produkciójában, ugyanakkor az 1,0 $\mu \mathrm{M}$-os kezelés kissé, nem szignifikánsan emelte meg a gyökér ET emisszióját, ami csupán a 7. napon vált szignifikánssá. A $100 \mu \mathrm{M}$-os ACC viszont már az 1. naptól kezdve jelentős mértékben, tartósan fokozta az ET kibocsájtást a gyökérben. Érdekes módon, a két kisebb ACC koncentráció nem okozott szignifikáns ET emisszió növekedést a levélben sem (8. ábra), viszont a $100 \mu \mathrm{M}$ ACC a levélben is gyorsan megemelkedő ET emissziót váltott ki, ami a 7. napra a kezeletlen kontroll értékre esett vissza.

A gyökér friss- és száraz tömeg, valamint hossznövekedési paramétereiben egy ACC koncentráció sem okozott szignifikáns változást 7 nap alatt (2. táblázat). Annak ellenére, hogy az ET szabályozhatja a megnyúlásos növekedést, és a magasabb ACC koncentrációk hajtás frisstömeg gyarapodást indukáltak, ezek a változások nem bizonyultak szignifikánsnak (2. 
táblázat). Ugyanakkor a hajtások száraz tömeg értékeiben szignifikáns emelkedést tapasztaltunk a 0,01 és az 1,0 $\mu \mathrm{M}$-os, valamint csökkenést az egy hetes, $100 \mu \mathrm{M}$-os ACC kezelés hatására. Fontos megemlíteni, hogy a $100 \mu \mathrm{M}$-os ACC alkalmazása a levélnyelek extrém epinasztiáját eredményezte (2. melléklet)

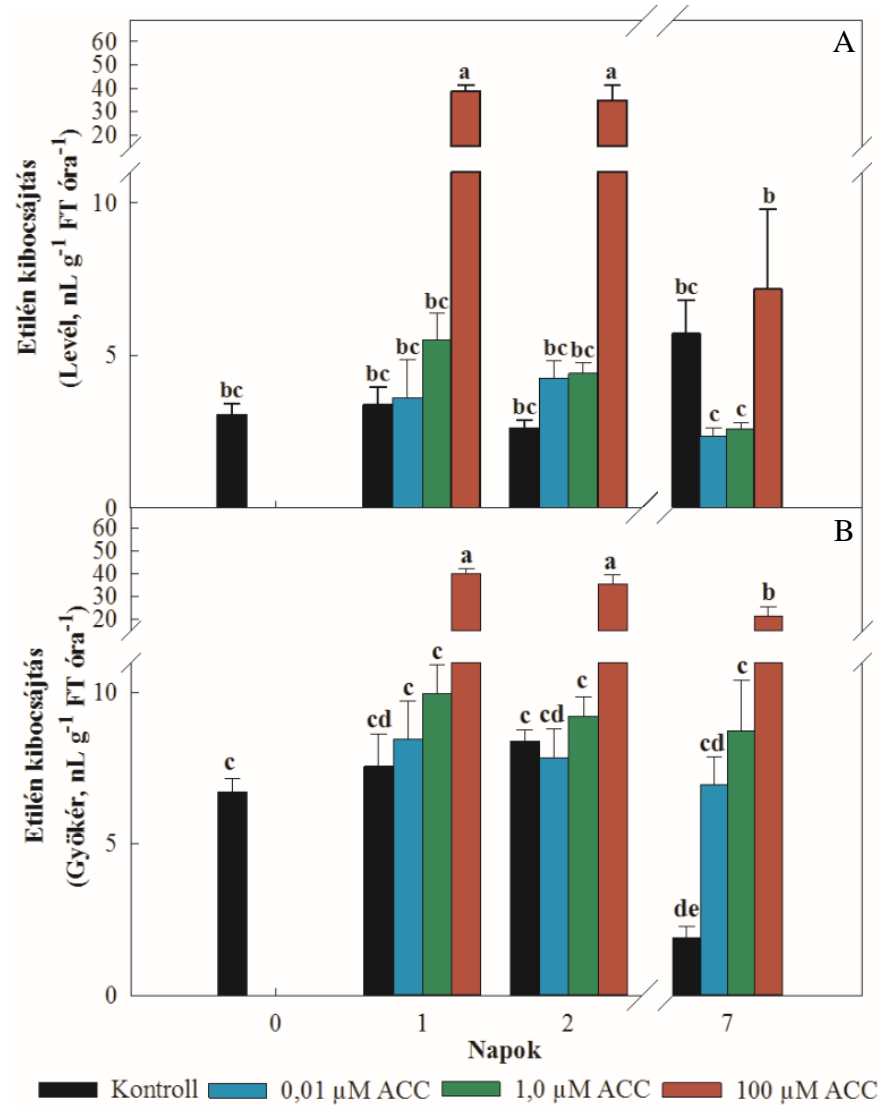

8. ábra 0,01, 1,0 és $100 \mu \mathrm{M}$ ACC kezelésnek kitett paradicsomlevelek (A) és -gyökerek (B) ET kibocsájtása. Kezeletlen kontroll: fekete oszlopok; $0,01 \mu \mathrm{M}$ ACC: kék oszlopok; 1,0 $\mu \mathrm{M}$ ACC: zöld oszlopok; $100 \mu \mathrm{M}$ ACC: piros oszlopok. Átlag + SE, $n=4$. A különbözö betüvel jelölt értékek szignifikáns különbségeket mutatnak a kezelések között $\mathrm{P} \leq 0,05$ szinten, (Duncan teszt), ns $=$ nem szignifikáns.

2. táblázat A növekedési paraméterek alakulása [hossz, friss- és száraz tömeg] 7 nappal a 0,01, 1,0 és $100 \mu \mathrm{M}$-os ACC kezeléseket követően, paradicsomgyökerekben és -hajtásokban

\begin{tabular}{|c|c|c|c|c|c|c|c|c|}
\hline & \multicolumn{4}{|c|}{ Gyökér } & \multicolumn{4}{|c|}{ Hajtás } \\
\hline & \multicolumn{8}{|c|}{$\mathrm{ACC}(\mu \mathrm{M})$} \\
\hline & Kontroll (0) & 0,01 & 1,0 & 100 & Kontroll (0) & 0,01 & 1,0 & 100 \\
\hline Hossz $(\mathrm{cm})$ & $22.83 \pm 0.7^{\mathrm{ns}}$ & $22.33 \pm 0.2^{\mathrm{ns}}$ & $23.67 \pm 1.1^{\mathrm{ns}}$ & $24.17 \pm 0.2^{\mathrm{ns}}$ & $21.25 \pm 0.7^{\mathrm{ns}}$ & $21.58 \pm 0.7^{\mathrm{ns}}$ & $22.00 \pm 0.6^{\mathrm{ns}}$ & $22.92 \pm 1.3^{\text {ns }}$ \\
\hline $\begin{array}{l}\begin{array}{l}\text { Friss tömeg } \\
(\mathrm{g})\end{array} \\
\end{array}$ & $5.68 \pm 0.2^{\mathrm{ns}}$ & $5.42 \pm 0.4^{\mathrm{ns}}$ & $4.98 \pm 0.2^{\mathrm{ns}}$ & $5.26 \pm 0.3^{\mathrm{ns}}$ & $12.11 \pm 1.2^{\mathrm{ns}}$ & $11.27 \pm 1.2^{\mathrm{ns}}$ & $13.41 \pm 1.5^{\mathrm{ns}}$ & $14.04 \pm 1.7^{\mathrm{ns}}$ \\
\hline $\begin{array}{l}\text { Száraz tömeg } \\
(\mathrm{g})\end{array}$ & $0.36 \pm 0.0^{\mathrm{ns}}$ & $0.34 \pm 0.0^{\mathrm{ns}}$ & $0.31 \pm 0.0^{\mathrm{ns}}$ & $0.30 \pm 0.0^{\mathrm{ns}}$ & $1.40 \pm 0.0^{\mathrm{c}}$ & $1.60 \pm 0.0^{\mathrm{a}}$ & $1.50 \pm 0.0^{\mathrm{b}}$ & $1.20 \pm 0.0^{\mathrm{d}}$ \\
\hline
\end{tabular}
teszt), ns $=$ nem szignifikáns.

Bár a gyökér $\mathrm{K}^{+}$tartalmában nem tapasztaltunk szignifikáns, exogén ACC okozta változást a kísérlet 7. napján, szignifikáns $\mathrm{Na}^{+}$akkumuláció növekedést detektáltunk az 1,0 és a $100 \mu \mathrm{M}$-os ACC kezelés hatására (3. táblázat). A kifejlett, nem öregedő levelek esetében szignifikáns $\mathrm{K}^{+}$deficitet detektáltunk a 0,01 és az $1,0 \mu \mathrm{M}$-os ACC koncentráció hatására 7 nap elteltével, továbbá jelentős mértékü $\mathrm{Na}^{+}$felhalmozódást a legnagyobb ACC koncentráció 
esetében (3. táblázat). Ezek alapján elmondható, hogy a gyökerek hosszabb intervallumú kitettsége $100 \mu \mathrm{M}$ ACC-nek csökkent $\mathrm{K}^{+} / \mathrm{Na}^{+}$arányhoz vezetett mindkét vizsgált növényi részben (3. táblázat).

3. táblázat $\mathrm{A}$ makroelem- és vastartalmak alakulása ( $\mu$ mol g-1 száraz tömeg) 7 nappal a $0,01,1,0$ és $100 \mu \mathrm{M}$-os ACC kezeléseket követően, paradicsomgyökerekben és -levelekben

\begin{tabular}{|c|c|c|c|c|c|c|c|c|}
\hline & \multicolumn{4}{|c|}{ Gyökér } & \multicolumn{4}{|c|}{ Levél } \\
\hline & \multicolumn{8}{|c|}{$\operatorname{ACC}(\mu \mathrm{M})$} \\
\hline & Kontroll (0) & 0,01 & 1,0 & 100 & Kontroll (0) & 0,01 & 1,0 & 100 \\
\hline $\mathrm{Na}^{+}$ & $75,8 \pm 3,5^{\mathrm{c}}$ & $74,27 \pm 4,1^{\mathrm{c}}$ & $88,1 \pm 3,1^{b}$ & $111,7 \pm 2,1^{\mathrm{a}}$ & $51,3 \pm 1,23^{\mathrm{b}}$ & $40,1 \pm 2,8^{b}$ & $44,4 \pm 4,6^{\mathrm{b}}$ & $63,7 \pm 4,8^{\mathrm{a}}$ \\
\hline \multirow[t]{2}{*}{$\overline{\mathrm{K}^{+}}$} & 949,9 & 1000,9 & 1003,1 & 1054,8 & 674,3 & 489,6 & 500,7 & 616,0 \\
\hline & $\pm 91,6^{\mathrm{ns}}$ & $\pm 44,7^{\mathrm{ns}}$ & $\pm 104,4^{\mathrm{ns}}$ & $\pm 35,3^{\mathrm{ns}}$ & $\pm 19,4^{\mathrm{a}}$ & $\pm 26,1^{\mathrm{b}}$ & $\pm 16,9^{\mathrm{b}}$ & $\pm 24,7^{\mathrm{a}}$ \\
\hline \multirow[t]{2}{*}{$\overline{\mathrm{Ca}^{2+}}$} & 148,4 & 191,37 & 171,1 & 147,7 & 411,3 & 315,9 & 325,7 & 394,1 \\
\hline & $\pm 9,0^{\mathrm{ns}}$ & $\pm 13,8^{\text {ns }}$ & $\pm 29,9^{\text {ns }}$ & $\pm 4,9^{\text {ns }}$ & $\pm 38,2^{\mathrm{ns}}$ & $\pm 27,0^{\text {ns }}$ & $\pm 34,5^{\mathrm{ns}}$ & $\pm 13,2^{\mathrm{ns}}$ \\
\hline \multirow[t]{2}{*}{$\overline{\mathrm{Mg}^{2+}}$} & 187,1 & 190,21 & 189,5 & 293,3 & 173,9 & 138,6 & 140,2 & 173,9 \\
\hline & $\pm 16,1^{\mathrm{b}}$ & $\pm 15,7^{\mathrm{b}}$ & $\pm 1,7^{\mathrm{b}}$ & $\pm 11,1^{\mathrm{a}}$ & $\pm 12,5^{\mathrm{a}}$ & $\pm 2,9^{\mathrm{b}}$ & $\pm 12,1^{\mathrm{b}}$ & $\pm 9,6^{\mathrm{a}}$ \\
\hline$\overline{\mathrm{Fe}^{2+}}$ & $4,8 \pm 0,2^{\mathrm{c}}$ & $6,2 \pm 0,2^{b}$ & $7,3 \pm 0,5^{\mathrm{a}}$ & $6,1 \pm 0,2^{\mathrm{b}}$ & $1,8 \pm 0,1^{\mathrm{ns}}$ & $1,5 \pm 0,1^{\mathrm{ns}}$ & $1,4 \pm 0,1^{\mathrm{ns}}$ & $1,9 \pm 0,2^{\mathrm{ns}}$ \\
\hline$\overline{\mathrm{K}^{+} / \mathrm{Na}^{+}}$ & $12,5 \pm 0,6^{\mathrm{a}}$ & $13,5 \pm 0,5^{\mathrm{a}}$ & $11,4 \pm 0,5^{\mathrm{a}}$ & $9,4 \pm 0,4^{\mathrm{b}}$ & $13,1 \pm 0,6^{\mathrm{a}}$ & $12,2 \pm 1,0^{\mathrm{a}}$ & $11,3 \pm 0,9^{\mathrm{a}}$ & $9,7 \pm 0,8^{\mathrm{b}}$ \\
\hline
\end{tabular}

Ezzel egyidőben, a $100 \mu \mathrm{M}$-os ACC $\mathrm{Mg}^{2+}$ felhalmozódást okozott a gyökérben (3. táblázat). Annak ellenére, hogy a két kisebb ACC koncentráció szignifikánsan csökkentette a levelek $\mathrm{Mg}^{2+}$ akkumulációját, a $100 \mu \mathrm{M}-\mathrm{os}$ ACC nem befolyásolta azt jelentősen.

A szövetek $\mathrm{Ca}^{2+}$ tartalmában nem kaptunk szignifikáns változást a kísérlet során. $\mathrm{Az}$ exogén ACC szignifikánsan fokozta a gyökerek $\mathrm{Fe}^{2+}$ szintjét, míg a levelekben a kisebb koncentrációk enyhe, marginális $\mathrm{Fe}^{2+}$ csökkenést okoztak (3. táblázat).

\subsubsection{Exogén ACC kezelés okozta változások a gyökércsúcsok, valamint a kifejlett, nem öregedő levelek ROS és RNF produkciójában}

A járulékos gyökerek apikális régiójában a $\mathrm{H}_{2} \mathrm{O}_{2}$, illetve a $\mathrm{NO}$ felhalmozódás hangsúlyos változása figyelhető meg (9. ábra). A $100 \mu \mathrm{M}$ ACC egy hét alatt drasztikusan megemelte a gyökércsúcsok $\mathrm{H}_{2} \mathrm{O}_{2}$ tartalmát, miközben a $\mathrm{NO}$ akkumulációra nem volt hatással.

A 0,01 és az 1,0 $\mu \mathrm{M}$-os ACC viszont jelentősen csökkentette a gyökércsúcsok NO tartalmát. $\mathrm{A}_{2}{ }^{*-}$ termelődés a túl magas standard mérési hiba értékek miatt nem bizonyult szignifikánsnak és a gyökércsúcsok $\mathrm{ONOO}^{-}$produkciója sem változott a 7. napon (9. ábra).

A gyökér környezetében megemelkedett ACC koncentráció enyhe, de szignifikáns mértékü $\mathrm{H}_{2} \mathrm{O}_{2}$ akkumulációt okozott a levelekben 7 napot követően, azonban a $\mathrm{O}_{2}{ }^{\circ}$, a $\mathrm{NO}$ és a ONOO- produkció csupán a $100 \mu \mathrm{M}$-os ACC kezelés hatására mutatott szignifikáns emelkedést, noha ez a növekmény a $\mathrm{ONOO}^{-}$esetében kevésbé volt kifejezett, mint a NO akkumulációban történő változás. Az 1,0 $\mu \mathrm{M}$-os ACC alkalmazása viszont szignifikánsan gátolta a kifejlett, nem öregedő levelek NO termelődését (10. ábra). 


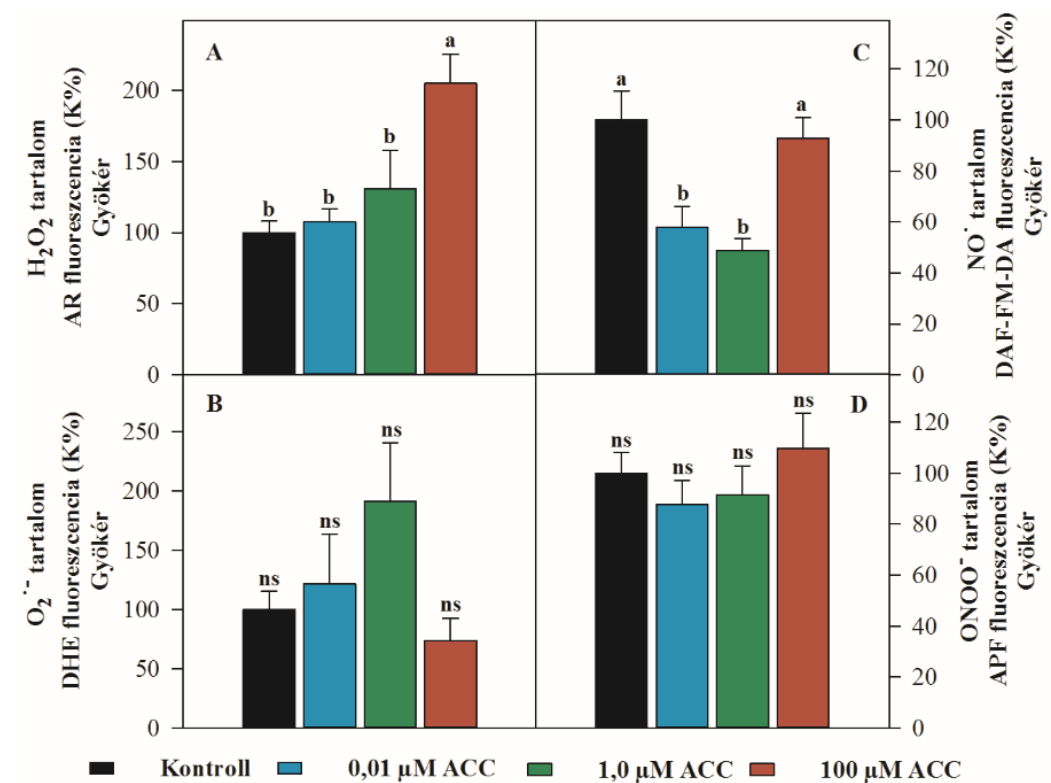

9. ábra $\mathrm{A} \mathrm{H}_{2} \mathrm{O}_{2}$ (A), a $\mathrm{O}_{2}^{-}{ }^{-}$(B), a $\mathrm{NO}$ (C) és a $\mathrm{ONOO}^{-}$(D) tartalmakban bekövetkező változások 1 hetes, 0 (fekete oszlopok), 0,01 (kék oszlopok), 1,0 (zöld oszlopok) és $100 \mu \mathrm{M}$ (piros oszlopok) ACC kezelésnek kitett paradicsomnövények járulékos gyökereinek apikális szegmensében. A különbözö molekulákra specifikus festékek fluoreszcencia intenzitása a kontroll értékek \%-ában került ábrázolásra. Átlag $+\mathrm{SE}, \mathrm{n}=16$. A különböző betűvel jelölt értékek szignifikáns különbségeket mutatnak a kezelések között $\mathrm{P} \leq 0,05$ szinten, (Duncan teszt).

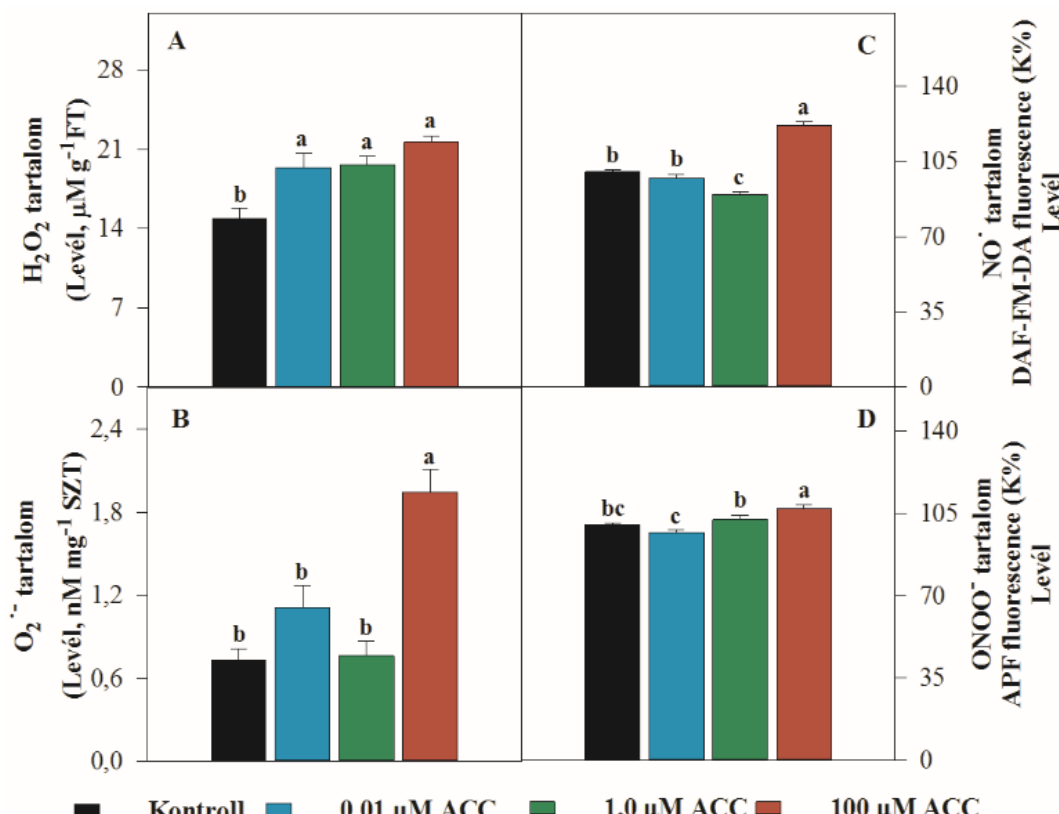

10. ábra $\mathrm{A}_{2} \mathrm{O}_{2}(\mathrm{~A})$, a $\mathrm{O}_{2}{ }^{--}(\mathrm{B})$, a $\mathrm{NO}(\mathrm{C})$ és a $\mathrm{ONOO}^{-}$(D) tartalmakban bekövetkező változások 1 hetes, 0 (fekete oszlopok), 0,01 (kék oszlopok), 1,0 (zöld oszlopok) és $100 \mu \mathrm{M}$ (piros oszlopok) ACC kezelésnek kitett paradicsomnövények leveleiben. A NO és a $\mathrm{ONOO}^{-}$specifikus festékek fluoreszcencia intenzitása a kontroll értékek \%-ában került ábrázolásra. Átlag + SE, n=16. A különböző betűvel jelölt értékek szignifikáns különbségeket mutatnak a kezelések között $\mathrm{P} \leq 0,05$ szinten, (Duncan teszt).

\subsubsection{A gyökérzónában kialakuló ACC többlet-indukálta változások a paradicsomnövények fotoszintetikus aktivitásában}

A sztómák záródásának mértéke meghatározza a párologtatás mértékét, valamint a gázcsere, ezen belül a $\mathrm{CO}_{2}$ felvételének lehetőségét is. A 0,01 és az 1,0 $\mu \mathrm{M}$-os ACC koncentrációk csupán marginális változásokat okoztak a $\mathrm{g}_{\mathrm{sw}}$ paraméterben a kezelés alatt, viszont a $100 \mu \mathrm{M}$-os ACC expozíció hatására a levelek csaknem 50\%-os $\mathrm{g}_{\mathrm{sw}}$ redukciót szenvedtek el 24 óra múltán, mely a kontrollhoz képest szignifikánsan alacsonyabb maradt a 2. és 5. napok között (11. ábra, A). 
A $\mathrm{C}_{\mathrm{i}} / \mathrm{C}_{\mathrm{a}}$ a $\mathrm{g}_{\mathrm{sw}}$-hez hasonló tendenciát mutatott az első 2 napon, azonban néhány különbség megfigyelhető a 3. naptól (11. ábra, B). A $100 \mu \mathrm{M}$-os ACC kezelést követő 24 óra elteltével szignifikáns csökkenés látható a $\mathrm{C}_{\mathrm{i}} / \mathrm{C}_{\mathrm{a}}$ paraméterben, majd érdekes módon, a 3. napon a kontroll szintre történő visszatérést tapasztaltunk. Ezt egy ismételt szignifikáns, a 4. napon megfigyelhető tranziens csökkenés, majd a kontroll érték felé közelítés követte az 5. naptól.

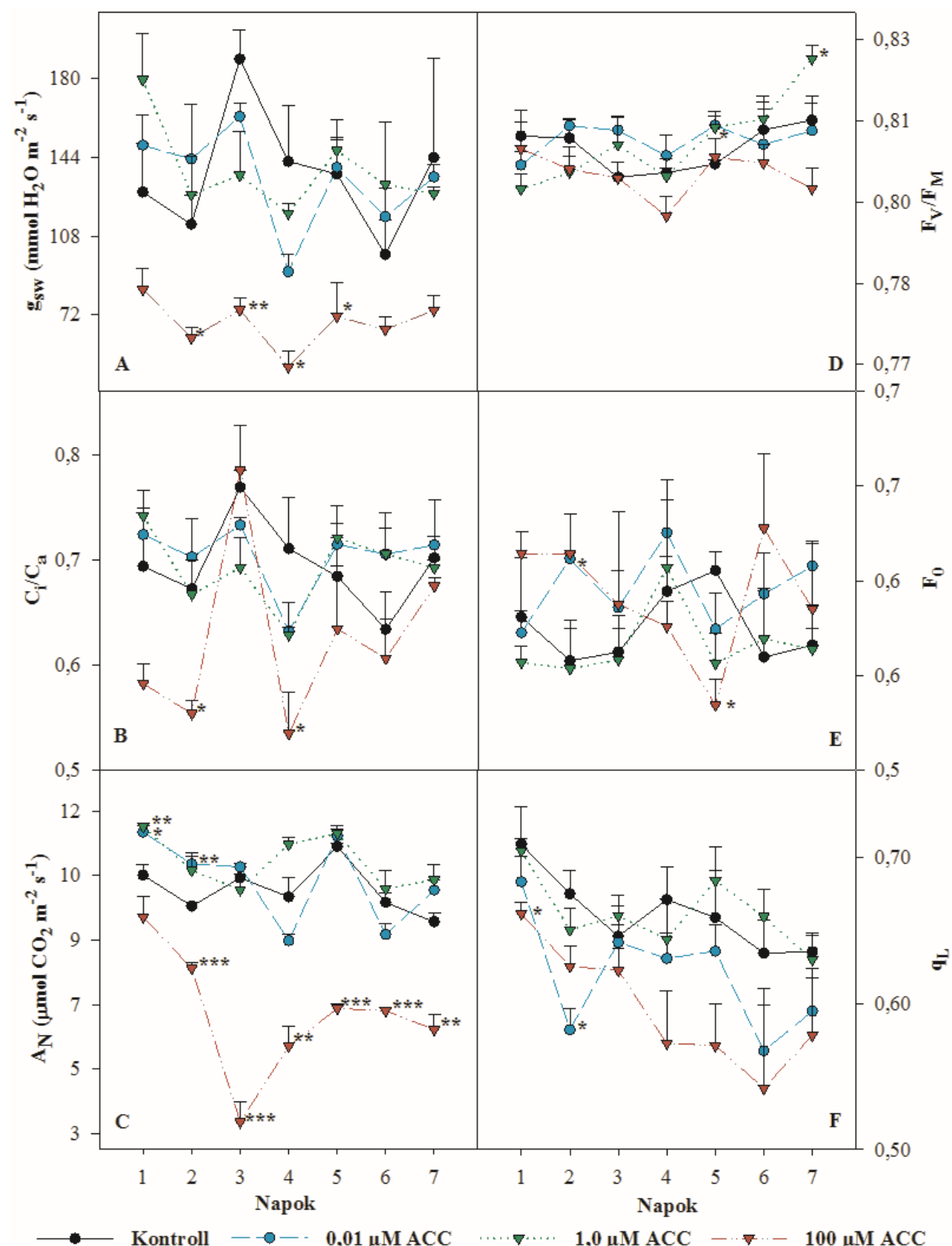

11. ábra $\mathrm{A} \mathrm{CO}_{2}$ asszimiláció és a kapcsolódó paraméterek $(\mathrm{A}, \mathrm{B}, \mathrm{C})$ illetve a PSII állapotára $(\mathrm{D}, \mathrm{E}, \mathrm{F})$ vonatkozó klorofill $a$ fluoreszcencia paraméterek időbeni változásai 7 napos, $0(\bullet), 0,01(0), 1,0(\nabla)$ és $100 \mu \mathrm{M}(\boldsymbol{\nabla})$ ACC kezelésnek kitett paradicsomnövények leveleiben. A: A sztómák vízgőzvezető képessége, $\mathrm{g}_{\mathrm{sw}}$; $\mathrm{B}$ : az intercelluláris és az atmoszférikus $\mathrm{CO}_{2} \mathrm{koncentráció}$ aránya, $\mathrm{C}_{\mathrm{i}} / \mathrm{C}_{\mathrm{a}}$; $\mathrm{C}$ : a nettó $\mathrm{CO}_{2}$ asszimilációs ráta, $\mathrm{AN}_{\mathrm{N}}$ D: a PSII maximális kvantumhatásfoka sötétadaptált levelekben, $\mathrm{F}_{\mathrm{V}} / \mathrm{F}_{\mathrm{M}}, \mathrm{E}$ : a sötétadaptált levelek minimális fluoreszcenciája, $\mathrm{F}_{0}$; F: a PSII reakciócentrumok nyitott állapotú frakciója, qL. Átlag + SE, $n=3(\mathrm{~A}$, $\mathrm{B}, \mathrm{C})$ és $\mathrm{n}=4(\mathrm{D}, \mathrm{E}, \mathrm{F}) . \mathrm{A}^{*},{ }^{* *}$ és ${ }^{* * *}$ jelekkel jelölt adatok szignifikáns eltéréseket mutatnak az adott nap kezeletlen kontroll értékeihez viszonyítva $\mathrm{P} \leq 0,05, \mathrm{P} \leq 0,01$ és $\mathrm{P} \leq 0,001$ szinteken (Student's $\mathrm{t}$ teszt).

A két kisebb ACC koncentráció számottevően növelte az $A_{N}$ mértékét 24 illetve 48 órát követően (11. ábra, C). Ezzel szemben, a $100 \mu \mathrm{M}-$ os $\mathrm{ACC}$ az $\mathrm{A}_{\mathrm{N}}$ szignifikáns, konstans 
csökkenését okozta a kísérlet elején. Egy, a 3. napon detektált minimum értéket követően rövid normalizálódási szakasz figyelhető meg, majd az $A_{N}$ a 6. naptól ismét csökkent. A kísérlet során nem tapasztaltunk jelentős változást az $\mathrm{F}_{\mathrm{V}} / \mathrm{F}_{\mathrm{M}}(11$. ábra, $\mathrm{D})$ és az $\mathrm{F}_{0}$ paraméterekben (11. ábra, E). Érdekes módon, a 0,01 és a $100 \mu \mathrm{M}$-os ACC is csökkentette a qL-t, azonban ez sokkal kifejezettebb volt a magasabb koncentráció esetében (11. ábra, F).

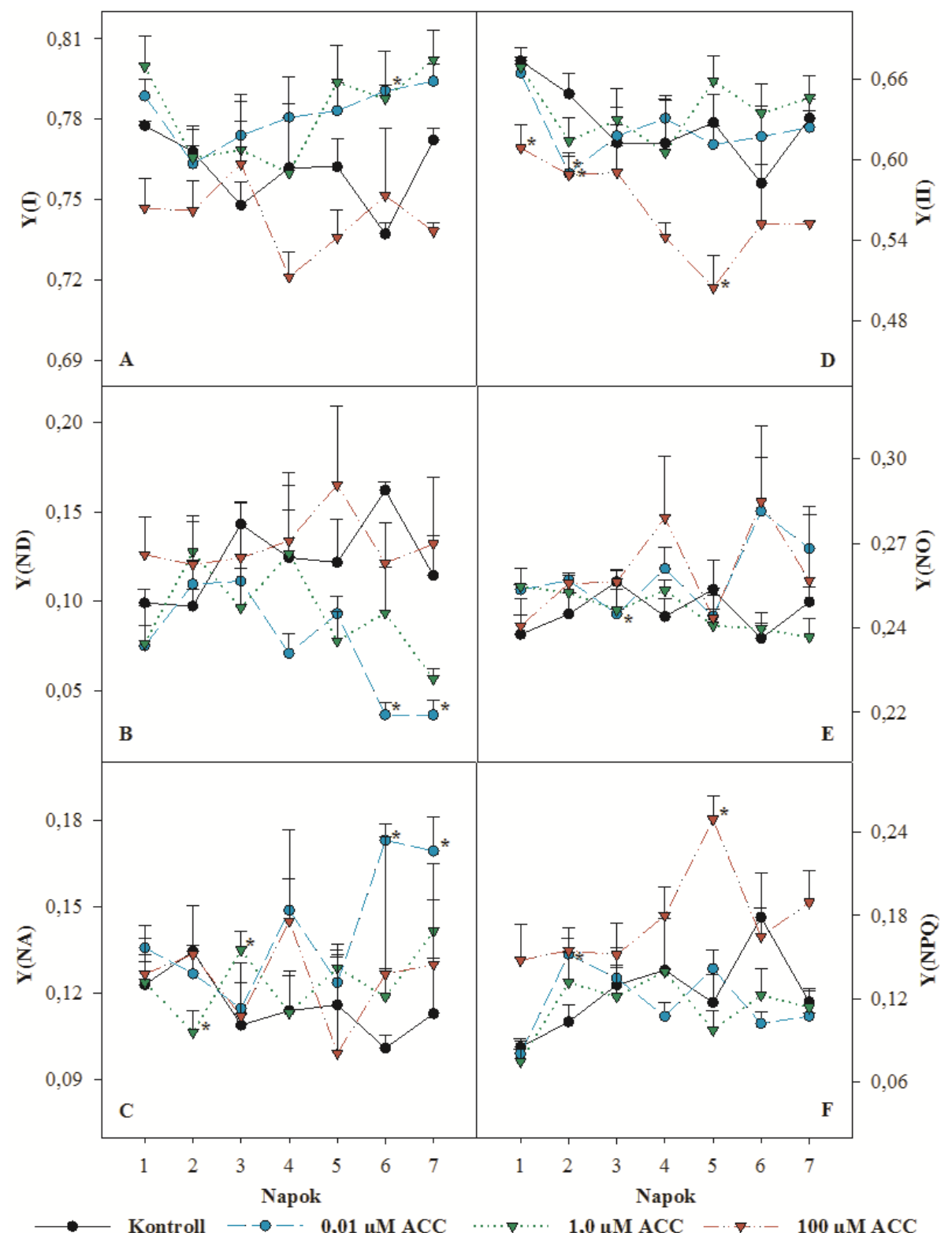

12. ábra $A P 700$ abszorbancia változások $(A, B, C)$ és a korofill $a$ fluoreszcencia indukciós paraméterek $(\mathrm{D}, \mathrm{E}, \mathrm{F})$ időbeni változásai 7 napos0 $(\bullet), 0,01(0), 1,0(\nabla)$ és $100 \mu \mathrm{M}(\boldsymbol{\nabla})$ ACC kezelésnek kitett paradicsomnövények leveleiben. Átlag + SE, 4. A: a PSI fotokémiai kvantumhatásfoka fényadaptált levelekben, Y(I); B: a PSI donor oldali limitációjából fakadó nem-fotokémiai kioltás kvantumhatásfoka, Y(ND); C: a PSI akceptor oldali limitációjából fakadó nem-fotokémiai kioltás kvantumhatásfoka, Y(NA); D: a PSII effektív kvantumhatásfoka, Y(II); E: a nem-szabályozott energia disszipáció kvantumhatásfoka, Y(NO); F: szabályozott (fényaktivált) energia disszipáció kvantumhatásfoka, Y(NPQ). A * jellel jelölt adatok szignifikáns eltéréseket mutatnak az adott nap kezeletlen kontroll értékeihez viszonyítva $\mathrm{P} \leq 0,05$ szinten (Student's t teszt)

A tápoldat ACC tartalmának kisebb megemelése $(0,01$ és $1,0 \mu \mathrm{M})$ a $\mathrm{Y}(\mathrm{I})$ enyhe, lépcsőzetes növekedését okozta (12. ábra, A), mely szignifikáns eltért a kontrolltól az 6. napon. Meglepő módon, a Y(I) értékének megváltozását ebben az esetben nem követte a Y(II) 
kontrollhoz viszonyított tendenciális növekedése (12. ábra, D). A $100 \mu \mathrm{M}$-os ACC kezelés a Y(II) szignifikáns csökkenését okozta az 1. a 2. és az 5. napon.

A Y(ND) és Y(NA) paraméterekben apróbb fluktuációk figyelhetők meg a kezelési periódus elején. Fontos megemlíteni azonban, hogy a $0,01 \mu \mathrm{M}$-os ACC koncentráció (és enyhébb mértékben az $1 \mu \mathrm{M}$-os is) szignifikánsan megváltoztatta a PSI nem fotokémiai kioltási profilját donor-oldal dominánsról akceptor-oldal dominánsra az 5. naptól, méghozzá nettó Y(I) limitáció nélkül (12. ábra, B, C). A 100 M ACC-nek történő kitettség Y(II) gátló hatása az 5. napig erősödő $\mathrm{Y}(\mathrm{NPQ})$, illetve marginális, ingadozó növekményeket mutató Y(NO) paraméterekkel társul (12. ábra, E, F). Bár a 0,01 $\mu \mathrm{M}$ ACC is okozott tranziens, szignifikáns Y(II) redukciót és Y(NPQ) növekedést a 2. napon, a kisebb ACC koncentrációk hatására később csupán marginális változások voltak megfigyelhetők a Y(NO) és Y(NPQ) értékekben.

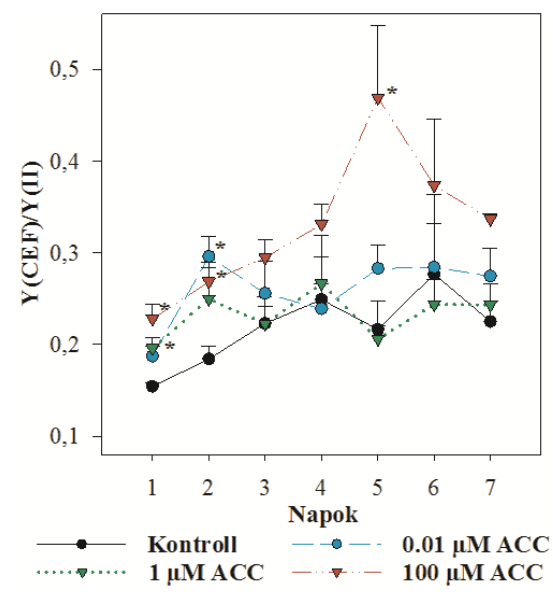

13. ábra A PSI körüli ciklikus elektronáramlás kvantumhatásfok-többletének időbeni változásai 7 napos, $0(\bullet), 0,01(0), 1,0(\nabla)$ és $100 \mu \mathrm{M}(\boldsymbol{\nabla})$ ACC kezelésnek kitett paradicsomnövények leveleiben. Átlag + SE, n = 4. A* jellel jelölt adatok szignifikáns eltéréseket mutatnak az adott nap kezeletlen kontroll értékeihez viszonyítva $\mathrm{P} \leq 0,05$ szinten (Student’s t teszt)

A Y(CEF)/Y(II) arány vizsgálatából kiderült, hogy a 0,01 és az 1,0 $\mu \mathrm{M}$-os ACC kezelések szignifikánsan növelték a CEF-PSI mértékét az 1. és a 2. napon, azonban a $100 \mu \mathrm{M}$ os ACC expozíció a CEF sokkal hangsúlyosabb emelkedését okozta. Ez az 5. napon érte el a maximumát, melyet érdekes módon egy jelentős visszaesés követett (13. ábra).

4. táblázat A paradicsomlevelek klorofill $a$ és $b(\mathrm{Kl} a \mathrm{Kl} b)$ valamint az összkarotinoid (Kar) tartalmában ( $\mathrm{mg} \mathrm{g}^{-1}$ friss tömeg) bekövetkező változások 7 nappal a $0,01,1,0$ és $100 \mu \mathrm{M}$-os ACC kezeléseket követöen.

\begin{tabular}{|c|c|c|c|c|}
\hline & $\begin{array}{c}\text { Kontroll } \\
(0 \mu \mathrm{M} \text { ACC })\end{array}$ & $\begin{array}{c}0,01 \mu \mathrm{M} \\
\mathrm{ACC}\end{array}$ & $\begin{array}{c}1,0 \mu \mathrm{M} \\
\mathrm{ACC}\end{array}$ & $\begin{array}{c}100 \mu \mathrm{M} \\
\mathrm{ACC}\end{array}$ \\
\hline $\mathrm{Kl} a$ & $1,69 \pm 0,06^{\mathrm{ns}}$ & $1,78 \pm 0,03^{\mathrm{ns}}$ & $1,89 \pm 0,10^{\mathrm{ns}}$ & $1,56 \pm 0,18^{\mathrm{ns}}$ \\
\hline $\mathrm{K} 1 b$ & $0,62 \pm 0,02^{\mathrm{ns}}$ & $0,63 \pm 0,02^{\mathrm{ns}}$ & $0,70 \pm 0,05^{\mathrm{ns}}$ & $0,58 \pm 0,07^{\mathrm{ns}}$ \\
\hline $\mathrm{Kl} a+b$ & $2,31 \pm 0,08^{\mathrm{ns}}$ & $2,41 \pm 0,04^{\mathrm{ns}}$ & $2,59 \pm 0,14^{\mathrm{ns}}$ & $2,14 \pm 0,25^{\mathrm{ns}}$ \\
\hline Kar & $0,44 \pm 0,01^{\mathrm{ab}}$ & $0,46 \pm 0,01^{\mathrm{a}}$ & $0,48 \pm 0,02^{\mathrm{a}}$ & $0,39 \pm 0,03^{b}$ \\
\hline
\end{tabular}


Az oxidatív stresszre utaló körülmények ellenére, nem találtunk számottevő eltérést a levelek klorofill- és karotinoidtartalmában egy hét elteltével, kivéve a $100 \mu \mathrm{M}$-os ACC kezelés esetét, ahol a karotinoidok enyhe, de szignifikáns csökkenése figyelhető meg (4. táblázat).

A 0,01 és az 1,0 $\mu \mathrm{M}$-os ACC kezelések a kontrollhoz képest szignifikánsan növelték a gyökerek összcukor tartalmát a 7. napra (5. táblázat). Mind a fruktóz, mind a glükóz akkumuláció ACC általi serkentését megfigyelhettük a gyökérben, azonban a fruktóz tartalom háromszorosa volt a glükózénak. A 1,0 és a $100 \mu \mathrm{M}$-os ACC koncentráció is csökkentette a gyökerek szacharóz felhalmozását. Az exogén ACC expozíció növelte a gyökérszövetek szorbitol tartalmát a 7. napra, kivéve a $100 \mu \mathrm{M}$-os ACC kezelés esetét.

5. táblázat Az összcukor-tartalom ( $\mathrm{mg} \mathrm{g}^{-1}$ friss tömeg) és a különböző típusú cukrok és a szorbitol ( $\mu$ mol $\mathrm{g}^{-1}$ friss tömeg) akkumulációja 7 nappal a 0,01, 1,0 és $100 \mu \mathrm{M}$-os ACC kezeléseket követően.

\begin{tabular}{lccc|c|cccc}
\hline & \multicolumn{9}{c}{ Gyökér } & \multicolumn{4}{c}{ Levél } \\
\cline { 2 - 9 } & Kontroll (0) & 0,01 & 1,0 & 100 & Kontroll (0) & 0,01 & 1,0 & 100 \\
\hline Összcukor & $55,8 \pm 2,3^{\mathrm{b}}$ & $74,0 \pm 2,8^{\mathrm{a}}$ & $75,0 \pm 1,1^{\mathrm{a}}$ & $57,9 \pm 2,2^{\mathrm{b}}$ & $85,7 \pm 5,0^{\mathrm{b}}$ & $95,6 \pm 0,7^{\mathrm{ab}}$ & $106,5 \pm 4,0^{\mathrm{a}}$ & $91,0 \pm 3,4^{\mathrm{b}}$ \\
Glükóz & $3,74 \pm 0,10^{\mathrm{d}}$ & $8,91 \pm 0,05^{\mathrm{a}}$ & $7,80 \pm 0,04^{\mathrm{b}}$ & $5,81 \pm 0,04^{\mathrm{c}}$ & $8,84 \pm 0,01^{\mathrm{c}}$ & $12,8 \pm 0,2^{\mathrm{b}}$ & $14,3 \pm 0,2^{\mathrm{a}}$ & $13,5 \pm 0,5^{\mathrm{b}}$ \\
Fruktóz & $13,0 \pm 0,3^{\mathrm{c}}$ & $19,9 \pm 0,1^{\mathrm{a}}$ & $20,2 \pm 0,2^{\mathrm{a}}$ & $14,5 \pm 0,2^{\mathrm{b}}$ & $17,7 \pm 0,1^{\mathrm{c}}$ & $20,0 \pm 0,3^{\mathrm{b}}$ & $21,7 \pm 0,3^{\mathrm{a}}$ & $19,8 \pm 0,4^{\mathrm{b}}$ \\
Szacharóz & $2,66 \pm 0,33^{\mathrm{a}}$ & $3,12 \pm 0,10^{\mathrm{a}}$ & $1,08 \pm 0,18^{\mathrm{c}}$ & $1,91 \pm 0,12^{\mathrm{b}}$ & $1,34 \pm 0,18^{\mathrm{b}}$ & $3,07 \pm 0,28^{\mathrm{a}}$ & $2,04 \pm 0,27^{\mathrm{ab}}$ & $1,58 \pm 0,52^{\mathrm{b}}$ \\
Szorbitol & $0,09 \pm 0,01^{\mathrm{b}}$ & $0,14 \pm 0,09^{\mathrm{a}}$ & $0,15 \pm 0,02^{\mathrm{a}}$ & $0,08 \pm 0,01^{\mathrm{b}}$ & $0,27 \pm 0,013^{\mathrm{b}}$ & $0,41 \pm 0,02^{\mathrm{a}}$ & $0,46 \pm 0,02^{\mathrm{a}}$ & $0,45 \pm 0,02^{\mathrm{a}}$ \\
\hline
\end{tabular}

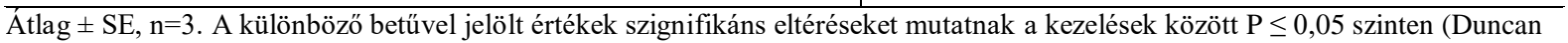
teszt).

A levelek összcukor, glükóz és fruktóz akkumulációjában a gyökéréhez hasonló tendenciákat figyeltünk meg, azzal a kivétellel, hogy a levélben a fruktóztartalom csupán körülbelül kétszerese volt a glükózénak (5. táblázat). A $0,01 \mu \mathrm{M}$-os ACC fokozta a levelek szacharóz koncentrációját is. Az exogén ACC a levelek szorbitol tartalmát is növelte a 7. napra.

\subsection{Paradicsomgyökerek só-indukálta, etilén függő válaszai}

\subsubsection{Az ET jelátvitel szerepe a gyökerek sótoleranciájában, ROF és RNF produkciójában, ET receptor mutáns, Never ripe paradicsomnövényekben.}

Az ET-érzékelésnek a gyökér sóstressz-válaszaiban betöltött szerepét vizsgálva meghatároztuk a gyökércsúcsok ET kibocsájtását a 100 mM-os és a 250 mM-os NaCl kezelést követően.

Mindkét sókoncentráció növelte az ET emissziót a $N r$ mutáns gyökerek apikális szegmensében (14. ábra). A szubletális sókoncentráció mindkét genotípus ET produkcióját megnövelte a 6. órától. A $250 \mathrm{mM}-\mathrm{os} \mathrm{NaCl}$ kezelés 24. óráját követően a $\mathrm{VT}$ és $\mathrm{Nr}$ gyökércsúcsok ET produkciója is szignifikánsan csökkent.

A sókezelések hatására, már 1 óra elteltével $\mathrm{O}_{2}{ }^{*-}$ felhalmozódást tapasztaltunk mindkét genotípus gyökércsúcsában, ami viszont szignifikánsan magasabb értéket ért el a $\mathrm{Nr}$ mutánsban (15. ábra, A). $100 \mathrm{mM} \mathrm{NaCl}$ jelenlétében, 6 óra elteltével a $\mathrm{O}_{2}{ }^{\circ-}$ produkció csökkent a VT gyökerek apikális régiójában ellentétben a $\mathrm{Nr}$ mutánsokéval. Ugyanakkor, $250 \mathrm{mM} \mathrm{NaCl}$ 
magas, maradandó $\mathrm{O}_{2}{ }^{*}$ felhalmozódást indukált a VT és a $\mathrm{Nr}$ gyökércsúcsokban, bár az utóbbiak esetében ismét magasabb értékeket detektáltunk 1, illetve 6 óra elteltével.

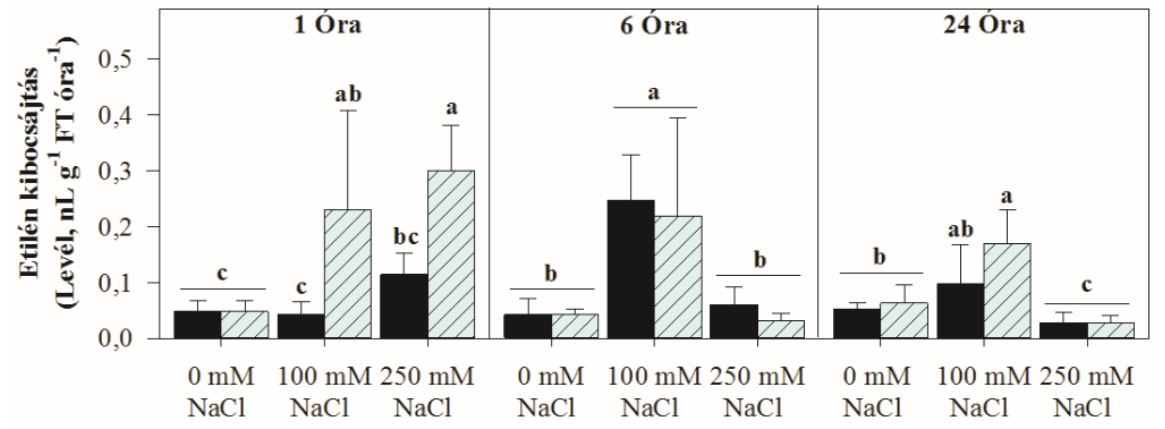

14. ábra Az ET produkció VT (fekete oszlopok) és Nr mutáns (ferdecsíkos, halványkék oszlopok) paradicsomnövények járulékos gyökereinek apikális régiójában a 100 ill. $250 \mathrm{mM}$-os $\mathrm{NaCl}$ kezelés 1., 6. és 24. óráját követően. Átlag $+\mathrm{SD}, \mathrm{n}=6$. A különbözö betűvel jelölt értékek szignifikáns különbségeket mutatnak a kezelések között, az adott időpontban $\mathrm{P} \leq 0,05$ szinten (Duncan teszt).

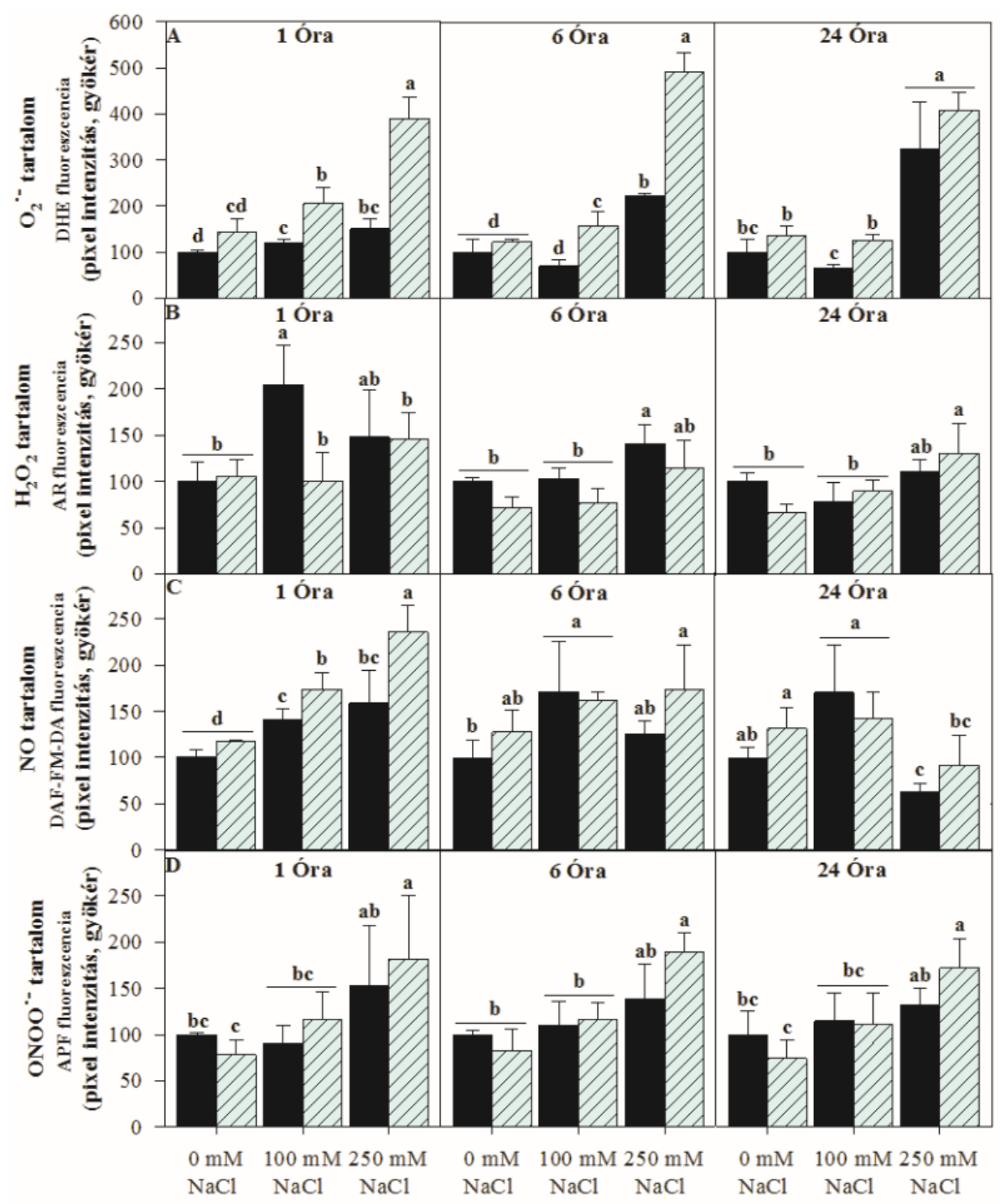

15. ábra $\mathrm{A} \mathrm{O}_{2}{ }^{-}$(A), a $\mathrm{H}_{2} \mathrm{O}_{2}(\mathrm{~B})$, a $\mathrm{NO}(\mathrm{C})$ és a $\mathrm{ONOO}^{-}$(D) akkumuláció VT (fekete oszlopok) és $N r$ mutáns (ferdecsíkos, halványkék oszlopok) paradicsomnövények járulékos gyökereinek apikális régiójában a 100 ill. $250 \mathrm{mM}$-os NaCl kezelés 1., 6. és 24 . óráját követően. A különböző molekulákra specifikus festékek fluoreszcencia intenzitása a kontroll értékek \%-ában került ábrázolásra. Átlag $+\mathrm{SD}, \mathrm{n}=6$. A különböző betủvel jelölt értékek szignifikáns különbségeket mutatnak a kezelések között, az adott időponban $\mathrm{P} \leq 0,05$ szinten (Duncan teszt). 
A só expozíció 1. óráját követően csupán a VT gyökércsúcsok $\mathrm{H}_{2} \mathrm{O}_{2}$ mennyisége emelkedett meg (15. ábra, B), a $N r$ növényekben ez a változás az időben eltolva és csak a 250 mM-os $\mathrm{NaCl}$ kezelés esetében volt megfigyelhető. Míg a letális $\mathrm{NaCl}$ koncentráció tranziens NO akkumulációt indukált, a szubletális stressz minden időpontban megemelte a NO szinteket a VT és $N r$ gyökércsúcsokban. Utóbbiak esetében a kezdeti, só-indukálta NO felhalmozódás sokkal intenzívebbnek mutatkozott, illetve a letális stressz során tartósabbnak is (15. ábra, C).

A $\mathrm{ONOO}^{-}$képződés csupán a letális $\mathrm{NaCl}$ kezelés hatására emelkedett meg szignifikánsan, ami kifejezettebb volt a $N r$ mutáns esetében (15. ábra, D).

A $\mathrm{NaCl}$ kezelés káros hatásainak meghatározására többek között a gyökércsúcs sejtjeinek életképességét detektáló FDA festését választottuk. $250 \mathrm{mM} \mathrm{NaCl}$ jelenlétében, 6 óra elteltével szignifikáns életképesség csökkenést tapasztaltunk mindkét genotípusban (16. ábra). Hasonló változást figyeltünk meg a $N r$ gyökércsúcsok esetében is szubletális stressz során, ellentétben a VT növényekkel. Ez azt sugallja, hogy a $N r$ mutánsok gyökércsúcsi sejtjeinek sóérzékenysége jóval magasabb, így a károsodás is sokkal kifejezettebbé vált a 24. órára.

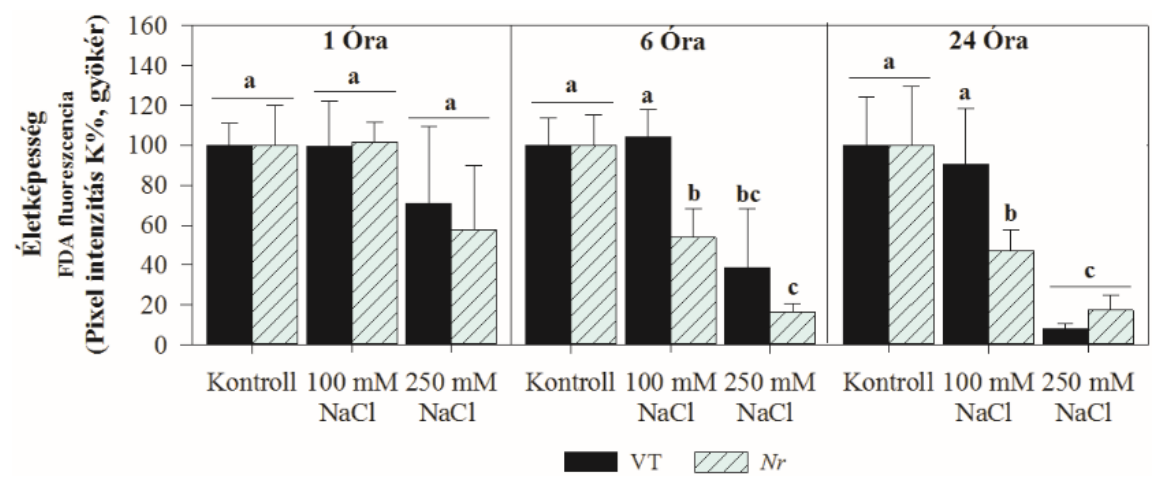

16. ábra $\mathrm{Az}$ FDA fluoreszcencia (életképesség) VT (fekete oszlopok) és $N r$ mutáns (ferdecsíkos, halványkék oszlopok) paradicsomnövények járulékos gyökereinek apikális régiójában a $100 \mathrm{mM}$ ill. $250 \mathrm{mM} \mathrm{NaCl}$ kezelés 1.6 . és 24 . óráját követően, a kontroll értékek \%-ában ábrázolva. Átlag $+\mathrm{SD}, \mathrm{n}=6$. A különböző betüvel jelölt értékek szignifikáns különbségeket mutatnak a kezelések között, az adott időponton belül $\mathrm{P} \leq 0,05$ szinten (Duncan teszt).
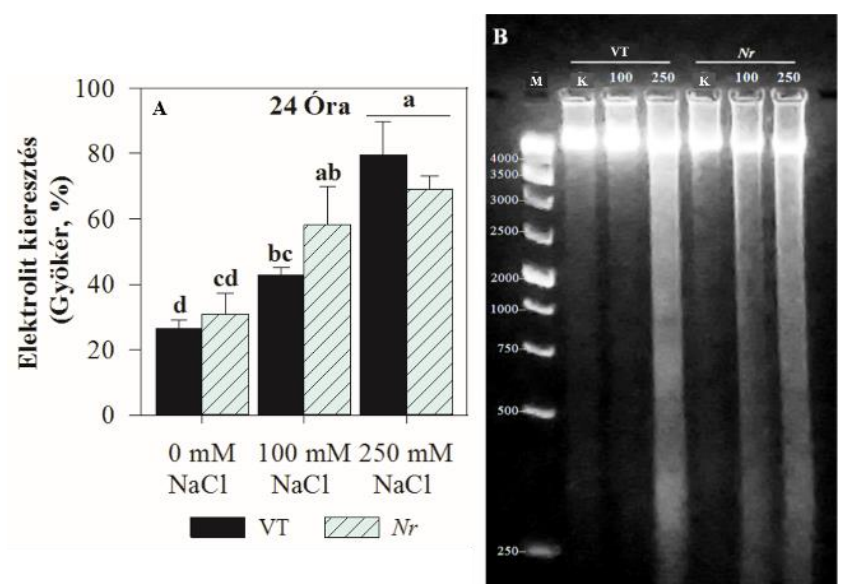

17. ábra $\mathrm{Az}$ elektrolit-kieresztésben (A) és a DNS-fragmentációban (B) bekövetkező változások VT és $N r$ mutáns paradicsomnövények járulékos gyökereiben 24 órás 100 ill. $250 \mathrm{mM}$-os NaCl kezelést követően. M: DNS marker. Átlag + SD, n = 6. A különböző betűvel jelölt értékek szignifikáns különbségeket mutatnak a kezelések között (A) $\mathrm{P} \leq 0,05$ szinten (Duncan teszt). 
A szövetek elektrolit kieresztése szintén tükrözi a stressz által okozott membránkárosodást. A gyökércsúcsi sejtek életképességében bekövetkező sóstressz okozta változásokat a teljes gyökérzet elektrolit-kieresztésének vizsgálata is megerősítette (17. ábra, A). Az elektrolit-kieresztés mértéke $80 \%$-os volt mindkét genotípus esetében az erős sóstressz 24. órájában, míg 55\%-os a $\mathrm{Nr}$ gyökerekben $100 \mathrm{mM} \mathrm{NaCl}$ kezelés hatására.

A sejtek életképességének csökkenésével párhuzamosan egyes sejtek elhalnak. A kialakuló programozott sejthalál mértékét a DNS degradáció is tükrözi. A DNS-fragmentáció mindkét genotípusban megfigyelhető volt a 250 mM-os NaCl kezelés hatására, ugyanúgy, mint a szubletális sóstresszt elszenvedő $N r$ gyökerek esetében (17. ábra, B).

Az ion-homeosztázis fenntartása, különösen az optimális $\mathrm{K}^{+} / \mathrm{Na}^{+}$arány alapvető a sejtek túléléséhez a sóstressz során, mivel az ionegyensúlyban bekövetkező irreverzibilis változások képesek aktiválni a PCD-t. A 24 órán át jelen levő, letális $\mathrm{NaCl}$ koncentráció mindkét genotípusban csökkent $\mathrm{K}^{+}$tartalmat eredményezett, illetve már a szubletális sóstressz is hasonló változást okozott a $N r$ gyökerekben. Emellett, a sókezelések hatására szignifikáns $\mathrm{Na}^{+}$ akkumuláció volt mérhető mindkét genotípusban (6. táblázat). $\mathrm{A} \mathrm{K}^{+} / \mathrm{Na}^{+}$arány mindkét sókoncentráció esetében a $N r$ gyökerekben csökkent jelentősebb mértékben az alacsony $\mathrm{K}^{+}$ tartalom miatt, míg a VT gyökerekben csak $250 \mathrm{mM} \mathrm{NaCl}$ koncentrációnál volt megfigyelhető.

6. táblázat $\mathrm{A} \mathrm{K}^{+}$és $\mathrm{Na}^{+}$tartalmakban (mg száraz tömeg ${ }^{-1} \mathrm{~g}^{-1}$ ), valamint a $\mathrm{K}^{+} / \mathrm{Na}^{+}$arányban bekövetkező változások VT és $\mathrm{Nr}$ mutáns paradicsomnövények járulékos gyökereiben 24 órás 100 ill. $250 \mathrm{mM}$-os $\mathrm{NaCl}$ kezelést követően

\begin{tabular}{|c|c|c|c|c|c|c|}
\hline & \multicolumn{2}{|l|}{ Kontroll } & \multicolumn{2}{|l|}{$100 \mathrm{mM} \mathrm{NaCl}$} & \multicolumn{2}{|l|}{$250 \mathrm{mM} \mathrm{NaCl}$} \\
\hline & VT & $\mathrm{Nr}$ & VT & $\mathrm{Nr}$ & VT & $\mathrm{Nr}$ \\
\hline $\mathrm{K}^{+}$ & $23,8 \pm 2,5^{b}$ & $17,6 \pm 3,75^{\mathrm{b}}$ & $39,44 \pm 7,33^{\mathrm{a}}$ & $12,43 \pm 3,13^{\mathrm{c}}$ & $9,66 \pm 1,29^{c}$ & $6,03 \pm 0,7^{\mathrm{c}}$ \\
\hline$\overline{\mathrm{Na}^{+}}$ & $14,16 \pm 0,14^{\mathrm{d}}$ & $12,8 \pm 1,75^{\mathrm{d}}$ & $25,33 \pm 1,73^{\mathrm{b}}$ & $20,62 \pm 0,3^{\mathrm{c}}$ & $27,93 \pm 0,94^{a}$ & $26,16 \pm 1,36^{\mathrm{ab}}$ \\
\hline $\mathrm{K}^{+} / \mathrm{Na}^{+}$ & $1,680,17^{\mathrm{a}}$ & $1,36 \pm 0,12^{\mathrm{b}}$ & $1,55 \pm 0,18^{\mathrm{ab}}$ & $0,6 \pm 0,16^{\mathrm{c}}$ & $0,35 \pm 0,06^{\mathrm{d}}$ & $0,23 \pm 0,01^{\mathrm{d}}$ \\
\hline
\end{tabular}

Átlag \pm SD, $n=6$. A különböző betűvel jelölt értékek szignifikáns eltéréseket mutatnak a kezelések között $\mathrm{P} \leq 0,05$ szinten (Duncan teszt).

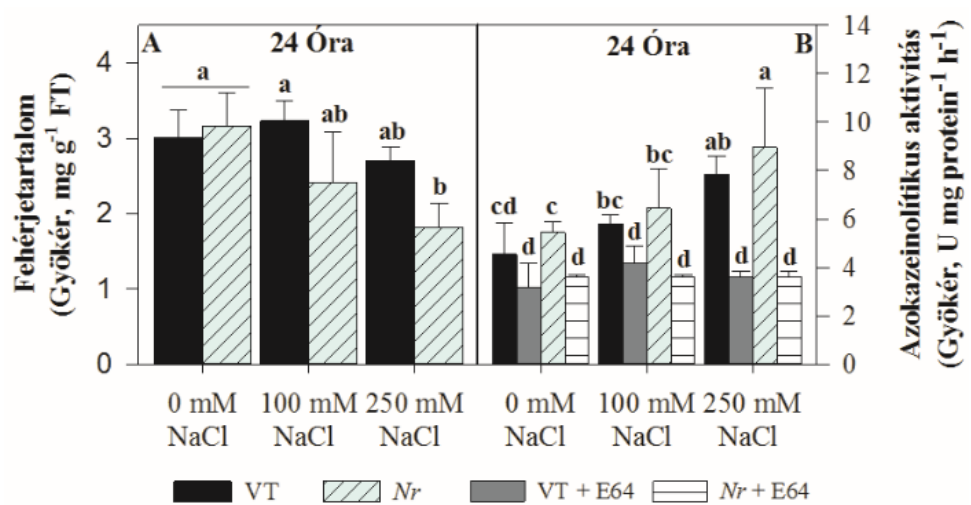

18. ábra A fehérje tartalomban (A) és az össz-proteolitikus aktivitásban (B) bekövetkező változások VT (fekete oszlopok) és $N r$ mutáns (ferdecsíkos, halványkék oszlopok) paradicsomnövények mellékgyökereiben 24 órás $100 \mathrm{mM}$ ill. $250 \mathrm{mM} \mathrm{NaCl}$ kezelést követően, a specifikus cisztein proteáz gátlószer, E64 hiányában, vagy jelenlétében VT (sötétszürke oszlopok) és $N r$ mutáns (fehér, csíkos oszlopok) gyökereiben. Átlag $+\mathrm{SD}, \mathrm{n}=6$. A különböző betủvel jelölt értékek szignifikáns különbségeket mutatnak a kezelések között $\mathrm{P} \leq 0,05$ szinten (Duncan teszt).

A stressz egyik velejárója lehet a fehérjék degradációjának fokozódása, amit specifikus proteázok katalizálnak. A sejthalállal kapcsolatosan különösen fontos lehet a cisztein proteázok 
aktiválódása. A $250 \mathrm{mM} \mathrm{NaCl}$ jelenléte redukált protein tartalmakat okozott a VT és $\mathrm{Nr}$ gyökerekben egyaránt (18. ábra, A), amivel párhuzamosan a proteolitikus aktivitás is növekedett (18. ábra, B), mindez megfigyelhető volt a $N r$ növények esetében is szubletális sóstresszt követően. A specifikus cisztein proteáz gátló, az E-64 csökkentette a teljes proteáz aktivitást a gyökerekben, mely után láthatóvá vált, hogy a stresszhatás erősödésével az összproteolitikus aktivitás egyre nagyobb hányadában vettek részt a cisztein proteázok.

\subsection{A paradicsomnövények etilén státuszától függő változások tolerálható és letális sóstressz során}

\subsubsection{A só-indukált etilén produkció, a növekedés, a vízháztartás és a klorofill- valamint a $\mathrm{Na}^{+}$és $\mathrm{K}^{+}$tartalmak változása különböző ET státuszú növényekben}

A növények ET státuszának módosítására a VT növényeket exogén ACC-vel gyökéren keresztül (elő)kezeltük. Az ET jelátvitel hiányának sóstressz akklimatizációra gyakorolt hatását pedig az ET receptor mutáns $\mathrm{Nr} / \mathrm{Nr}$ növényekben vizsgáltuk.

A $10 \mu \mathrm{M}$ ACC hozzáadását követő 2. órában - a kísérlet 0 időpontja az ACC kezelés 1. órájának leteltétől számítva - az ACC-kezelt VT gyökérben több mint kétszer magasabb ET emissziót detektáltunk, mint a kezeletlen VT növények esetében. Az ET felszabadulás mértékének maximuma a 6 órás mintavételkor volt megfigyelhető, azonban 24 óra után sem esett vissza a kezeletlen VT értékre (19. ábra, B). Só hiányában a $N r$ gyökerek ET produkciója nem különbözött a VT növényekétől.

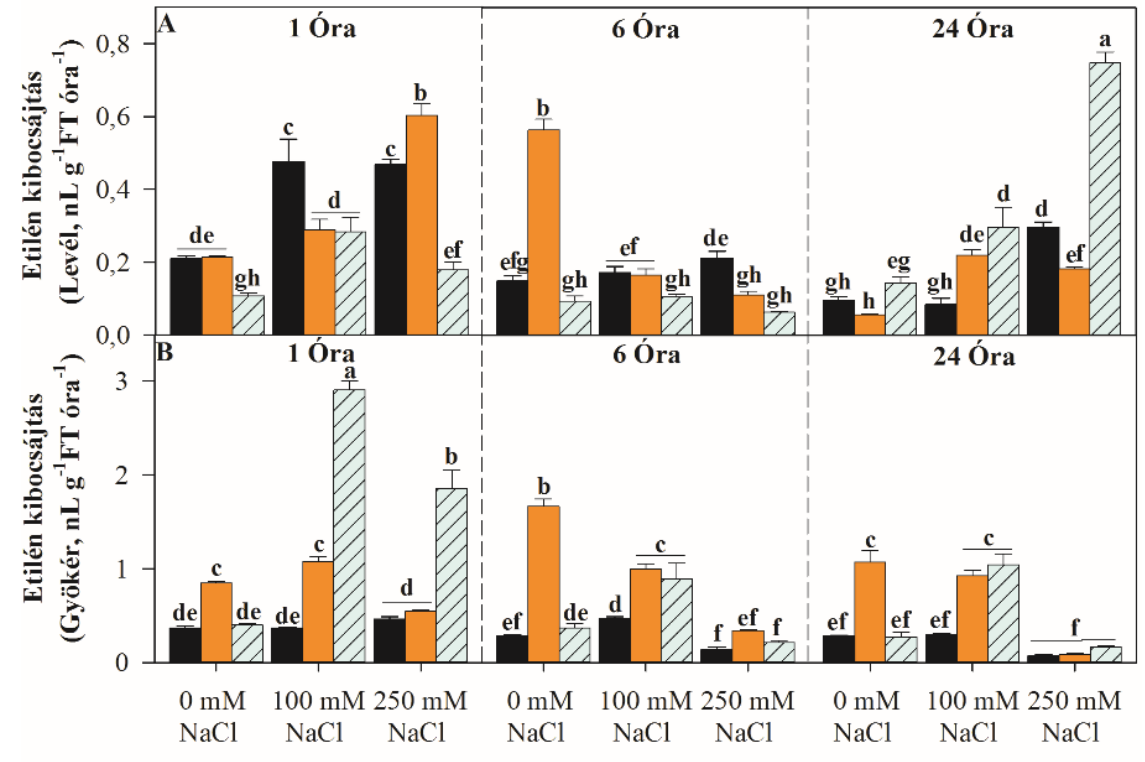

19. ábra A kifejlett, nem öregedő levelek (A) és a gyökerek (B) ET kibocsájtása, VT (fekete oszlopok) és $N r$ mutáns (ferdecsíkos, halványkék oszlopok) (0 $\mu \mathrm{M}$ ACC), valamint $10 \mu \mathrm{M}$ ACC-vel kezelt VT (narancssárga oszlopok) paradicsomnövényekben 1, 6, ill. 24 órás 100 ill. $250 \mathrm{mM}$-os $\mathrm{NaCl}$ expozíciót követően. A kísérlet kezdő időpontja a VT növények ACC kezelése 1. órájától számítva. Átlag $+\mathrm{SE}, \mathrm{n}=4$. „FT” = friss tömeg. A különböző betűvel jelölt értékek szignifikáns különbségeket mutatnak a kezelések és az eltérő időpontok között $\mathrm{P} \leq 0,05$ szinten, (SNK teszt). 
A 100 mM-os ill. $250 \mathrm{mM}$-os $\mathrm{NaCl}$ koncentrációk hozzáadását követően a VT gyökerekben csupán 6 óra elteltével, a tolerálható stressz jelenlétében találtunk szignifikáns ET emisszió növekedést, míg a letális stressz a 24. órára szignifikáns visszaesést okozott a paraméter értékeiben (19. ábra, B). Az exogén ACC jelenléte a szubletális sóstressz során tartósan, szignifikánsan növelte a gyökér ET kibocsájtását a megfelelő sókezelt VT-hez képest, azonban letális sóstressz során csupán a 6. órában okozott emelkedést. A $N r$ mutánsok gyökerei szinte azonnali, drasztikusan megemelkedett ET emisszióval válaszoltak a $\mathrm{NaCl}$ megjelenésére a tápoldatban, mely szubletális stressz során a 6. és 24 . órában alacsonyabb, de a VT értékénél szignifikánsan magasabb szintre állt be, az extra ACC-vel kezelt VT gyökerekhez hasonlóan. Érdekes módon, a gyökérzóna megnövelt ACC tartalma csupán a 6. órában váltott ki szignifikáns - több mint háromszor magasabb - ET emissziót a levélben, jóllehet a VT kontroll növények ET produkciója kissé magasabb volt az 1 órás mintavételi időpontban, mint a későbbi időpontokban (19. ábra, A). A gyökérrel ellentétben, a kezeletlen $N r$ levelek ET emissziója szignifikánsan alacsonyabb volt, mint a VT növényeké az 1 órás mintavételkor.

A VT levelek már 1 óra múltán is jelentős ET produkcióval válaszoltak a sókezelésekre, ez 100 mM NaCl-nál az első órában mutatott maximumot, majd az idő előre haladtával kontroll értékre állt be (19. ábra, A). A $250 \mathrm{mM} \mathrm{NaCl}$ hatására a VT levél szintén megemelkedett ET produkcióval válaszolt, mely az 1 . és a 24 . órában mutatott maximumot és bizonyult szignifikánsnak. A levélben a gyökérével ellentétes tendenciákat lehetett felfedezni a $10 \mu \mathrm{M}$ ACC jelenlétében történő 100 mM-os $\mathrm{NaCl}$ kezelés során, ahol az első órában az ACC csökkentette a sóstressz indukált ET produkciót. A letális sókoncentráció exogén ACC jelenlétében még tovább növelte a levelek ET-termelését az 1. óra elteltével, míg 6 és 24 óra után, váratlan módon szignifikánsan gátolta azt a megfelelő sókezelést kapott VT levelekhez képest. A $N r$ levél esetében a szubletális, illetve a letális sókezelés 24. órája után találtunk szignifikáns emelkedést az ET produkcióban.

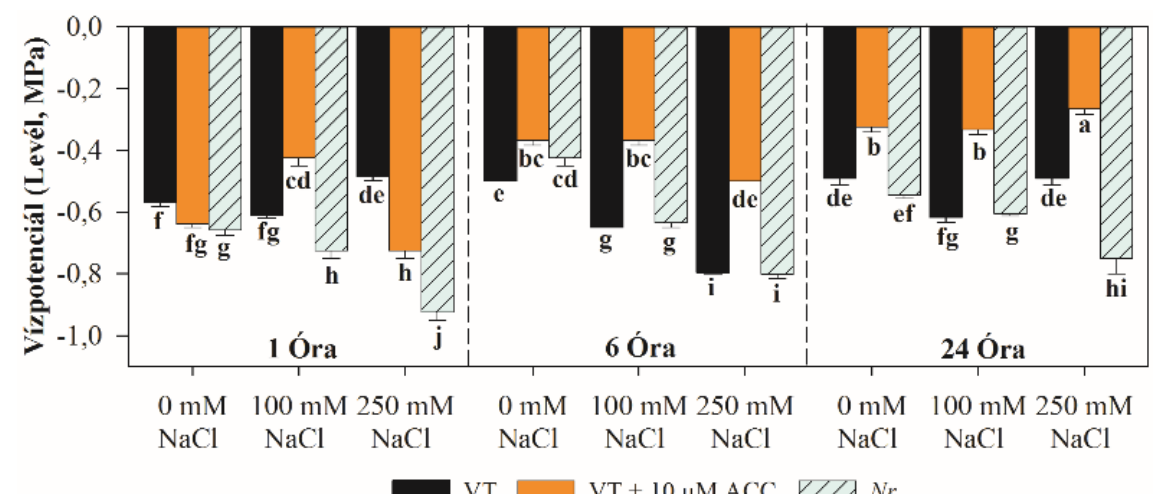

20. ábra A vízpotenciál VT (fekete oszlopok) és $N r$ mutáns (ferdecsíkos, halványkék oszlopok) ( $0 \mu \mathrm{M}$ ACC), valamint $10 \mu \mathrm{M}$ ACC vel kezelt VT (narancssárga oszlopok) paradicsomnövények leveleiben 1, 6, ill. 24 órás $100 \mathrm{mM}$ ill. $250 \mathrm{mM} \mathrm{NaCl}$ expozíciót követően. A kísérlet kezdő időpontja a VT növények ACC kezelése 1. órájától számítva. Átlag $+S E, n=4$. A különbözö betűvel jelölt értékek szignifikáns különbségeket mutatnak a kezelések és az eltérő időpontok között P $\leq 0,05$ szinten, (SNK teszt). 
A $N r$ mutánsok leveleinek $\psi_{\mathrm{w}}$ értékei kezeletlen állapotban is mutattak apróbb, időfüggő eltéréseket a VT növényekéhez képest (20. ábra). A $100 \mathrm{mM} \mathrm{NaCl}$ jelenléte a $\mathrm{Nr}$ mutánsok vízpotenciálját tartósan csökkentette, mely a VT levelek esetében időben eltolva jelentkezett.

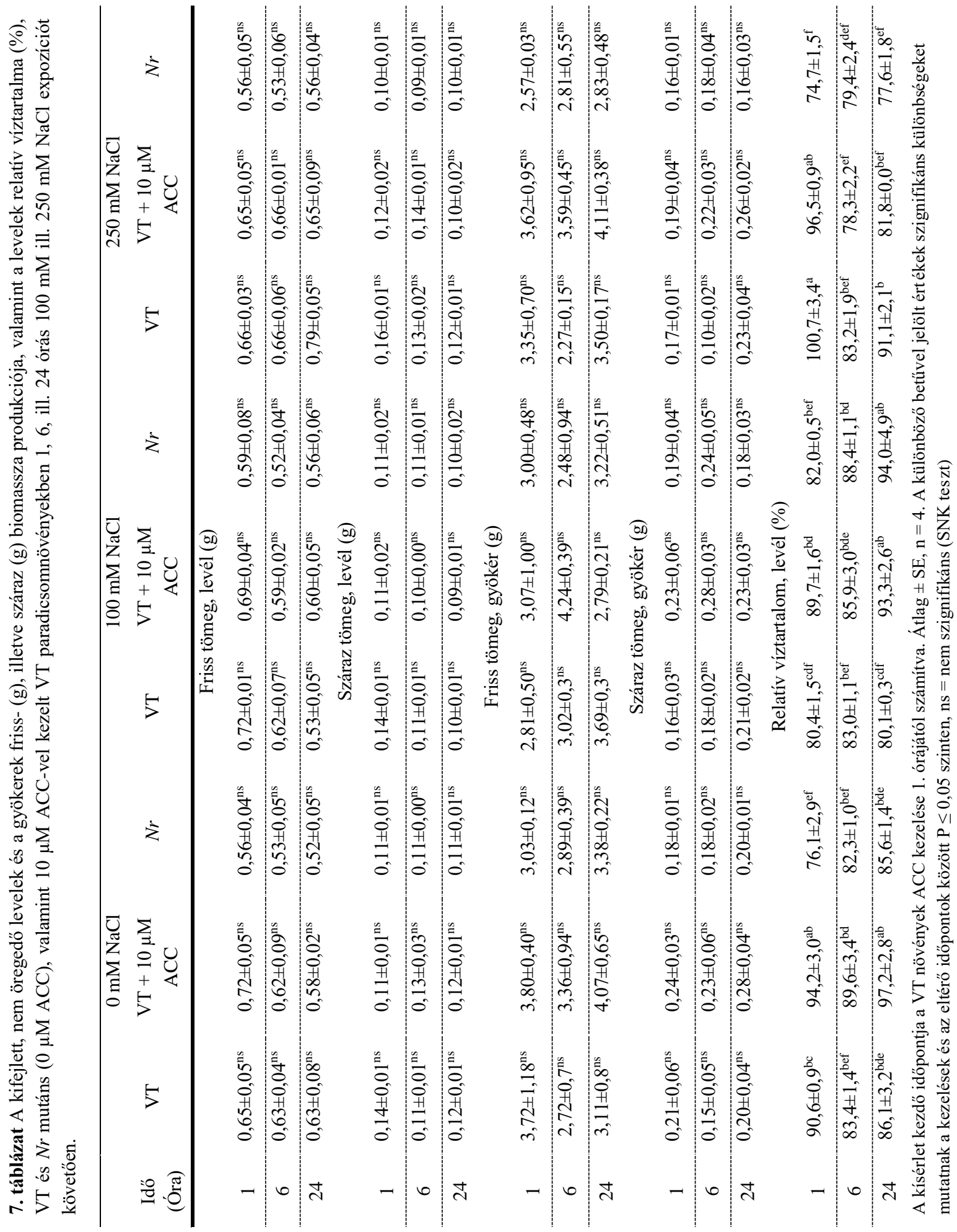

$250 \mathrm{mM} \mathrm{NaCl}$ eleinte növelte, majd a 6 óra elteltével kb. 60\%-kal csökkentette, később kontroll szintre állította a VT levelek vízpotenciálját, míg a $\mathrm{Nr}$ mutánsok végig jóval alacsonyabb $\psi_{\mathrm{w}}$ értékekkel rendelkeztek (20. ábra). Az ACC kezelés a letális sóstressz első 
óráján kívül- ahol erős csökkenést okozott - szignifikáns emelkedést indukált a VT levelek vízpotenciáljában sóstressz során, illetve az 1 órás mintavételt kivéve, $\mathrm{NaCl}$ hiányában is.

Nem tapasztaltunk jelentős különbségeket a levelek, illetve a gyökerek friss- és száraz tömegeiben a kísérletek során (7. táblázat). A $N r$ levelek alacsonyabb relatív víztartalommal (RVT) rendelkeztek az 1 órás mintavételi időpontban, mint a VT, illetve ACC-kezelt növények, mely különbség az idő elörehaladtával eltünt (7. táblázat). A $N r$ mutánsokban az ACC-kezelt VT levelekhez hasonló RVT emelkedést tapasztaltunk a szubletális stressz 24. órájában. Érdekes módon, a letális $\mathrm{NaCl}$ koncentráció 1 óra után szignifikáns RVT emelkedést okozott ugyanúgy, ahogy az ACC kezelt növények esetében, ezzel szemben a $\mathrm{Nr}$ mutánsokban szignifikáns csökkenést detektáltunk 24 órát követően.

A VT gyökerek $\mathrm{K}^{+}$tartalma a sókoncentráció növekedésével egyenes arányban csökkent, azonban a $\mathrm{Na}^{+}$akkumulációs kapacitásuk már $100 \mathrm{mM} \mathrm{NaCl}$ jelenlétében telítődött (8. táblázat). A VT gyökerek $\mathrm{K}^{+} / \mathrm{Na}^{+}$aránya a $\mathrm{K}^{+}$tartalomhoz hasonló tendenciában csökkent a sókezelések hatására. A megfigyelt változásokat a kezeletlen kontroll és a $100 \mathrm{mM} \mathrm{NaCl}$ esetén nem befolyásolta az exogén ACC kezelés, letális sókoncentrációnál az iontartalmak és a $\mathrm{K}^{+} / \mathrm{Na}^{+}$is csökkenni kezdett, bár nem szignifikánsan a VT-hez képest ACC elökezelés után.

8. táblázat A kálium $\left(\mathrm{K}^{+}\right)$és nátrium $\left(\mathrm{Na}^{+}\right)$tartalom, valamint a $\mathrm{K}^{+} / \mathrm{Na}^{+}$arány $\left(\mathrm{mg} \mathrm{g}^{-1}\right.$ száraz tömeg), VT és $10 \mu \mathrm{M}$ ACC-vel kezelt VT paradicsomnövények gyökereiben 24 órás 100 ill. $250 \mathrm{mM}$-os $\mathrm{NaCl}$ expozíciót követően.

\begin{tabular}{|c|c|c|c|c|c|c|}
\hline & \multicolumn{2}{|c|}{ Kontroll } & \multicolumn{2}{|c|}{$100 \mathrm{mM} \mathrm{NaCl}$} & \multicolumn{2}{|c|}{$250 \mathrm{mM} \mathrm{NaCl}$} \\
\hline & VT & $\begin{array}{l}\mathrm{VT}+10 \mu \mathrm{M} \\
\mathrm{ACC}\end{array}$ & VT & $\begin{array}{l}\mathrm{VT}+10 \mu \mathrm{M} \\
\mathrm{ACC}\end{array}$ & VT & $\begin{array}{l}\mathrm{VT}+10 \mu \mathrm{M} \\
\mathrm{ACC}\end{array}$ \\
\hline $\mathrm{K}^{+}$ & $\begin{array}{l}32,02 \\
\pm 1,2^{\mathrm{a}}\end{array}$ & $\begin{array}{l}34,41 \\
\pm 2,1^{\text {a }}\end{array}$ & $\begin{array}{l}19,46 \\
\pm 1,5^{\mathrm{b}}\end{array}$ & $\begin{array}{l}21,45 \\
\pm 2,0^{b}\end{array}$ & $\begin{array}{l}5,79 \\
\pm 3,4^{\mathrm{c}}\end{array}$ & $\begin{array}{l}2,76 \\
\pm 1,4^{\mathrm{c}}\end{array}$ \\
\hline $\mathrm{Na}^{+}$ & $\begin{array}{l}7,50 \\
\pm 1,1^{\mathrm{c}}\end{array}$ & $\begin{array}{l}8,99 \\
\pm 0,2^{\mathrm{c}}\end{array}$ & $\begin{array}{l}18,97 \\
\pm 1,3^{\mathrm{ab}}\end{array}$ & $\begin{array}{l}15,63 \\
\pm 1,1^{\mathrm{b}}\end{array}$ & $\begin{array}{l}22,11 \\
\pm 4,4^{\text {a }}\end{array}$ & $\begin{array}{l}17,49 \\
\pm 1,7^{\mathrm{ab}}\end{array}$ \\
\hline $\mathrm{K}^{+} / \mathrm{Na}^{+}$ & $\begin{array}{l}3,72 \\
\pm 0,1^{\mathrm{a}}\end{array}$ & $\begin{array}{l}3,84 \\
\pm 0,3^{\mathrm{a}}\end{array}$ & $\begin{array}{l}1,03 \\
\pm 0,1^{\mathrm{b}}\end{array}$ & $\begin{array}{l}1,41 \\
\pm 0,2^{b}\end{array}$ & $\begin{array}{l}0,28 \\
\pm 0,2^{\mathrm{c}}\end{array}$ & $\begin{array}{l}0,15 \\
\pm 0,1^{\mathrm{c}}\end{array}$ \\
\hline
\end{tabular}

Átlag $\pm \mathrm{SE}, \mathrm{n}=3$. A különböző betűvel jelölt értékek szignifikáns eltéréseket mutatnak a kezelések között $\mathrm{P} \leq 0,05$ szinten Duncan teszt).

9. táblázat $\mathrm{A}$ kálium $\left(\mathrm{K}^{+}\right)$és nátrium $\left(\mathrm{Na}^{+}\right)$tartalom, valamint a $\mathrm{K}^{+} / \mathrm{Na}^{+}$arány $\left(\mathrm{mg} \mathrm{g}^{-1}\right.$ száraz tömeg), $\mathrm{VT}$ és $\mathrm{Nr}$ mutáns $(0 \mu \mathrm{M}$ ACC), valamint $10 \mu \mathrm{M}$ ACC-vel kezelt VT paradicsomnövények leveleiben 24 órás 100 ill. 250 mM-os NaCl expozíciót követően.

\begin{tabular}{|c|c|c|c|c|c|c|c|c|c|}
\hline & \multicolumn{3}{|c|}{$0 \mathrm{mM} \mathrm{NaCl}$} & \multicolumn{3}{|c|}{$100 \mathrm{mM} \mathrm{NaCl}$} & \multicolumn{3}{|c|}{$250 \mathrm{mM} \mathrm{NaCl}$} \\
\hline & VT & $\begin{array}{c}\mathrm{VT}+10 \mu \mathrm{M} \\
\mathrm{ACC}\end{array}$ & $\mathrm{Nr}$ & VT & $\begin{array}{c}\mathrm{VT}+10 \mu \mathrm{M} \\
\mathrm{ACC}\end{array}$ & $\mathrm{Nr}$ & VT & $\begin{array}{c}\mathrm{VT}+10 \mu \mathrm{M} \\
\mathrm{ACC}\end{array}$ & $\mathrm{Nr}$ \\
\hline \multirow[t]{2}{*}{$\mathrm{K}^{+}$} & 21,60 & 21,27 & 21,73 & 19,00 & 19,38 & 13,98 & 20,97 & 24,09 & 21,08 \\
\hline & $\pm 1,5^{\mathrm{a}}$ & $\pm 0,8^{\mathrm{a}}$ & $\pm 2,3^{\mathrm{a}}$ & $\pm 0,1^{\mathrm{a}}$ & $\pm 2,5^{\mathrm{a}}$ & $\pm 1,7^{\mathrm{b}}$ & $\pm 1,9^{\mathrm{a}}$ & $\pm 3,4^{\mathrm{a}}$ & $\pm 1,8^{\mathrm{a}}$ \\
\hline \multirow[t]{2}{*}{$\mathrm{Na}^{+}$} & 0,91 & 1,26 & 0,90 & 1,59 & 2,87 & 3,50 & 24,90 & 29,56 & 32,59 \\
\hline & $\pm 0,2^{\mathrm{d}}$ & $\pm 0,1^{\mathrm{d}}$ & $\pm 0,2^{\mathrm{d}}$ & $\pm 0,4^{\mathrm{d}}$ & $\pm 0,5^{\mathrm{c}}$ & $\pm 0,4^{\mathrm{c}}$ & $\pm 0,2^{\mathrm{b}}$ & $\pm 5,0^{\mathrm{a}}$ & $\pm 0,1^{\mathrm{a}}$ \\
\hline \multirow[t]{2}{*}{$\mathrm{K}^{+} / \mathrm{Na}^{+}$} & 25,39 & 17,40 & 21,73 & 13,47 & 7,62 & 4,17 & 0,84 & 0,87 & 0,65 \\
\hline & $\pm 5,2^{\mathrm{a}}$ & $\pm 1,9^{\mathrm{ab}}$ & $\pm 3,4^{\mathrm{ab}}$ & $\pm 3,0^{\mathrm{b}}$ & $\pm 2,4^{\mathrm{b}}$ & $\pm 0,9^{c}$ & $\pm 0,1^{\mathrm{c}}$ & $\pm 0,3^{c}$ & $\pm 0,1^{\mathrm{c}}$ \\
\hline
\end{tabular}

A kísérlet kezdő időpontja a VT növények ACC kezelése 1. órájától számítva. Átlag $+\mathrm{SE}, \mathrm{n}=3$. A különböző betűvel jelölt értékek szignifikáns különbségeket mutatnak a kezelések között $\mathrm{P} \leq 0,05$ szinten (Duncan teszt).

A sókezelések nem voltak szignifikáns hatással a levelek $\mathrm{K}^{+}$-tartalmára, sem a VT, sem az exogén ACC kezelt VT növényekben, ez ugyanakkor csökkent a $\mathrm{Nr}$ mutánsokban a 
szubletális sóstressz 24. óráját követően (9. táblázat). Az ACC kezelés és a $N r$ mutáció is tovább fokozta a só-indukálta $\mathrm{Na}^{+}$akkumulációt a levelekben, különösen a letális sókoncentráció esetében (9. táblázat). A 24 órás, 100 mM-os NaCl kezelés okozta enyhe csökkenés a VT levelek $\mathrm{K}^{+}$tartalmában, valamint a $\mathrm{Na}^{+}$tartalmuk enyhe növekedése kis mértékben, de szignifikánsan csökkentette a $\mathrm{K}^{+} / \mathrm{Na}^{+}$arányt, mely a $N r$ mutáns kifejezettebb volt. A $250 \mathrm{mM}$ os $\mathrm{NaCl}$ drasztikusan csökkentette az összes csoport $\mathrm{K}^{+} / \mathrm{Na}^{+}$arányát.

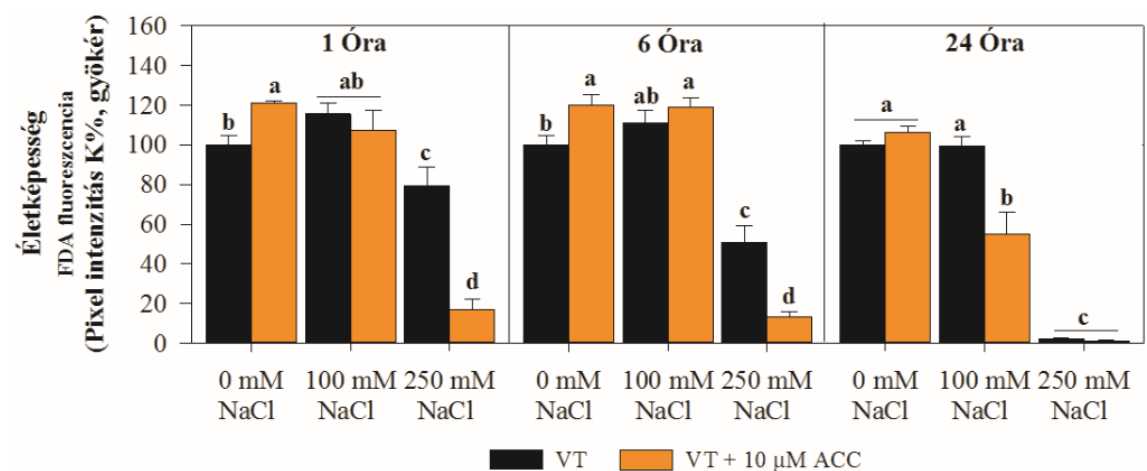

21. ábra A sejt-életképességének változása VT $(0 \mu \mathrm{M}$ ACC, fekete oszlopok), valamint $10 \mu \mathrm{M}$ ACC-vel kezelt VT (narancssárga oszlopok) paradicsom járulékos gyökércsúcsokban, a 100 ill. $250 \mathrm{mM}$-os $\mathrm{NaCl}$ hozzáadását követő 1, 6, ill. 24 óra elteltével. A mért pixelintenzitás értékek az adott időpont kezeletlen, VT gyökér értékeire normálva. A kísérlet kezdő időpontja a VT növények ACC kezelése 1. órájának leteltétől számítva. Átlag $+\mathrm{SE}, \mathrm{n}=4$. A különböző betűvel jelölt értékek szignifikáns különbségeket mu tatnak $\mathrm{P}$ $\leq 0,05$ szinten (Duncan teszt).

Érdekes módon, az exogén ACC kezelés önmagában, szignifikánsan fokozta a gyökércsúcsi sejtek életképességét az egy és hatórás mintavételi időpontokban. Bár a szubletális sókezelés nem okozott életképesség romlást a VT gyökércsúcsokban, az exogén ACC kezeléssel kombinálva mégis tapasztalható szignifikáns csökkenés a paraméterben 24 óra elteltével (21. ábra). Ezzel szemben, az ACC kezelés $250 \mathrm{mM} \mathrm{NaCl}$ jelenlétében tovább csökkentette a gyökércsúcsok életképességét, már 1 órát követően.

10. táblázat A klorofill $a$ és $b(\mathrm{Kl} a, \mathrm{Kl} b)$, illetve karotinoid (Kar) tartalom ( $\mathrm{mg} \mathrm{g}^{-1}$ friss tömeg), VT és $N r$ mutáns $(0 \mu \mathrm{M}$ $\mathrm{ACC}$ ), valamint $10 \mu \mathrm{M}$ ACC-vel kezelt VT paradicsomnövények leveleiben 24 órás 100 ill. $250 \mathrm{mM}$-os $\mathrm{NaCl}$ expozíciót követően.

\begin{tabular}{|c|c|c|c|c|c|c|c|c|c|}
\hline & \multicolumn{3}{|c|}{$0 \mathrm{mM} \mathrm{NaCl}$} & \multicolumn{3}{|c|}{$100 \mathrm{mM} \mathrm{NaCl}$} & \multicolumn{3}{|c|}{$250 \mathrm{mM} \mathrm{NaCl}$} \\
\hline & VT & $\begin{array}{c}\mathrm{VT}+10 \mu \mathrm{M} \\
\mathrm{ACC}\end{array}$ & $\mathrm{Nr}$ & VT & $\begin{array}{c}\mathrm{VT}+10 \mu \mathrm{M} \\
\mathrm{ACC}\end{array}$ & $\mathrm{Nr}$ & VT & $\begin{array}{c}\mathrm{VT}+10 \mu \mathrm{M} \\
\mathrm{ACC}\end{array}$ & $\mathrm{Nr}$ \\
\hline $\mathrm{Kl} a$ & $\begin{array}{c}1,72 \\
\pm 0,02^{\mathrm{de}}\end{array}$ & $\begin{array}{c}1,82 \\
\pm 0,04^{\text {bcd }}\end{array}$ & $\begin{array}{c}1,91 \\
\pm 0,05^{\mathrm{b}}\end{array}$ & $\begin{array}{c}1,68 \\
\pm 0,03^{\mathrm{de}}\end{array}$ & $\begin{array}{c}2,02 \\
\pm 0,04^{\mathrm{a}}\end{array}$ & $\begin{array}{c}1,84 \\
\pm 0,05^{\mathrm{bc}}\end{array}$ & $\begin{array}{c}1,77 \\
\pm 0,03^{\text {cd }}\end{array}$ & $\begin{array}{c}1,73 \\
\pm 0,02^{\text {de }}\end{array}$ & $\begin{aligned} & 1,65 \\
\pm & 0,01^{\mathrm{e}}\end{aligned}$ \\
\hline $\mathrm{Kl} b$ & $\begin{array}{c}0,58 \\
\pm 0,02^{\mathrm{d}}\end{array}$ & $\begin{array}{c}0,65 \\
\pm 0,04^{\mathrm{d}}\end{array}$ & $\begin{array}{c}1,15 \\
\pm 0,06^{\mathrm{a}}\end{array}$ & $\begin{array}{c}0,61 \\
\pm 0,02^{\mathrm{d}}\end{array}$ & $\begin{array}{c}0,76 \\
\pm 0,02^{c}\end{array}$ & $\begin{array}{c}0,97 \\
\pm 0,03^{\mathrm{b}}\end{array}$ & $\begin{array}{c}0,66 \\
\pm 0,02^{\mathrm{d}}\end{array}$ & $\begin{array}{c}0,59 \\
\pm 0,01^{\mathrm{d}}\end{array}$ & $\begin{array}{c}0,80 \\
\pm 0,03^{\mathrm{c}}\end{array}$ \\
\hline Kar & $\begin{array}{c}0,34 \\
\pm 0,01^{\mathrm{d}}\end{array}$ & $\begin{array}{c}0,37 \\
\pm 0,01^{\mathrm{d}}\end{array}$ & $\begin{array}{c}0,58 \\
\pm 0,03^{\mathrm{a}}\end{array}$ & $\begin{array}{c}0,36 \\
\pm 0,00^{\mathrm{d}}\end{array}$ & $\begin{aligned} & 0,45 \\
\pm & 0,01^{\mathrm{c}}\end{aligned}$ & $\begin{array}{c}0,49 \\
\pm 0,02^{\mathrm{b}}\end{array}$ & $\begin{array}{c}0,35 \\
\pm 0,01^{\mathrm{d}}\end{array}$ & $\begin{array}{c}0,38 \\
\pm 0,01^{\mathrm{d}}\end{array}$ & $\begin{array}{c}0,43 \\
\pm 0,02^{\mathrm{c}}\end{array}$ \\
\hline
\end{tabular}

A kísérlet kezdő időpontja a VT növények ACC kezelése 1. órájától számítva. Átlag \pm SE, $n=5$. A különböző betüvel jelölt értékek szignifikáns különbségeket mutatnak a kezelések között $\mathrm{P} \leq 0,05$ szinten (Duncan teszt).

A 24 órás, $10 \mu \mathrm{M}$-os ACC kezelés $100 \mathrm{mM} \mathrm{NaCl-al} \mathrm{kombinálva} \mathrm{szignifikánsan,} \mathrm{kb}$. 20\%-kal megemelte a VT növények $\mathrm{Kl} a$ tartalmát, letális $\mathrm{NaCl}$ koncentráció jelenlétében ez azonban nem alakult ki (10. táblázat). A kezeletlen $N r$ mutáns növények csaknem 10\%-kal magasabb $\mathrm{Kl} a$, és körülbelül $50 \%$-kal magasabb $\mathrm{Kl} b$ mennyiséggel rendelkeztek. A VT 
levelek $\mathrm{Kl}$ a tartalmára a sókezelés nem volt jelentős befolyással a vizsgált időszakban. A letális sókoncentráció szignifikánsan csökkentette a $\mathrm{Nr}$ levelek $\mathrm{Kl} a$ tartalmát 24 óra alatt, azonban a megfigyelt értékek szubletális stressz során magasabbnak, míg letális stressz során alacsonyabbnak bizonyultak, mint a hasonló kezelésen átesett, VT növények leveleiben.

A gyökerek exogén ACC kezelése, szubletális sóstresszel kombinálva szignifikánsan megemelte a levelek $\mathrm{Kl} b$ tartalmát a 6 órás mintavételi időpontra (10. táblázat). Annak ellenére, hogy a $\mathrm{Nr}$ levelek Kl $b$ koncentrációja só-indukálta csökkenésen ment keresztül, a kísérletek végére még mindig magasabbnak mutatkozott, mint a VT levelek esetében. A karotinoid tartalom változásai követték a $\mathrm{Kl} b$ esetében megfigyelt tendenciákat (10. táblázat).

\subsubsection{A ROF és RNF akkumuláció só-indukált válaszainak időfüggése megemelt ET produkciójú paradicsomnövényekben}

Mivel a $N r$ mutáns gyökerének sóstressz-válaszait az 5.2.1-es fejezetben már tárgyaltuk, az exogén ACC-vel kezelt, megemelt ET produkcióval rendelkező növények adatait az alábbi alfejezetben foglaltuk össze.

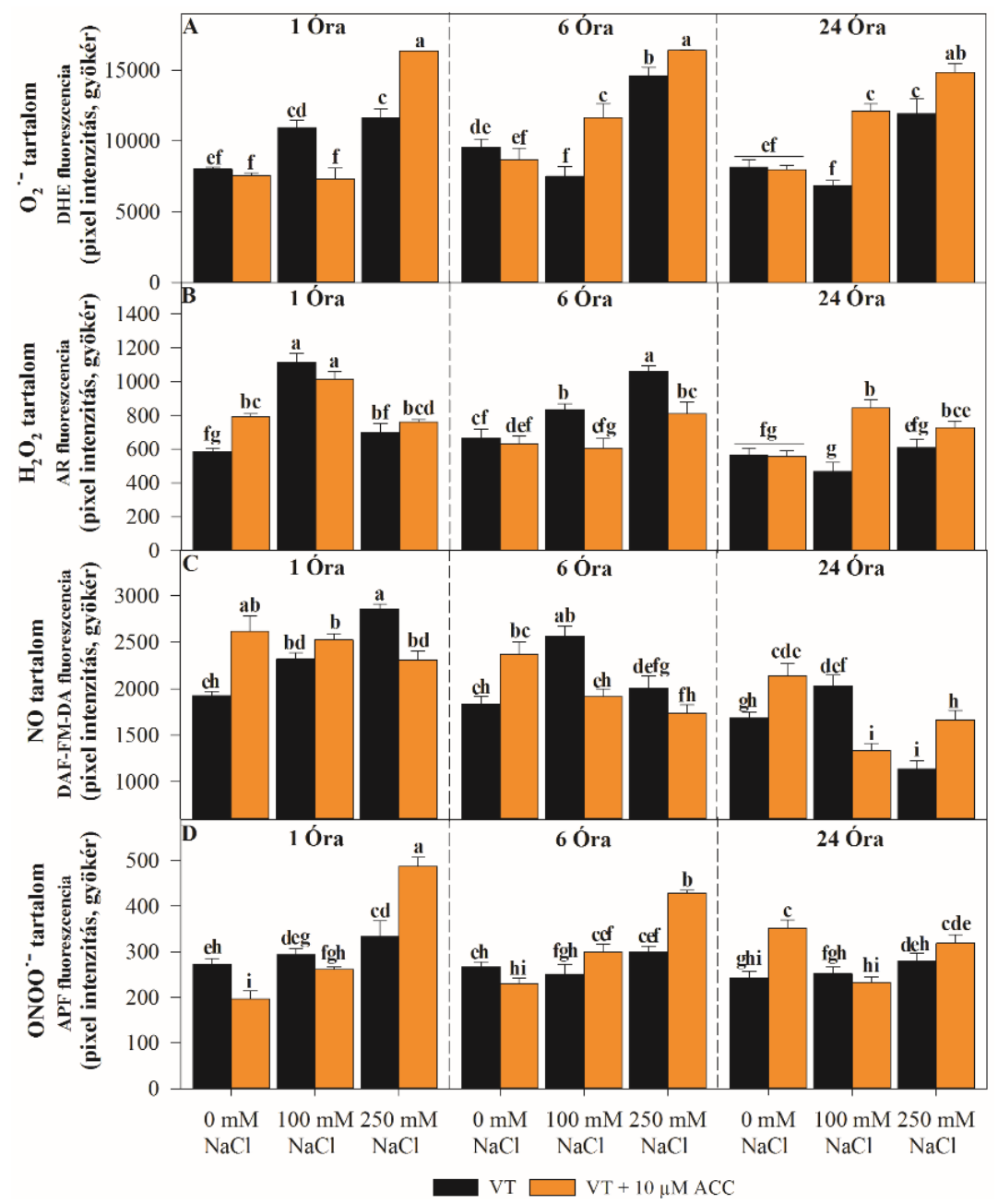

22. ábra $\mathrm{A} \mathrm{O}_{2}{ }^{--}$(A) a $\mathrm{H}_{2} \mathrm{O}_{2}(\mathrm{~B})$, a $\mathrm{NO}(\mathrm{C})$, illetve a $\mathrm{ONOO}^{-}$(D) akkumulációja VT $(0 \mu \mathrm{M}$ ACC, fekete oszlopok), valamint $10 \mu \mathrm{M}$ ACC-vel kezelt VT (narancssárga oszlopok) paradicsom járulékos gyökér csúcsokban, a 100 ill. $250 \mathrm{mM-os} \mathrm{NaCl} \mathrm{hozzáadását} \mathrm{követő}$ 1, 6, ill. 24 óra elteltével. A kísérlet kezdő időpontja a VT növények ACC kezelése 1. órájának leteltétől számítva. Átlag + SE, n = 4. A különböző betüvel jelölt értékek szignifikáns különbségeket mutatnak $\mathrm{P} \leq 0,05$ szinten (Duncan teszt). 
Exogén ACC jelentlétében a letális koncentrációjú $\mathrm{NaCl}$ kezelés már az első órától, míg a szubletális sókoncentráció a 6. órától indukált fokozott $\mathrm{O}_{2}{ }^{*-}$ felhalmozódást a VT járulékos gyökércsúcsokban (22. ábra, A).

A $10 \mu \mathrm{M}$-os ACC kezelés megnövelte a VT gyökércsúcsok $\mathrm{H}_{2} \mathrm{O}_{2}$ tartalmát az 1 órás mintavételi időpontban, ugyanakkor sóstressz során csupán a 6. órában detektáltunk szignifikáns, exogén ACC hatást, mely a só-indukálta $\mathrm{H}_{2} \mathrm{O}_{2}$ akkumuláció mérséklődését jelentette (22. ábra, B). Ezzel szemben, 24 órát követően, az ACC-vel kombinált, 100 mM-os só jelenléte hangsúlyos $\mathrm{H}_{2} \mathrm{O}_{2}$ növekedést indukált, ellentétben a $100 \mathrm{mM}$-os $\mathrm{NaCl}$ kezelést önmagában kapott gyökerekkel.

Bár a $10 \mu \mathrm{M}$-os $\mathrm{ACC} \mathrm{NaCl}$ jelenléte nélkül mindhárom időpontban megemelte a $\mathrm{NO}$ szinteket, a szubletális sókezelés 6. órájától, illetve a $250 \mathrm{mM} \mathrm{NaCl}$ hozzáadását követő 1 óra elteltével, az exogén ACC szignifikánsan csökkentette a NO akkumulációt a gyökércsúcsokban (22. ábra, C), ez azonban a letális sóstressz esetében a 24 órás mintánál megfordult. Míg a kísérlet elején az exogén $\mathrm{ACC}$ enyhítette a természetes $\mathrm{ONOO}^{-}$felhalmozódást a gyökércsúcsokban, addig ugyanezt fokozta a 24. órára. Sóval kombinálva viszont, az ACC a letális koncentráció esetében, az 1. és a 6. órában jelentősen fokozta a $\mathrm{ONOO}^{-}$akkumulációt a csak 250 mM-os $\mathrm{NaCl}$ kezelésben részesült gyökerekhez viszonyítva (22. ábra, D).

A megemelkedett $\mathrm{NaCl}$ koncentráció hatására 1 és 24 óra elteltével a VT levelek intenzív $\mathrm{O}_{2}{ }^{*-}$ akkumulációval válaszoltak, mely a 6. órában csupán a $250 \mathrm{mM}$-os $\mathrm{NaCl}$ esetében volt megfigyelhető. Bár mindkét sókezelés megemelt $\mathrm{O}_{2}{ }^{\bullet}$ szinteket eredményezett rövid távon, 1 óra után a $N r$ növények leveleiben, ez a növekedés a későbbi időpontokban elmaradt, hasonlóan az ACC-vel kezelt VT növényekéhez a 250 mM-os $\mathrm{NaCl}$ jelenlétében (23. ábra, A).

A gyökérzónában jelenlévő extra ACC nem okozott szignifikáns változást a VT levelekben a $\mathrm{H}_{2} \mathrm{O}_{2}$ felhalmozódásban szubletális sóstressz alatt. A $N r$ levelekben viszont a VThoz képest hangsúlyosabb $\mathrm{H}_{2} \mathrm{O}_{2}$ felhalmozódást figyeltünk meg a $100 \mathrm{mM}$-os sókezelés 24 .

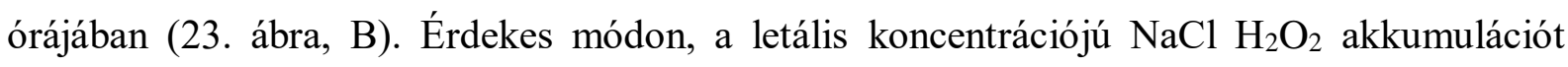
indukáló hatása mind az ACC kezelt, mind a $N r$ mutánsok leveleiben fennmaradt a 24. óráig, bár az ACC alkalmazása esetén kisebb mértékben.

A $100 \mathrm{mM} \mathrm{NaCl}$ enyhén, de szignifikánsan csökkentette a VT levelek NO szintjeit 1 órát követően (23. ábra, C), mely az ACC kezelt és a $N r$ növények esetében elmaradt, sőt a 24. órás mintavételi időponton a két utóbbi csoport esetében drasztikusan megnövekedett NO akkumulációt figyeltünk meg, mely kifejezettebb volt az ACC kezelt növények esetében. A letális sókezelésre a VT levelek gyors, de enyhe NO növekedéssel reagáltak, ami az idő előrehaladtával elhalványult. Ez a jelenség a $N r$ mutánsokban 6 órát követően figyelhető meg. 
A gyökéren keresztüli, exogén ACC kezelés szignifikáns NO felhalmozódást okozott a letális sóstressz 24. óráját követően a levélben.

A $\mathrm{ONOO}^{-}$akkumulációja általában egyenletes volt a mintákban. Az exogén ACC kezelés a só hozzáadását követő 1 órában enyhe, de szignifikáns $\mathrm{ONOO}^{`}$ akkumulációt indukált a VT levelekben a $100 \mathrm{mM}-\mathrm{os} \mathrm{NaCl}$ koncentráció esetében, amely a $\mathrm{Nr}$ levelekben is megmutatkozott (23. ábra, D). 24 óra elteltével viszont az exogén ACC drasztikusan fokozta

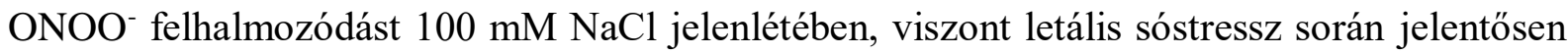
visszafogja azt a VT-hez és a $N r$ mutáció okozta változásokhoz képest.

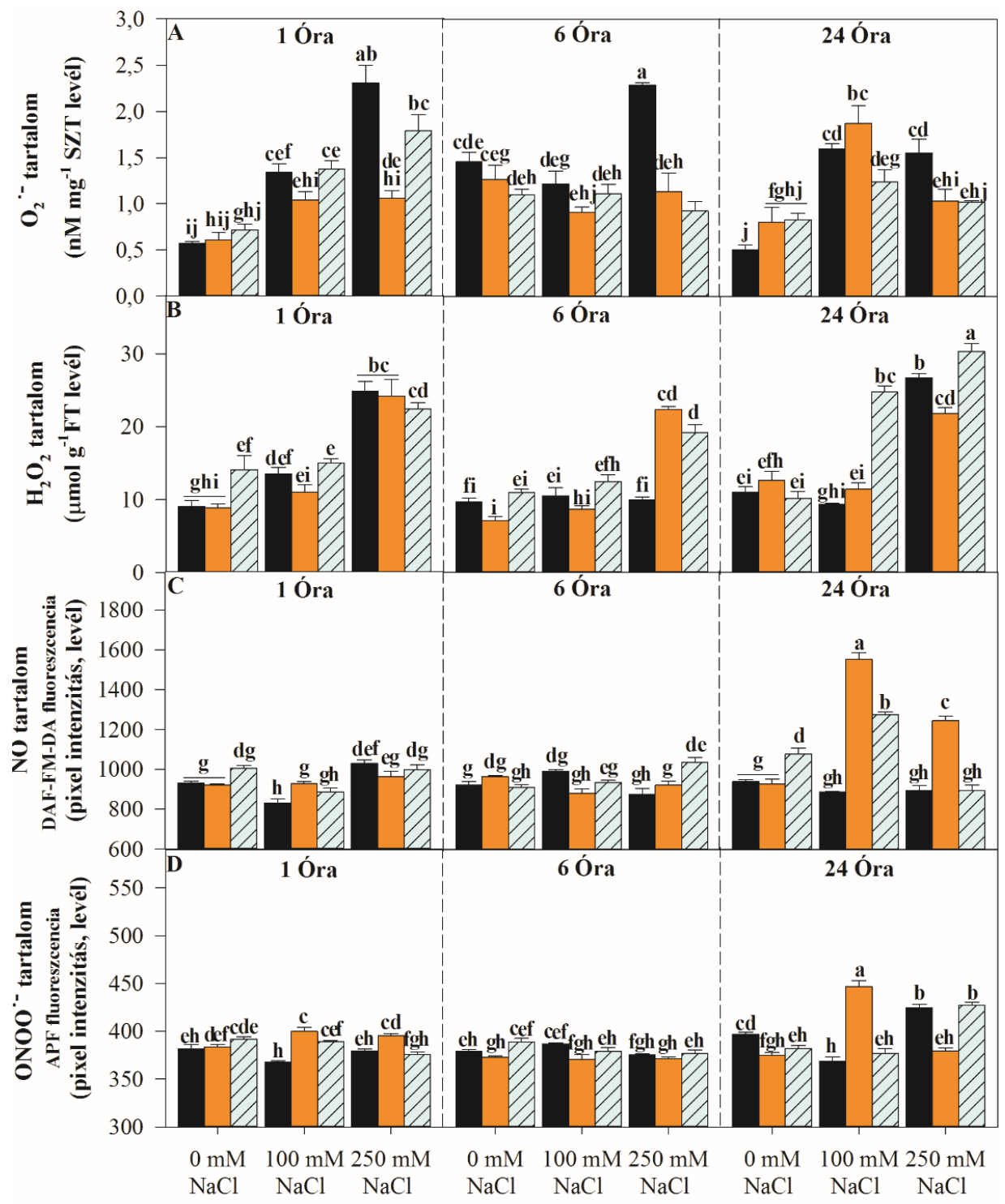

23. ábra $\mathrm{A} \mathrm{O}_{2}{ }^{--}(\mathrm{A})$ a $\mathrm{H}_{2} \mathrm{O}_{2}(\mathrm{~B})$, a $\mathrm{NO}(\mathrm{C})$, illetve a $\mathrm{ONOO}^{-}$(D) akkumulációja VT (fekete oszlopok) és $N r$ mutáns (ferdecsíkos, halványkék oszlopok) (0 $\mu \mathrm{M}$ ACC), valamint $10 \mu \mathrm{M}$ ACC-vel kezelt VT (narancssárga oszlopok) paradicsomnövények leveleiben, a $100 \mathrm{mM}$ ill. $250 \mathrm{mM}$-os $\mathrm{NaCl}$ hozzáadását követő 1, 6, ill. 24 óra elteltével. A kísérlet kezdő időpontja a VT növények ACC kezelése 1. órájának leteltétől számítva. Átlag $+\mathrm{SE}, \mathrm{n}=3(\mathrm{~A}), \mathrm{n}=4(\mathrm{~B}, \mathrm{C}, \mathrm{D})$. A különböző betüvel jelölt értékek szignifikáns különbségeket mutatnak $\mathrm{P} \leq 0,05$ szinten (SNK teszt). 


\subsubsection{A $\mathrm{O}_{2}{ }^{\bullet-}$ és a $\mathrm{H}_{2} \mathrm{O}_{2}$ lebontásában szerepet játszó antioxidáns enzimek só-indukált aktivitásváltozásainak ET- és időfüggése}

Bizonyos enzimek aktivitása esetén a kezeletlen, VT kontroll növényeknél is jelentős napszakos ingadozás figyelhető meg az aktivitásban. Jelen kísérleteinkben ezt a jelenséget figyelhetjük meg a szuperoxid gyökaniont $\mathrm{H}_{2} \mathrm{O}_{2}$-dá alakító $\mathrm{SOD}$, illetve kisebb mértékben a $\mathrm{H}_{2} \mathrm{O}_{2}$-ot bontó KAT esetén a gyökérben, valamint a SOD, POD és APX esetében a levelekben.

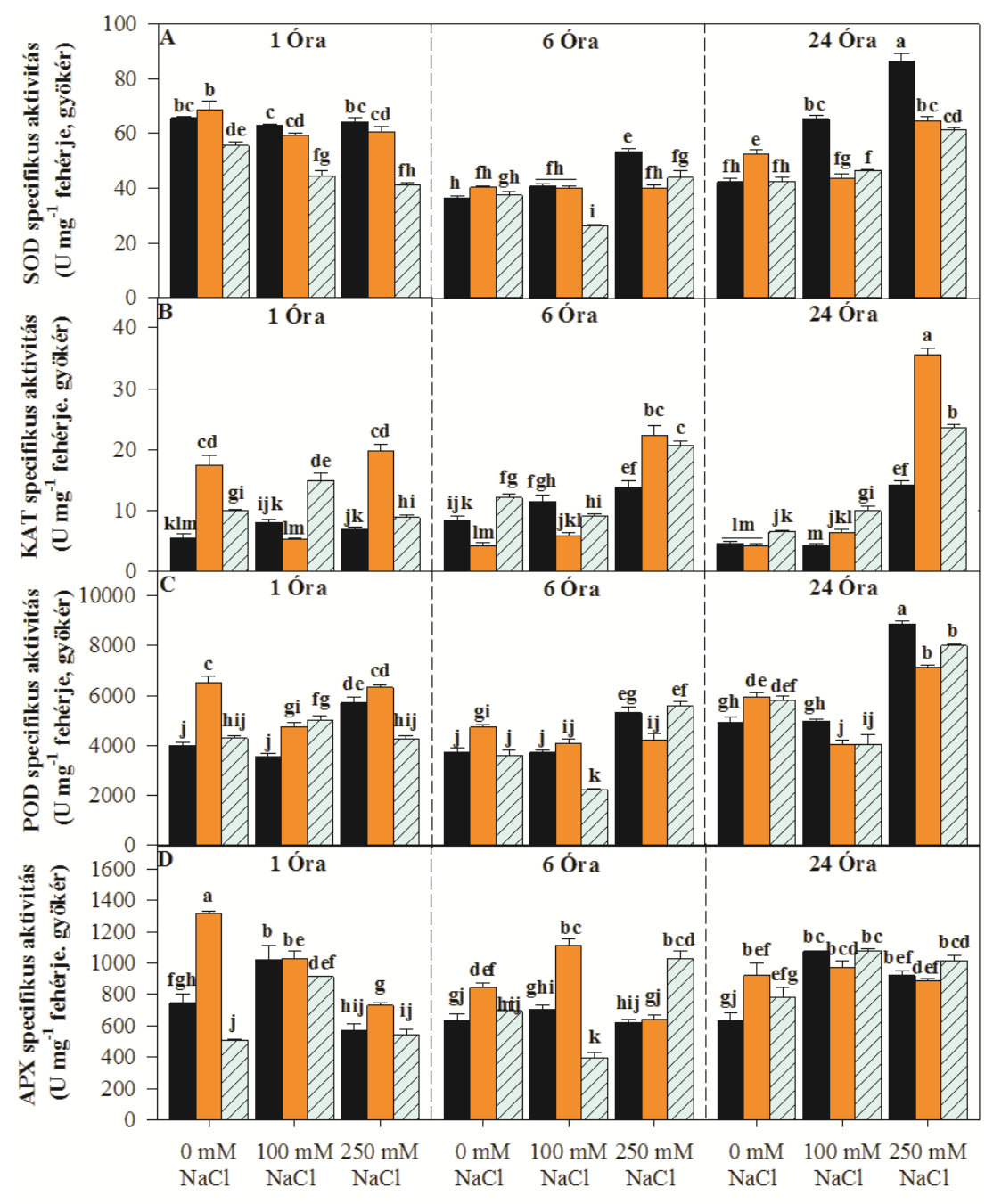

24. ábra SOD (A), KAT (B), POD (C), illetve APX (D) specifikus aktivitás VT (fekete oszlopok) és $N r$ mutáns (ferdecsíkos, halványkék oszlopok) ( $0 \mu \mathrm{M}$ ACC), valamint $10 \mu \mathrm{M}$ ACC-vel kezelt VT (narancssárga oszlopok) paradicsomgyökerekben a $100 \mathrm{mM}$ ill. $250 \mathrm{mM}$-os $\mathrm{NaCl}$ hozzáadását követő 1, 6, ill. 24 óra elteltével. A kísérlet kezdő időpontja a VT növények ACC kezelése 1. órájának leteltétől számítva. Átlag $+\mathrm{SE}, \mathrm{n}=3$. A különböző betűvel jelölt értékek szignifikáns különbségeket mutatnak $\mathrm{P} \leq 0,05$ szinten (SNK teszt).

$\mathrm{Az}$ exogén ACC kezelés önmagában, rövid idő alatt, jelentős mértékben indukálta bizonyos $\mathrm{H}_{2} \mathrm{O}_{2}$ detoxifikáló enzimek, a KAT (24. ábra, B) a POD (24. ábra, C) és az APX (24. ábra, D) specifikus aktivitását a VT gyökerekben, ami az utóbbi két enzim esetében, az idő elörehaladtával is magasabb szinten maradt (24. ábra, A). A $N r$ mutáns gyökereiben is felfedezhetőek időfüggő fluktuációk a vizsgált antioxidáns enzimek aktivitásában. 
A gyökerek SOD aktivitása nem változik a sókezelések hatására rövid távon, sem a VT sem az ACC-kezelt gyökerekben. Ugyanakkor $250 \mathrm{mM} \mathrm{NaCl}$ hatására, a VT növényekben már 6 óra, 100 mM hatására pedig 24 óra múlva jelentősen megemelkedik, melyet az ACC kezelés megakadályoz. A $N r$ mutánsokban a SOD enzimaktivitás valamennyi sókezelt minta esetén szignifikánsan kisebb, mint a sókezelt VT esetében. (24. ábra, A).

A specifikus KAT aktivitás a VT gyökerekben 6 óra után kezd emelkedni $250 \mathrm{mM} \mathrm{NaCl}$ kezelésnél, míg a szubletális sóstressz nem okozott jelentős változást. Az exogén ACC kezelés, szubletális $\mathrm{NaCl}$ koncentráció mellett eleinte mérsékelte, majd kissé fokozta, míg $250 \mathrm{mM}$ só jelenlétében drasztikusan megemelte a KAT specifikus aktivitását (24. ábra, B), az exogén ACC hiányában, a megfelelő $\mathrm{NaCl}$ expozícióban részesülő VT gyökerekhez képest. A VT gyökerekkel szemben, a $\mathrm{Nr}$ mutánsok fokozottabb KAT aktivitással reagáltak a $100 \mathrm{mM} \mathrm{NaCl}$ jelenlétére az 1. és a 24. órában, mely a letális kezelésnél később jelentkezett (24. ábra, B).

A 100 mM-os NaCl kezelés nem volt szignifikáns hatással a POD specifikus aktivitására a VT gyökerekben, ellentétben az exogén ACC kezelés, illetve a $N r$ mutáció hatásával, ahol a kezdeti serkentés később redukcióba fordult át (24. ábra, C). Letális sóstressz az idő függvényében fokozatosan emelkedő POD aktivitást indukált, amely serkentés kisebb mértékben, de az ACC-kezelt és a $N r$ gyökerekben is megfigyelhető.

A specifikus APX aktivitás a VT növények gyökerében kettős, 1 és 24 órai maximumot mutatott $100 \mathrm{mM} \mathrm{NaCl}$ jelenlétében, míg letális sóstressz hatására csak 24 óra múlva emelkedett meg szignifikánsan az aktivitás. Az exogén ACC fokozta a gyökér APX specifikus aktivitását a letális sókoncentráció hozzáadását követő első, míg a szubletális sóstressz alatti 6. órában (24. ábra, D). A $N r$ mutáció az APX specifikus aktivitásának csökkenését eredményezte az enyhébb sóstressz alatt rövidtávon, míg a $250 \mathrm{mM} \mathrm{NaCl}$ hozzáadását követő 6. órában erős aktivációt tapasztaltunk, mely a 24 . órára lecsengett.

Mint azt említettük, a VT levelekben is megfigyelhetők napszakos ritmusok a mért enzimek specifikus aktivitásában, amelyet bizonyos enzimek esetében, időfüggő módon változtatott meg az exogén ACC kezelés és a $N r$ mutáció is, a legtöbb esetben serkentő hatással (25. ábra). Ez alól kivétel az APX specifikus aktivitás, ahol a megváltozott ET státusz, egyébként optimális körülmények között bizonyos mértékű gátlást eredményezett (25. ábra, D).

A sókezelések hatására a SOD aktivitás megemelkedett a VT levelekben, mely a szubletális sóstressz esetében a 6. óránál, míg a letális sókoncentráció jelenlétében a 24 . órát követően mutatott maximumot. $100 \mathrm{mM} \mathrm{NaCl-dal} \mathrm{kombinálva} \mathrm{az} \mathrm{ACC} \mathrm{számottevően} \mathrm{nem}$ befolyásolta a SOD működését a megfelelő sókezelésben részesített VT növények leveleihez képest (25. ábra, A). Ezzel szemben, az extra ACC a letális só-sokk 6. órájában fokozta, míg a 
24. órában kissé mérsékelte a SOD aktivitást. A $N r$ mutáns levelek is hasonló tendenciát mutattak, bár a 250 mM-os $\mathrm{NaCl}$ hozzáadását követő 24. órában, a SOD specifikus müködés gyengülése esetükben jóval hangsúlyosabb volt.

Érdekes módon a levél specifikus KAT aktivitása csak a szubletális sóstressz alatt emelkedett meg az 1. órában, a $250 \mathrm{mM}$-os sókezelés 24. órájától viszont jelentősen gátlódott a kezeletlen kontrollhoz képest. A KAT specifikus aktivitást csak kis mértékben befolyásolta az exogén ACC szubletális só kezelés során (25. ábra B).

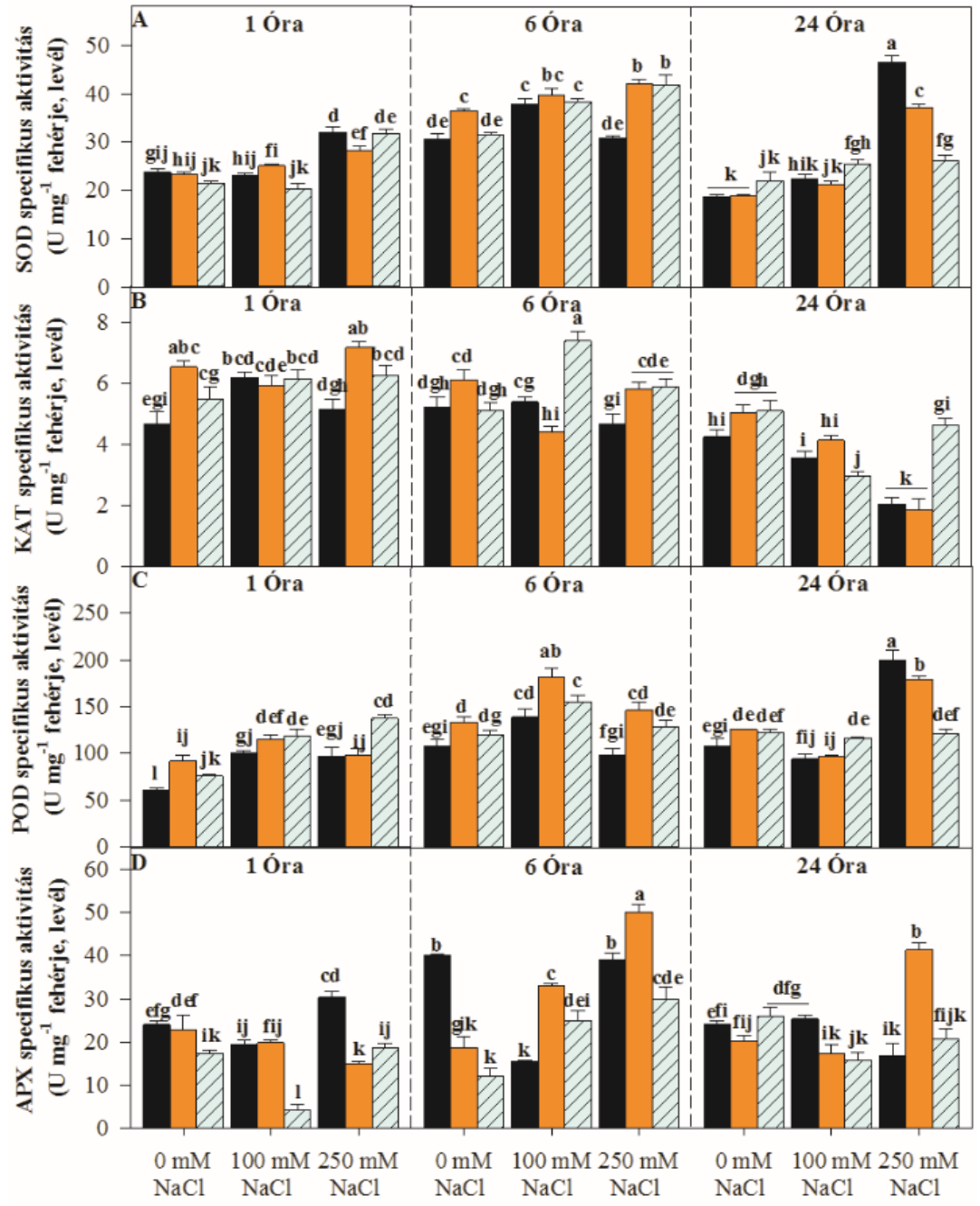

$\square \mathrm{VT} \square \mathrm{VT}+10 \mu \mathrm{MACC} \square / \mathrm{Nr}$

25. ábra SOD (A), KAT (B), POD (C), illetve APX (D) specifikus aktivitás VT (fekete oszlopok) és $N r$ mutáns (ferdecsíkos, halványkék oszlopok) ( $0 \mu \mathrm{M}$ ACC), valamint $10 \mu \mathrm{M}$ ACC-vel kezelt VT (narancssárga oszlopok) paradicsomnövények leveleiben, a $100 \mathrm{mM}$ ill. $250 \mathrm{mM} \mathrm{NaCl}$ hozzáadását követő 1, 6, ill. 24 óra elteltével. A kísérlet kezdő időpontja a VT növények ACC kezelése 1. órájának leteltétől számítva. Átlag $+\mathrm{SE}, \mathrm{n}=3$. A különböző betűvel jelölt értékek szignifikáns különbségeket mutatnak $\mathrm{P} \leq 0,05$ szinten (SNK teszt).

Bár a $\mathrm{Nr}$ mutáns levelekben a $100 \mathrm{mM}$-os $\mathrm{NaCl}$ kezelés 6. órájában jelentősen aktívabb a KAT, 24 órát követően komoly visszaesést tapasztaltunk a megfelelő sókezelésben részesült VT növények leveleihez képest. Érdekes módon, az ACC kezeléssel kombinált $250 \mathrm{mM} \mathrm{NaCl}$ kitettség 1 óra múltán erőteljes KAT aktivitás serkentést váltott ki a levelekben, továbbá 
esetükben időben később jelentkezett a letális sóstressz okozta KAT specifikus aktivitás gátlás, mely a $N r$ mutánsok leveleiben egyáltalán nem következett be (25. ábra B).

A sókezelésekre a VT levelek szignifikáns POD aktivitás növekedéssel reagáltak, amelyek maximuma az alacsonyabb sókoncentrációnál korábban, míg letális sóstressznél 24 óra múlva jelentkezett (25. ábra, C). Ezt az 100 mM-os NaCl kezelés során az exogén ACC enyhén, de szignifikánsan növelte a 6 óráig, míg a $N r$ levelekben a hatás tartósabb. Bár a letális sókezelés 1 órát követően tovább fokozta a POD müködését a $\mathrm{Nr}$ levelekben, később a mutáció gátló hatásúnak bizonyul az enzim specifikus aktivitására.

A levél esetében a sókezelések a legjelentősebb ingadozást az APX aktivitásában okozták, melyre komoly hatással bírt a növények ET státusza. A VT növények leveleiben a 100 mM-os $\mathrm{NaCl}$ kezelés 6 óra után több mint 50\%-os aktivitás esést eredményezett az APX specifikus aktivitásban (25. ábra, D), mely a $N r$ levelekben sokkal drasztikusabb mértékben, már 1 óra múltán megfigyelhető volt. Ennek ellenére, a 6 óránál tapasztalt, $100 \mathrm{mM}$-os $\mathrm{NaCl}$ általi gátlás kisebb mértékű volt a $N r$ mutánsban, még csekélyebb exogén ACC jelenlétében. Letális sóstressz során azonban mind a $N r$ mutáns levelekben, mind az ACC expozícióban részesülö VT növények esetében elmaradt az APX aktivitás só-indukálta fokozódása az 1 órás mintavételi időpontban. Ezzel szemben, a $250 \mathrm{mM} \mathrm{NaCl} \mathrm{okozta} \mathrm{sóstressz} \mathrm{6.} \mathrm{illetve} \mathrm{24.} \mathrm{órájában,}$ az exogén ACC jelenléte serkentő hatással bírt az APX működésére, bár a későbbi időpontban sokkal hangsúlyosabb, több, mint 100\%-os növekedést detektáltunk, a megfelelő sókezelésben részesített, VT levelekhez viszonyítva.

\subsection{4 $\mathrm{A} \mathrm{O}_{2}{ }^{\circ-}$ és a $\mathrm{H}_{2} \mathrm{O}_{2}$ lebontásáért felelős antioxidáns enzimek, valamint az SlRBOH1 expresszió só-indukált válaszainak ET- és időfüggése}

Ahogyan az antioxidáns enzimek aktivitásában is megfigyelhető volt, az ET státusz kontroll körülmények között is befolyásolja a különböző izoenzimek génkifejeződését a gyökérben, méghozzá időfüggő módon (26. ábra).

A sókezelés gyors, és a hajtásnál erőteljesebb hatást gyakorolt a gyökér antioxidáns enzimjeinek génexpressziójára. A $N r$ mutáns gyökerekben a VT-nál erösebb SIMnSOD indukciót detektáltunk a sókezelések hatására, azonban ez 24 óra elteltével represszióba fordult át a letális $\mathrm{NaCl}$ koncentráció esetében (26. ábra). Az exogén ACC kezelés a szubletális sóstressz 6. óráját követően visszafogta, míg a $250 \mathrm{mM} \mathrm{NaCl} \mathrm{jelenlétében} \mathrm{indukálta} \mathrm{a} \mathrm{SIMnSOD}$ izoenzim expresszióját, a kizárólag só kezelést kapott VT gyökerekhez viszonyítva.

A KAT izoenzimeket kódoló gének esetében a sóstressz eltérő kinetika mellett okozott repressziót, illetve indukciót a különböző ET státuszú növényekben. Ez jó összhangban van azzal a megfigyeléssel, hogy a KAT izoenzimek expressziója és aktivitása is jelentős napi 
ritmust mutathat. Az SlKAT1-nél VT növények esetében indukció csak a kisebb sókoncentrációnál, 1 óra után történt. A $N r$ gyökerekben az 1 órás mintavételi ponton szintén erős SlKATl indukció volt megfigyelhető, ami a sóstressz erösödésével fordított arányban változott (26. ábra). Ezzel szemben, $100 \mathrm{mM} \mathrm{NaCl} \mathrm{jelenlétében,} \mathrm{az} \mathrm{exogén} \mathrm{ACC} \mathrm{kezelés} \mathrm{mellett}$ is erős SIKAT1 indukciót detektáltunk a VT gyökerekben. Míg a letális sókoncentráció a VT gyökerekben gátolta az SIKAT1 kifejeződését a 6. órában, ez az ACC kezelés mellett enyhébb mértékben, ugyanakkor a $\mathrm{Nr}$ mutánsokban egyáltalán nem volt megfigyelhető.

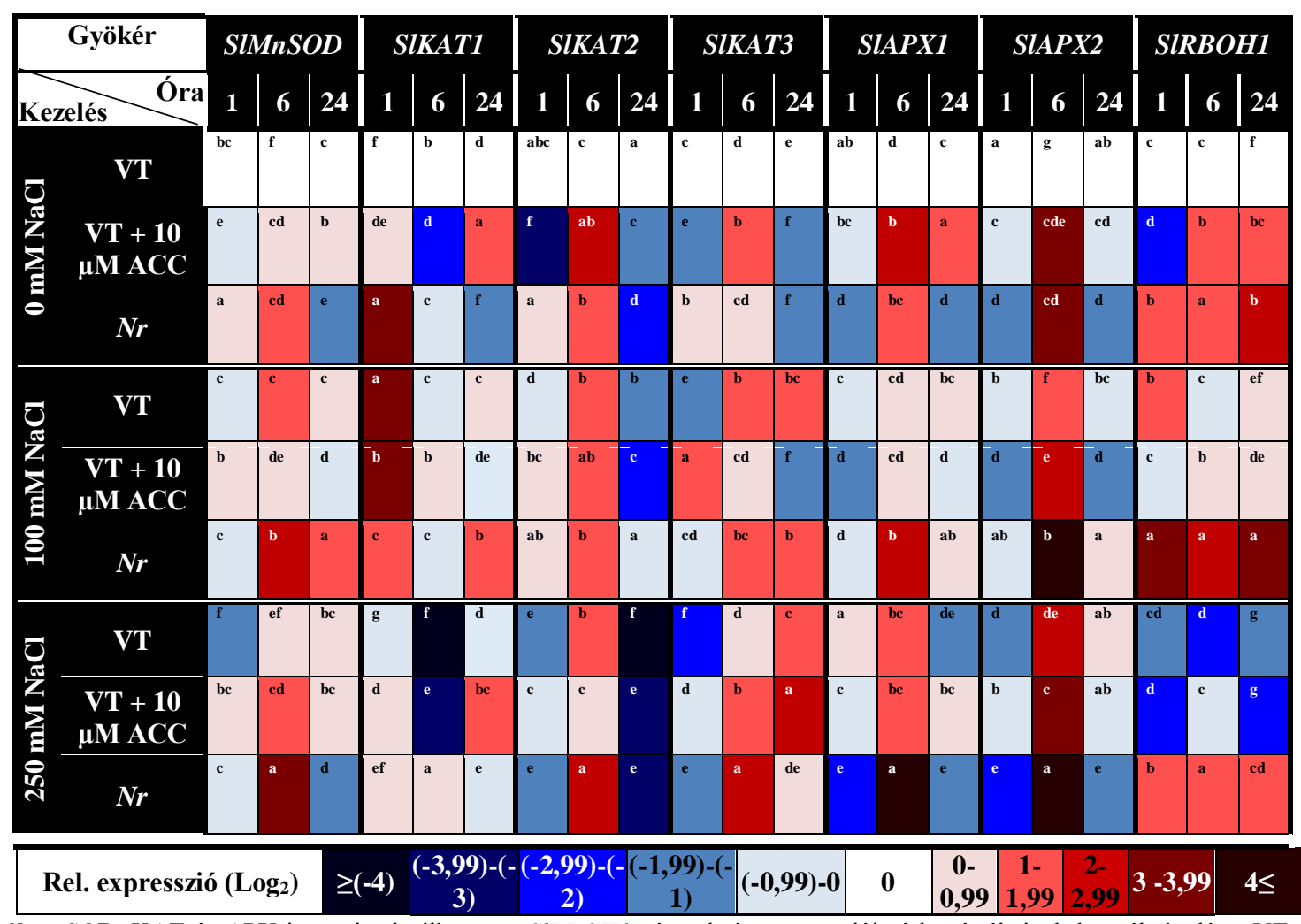

26. ábra SOD, KAT és APX izoenzimek, illetve az SlRBOH1 gén relatív expressziója átlag értékeinek log ábrázolása, VT és $N r$ mutáns $(0 \mu \mathrm{M}$ ACC), valamint $10 \mu \mathrm{M}$ ACC-vel kezelt VT paradicsomnövények gyökereiben, a $100 \mathrm{mM}$ ill. $250 \mathrm{mM}$-os NaCl hozzáadását követő 1, 6, ill. 24 óra elteltével, a hőtérképen megadott skála szerint. A piros színárnyalatok indukciót, a kék ek repressziót jelölnek. A kísérlet kezdő időpontja a VT növények ACC kezelése 1. órájának leteltétől számítva. A különböző betüvel jelölt cellák szignifikáns különbségeket mutatnak $\mathrm{P} \leq 0,05$ szinten az adott időpontokon belül (Duncan teszt). A konkrét számadatok a 3 . mellékletben találhatóak.

Az SIKAT2-re az 1 órás mintákban elsősorban a gén alulmüködése volt jellemző, ez erőteljesebb a letális sóstressznél a VT növények és a $N r$ mutáns esetében, illetve érdekes módon, az exogén ACC kezelés is így hatott a VT kontroll növényekben. A 6 órás mintavételnél a gén expressziója valamennyi kezelés esetén bár különböző mértékben, de növekedett, amely folyamat a 24. órára a represszió irányába fordult. Az exogén ACC SIKAT2 indukáló hatása a 6. órában érvényesült legerőteljesebben, mely a sóstressz erősödésével elhalványult. Ennek ellenére a letális sóstressz során, az exogén ACC mérsékelte az SIKAT2 repressziót, mely 24 óra után a $\mathrm{Nr}$ mutáns gyökerekben is hasonlóan alakult (26. ábra). A $100 \mathrm{mM}$-os NaCl kezelés 
24 óra múltán a VT növényekben is represszálta az SIKAT2 gént, mely érdekes módon nagyobb mértékünek bizonyult az ACC kezelt gyökerekben, viszont a $\mathrm{Nr}$ mutánsokban elmaradt.

Az SIKAT3 génre ugyancsak a sókezelés által rövid távon kiváltott repressziót követő későbbi indukció jellemző, melyet az exogén ACC a 100 mM-os NaCl kezelés esetében megfordított, illetve a $\mathrm{Nr}$ mutánsok esetében a VT gyökerekben megfigyelt, kezdeti represszió elmaradt (26. ábra). A letális sókezelés nagymértékben gátolta az SIKAT3 expressziót 1 óra elteltével a VT gyökerekben, amit az ACC kezelés megakadályozott, majd a 6 órától fokozta a SlKAT3 expressziót. A $N r$ gyökerekben, a VT-al ellentétben, a letális sóstressz 6. órájában figyeltünk meg SlKAT3 aktivációt.

Mindkét APX gén esetében az expressziós maximumokat a kezeléstől függetlenül a fényperiódus közepére eső, 6 órás mintavételeknél kaptuk, az 1 órás és 24 órás mintákban pedig kezelésektől függően, néhány kivételtől eltekintve repressziót detektáltunk. Az SlAPX1 expresszióját a szubletális sóstressz csupán kisebb mértékben befolyásolta (26. ábra). A 250 mM-os $\mathrm{NaCl}$ kezelés okozta 24 órás, SlAPX1 represszió exogén ACC jelenlétében elmaradt. A $N r$ mutáció erősebb SlAPX1 expressziót indukált mindkét típusú sóstressz során, 6 óra elteltével, mely a letális sóstressz esetében jóval nagyobb mértékünek bizonyult. Ezzel szemben, a 250 mM-os $\mathrm{NaCl}$ kezelés többi időpontjában ellentétes hatást fejtett ki.

A sókezelés SlAPX2-t indukáló hatását a 6 órás mintavételkor az ACC kezelés, illetve a $N r$ mutáció tovább fokozta, bár az utóbbi sokkal jelentősebb mértékben (26. ábra). A $N r$ gyökerek SIAPX2 expressziója az SlAPX1-hez hasonlóan alakult letális sóstressz során.

Az SlRBOH1 expressziós változás jellegzetessége, hogy az mindvégig sokkal eröteljesebb a $N r$ gyökerekben, különösen a szubletális sóstressz esetén, és valamennyi mintavételnél a kísérlet végéig megmarad a gén felülreguláltsága (26. ábra). Míg a szubletális $\mathrm{NaCl} 1$ óra elteltével indukálta az SIRBOH1 expressziót VT gyökerekben, addig ez az ACC kezelés hatására elmaradt. A letális sóstressz jelentősen represszálta az $S I R B O H 1$ kifejeződését, mely a 6. órában mutatott minimumot, míg ACC kezelés mellett az 1. és a 24. órás mintavételi ponton erősebb repressziót detektáltunk, ám elmaradt a 6 . órában megfigyelt expressziós gátlás.

A levél ET státusza szintén kihatott - a gyökér eseténél kisebb mértékben - a vizsgált antioxidáns izoenzimek expressziójára stresszfaktor hiányában is, mely leginkább a korai időpontokban jelentkezik (27. ábra). A kloroplasztisz lokalizációjú $S l C u / Z n S O D$ kifejeződés sófüggő indukciót mutatott, ami a másik két izoenzim esetében kevésbé volt hangsúlyos (27. ábra). A sóindukálta $S l C u / Z n S O D$ expresszió a $N r$ mutáns, illetve az ACC kezelt VT növényekben sokkal enyhébb mértékü volt. 
Az exogén ACC a sókezelések során kezdetben serkentette, majd a 24 óra elteltével represszálta a $S l F e S O D$ expressziót, mely jóval erősebb a letális stressz során (27. ábra). Az utóbbi változás a $\mathrm{Nr}$ levelekben is hasonlóan játszódott le.

Az SIMnSOD ACC kezelés által indukált repressziója a sókoncentráció erősödésével egyenes arányban fokozódott. A $250 \mathrm{mM}$-os $\mathrm{NaCl}$ által kiváltott SlMnSOD represszió a VT növényekben a hatodik, a $N r$ levelekben a 24 . órában volt megfigyelhető (27. ábra).

A 100 mM-os NaCl által, a VT levél SIKATl expressziójában kiváltott változásokat nem lehetett megfigyelni ACC kezelés jelenlétében. A Nr mutáció okozta SIKAT1 represszió tovább erősödött a sókezelések 24. óráját követően (27. ábra). A $250 \mathrm{mM}$-os $\mathrm{NaCl}$ indukálta SlKAT1 felülregulációja a $N r$ mutánsokban későbbi időpontban volt megfigyelhető.

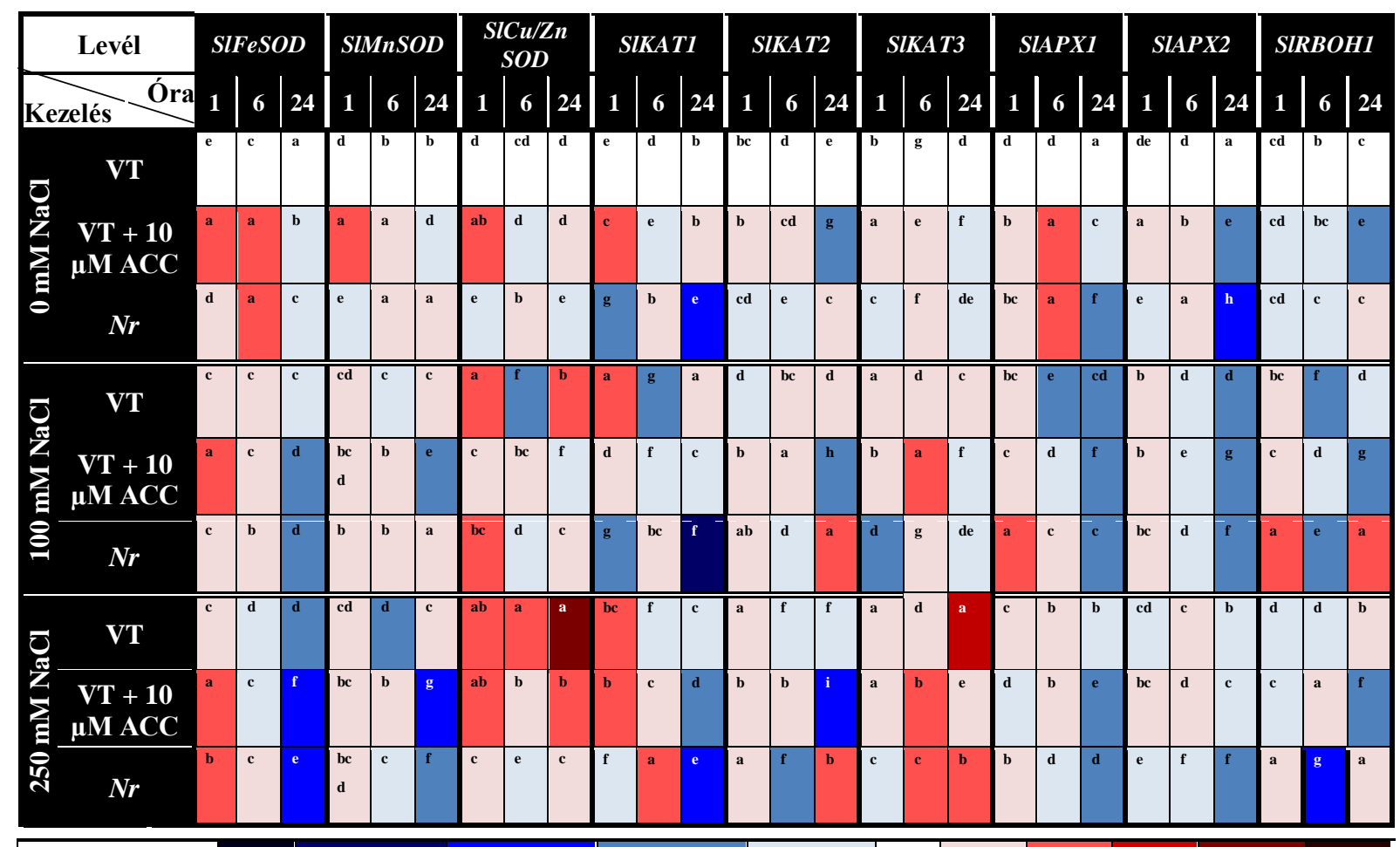

Rel. expresszió $\left(\log _{2}\right)$

$\geq(-4) \quad(-3,99)-(-3) \quad(-2,99)-(-2)$

3 $-3,99$

27. ábra SOD, KAT és APX izoenzimek relatív expressziója átlag értékeinek $\log _{2}$ ábrázolása VT és $N r$ mutáns $(0 \mu \mathrm{M}$ ACC), valamint $10 \mu \mathrm{M}$ ACC-vel kezelt VT paradicsomnövények leveleiben, a $100 \mathrm{mM}$ ill. $250 \mathrm{mM}$-os NaCl hozzáadását követő 1 , 6 , ill. 24 óra elteltével, a hőtérképen megadott skála szerint. A piros színárnyalatok $(1 \leq)$ indukciót, a kékek repressziót $(\leq-1)$ mutatnak. A kísérlet kezdő időpontja a VT növények ACC kezelése 1. órájának leteltétől számítva. A különböző betűvel jelölt cellák szignifikáns különbségeket mutatnak $\mathrm{P} \leq 0,05$ szinten az adott időpontokon belül (Duncan teszt). A konkrét számadatok a 4 . mellékletben találhatóak.

Érdekes módon, az SIKAT2 expresszió nem mutatott komolyabb sófüggőséget $\mathrm{Nr}$ mutáció vagy ACC kezelés hiányában, az előbbi jelenlétében azonban 24 óra elteltével indukálódott, míg az ACC okozta SlKAT2 represszió felerősödött a $250 \mathrm{mM} \mathrm{NaCl} \mathrm{kezelés}$ időartamának a végére (27. ábra). 
Az SIKAT3 fokozott expressziót mutatott a letális sóstressz 24. óráját követően, mely az ACC kezelés hatására a 6 órás mintavételi időpontban jelentkezett. A letális sóstressz indukálta SIKAT3 kifejeződés a $N r$ levelekben hamarabb jelentkezett, mint a VT esetében (27. ábra).

A 100 mM-os $\mathrm{NaCl}$ kezelés már a 6. órától represszálta az SlAPX1 expressziót a VT levélben, mely az ACC kezelt, valamint a $N r$ mutáns növényekben később jelentkezett. Ugyanakkor a letális sóstressz 24. óráját követően az SIAPX1 erősebben represszálódott a két utóbbi csoport esetében (27. ábra).

A szubletális sókoncentráció által, a 24. órában okozott SlAPX2 repressziót a vizsgált időpontokban nem befolyásolta a levelek ET státusza. A letális sóstressz során a $N r$ mutáció az SlAPX2 expressziót is csökkentette a levélben, 24 óra elteltével (27. ábra).

A 100 mM-os $\mathrm{NaCl}$ jelenlétében, az SIRBOH1 expresszióját a $N r$ mutáció az 1. és 24. órában indukálta, míg az exogén ACC kezelés az utóbbi időpontban gátolta. Letális sóstressz során az exogén ACC, valamint a $N r$ mutáció inkább represszálja az SIRBOH1-gyet (27. ábra)

\subsubsection{A fotoszintézis és az összcukor-, valamint keményítőtartalmak só-indukált válaszainak ET- és időfüggése}

Mivel a növekedési adatok nem mutattak szignifikáns különbséget a különböző ET státuszú növények sóstressz-érzékenysége között, ami az oxidatív stressz vonatkozásában az előző fejezetben leírtaknak megfelelően mindenképpen fennáll, ezért megvizsgáltuk növények fotoszintézisének gyors változását is a kezeléseket követő első 24 órában. Ez szintén alkalmas lehet a növények sóstressz-érzékenységének összehasonlítására.

Az exogén ACC kezelés enyhén, de szignifikáns módon fokozta a kezeletlen VT paradicsomlevelek $A_{N}$ értékeit is az 1. és a 24. órás mérési időpontban (28. ábra, A). Bár a $N r$ levelek $\mathrm{CO}_{2}$ fixációja jelentősen alacsonyabb mértékü, mint a VT növények esetében, a 24. órás mintavételi ponton ez a különbség nem bizonyult szignifikánsnak.

A gyökérzóna megemelkedett sókoncentrációja 1 óra alatt szignifikánsan csökkentette az $\mathrm{A}_{\mathrm{N}}$ - $\mathrm{t}$ a VT levelekben. Míg a szubletális $\mathrm{NaCl}$ koncentráció mellett, az ACC-kezelt és a $\mathrm{Nr}$ növények még képesek voltak megtartani a fotoszintetikus aktivitásukat, addig ez letális sóstressz esetén már 1 óra után sem volt megfigyelhető (28. ábra, A). A 6. órára a megfelelö sókezelésben részesült VT értékektől való eltérések elhalványultak a $100 \mathrm{mM}$-os $\mathrm{NaCl}$ kezelés esetében, viszont a 24. órát követően az $\mathrm{A}_{\mathrm{N}}$ szignifikánsan lecsökkent a $N r$ levelekben. Érdekes módon, míg eleinte a $N r$ mutánsok fotoszintézise válaszolt a legérzékenyebben a gyökér környezetében kialakuló, $250 \mathrm{mM} \mathrm{NaCl}$ okozta sokkhatásra, a 6. órára képes volt kissé jobban megőrizni a $\mathrm{CO}_{2}$ asszimilációját, mint a másik két kísérleti csoport. 24 óra elteltével, a VT növények $A_{N}$ értékeinek negatívba való átcsapása volt megfigyelhető, ellentétben az ACC 
kezelt VT és a $N r$ mutáns levelekkel, melyek egy, a kezeletlen kontroll értékhez képest ugyan jóval kisebb, de mérhető $\mathrm{CO}_{2}$ fixációs aktivitással rendelkeztek (28. ábra, A).

A $g_{s w}$ változásai többnyire jól követték az $A_{N}$ esetében megfigyelt tendenciákat, néhány kivétellel. Az exogén ACC kezelés képes volt jobban megőrizni a $\mathrm{g}_{\mathrm{sw}}$-t a sókezelések 1. óráját követően (28. ábra, B). A $N r$ mutánsok a VT-nál eleve alacsonyabb g $\mathrm{g}_{\mathrm{sw}}$ értékkel rendelkeztek, mely különbség gyakorlatilag eltünt a $250 \mathrm{mM}-\mathrm{os} \mathrm{NaCl}$ jelenlétében. $\mathrm{A} \mathrm{C}_{\mathrm{i}} / \mathrm{C}_{\mathrm{a}}$ arány esetében elmondható, hogy többnyire követte a $g_{s w}$-ben megfigyelt változásokat (28. ábra, C). Ez alól kivételt képez a letális sókezelést követő 6. illetve 24. óra, ahol a VT levelekben drasztikus emelkedést figyeltünk meg a $\mathrm{C}_{\mathrm{i}} / \mathrm{C}_{\mathrm{a}}$ értékekben. Az ACC-kezelt növényekben, ugyanúgy, ahogy a $\mathrm{Nr}$ levelek esetében a 24 órás mérési időpontban a kezeletlen kontrollal megegyező értékeket detektáltunk. Fontos megjegyezni, hogy a $N r$ levelekben a $\mathrm{C}_{\mathrm{i}} / \mathrm{C}_{\mathrm{a}}$ már jelentősen csökkent a 250 $\mathrm{mM} \mathrm{NaCl}$ kezelés 6. óráját követően is.

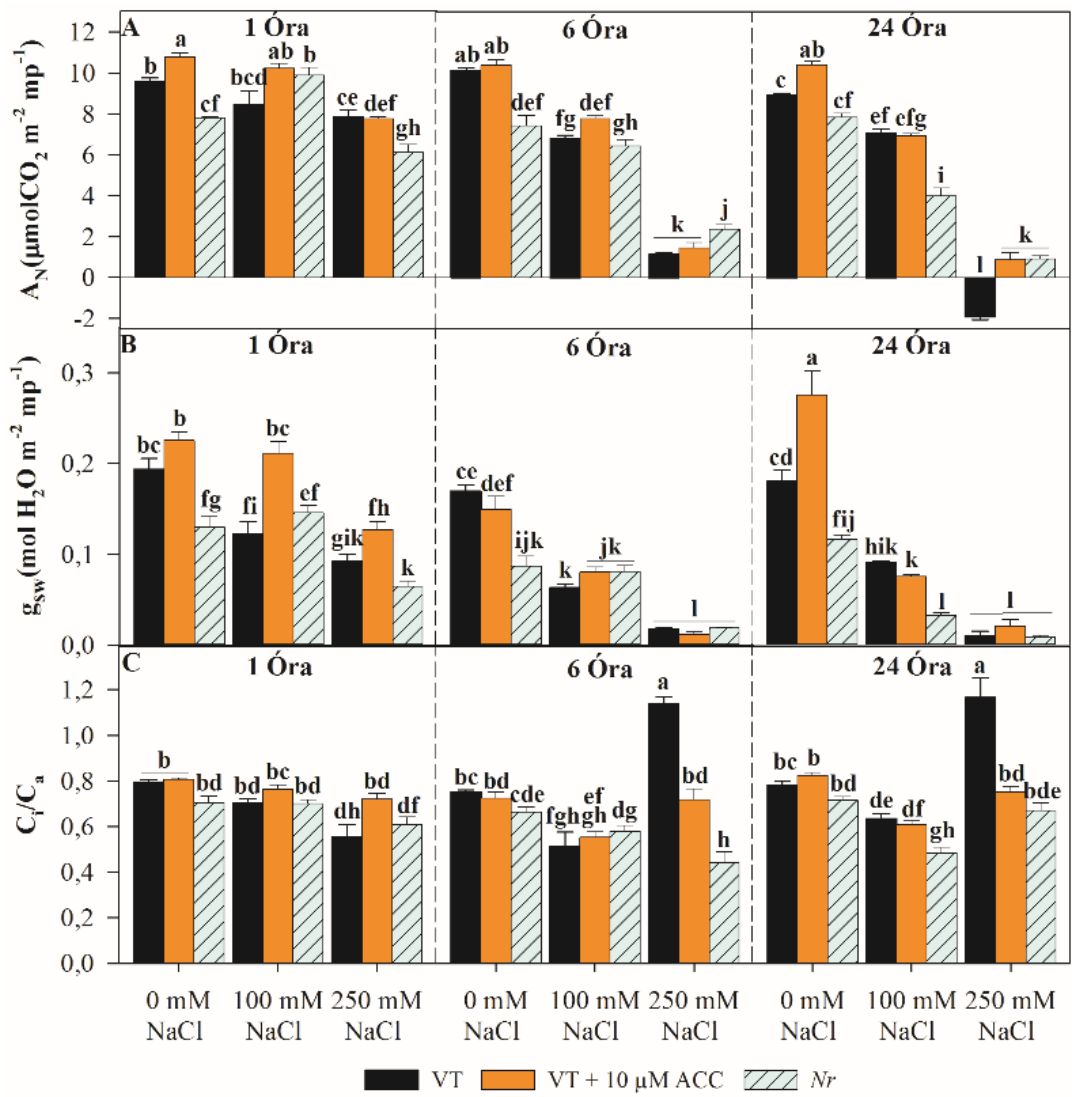

28. ábra $\mathrm{A} \mathrm{CO}_{2}$ asszimiláció és a kapcsolódó paraméterek VT (fekete oszlopok) és $\mathrm{Nr}$ mutáns (ferdecsíkos, halványkék oszlopok) (0 $\mu \mathrm{M}$ ACC), valamint $10 \mu \mathrm{M} \mathrm{ACC}$-vel kezelt VT (narancssárga oszlopok) paradicsomnövények leveleiben 1, 6, ill. 24 órás $100 \mathrm{mM}$ ill. $250 \mathrm{mM} \mathrm{NaCl}$ expozíciót követően. A: a nettó $\mathrm{CO}_{2}$ asszimilációs ráta, $\mathrm{A}_{\mathrm{N}} ; \mathrm{B}$ : a sztómák vízgőzvezető képessége, $\mathrm{g}_{\mathrm{sw}} ; \mathrm{C}$ : az intercelluláris és az atmoszférikus $\mathrm{CO}_{2}$ koncentráció aránya, $\mathrm{C}_{\mathrm{i}} / \mathrm{C}_{\mathrm{a}}$. A kísérlet kezdő időpontja a VT növények ACC kezelése 1. órájától számítva. Átlag + SE, $n=6$. A különbözö betủvel jelölt értékek szignifikáns különbségeket mutatnak a kezelések és az eltérő időpontok között $\mathrm{P} \leq 0,05$ szinten (SNK teszt).

A PSII stabilitásának vizsgálata során nem tapasztaltunk számottevő csökkenést a levelek $\mathrm{F}_{\mathrm{V}} / \mathrm{F}_{\mathrm{M}}$ paramétereiben a kísérlet során, kivéve az enyhe, de szignifikáns csökkenést a 
24 órás, $250 \mathrm{mM}$-os $\mathrm{NaCl}$ kezelést követően a $N r$ mutánsok esetében (29. ábra, $\mathrm{A}$ ). $\mathrm{Az} \mathrm{F}_{0}$ paraméter sem mutatott szignifikáns eltéréseket (29. ábra, B).

A két fotokémiai rendszer érzékenysége kisebb eltéréseket mutatott a különböző kísérleti csoportokban a sóstressz alatt. A szubletális mértékü $\mathrm{NaCl}$ kezelés szignifikánsan csökkentette a $N r$ növények Y(II) értékeit már az 1. órától, illetve a letális só sokk a 6. órától, ami több, mint 60\%-os eséssé alakult a 24. órát követően (30. ábra, A), míg a $100 \mathrm{mM}$-os $\mathrm{NaCl}$ koncentráció nem okozott számottevő Y(II) redukciót a többi, vizsgált csoportban. Ezzel szemben, a 250 mM-os $\mathrm{NaCl}$ tápoldatbéli jelenléte szignifikánsan csökkentette a VT növények Y(II) értékeit 6 órás kitettséget követően, melyet az exogén ACC kezelés sikeresen kivédett.

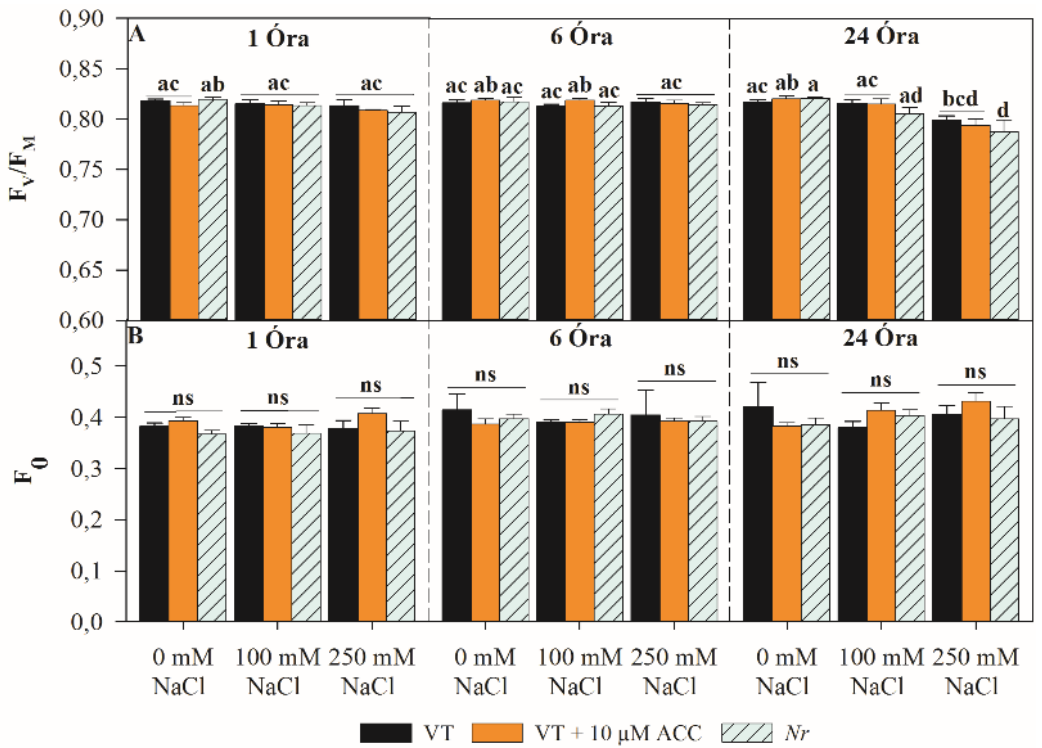

29. ábra A PSII állapotára vonatkozó klorofill $a$ fluoreszcencia paraméterek alakulása VT (fekete oszlopok) és $N r$ mutáns (ferdecsíkos, halványkék oszlopok) ( $0 \mu \mathrm{M} \mathrm{ACC}$ ), valamint $10 \mu \mathrm{M}$ ACC-vel kezelt VT (narancssárga oszlopok) paradicsomnövények leveleiben 1, 6, ill. 24 órás $100 \mathrm{mM}$ ill. $250 \mathrm{mM} \mathrm{NaCl}$ expozíciót követően. A: a PSII maximális kvantumhatásfoka sötétadaptált levelekben $\left(\mathrm{F}_{\mathrm{v}} / \mathrm{F}_{\mathrm{M}}\right)$; B: a sötétadaptált levelek minimális fluoreszcenciája $\left(\mathrm{F}_{0}\right)$. A kísérlet kezdő időpontja a VT növények ACC kezelése 1. órájától számítva. Átlag $+\mathrm{SE}, \mathrm{n}=5$. A különbözö betűvel jelölt értékek szignifikáns különbségeket mutatnak a kezelések és az eltérő időpontok között $\mathrm{P} \leq 0,05$ szinten, $\mathrm{ns}=$ nem szignifikáns $($ SNK teszt).

A VT növények a letális sókoncentráció hatására szignifikáns Y(NPQ) emelkedést mutattak a 6. órától, míg ez nem volt megfigyelhető a szubletális stressz esetén. A $N r$ mutánsok eleve magasabb Y(NPQ) értékekkel rendelkeztek (30. ábra, B), mely a $100 \mathrm{mM}$-os $\mathrm{NaCl}$ kezelést követő 1 . órában nem változott, míg a $250 \mathrm{mM}$-os $\mathrm{NaCl}$ kezelés esetében visszaesett a kontroll értékre. Ugyanakkor, a sóstresszes állapot kifejlődése során, a $\mathrm{Nr}$ levelek VT levelekhez képest nagyon erős Y(NPQ) aktivációval reagáltak, mely a szubletális stressz során maximumot mutatott 6 órát követően, a letális sóstressz esetében viszont a 24. órára még tovább nőtt. Bár a $10 \mu \mathrm{M}$ ACC jelenlétében szubletális stressz során nem tapasztaltunk jelentős Y(NPQ) növekedést a VT levelekben, azonban az ACC kezelés kontroll szinten tartotta az egyébként lecsökkenő $\mathrm{Y}(\mathrm{NPQ})$-t a 6. órát követően, továbbá, a letális só sokk által növelt Y(NPQ) mértékét is szignifikánsan visszafogta. Ezzel szemben, a 24. órában már nem okozott 
eltérést a $250 \mathrm{mM} \mathrm{NaCl}$ által megemelt $\mathrm{Y}(\mathrm{NPQ})$ értékében. A Y(NO) esetében nem tapasztaltunk jelentős növekedést a kísérletek során (30. ábra, C).

A gyökérközegben jelen lévő, szubletális sókoncentráció szignifikánsan csökkentette a $N r$ mutánsok qL értékét a sókezelt VT értékeihez képest már az 1. és a 24. órában, akárcsak a letális sóstressznél 6 óra elteltével (30. ábra, D). Míg a VT növények qL értékeit az 1. és a 24. órában a sókezelések nem befolyásolták, addig a 6. órában bekövetkezö, természetes qL csökkenést a $250 \mathrm{mM} \mathrm{NaCl}$ megfordította, ugyanúgy, ahogyan az exogén ACC is önmagában és $100 \mathrm{mM} \mathrm{NaCl}$ jelenlétében. Ennek ellenére, az ACC kezelés enyhe, de szignifikáns qL csökkenést okozott a hasonlóan kezelt VT kontrollhoz képest a letális sókoncentráció 1. órás mintájában, mely fennmaradt egészen a 24 . óráig.

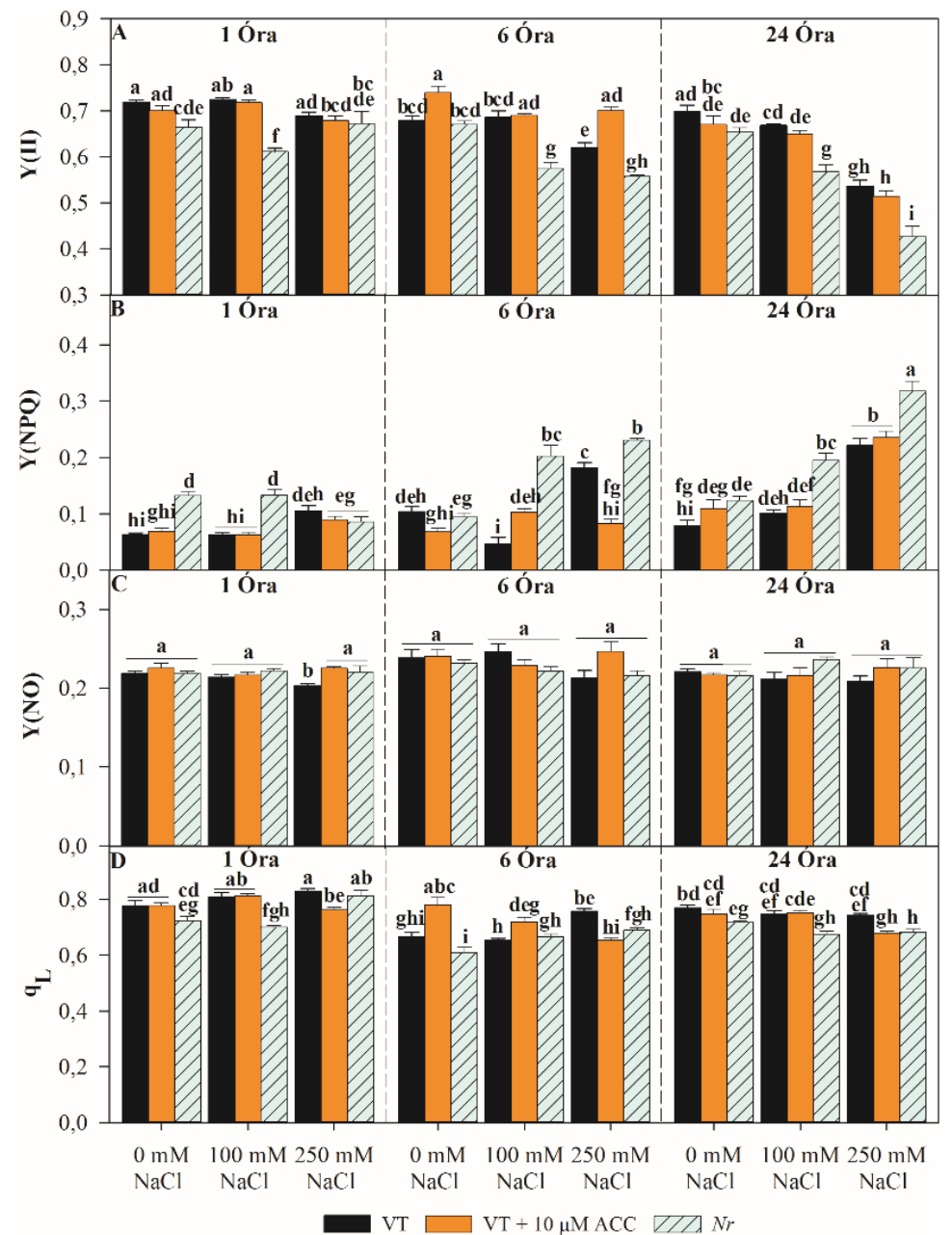

30. ábra A PSII aktivitásával és szabályozásával kapcsolatos klorofill $a$ fluoreszcencia paraméterek VT (fekete oszlopok) és $N r$ mutáns (ferdecsíkos, halványkék oszlopok) $(0 \mu \mathrm{M} \mathrm{ACC})$, valamint $10 \mu \mathrm{M} \mathrm{ACC-vel} \mathrm{kezelt} \mathrm{VT} \mathrm{(narancssárga} \mathrm{oszlopok)} \mathrm{paradicsomnövények}$ leveleiben 1, 6, ill. 24 órás $100 \mathrm{mM}$ ill. $250 \mathrm{mM} \mathrm{NaCl}$ expozíciót követően. A: a PSII effektív kvantumhatásfoka fényadaptált levelekben, Y(II); B: a (fény)szabályozott energia disszipáció kvantumhatásfoka, Y(NPQ); C: a szabályozatlan energia disszipáció kvantumhatásfoka, Y(NO); D: valamint a fényadaptált PSII reakciócentrumok nyitott állapotú frakciója, qL. A kísérlet kezdő időpontja a VT növények ACC kezelése 1. órájától számítva. Átlag $+S E, n=5$. A különböző betűvel jelölt értékek szignifikáns különbségeket mutatnak a kezelések és az eltérö időpontok között $\mathrm{P} \leq 0,05$ szinten ( $\mathrm{SNK}$ teszt).

A Y(I) nem változott az ACC hiányában adott sókezeléseknél a 6. óráig, a VT ill. a $\mathrm{Nr}$ mutáns növények esetében. Az exogén ACC kezelés sem okozott szignifikáns változást a Y(I)- 
ben a VT-hoz képest, sem önmagában, sem 100 mM NaCl kezeléssel kombinálva (31. ábra, A). A 24. órában viszont a letális hatású sókezelés szignifikánsan csökkentette a Y(I)-t, mely a $\mathrm{Nr}$ mutánsok esetében már a $100 \mathrm{mM} \mathrm{NaCl}$ jelenlétében is megtörtént, csak ez esetben a stressz erőssége a csökkenés mértékét is növelte. Érdekes módon, az ACC kezelés itt tovább fokozta a letális só okozta $\mathrm{Y}(\mathrm{I})$ redukciót.

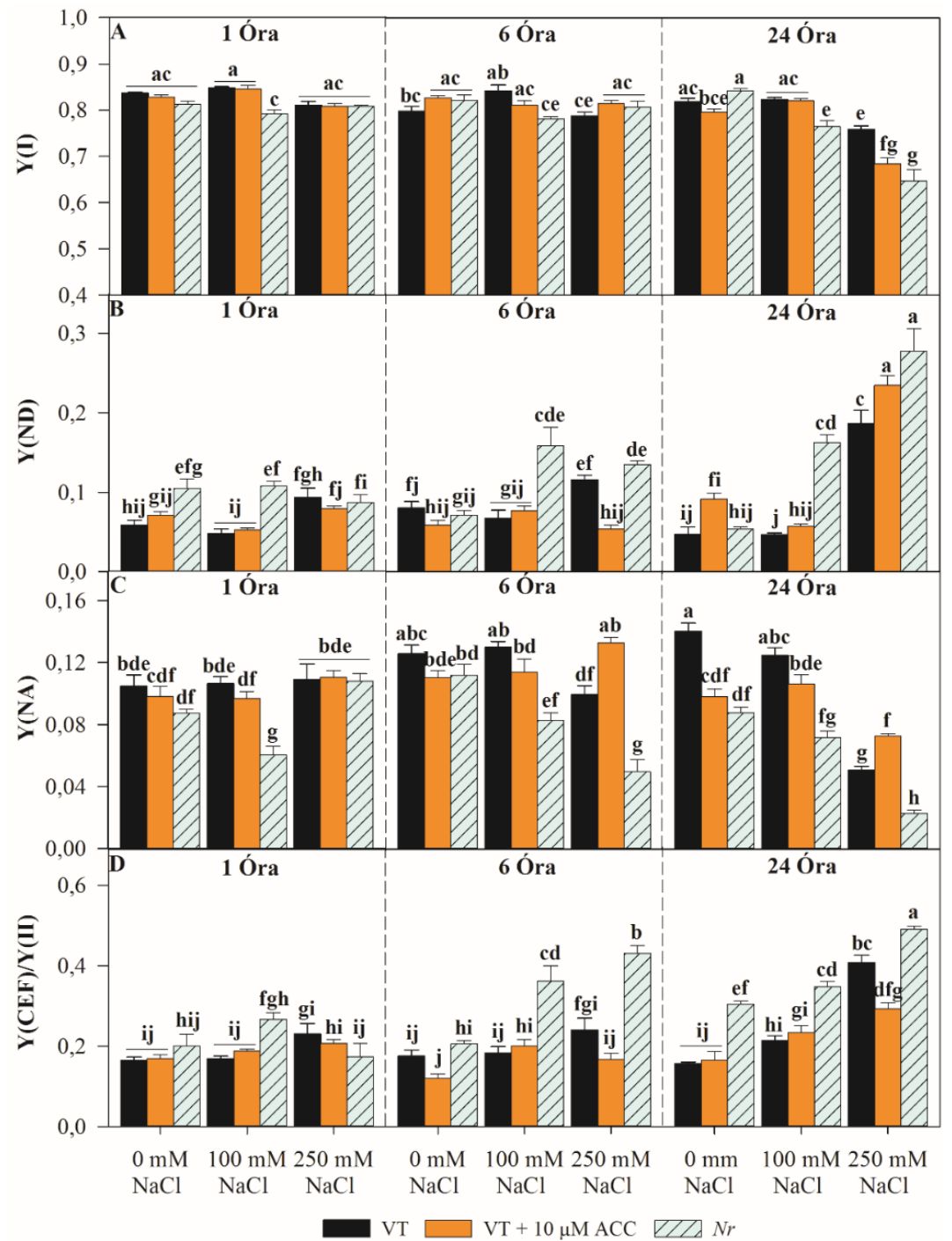

31. ábra A PSI aktivitásával és szabályozásával kapcsolatos paraméterek VT (fekete oszlopok) és $N r$ mutáns (ferdecsíkos, halványkék oszlopok) ( $0 \mu \mathrm{M}$ ACC), valamint $10 \mu \mathrm{M}$ ACC-vel kezelt VT (narancssárga oszlopok) paradicsomnövények leveleiben 1, 6, ill. 24 órás $100 \mathrm{mM}$ ill. $250 \mathrm{mM} \mathrm{NaCl}$ expozíciót követöen. A: a PSI fotokémiai kvantumhatásfoka fényadaptált levelekben, Y(I); B: a PSI donor oldali limitációjából fakadó nem fotokémiai kioltás kvantumhatásfoka, Y(ND); C: a PSI akceptor oldali limitációjából fakadó nem fotokémiai kioltás kvantumhatásfoka, Y(NA); D: valamint a PSI körüli ciklikus elektronáramlás kvantumhatásfokának többlete, $\mathrm{Y}(\mathrm{CEF}) / \mathrm{Y}(\mathrm{II})$. A kísérlet kezdő időpontja a VT növények ACC kezelése 1. órájától számítva. Átlag + SE, $\mathrm{n}=5$. A különböző betűvel jelölt értékek szignifikáns különbségeket mutatnak kezelések és az eltérő időpontok között $\mathrm{P} \leq 0,05$ szinten (SNK teszt).

A Y(ND) alakulása jól követte a PSII nem-fotokémiai kioltásában megfigyelt tendenciális változásokat (31. ábra, B). A legnagyobb növekményt a sókezelt, $\mathrm{Nr}$ mutánsok Y(ND) értékeiben figyeltük meg, amely egyidejüleg sókoncentráció és időfüggést is mutatott. A Y(NA) azonban szignifikánsan alacsonyabb értékeket vett fel az $N r$ mutánsokban már a 100 $\mathrm{mM} \mathrm{NaCl}$ kezelés első órája után (31. ábra, C). Érdekes módon, ezt a jelenséget a letális 
sóstressz esetében csupán a 6. órától kezdve sikerült megfigyelni, bár ez esetben a csökkenés drasztikusabb volt és tovább folyatódott az idő elörehaladtával.

A $N r$ mutánsokban a Y(NA) kezdeti állapota a kezeletlen VT-nál alacsonyabb, mely a VT napszakos Y(NA) fluktuációja miatt a későbbi időpontokban nem mutatkozott szignifikánsnak (31. ábra, C). A letális sóstressz 6. órájától megfigyelhető Y(NA) csökkenést az ACC kezelés szignifikáns mértékben megfordította a VT levelekben, ami a kísérlet végéig megmaradt.

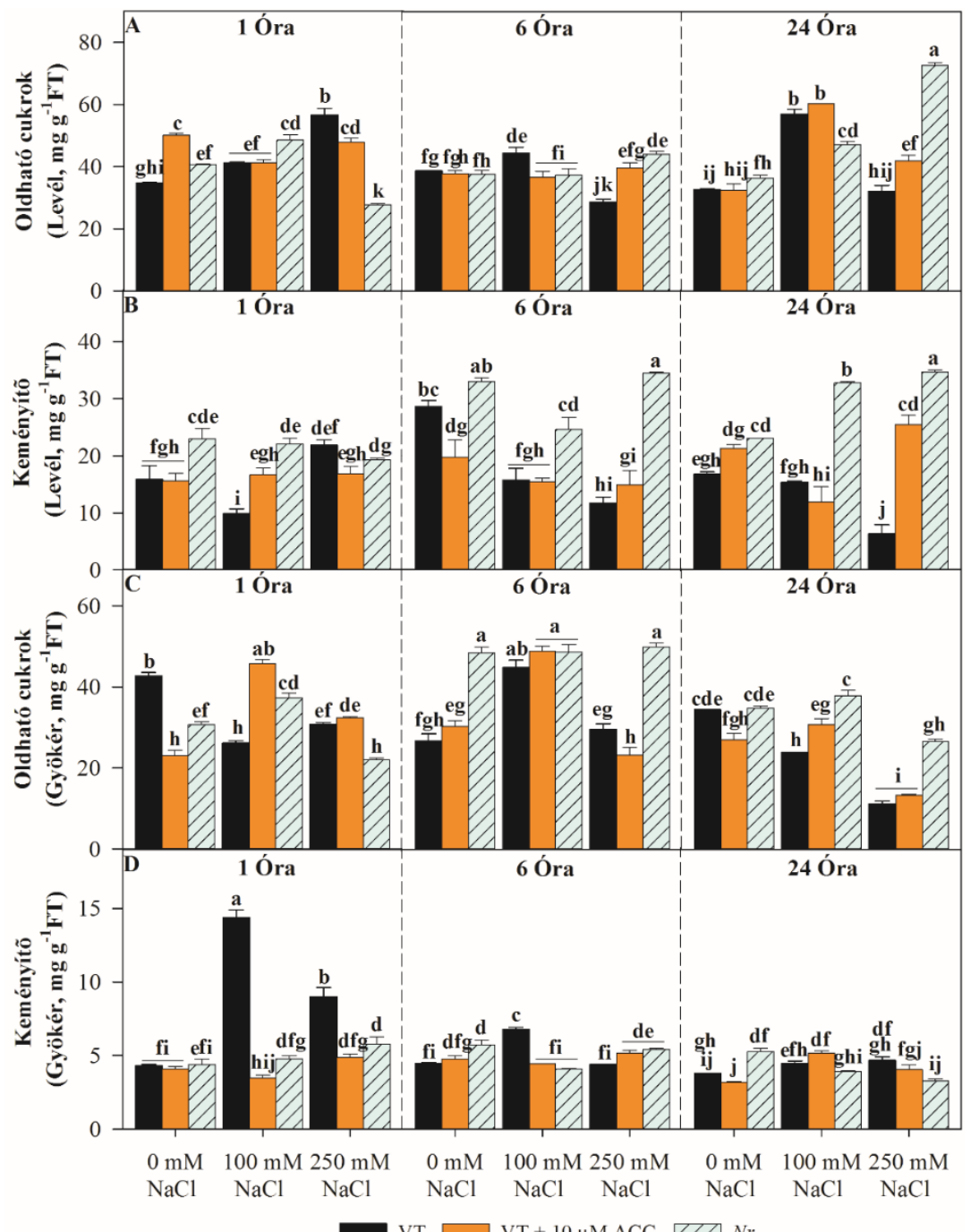

32. ábra A levelek oldható cukor- (A) és keményítő tartalma (B) valamint a gyökerek oldható cukor- (C), illetve keményítő tartalma (D) VT (fekete oszlopok) és $N r$ mutáns (ferdecsíkos, halványkék oszlopok) $(0 \mu \mathrm{M}$ ACC), valamint $10 \mu \mathrm{M}$ ACC-vel kezelt VT (narancssárga oszlopok) paradicsomnövényekben 1, 6, ill. 24 órás $100 \mathrm{mM}$ ill. $250 \mathrm{mM} \mathrm{NaCl}$ expozíciót követően. A kísérlet kezdő időpontja a VT növények ACC kezelése 1. órájától számítva. Átlag + SE, $\mathrm{n}=3$. „FT” = friss tömeg. A különböző betűvel jelölt értékek szignifikáns különbségeket mutatnak a kezelések és az eltérő időpontok között $\mathrm{P} \leq 0,05$ szinten (SNK teszt).

A $N r$ mutánsok a fotoperiódus korai óráiban szignifikánsan erősebb $\mathrm{Y}(\mathrm{CEF}) / \mathrm{Y}(\mathrm{II})$ szinteket mutattak (31. ábra, D). A szóban forgó paraméter a stresszhatás erősödésével egyenes arányú aktiválódást produkált a $\mathrm{Nr}$ mutánsokban, ami a szubletális $\mathrm{NaCl}$ koncentráció alkalmazása esetén az időben hamarabb jelentkezett. Érdekes módon, a VT növények esetében 
csupán a letális só sokk 24 órás mintavételi időpontjában figyeltünk meg szignifikáns $\mathrm{Y}(\mathrm{CEF}) / \mathrm{Y}(\mathrm{II})$ indukciót, amit ráadásul az ACC kezelés kioltott.

A fotoszintézis termékei, az oldható cukrok és a keményítő, ami a fényszakaszban átmenetileg szolgál a redukált szénváz raktárjaként a kloroplasztiszban, köztudottan napi ritmus szerint akkumulálódnak a levelekben. A gyökerekbe irányuló szénhidrát transzportot sok egyéb tényező mellett meghatározza a rendelkezésre álló asszimilátumok mennyisége is. A VT gyökerek oldható cukor-tartalmában kezdetben sóindukált csökkenést, majd a 6. órában, a 100 mM-os kezelés esetében emelkedést, majd ismét csökkenést tapasztaltunk (32. ábra, C).

Érdekes módon, a fényperiódus korai óráiban az exogén ACC kezelés szignifikáns redukciót okozott a gyökerek oldható cukor tartalmában, azonban a szubletális sókoncentráció okozta csökkenéseket az ACC kezelés megakadályozta, míg letális stressz során általában nem befolyásolta (32. ábra, C). A $N r$ gyökerek a fényperiódus elején (1. órás mintavétel) és közepén jellegzetes oldható cukor akkumulálódási mintázatot mutattak, ami a fényszakasz közepe táján, 6 óránál mutatott maximumot. Érdekes módon, a mutáns gyökerek esetében az oldható cukortartalomban bekövetkező változások só-függése kevésbé volt kifejezett. A 6. és 24. órában a hasonlóan kezelt VT értékekhez képest jelentős emelkedést mutattak a $\mathrm{Nr}$ gyökerekben letális sóstressz során, illetve a $100 \mathrm{mM}$-os $\mathrm{NaCl}$ kezelés 24. óráját követően.

A VT levelekben sókoncentráció-függő oldható cukor akkumulációt figyeltünk meg, ami a $250 \mathrm{mM}$-os kezelés 1. óráját, illetve a $100 \mathrm{mM}$-os $\mathrm{NaCl}$ hozzáadásának 24. óráját követően bizonyult a legkifejezettebnek (32. ábra, A). Az exogén ACC az 1. órás mintavételi időponton növelte a VT levelek oldható cukortartalmát, azonban később, illetve szubletális sókoncentráció jelenlétében nem befolyásolta azt. Ezzel szemben, $250 \mathrm{mM} \mathrm{NaCl}$-al kombinálva, az ACC kezdetben kissé visszafogta a só-sokk által indukált oldható cukor felhalmozódást, majd 6 és 24 órás inkubáció után növelte a VT levelekhez képest.

A $N r$ levelekben a fényperiódus korai óráiban magasabb oldható cukor tartalmakat figyeltünk meg, mint a VT kontrollban, melyet a 100 mM-os NaCl koncentráció tovább emelt, bár a 24. órában az ugyanilyen kezelésben részesült VT növényekhez képest mérsékeltebb oldható cukor felhalmozódást figyeltünk meg esetükben (32. ábra, A). A Nr mutánsok, csakúgy, mint az ACC kezelt VT növények, nem akkumuláltak több oldható cukrot a $100 \mathrm{mM}$ NaCl-os kezelés 6. órájáig. Érdekes módon, míg a $250 \mathrm{mM} \mathrm{NaCl} 1$ óra elteltével jelentősen csökkentette a $N r$ levelek oldható cukor akkumulációját, addig a sóstressz időbeli kifejlődésével szignifikáns fokozódást tapasztaltunk, ami a 24. órát követően meghaladta a VT értékének kétszeresét

A sóstressz intenzív keményítő akkumulációt okozott a gyökerekben 1 órát követően, érdekes módon a só koncentrációjával fordított arányban (32. ábra, D). Ugyanez a jelenség a 
$N r$ és az ACC kezelt, VT gyökerek esetében nem volt megfigyelhető, bár a mutáns gyökerekben tapasztaltunk enyhébb növekedést a $250 \mathrm{mM-os} \mathrm{só} \mathrm{kezelés} \mathrm{hatására.} \mathrm{Az} \mathrm{idő} \mathrm{előrehaladtával,}$ sófüggő változást (növekedést) a keményítő felhalmozódásban csupán a VT gyökerekben a szubletális stressz 6. órájában, valamint a $N r$ mutáns, illetve az ACC kezelt gyökerekben - az aktuális sókezelést kapott VT növényekhez képest - a letális sóstressz 6. órájában detektáltunk.

Az exogén ACC visszafogta a VT levelek fényperiódusnak megfelelő keményítő akkumulációját a 6. órában (32. ábra, B). A 100 mM-os sókezelés 1. óráját követően a VT levelekben szignifikáns keményítő tartalom csökkenést tapasztaltunk, mely az idő előrehaladtával mindkét sókoncentráció esetében megfigyelhetővé vált. A $100 \mathrm{mM} \mathrm{NaCl}$ okozta kezdeti keményítő tartalom fogyást az ACC kezelés megakadályozta, ahogyan a letális só stressz indukálta csökkenést is a 24. órában. Érdekes módon, megnövekedett keményítő felhalmozódás figyelhető meg a mutáns levelekben már kontroll állapotban is, melyre a 6 . órában a VT-tól eltérően kisebb befolyással bírt a gyökérben kialakult sóstressz, míg a 24. órára a $\mathrm{NaCl}$ koncentrációval egyenesen arányosan nőtt a keményítő tartalom a $\mathrm{Nr}$ levelekben.

\section{Az eredmények értékelése}

\subsubsection{A gyökérkezelésként adott ACC többlet egy koncentrációs küszöbértéket meghaladva indukál szignifikáns ET emissziót, azonban ennek elérése nélkül is fiziológiai válaszokat vált ki.}

A paradicsomgyökéren keresztül adagolt exogén ACC ET-né konvertálódik a hosszútávú kísérletek során. Alacsonyabb, 0,01 és 1,0 $\mu \mathrm{M}$-os ACC koncentrációk enyhébb emelkedést okoztak a gyökerek ET-termelésében, mely általában mérsékelt erősségű stressz során figyelhető meg, míg a $100 \mu \mathrm{M}$-os ACC sokkal erősebb etilén emissziót indukált mindkét növényi részben (levél és gyökér), ami a súlyosabb stresszhatások velejárója. Az általunk kapott tendenciák jó egyezésben vannak a Wang és Arteca [228] által publikáltakkal, akik kb. 2,5 nL $\mathrm{h}^{-1} \mathrm{~g}^{-1}$ ET kibocsájtást detektáltak a levelek, valamint kb. $6,0 \mathrm{~nL} \mathrm{~h}^{-1} \mathrm{~g}^{-1}$ ET produkciót a gyökerek esetében 7 hetes paradicsomnövényeket vizsgálva (S. lycopersicum L. cv. Heinz) kontroll körülmények között. Ezzel szemben az ET-termelődés 10-30 $\mathrm{nL} \mathrm{h}^{-1} \mathrm{~g}^{-1}$ értékre nőtt abiotikus stressz, oxigénhiányos állapot hatására. A szignifikáns fiziológiai hatás dacára az alacsonyabb ACC koncentrációk esetén a levelek ET-produkció változása csekély, ami azt jelezheti, hogy ezekben a szövetekben az ACC az ET-töl függetlenül is hathat [16, 137]. Ugyanakkor; az ezen szövetekben megjelenő, fiziológiailag aktív szintű, lokális ET akkumuláció kialakulása sem elvethető [229, 230]. Bár az exogén ACC hatása a növekedési paraméterekre elhanyagolható mértékü volt, a fokozott $\mathrm{CO}_{2}$ asszimilációval összhangban a 
hajtás száraz biomassza szignifikáns gyarapodását detektáltuk az alacsonyabb ACC koncentrációk esetében 7 napot követően. Az ACC kezelés által fokozott hajtásnövekedésről hasonló eredményeket talált Trujillo-Moya és Gisbert [231] paradicsomban.

A hosszútávú ACC kezelés jelentős hatást gyakorolt a paradicsomgyökerek és a -levelek iontartalmára is. Korábbi tanulmányok kimutatták, hogy az ET kapcsolatban áll mind a $\mathrm{K}^{+}$ deficienciával, mind a $\mathrm{Na}^{+}$toxicitással a $\mathrm{K}^{+} / \mathrm{Na}^{+}$homeosztázis szabályozásán keresztül. Megemelkedett ET produkciót figyeltek meg Arabidopsis-ban $\mathrm{K}^{+}$hiány során, melyet a nagy affinitású $\mathrm{K}^{+}$transzporter, az AtHAK5 megnövekedett expressziója követett ([191]. Ugyanakkor az exogén Ethephon alkalmazása indukálni képes a HAK5 expresszióját teljes tápanyagellátás mellett is, mely arra enged következtetni, hogy az ET transzkripciós szinten szabályozhatja a káliumfelvételt [192]. Az exogén ACC kezelés is szabályozhatja az aktív káliumtranszportot a PM H ${ }^{+}$-ATPáz aktivitásának módosításán keresztül [232]. Sóstressz során, a hiányos ET-érzékeléssel rendelkező ET-receptor mutáns Arabidopsis (etr1-3) sokkal érzékenyebbnek bizonyult a többlet $\mathrm{Na}^{+}$hatásaival szemben, mint a vad típusú társa, mely a mutáns növény fokozott elektrolit-kieresztésében, csökkent $\mathrm{K}^{+} / \mathrm{Na}^{+}$arányában és redukált PM $\mathrm{H}^{+}$-ATPáz aktivitásában nyilvánult meg. Mindemellett, a VT kallusz exogén ACC kezelését követően magasabb $\mathrm{K}^{+} / \mathrm{Na}^{+}$arányt, intenzívebb PM $\mathrm{H}^{+}$-ATPáz müködést, és ennélfogva stimulált sótoleranciát mutatott, amely nem volt megfigyelhető az ET-receptor mutáns kultúrákban [97]. Váratlan módon, a mi rendszerünkben a felsoroltakkal némileg ellentétes eredményeket kaptunk teljes tápanyagellátás mellett, külön indukált sóstressz hiányában. Kísérleteink azt mutatták, hogy az exogén ACC magas koncentrációban serkenti a $\mathrm{Na}^{+}$ akkumulációt és csökkenti a $\mathrm{K}^{+} / \mathrm{Na}^{+}$arányt, mellyel egyfajta gyenge ionikus stresszt generál a paradicsom szövetekben. Természetesen ez a változás a $\mathrm{K}^{+} / \mathrm{Na}^{+}$arányban kisebb mértékủ ahhoz képest, mely értéket 100-200 $\mathrm{mM} \mathrm{NaCl}$ jelenlétében, hidropónikus kultúrában nevelt növényekben figyeltek meg. Mindazonáltal hasonló nagyságrendű változások voltak megfigyelhetőek más kísérletekben, például amikor homokos-agyagban nevelt paradicsomnövényeket alacsonyabb és magasabb $\mathrm{NaCl}$ koncentrációjú oldatokkal öntöztek csöpögtető öntözéssel egészen a gyümölcsérésig [233]. Az általunk tapasztalt kisebb csökkenés a $\mathrm{K}^{+} / \mathrm{Na}^{+}$arányban edződést kiváltó hatású is lehet egy azt követő ozmotikus-/sóstressz akklimatizáció során, ennélfogva az ACC által okozott eustressznek tekinthető.

\subsubsection{Az exogén ACC kezelés fokozta a $\mathrm{H}_{2} \mathrm{O}_{2}$ felhalmozódást, koncentráció-függő módon befolyásolja a NO és a ONOO- akkumulációs mintázatát.}

Korábbi tanulmányok feltárták, hogy az ET-szabályozott válaszok a ROF illetve RNF szintekben bekövetkező változásokkal párosulnak. Jóllehet, valamennyi ilyen reaktív molekula 
fejthet ki toxikus hatást a növényi szövetekre a megfelelő koncentrációkban, azonban a ROF és RNF számos fiziológiai folyamatot szabályozó szignálként is funkcionálhat [324]. A ROF és RNF generálás ellenére a növények képesek voltak tolerálni a magas ACC (ET) koncentrációkat egy hétig, mely következtetés levonható abból, hogy a növekedési paraméterek kisebb száraztömeg-növekedésen kívül nem változtak szignifikánsan a kezelések hatására. A gyökércsúcsokban a ROF különböző fajtáinak akkumulációja monitorozható a járulékos gyökerek $1 \mathrm{~cm}$-es apikális régióján belül. Itt a $\mathrm{O}_{2}{ }^{\bullet-}$ szintben bekövetkező változások nem bizonyultak szignifikánsnak, és a $\mathrm{H}_{2} \mathrm{O}_{2}$-tartalom növekedése csupán a $100 \mu \mathrm{M}$-os ACC koncentráció esetében volt jelentős. Mivel a 7. napra a NO felhalmozódás gátlódott a 0,01 és a 1,0 $\mu \mathrm{M}$-os ACC kezelések esetében, illetve a $100 \mu \mathrm{M}$ ACC hatására sem lépte túl a kontroll tartományt, a gyökércsúcsi sejtek nem voltak kitéve nitrozatív stressznek a kezelési intervallum ezen időpontjában. Ugyanakkor a tartós, $100 \mu \mathrm{M}$-os ACC által indukált $\mathrm{H}_{2} \mathrm{O}_{2}$ akkumuláció részt vehet $\mathrm{a} \mathrm{K}^{+}$homeosztázist szabályozó ET szignalizációban, így a $\mathrm{K}^{+}$felvétel szabályozásában [192] vagy az effluxban szerepet játszó rendszerek aktiválásában [235-237].

$\mathrm{Az}$ alacsonyabb ACC koncentrációk a gyökércsúcsokhoz hasonló hatással voltak levelek $\mathrm{O}_{2}{ }^{*-}$ és $\mathrm{NO}$ akkumulációjára, azonban enyhe, de szignifikáns módon fokozták a $\mathrm{H}_{2} \mathrm{O}_{2}$ mennyiségét. Ugyanakkor a $100 \mu \mathrm{M}$-os ACC koncentráció számottevő $\mathrm{H}_{2} \mathrm{O}_{2}$ termelést serkentő hatása mellett szignifikáns mértékü $\mathrm{O}_{2}{ }^{*}$ és $\mathrm{NO}$ tartalom növekedést, illetve a két molekula reakciójából keletkező $\mathrm{ONOO}^{-}$akkumulációt idézett elő, mely változások a levelekben nitrooxidatív stressz kialakulásához is vezethettek [95].

\subsubsection{A gyökérzónában mutatkozó ACC többlet a koncentráció és az expozíciós idő függvényében serkentheti vagy gátolhatja a fotoszintézist és befolyásolja a két fotokémiai rendszer müködését.}

A szakirodalmi tudásbázist összegezve, az ET fotoszintézisre gyakorolt hatása ellentmondásos. Jóllehet az ET-nek közvetlen szerepet tulajdonítanak a fiatal/nem öregedő levelek fotoszintézisének szabályozásában, a legtöbb esetben a megnövelt ET tartalom gátló vagy semleges módon befolyásolta a fotoszintetikus aktivitást, például a leggyakrabban vizsgált paraméterként a nettó $\mathrm{CO}_{2}$ asszimilációt. Eddig egyetlen növényfaj, a mustár esetében mutatták ki az ET serkentő hatását [46]. Az intakt paradicsomlevelekre permetezett exogén Ethephonból felszabaduló ET extrém epinasztiát és a virágrügyek lehullását okozta, azonban 24 órát követően sem indukált szignifikáns változást a fotoszintetikus $\mathrm{CO}_{2}$ fixációban, a fotorespirációban vagy a transzspirációs rátában. Ugyanakkor, befolyásolta a $\mathrm{CO}_{2}$ asszimilátumok megoszlását a különböző szervek között [238]. 
Számos szerző foglalkozott az exogén forrásból (legtöbbször ET gáz vagy Ethephon permetezés által) megemelt ET-szint fotoszintézisre gyakorolt hatásával [59 63; 66], de a koncentráció és/vagy expozíciós intervallum-függő vizsgálatok aránya meglehetősen alacsony. Annak ellenére, hogy az ACC természetes úton jelen lehet a gyökér környezetében, mennyisége csökkenhet vagy növekedhet a talajoldatban, jelenlegi ismereteink szerint eddig csupán egyetlen tanulmányban használtak gyökérzeten keresztüli ACC adagolást, és vizsgálták a fotoszintézisre gyakorolt befolyását stresszmentes körülmények között, ahol a salátanövények $10 \mu \mathrm{M}$-os ACC kezelése csökkentette $\mathrm{C}_{2}$ asszimilációt és a sztómakonduktanciát [239].

Kísérleteink során idő- és koncentrációfüggő változásokat detektáltunk a paradicsomnövények fotoszintetikus aktivitásában. Kis ACC koncentrációk alkalmazását követően a kifejlett, nem öregedő levelek szignifikánsan magasabb $A_{N}$ értékeket produkáltak 24 óra, illetve a $0,01 \mu \mathrm{M}$-os ACC hatására 48 óra elteltével. Mivel a g $\mathrm{g}_{\mathrm{sw}}$ alakulása a $100 \mu \mathrm{M}$ os ACC kezelés kivételével nem követte szorosan az $A_{N}$ tendenciáját, a kisebb koncentrációk esetében nem-sztomatikus faktorok részvétele is feltételezhető az $A_{N}$ szabályozásában. Bár a levélre permetezett Ethephon a koncentráció növekedésével egyenes arányban növelte a mustár növények $\mathrm{CO}_{2}$ asszimilációját és RuBisCO aktivitását [240], a sztómakonduktanciára és az intercelluláris $\mathrm{CO}_{2}$ koncentrációra is hasonló befolyással bírt, így az általunk tapasztaltakkal ellentétben sokkal inkább a $\mathrm{CO}_{2}$ elérhetőségének javítását, mintsem a rendelkezésre álló $\mathrm{CO}_{2}$ hasznosítási hatásfok növelését okozta az exogén ET donor kezelés.

Kísérleteinkben a magas ET szintek $A_{N}-r e$ gyakorolt negatív hatása fóleg sztómalimitációból fakadhat az első két napon. 3 nappal a kezelés kezdete után azonban a 100 $\mu \mathrm{M}-\mathrm{os}$ ACC a nem-sztomatikus limitáció nagyobb arányú hatását eredményezheti, amit a $\mathrm{C}_{\mathrm{i}} / \mathrm{C}_{\mathrm{a}}$ arány hirtelen emelkedése sugall, ugyanakkor a sztomatikus faktorok visszanyerték fontosságukat az $\mathrm{A}_{\mathrm{N}}$ szabályozásában a kísérlet végére.

Mivel sem az $\mathrm{F}_{\mathrm{V}} / \mathrm{F}_{\mathrm{M}}$, sem az $\mathrm{F}_{0}$ paraméterekben nem tapasztaltunk konstans, szignifikáns csökkenést $\left(\mathrm{Fv} / \mathrm{F}_{\mathrm{M}}\right)$ illetőleg növekedést $\left(\mathrm{F}_{0}\right)$, kijelenthető, hogy az exogén ACC alkalmazása nem okozott irreverzibilis károsodást a PSII reakciócentrumokban.

A $0,01 \mu \mathrm{M}$ ACC kezelés a Y(I) fokozódását indukálta, ami fluktuáló $A_{N}$ értékekkel társult a 3. naptól fogva. A kísérlet végére, ez az esemény a PSI akceptorának számító komponensek koncentrációinak az enyhébb csökkenését vonta maga után, amire a szignifikáns $\mathrm{Y}(\mathrm{ND}) \rightarrow \mathrm{Y}(\mathrm{NA})$ váltás enged következtetni. Meglepő módon, a Y(I) fokozódásával ebben az esetben nem párosult a Y(II) kontrollhoz viszonyított szignifikáns növekedése. Mindemellett, a 0,01 és $1,0 \mu \mathrm{M}$ ACC-vel történt kezelés első 2 napjában a PSI körüli ciklikus elektronáramlás (CEF-PSI) tranziens aktivációját figyeltük meg. A Y(CEF)/Y(II) aránya a közelmúltban 
bevezetett, sokkal kifejezőbb paraméter a CEF-PSI becslésére [213]. Habár némi marginális növekedés a Y(I) értékeiben megfigyelhető 1,0 $\mu \mathrm{M}$ ACC hatására is a 4. naptól, ez sokkal kevésbé hangsúlyos $\mathrm{Y}(\mathrm{ND}) \rightarrow \mathrm{Y}(\mathrm{NA})$ váltással, illetve a $\mathrm{Y}(\mathrm{CEF}) / \mathrm{Y}(\mathrm{II})$ csupán marginális aktiválódásával társul. A fotoprotektív NPQ kialakításában játszott szerepe mellett a CEF extra ATP-t is szolgáltat a $\mathrm{CO}_{2}$ fixációs folyamatoknak, továbbá beállítja az ATP/NADPH arányt, tehát alapvető szereppel rendelkezik az $A_{N}$ fenntartásában stressz során [214].

Habár lényeges visszaesést tapasztaltunk a nem öregedő levelek Y(II) és qL értékeiben $100 \mu \mathrm{M}$ ACC hatására, a Y(I) csupán tranziens csökkenést mutatott. Mivel a Y(NO)-ban pusztán marginális változásokat figyelhettünk meg - melyek valószínűleg a zárt PSII reakciócentrumok növekvő arányának köszönhetőek - elmondható, hogy a PSII károsodása 7 nap után elhanyagolható mértékü és a PSII által befogott extra energia sikeresen disszipálódott hő formájában a szignifikánsan megnövekedett NPQ folyamatok következtében vagy megkötődött az alternatív elektronakceptorok jóvoltából [242]. Az 5. napon a $100 \mu \mathrm{M}$-os ACC kezelés a $\mathrm{Y}(\mathrm{CEF}) / \mathrm{Y}(\mathrm{II})$ számottevő erősödését indukálta, mely ezt a maximum értéket követően csökkenő tendenciát vett fel. A CEF-PSI képes elösegíteni a proton elektrokémiai potenciál grádiens $(\Delta \mathrm{pH})$ létrejöttét a tilakoidmembránokban, és ahogy már említésre került, az NPQ fokozásával megvédi a PSII-t a fotoinhibíciótól [243]. A Y(NPQ) erősen $\Delta$ pH-függő paraméter, ugyanakkor a $\mathrm{Y}(\mathrm{NPQ})$ és a $\mathrm{Y}(\mathrm{CEF}) / \mathrm{Y}(\mathrm{II})$ maximum értékeik elérése után a $\Delta \mathrm{pH}$ függő violaxantin-deepoxidáció és a biztonságos, alternatív NPQ útvonalak önmagukban képtelenek voltak hatékonyan leszabályozni a fotoszintetikus apparátust. Ez a reaktív molekulák növekvő képződéséhez vezetett, melyek kioltása sem zajlott hiánytalanul. A molekuláris oxigén a fotoszintetikus elektrontranszportlánc nagyon fontos akceptora, ami szélsőséges esetekben (pl. a kioltó mechanizmusok elégtelen funkciója mellett) káros mértékü $\mathrm{O}_{2}{ }^{*-}$ akkumulációhoz vezethet. Bizonyos fokú stressz során fellépő szerkezeti ártalmak következményeként a tilakoidmembránok protonpermeabilitása megnőhet, ami a $\Delta \mathrm{pH}$ és az NPQ elvesztéséhez vezethet [53]. Mivel a $100 \mu \mathrm{M}$-os ACC kezelés stimulálta a $\mathrm{O}_{2}{ }^{\bullet-}, \mathrm{a}_{2} \mathrm{O}_{2}$, a NO és az $\mathrm{ONOO}^{-}$felhalmozódást 1 hét után, az így kialakuló nitro-oxidatív stressz elősegítheti a tilakoidmembránok károsodását és a $\Delta \mathrm{pH}$, valamint az NPQ csökkenését. Mindemellett, ezek a reaktív molekulák aktiválhatják az antioxidáns védelmi rendszereket is, ami hozzájárulhat egy abiotikus stresszhatással szembeni védelemhez is.

A cukrok (glükóz, fruktóz, szacharóz) és a cukoralkohol szorbitol mennyisége ACC koncentrációfüggő módon fokozódik a kezelt növényekben a kontrollhoz képest. A vizsgált cukortartalmak maximuma 0,01-1,0 $\mu \mathrm{M}$-os ACC kezelés esetében volt megfigyelhető. Ez jól egybeesik a $\mathrm{CO}_{2}$ fixáció korai aktivitás-fokozódásában tapasztaltakkal és a száraz biomassza 
gyarapodásával. Hasonló tendenciák fedezhetők fel a gyökér cukor-háztartásában egy nagyon fontos kivétellel. A szállított cukorforma, a szacharóz felhalmozódásában visszaesést detektáltunk az 1,0-100 $\mu \mathrm{M}$-os ACC kezelések esetében. Ez azt sugallja, hogy az exogén ACC megváltoztatja a cukrok elérhetőségét és elosztását a növényi szervek között, ami jól összefügg Woodrow és mtsai. [238] etilénnel kapcsolatos megfigyeléseivel. Számos szerző úgy találta, hogy az oldható cukrok, mint a diszacharidok, a raffinóz családba tartozó oligoszacharidok és a fruktánok erősen kapcsolódnak a stressz-indukált ROF akkumulációhoz a növényekben [244]. Az oldható szénhidrátok, mint ozmoprotektánsok bioszintézise az ozmotikus stresszre adott válaszként is indukálódhat, így stabilizálva a sejtek membránjait. Alacsony koncentrációban, a cukrok szubsztrátként is szolgálhatnak a metabolikus enzimeknek, illetve stressz-indukált változásokat közvetítő szignál funkcióval is rendelkezhetnek. Néhány típusuk, mint a fruktóz, a galaktóz és a raffinóz családba tartozó oligoszacharidok, a fruktánok és a cukoralkoholok bizonyított vagy javasolt antioxidáns hatással bírnak [245 246]. Tehát a megnövekedett cukorés szorbitoltartalom képes lehet kivédeni az oxidatív stressz egyes elemeit abiotikus stresszakklimatizáció során.

$\mathrm{Az}$ újabb eredmények azt sugallják, hogy az ACC ET-független módon is befolyásolhatja a növények életfolyamatait [16, 17, 137-139], mely a mi rendszerünkben sem vethető el, különösen az iontranszport és a fotoszintetikus elektronáramlás esetében. Kísérleteink során csupán apró különbségeket detektáltunk a növényi szövetek ET produkciójában alacsony ACC koncentrációk esetében, ezért további vizsgálatok szükségesek, hogy milyen arányban tulajdoníthatjuk az ACC direkt hatásának az általunk tapasztalt változásokat, ezen kutatások azonban nem képezik részét a jelen értekezésnek.

\subsubsection{Az ET receptor mutáns Never ripe paradicsomgyökerek érzékenyebbek a sóstresszre: a gyökércsúcsok már szubletális stressz esetén is mutatják a sejthalál jellegzetes fiziológiai tüneteit}

Magas sótartalom mellett a legnyilvánvalóbb biokémiai válasz a megemelkedett ROF felhalmozódás, így a $N r$ mutáns segítségével némi betekintést nyerhetünk abba, hogy mi a szerepe szövetek ET-érzékenységének a magas sókoncentrációk által indukált oxidatív stressz kialakulásában. Mindemellett szoros kapcsolat áll fenn az ET és más szignál molekulák, mint a ROF és RNF között [80, 247]. A VT gyökerekben a $\mathrm{O}_{2}{ }^{\circ-}$ akkumuláció szoros sókoncentrációfüggést mutatott, és inkább a letális $\mathrm{NaCl}$ kezelésre korlátozódott, míg a $\mathrm{H}_{2} \mathrm{O}_{2}$ felhalmozódás sokkal kifejezettebb volt szubletális sóstressz során. Ezzel szemben, a $N r$ gyökerekben a VT által tolerálható mértékü só-kitettség során bekövetkező, intenzívebb $\mathrm{O}_{2}{ }^{\bullet-}$ felhalmozása és csökkent $\mathrm{H}_{2} \mathrm{O}_{2}$ mennyiség arra enged következtetni, hogy az ET-érzékelés részleges vagy teljes 
hiánya megváltoztatta a ROF akkumulációs mintázatát a járulékos gyökerekben, a $\mathrm{H}_{2} \mathrm{O}_{2}$-ról a $\mathrm{O}_{2}{ }^{*-}$ javára, már szubletális sóstressz során is. Szoros korrelációt találtak a $\mathrm{O}_{2}{ }^{*-}, \mathrm{a}_{2} \mathrm{O}_{2}$ tartalom és a fehérjekarboniláció között bükkmagvak öregedése során [248]. Mivel a $\mathrm{H}_{2} \mathrm{O}_{2}$ bizonyítottan a legfontosabb szignálmolekula, ami aktiválja az oxidatív stressz ellen védelmet nyújtó folyamatokat, hiányában az oxidatív stressz elleni védekezés nem teljes [249]. Mindezek tükrében elmondható, hogy a $N r$ gyökércsúcsokban megfigyelt változások hozzájárultak a mutáns fokozott sóstressz-érzékenységéhez. Ezek a folyamatok eltérhetnek a különböző genetikai háttérrel rendelkező $N r$ mutánsok esetén, hiszen a Micro-Tom (MT) paradicsom háttérbe introgresszált $\mathrm{Nr}$ mutációval bíró gyökerek enyhe $\mathrm{H}_{2} \mathrm{O}_{2}$ tartalom növekedést produkáltak mérsékelt erősségü, hosszabb távú sóstressz során. Mindemellett, a $\mathrm{Nr}$ gyökerek fokozott KAT, APX és glutation reduktáz (EC1.6.4.2) aktivitást mutattak kontroll körülmények között is. Ennek ellenére, ezen enzimek a SOD-dal együtt, a VT (MT) gyökerekhez hasonló mintázattal müködtek az $N r$ mutánsok esetében is sóstressz alatt. Ez felveti lehetőségét a SODon kívüli, egyéb $\mathrm{H}_{2} \mathrm{O}_{2}$ generáló rendszerek jelenlétét a mutánsokban [250]. Így a $\mathrm{Nr}$ mutánsok Micro-Tom háttérben sótoleránsabbnak bizonyultak az általunk vizsgáltaknál.

A ROF és RNF felhalmozódást kordában tartó egyéb mechanizmusok mellett a NO többlet hozzájárulhat olyan ROF formák kioltásához, mint a $\mathrm{O}_{2}{ }^{*}$, ugyanakkor szélsőséges esetben hozzájárulhat a PCD inicializáláshoz is. A különbség a szubletális és a letális sóstressz között a VT gyökerekben az, hogy a sóstresszt túlélő növények a stressz első 24 órájában tartós NO akkumuláció emelkedést mutattak, míg letális stressz esetében a NO szint növekedése csak az első órára korlátozódott. Ez a $N r$ mutáns genotípusban is hasonlóan történt, viszont esetében sokkal kifejezettebb NO produkció volt mérhető a sóstressz 1. órájában. Az utóbbi időben kiderült, hogy a kadmium stressz során fellépő, NO felhalmozódást a plazma membrán NADPH-oxidáz aktiválódása, illetve ezt követően a $\mathrm{O}_{2}{ }^{\bullet-}$ mennyiségének növekedése kíséri [251]. A szimultán $\mathrm{H}_{2} \mathrm{O}_{2}$ akkumuláció hiánya a kísérlet során azt sugallja, hogy inkább a $\mathrm{O}_{2}{ }^{\circ-}$, mint a $\mathrm{H}_{2} \mathrm{O}_{2}$ müködik együtt a NO-dal a PCD indukálásában [252]. Az általunk beállított rendszerben is hasonló változásokat figyeltünk meg a sóstressznek kitett paradicsomgyökerekben. A NO reagálhat a $\mathrm{O}_{2}{ }^{-}$-dal, melyböl ONOO`- keletkezik, aminek akkumulációja a prekurzorok termelődésétől függ. Bár ez a molekula a növényi sejtekre nem olyan erősen toxikus hatású, mint az állatokban [174], felhalmozódása sokkal intenzívebbnek bizonyult a $\mathrm{Nr}$ mutáns gyökércsúcsokban letális sóstressz során, jóllehet a VT növények esetében is tapasztaltunk marginális növekedést.

Az ET tehát szabályozhatja a PCD szignalizációt a VT növényekben [3]. Az ETindukált kromatinfragmentáció és DNS-létrázódás megfigyelhető számos növényfajban és 
növényi szervben [253], ahogyan mindkét genotípusban letális, illetve a $\mathrm{Nr}$ mutáns gyökerekben szubletális sóstressz során is. Azonban, míg letális stressz során a VT gyökerekben a DNS kontrollált, oligoszómális egységekbe történő fragmentációja (DNS létrázódás), addig a $N r$ mutánsok esetében általános DNS károsodás volt megfigyelhető.

Egyre több bizonyíték sugallja, hogy a magas $\mathrm{H}_{2} \mathrm{O}_{2}$ felhalmozódással asszociált PCD szabályozásában kaszpáz-szerü aktivitással rendelkező cisztein proteázok vesznek részt [247, 254]. Az osztály specifikus, irreverzibilis cisztein proteáz inhibitor, az E-64 segítségével a cisztein proteázok $\mathrm{NaCl}$ koncentrációfüggő módon növekvő képviseletét tapasztaltuk az összproteáz aktivitásban, mely bár nem szignifikánsan, de nagyobb arányú volt a $\mathrm{Nr}$ gyökerekben. Az ET szabályozza a különböző cisztein proteáz gének expresszióját számos növényi szövetben, mint például a csicseriborsó csírázása [255], illetve a szegfüszeg szirmainak szeneszcenciája során [256]. A proteáz aktivitás hasonló mértékben növekedett mindkét genotípusban az emelkedő sókoncentráció függvényében, azonban a $\mathrm{Nr}$ gyökércsúcsokban ez mindenütt kissé erőteljesebb volt az általunk vizsgált körülmények között sóstressz alatt. Mivel bizonyos cisztein proteázok génjeinek indukciója megfigyelhető az etilén-inszenzitív, mutáns etrl-1 ET receptort expresszáló, transzgenikus petúnia pártákban is [257], feltételezhető, hogy vannak specifikus cisztein proteázok, amelyek az ET szignalizáció hiányában is indukálódnak a $N r$ gyökerekben. Ugyanakkor, a proteázok az ET mellett a NO által is aktiválódhatnak. A Cdindukált PCD során akkumulálódó NO fokozta a MPK 6-függő kaszpáz3-szerű aktivitást, ami a PCD végrehajtását eredményezte A. thaliana csíranövényekben [258].

A magas szalinitás okozta ionikus stressz mértékét erősen befolyásolja az ionegyensúlyhiány, főleg a $\mathrm{K}^{+} / \mathrm{Na}^{+}$arány a szövetekben. $\mathrm{A} \mathrm{Na}^{+}$felvétele a citoszolba $\mathrm{K}^{+}$hiánnyal társul [259]. Monteiro és munkatársai [250] megfigyeléseivel szemben - akik nem tapasztaltak szignifikáns $\mathrm{Na}^{+}$akkumulációt az MT háttérü $N r$ mutánsok gyökér, illetve levél szöveteiben mérsékelt, hosszú távú sóstressz során - megnövekedett $\mathrm{Na}^{+}$felhalmozódást tapasztaltunk a VT és a $\mathrm{Nr}$ gyökerekben is mindkét $\mathrm{NaCl}$ koncentráció-hatására. A VT gyökerekkel ellentétben, a $N r$ mutáns sejtekben nagyobb arányú $\mathrm{K}^{+}$felvétel gátlást, vagy $\mathrm{K}^{+}$kiáramlást detektáltunk szubletális sóstressz során, ami szignifikáns mértékü $\mathrm{K}^{+} / \mathrm{Na}^{+}$arány romlást okozott e szövetekben. A $\mathrm{K}^{+}$hiány befolyásolhatja a PCD iniciációját számos PCD-asszociált enzim aktiválásával, mint például a cisztein proteázok [185]. Az állati antiapoptotikus fehérje, a BCL2 túl-expresszáltatása csökkentette a $\mathrm{K}^{+}$kiáramlást és represszálta a vakuoláris processzáló enzim - egy kaszpáz-szerü cisztein proteáz - kifejeződését, enyhítve a PCD-t rizsben [259]. 


\subsubsection{Az exogén ACC előkezelés eltérő módon befolyásolja a levél és a gyökér ET produkcióját sóstressz során, a levelek ET státusza szabályozza a vízháztartást és a klorofillok lebomlását szupraoptimális sókoncentrációkon}

A tolerálható és letális sóstressz eltérő mértékủ ET produkciót indukált a gyökerekben és a levelekben, amelynek időbeli lefolyása is különbözött. A VT gyökerekben a sóstressz csak minimális ET produkció emelkedést váltott ki (100 mM NaCl, 6 óra). Érdekes módon, a letális sókoncentráció esetében nem detektáltunk szignifikáns ET produkció növekedést a VT gyökerekben, sőt, a magas koncentrációjú $\mathrm{NaCl}$ kezelés az idő előrehaladtával egyenesen gátolta az ET emissziót. Ezek a változások jó összefüggésben vannak a korábbi megfigyeléseinkkel, ahol egy másik paradicsomfajta - S. lycopersicum cv. Rio Fuego gyökércsúcsi szegmenseiben is kimutattuk, hogy a szubletális sóstressz növeli, míg a letális sókoncentráció nagyon alacsony szintre csökkenti az ET produkciót [98].

A tolerálható mértékü, $100 \mathrm{mM}$-os és a PCD-t indukáló, $250 \mathrm{mM}$-os NaCl kezelés hatására a $N r$ mutáns gyökereinek esetében az ET kibocsájtás fokozódása jóval hamarabb, már az első órában jelentkezett és tartósabbnak bizonyult, mint VT növényekben. Lanahan és munkatársai [28] szintén kimutatták, hogy az ET bioszintézis nem gátolt a $\mathrm{Nr}$ növényekben. A gyökérben, az exogén ACC kezelés sem váltott ki olyan mértékü ET emissziót $100 \mathrm{mM} \mathrm{NaCl}$ jelenlétében, mint amit a $N r$ mutánsok esetében tapasztaltunk az 1 órás mintavételi időpontban, de az ACC-indukált ET alacsony sókoncentráción végig mérhető volt, míg 250 mM NaCl-nál nem különbözött szignifikánsan a kezeletlen kontrolltól. A megfigyelt változások arra utalnak, hogy intakt ET jelátvitel - benne funkcionális $\mathrm{Nr}$ receptorral - szükséges a szubletális sóstressz során tapasztaltható ET produkció kialakításához, melyben fontos szereplö lehet a hiánytalan, ET-függő, negatív visszacsatolási kör megléte [11], illetve az ACC elérhetősége is.

Az idő előrehaladtával az ET jelátvitel sérülése - legalábbis a $N r$ receptor funkciójának szerepe - és az ACC elérhetősége sincs szignifikáns behatással a $250 \mathrm{mM} \mathrm{NaCl}$ által okozott ET emisszió gátlásra a gyökérben, ami az ET bioszintézist meghatározó egyéb faktorok (pl. a nagy $\mathrm{Na}^{+}$ion koncentráció) felerősödését feltételezi. Paradicsom sejtszuszpenzióban a $250 \mathrm{mM}$ $\mathrm{NaCl}$ által kiváltott ET produkciót sem lehetett fokozni exogén ACC hozzáadásával [188].

A gyökerekkel szemben mindkét sókoncentráció tápoldatbéli jelenléte már 1 óra elteltével intenzív ET emissziót váltott ki a VT levelekben, mely az idő elörehaladtával lecsengett, ugyanakkor a letális mennyiségü $\mathrm{NaCl}$ esetében a 24. órában megjelenő, újabb ET csúcs kapcsolatban állhat a levél szeneszcenciájának só indukálta beindításával [190, 260]. A gyökéren keresztül adagolt ACC $(10 \mu \mathrm{M})$ már 1,5 órát követően a hajtásba jutott és ET produkciót váltott ki napraforgó csíranövényekben [119]. Ugyanakkor, paradicsom $100 \mathrm{mM}$ - 
os NaCl-dal történő kezelése során csupán 15 napon túl figyeltek meg emelkedést a xilém szabad ACC koncentrációjában [261]. Kísérleteink során csupán a 6. órában detektáltunk szignifikáns ET emissziót az ACC kezelés hatására a VT levelekben. Ez összhangban lehet azzal a megfigyeléssel, hogy napraforgó növények ${ }^{14} \mathrm{C}$-ACC kezelése során a levélbe jutó radioaktív ACC mennyiségének a 2/3-a gyorsan ${ }^{14} \mathrm{C}-\mathrm{MACC}$-vé konvertálódott [119].

A gyökér környezetében jelenlévő ACC többlet szignifikánsan csökkentette a levélből felszabaduló ET mennyiségét a szubletális sókoncentrációval kombinálva, míg a $250 \mathrm{mM}$-os sókezeléssel kombinálva ellentétes hatást váltott ki az 1 órás mintavételi időpontban. 24 órát követően azonban, ezek a változások ellenkezőjükre fordultak. Az exogén ACC kezelés és a letális sóstressz együttesen mérsékelik az ET produkciót 24 órát követően, azonban ebben az esetben az ET bioszintézis szabályozása a résztvevő enzimeken kívül is megtörténhet.

A $N r$ mutáció kezdetben jelentősen csökkentette az ET-termelést sóstressz során a VThez viszonyítva, majd a sóstressz erősségével egyenes arányban fokozta 24 órát követően, ellentétben a VT levelekkel. Mindez azt mutatja, hogy a levél ET-termelésének meröben más az ET visszacsatolás általi szabályozottsága a kétféle erősségü sóstressz hatásának időbeni kinetikáját tekintve, mint a gyökér esetében, 24 órán belül. A rövidtávú $N r$ hatáshoz hasonlóan dohány levélkorongok nagy koncentrációjú $\mathrm{H}_{2} \mathrm{O}_{2}$ kezelése során az ET bioszintézis mutánsokban csökkent a stressz okozta, 2. ET csúcs és a sejthalál mértéke is csökkent [190].

Bár a növekedésgátlás, a friss- és száraztömeg-akkumuláció csökkenése a sóstressz legalapvetőbb hatásai közé tartoznak [154], azonban 24 órán belül a biomassza paraméterekben nem figyeltünk meg jelentős változást, jóllehet, az ebben az időpontban végbemenő folyamatok vezethetnek később az említett növekedésgátló hatások kialakulásához.

Ahogy várható volt, a vízpotenciál csökkent a VT levelekben sóstressz során a levélben, azonban ez a hatás szinte eltünt az ACC kezelések hatására. A Nr mutánsok sokkal érzékenyebbek voltak a sóstresszre, mivel a $\Psi_{\mathrm{w}}$ és az RVT értékeik jelentősen csökkentek, különösen 250 mM-os NaCl kezelés hatására, ami azt jelezheti, hogy az ET-érzékelés szükséges a levélszövetek víztartalmának jobb megőrzéséhez magas sókoncentráció mellett. Korábban már sóstressz mentes állapotban kimutatták, hogy a paradicsomnövények ET-érzékenysége befolyásolja a vízháztartás egyensúlyát [135].

Mivel az exogén ACC kezelés kifejezetten növelte a növények vízpotenciálját, míg az ET jelátvitel hiánya csökkentette azt sóstressz alatt, a többlet ET jótékony hatású a sóstressz ozmotikus komponensével szemben. Más a helyzet az ionikus stresszel kapcsolatban. Az optimális $\mathrm{K}^{+} / \mathrm{Na}^{+}$arány megőrzése sóstressz során alapvető fontosságú [150], amelynek csökkenése ionikus stresszt vált ki. A 100 mM-os $\mathrm{NaCl}$ kezelés, 24 óra elteltével enyhébb 
ionikus stresszt okoz a levelekben, míg a letális sókoncentráció sokkal jelentősebbet. A sóstressz ugyanis $\mathrm{NaCl}$ koncentrációtól függően csökkentette a $\mathrm{K}^{+}$és növelte a $\mathrm{Na}^{+}$tartalmakat. A gyökerek esetében a $\mathrm{K}^{+} / \mathrm{Na}^{+}$arány esésért a $\mathrm{K}^{+}$tartalom csökkenése, míg a levelekben inkább a $\mathrm{Na}^{+}$tartalom növekedése volt felelős.

A gyökerek $\mathrm{Na}^{+}$akkumulációs kapacitása 24 óra múltán $100 \mathrm{mM} \mathrm{NaCl}$ jelenlétében telítődött, ugyanakkor a kifejlett, nem öregedő levelek felé történő $\mathrm{Na}^{+}$transzport $250 \mathrm{mM}$ $\mathrm{NaCl}$ kezelés esetében a szubletális sóstresszhez viszonyítva drasztikus mértékben megemelkedett. A $N r$ mutáció a gyökér mellett a levélben is szabályozza a $\mathrm{K}^{+}$tartalom megtartását a szubletális sóstressz 24. órájában, ezért e levelek komolyabb ionikus stresszben részesültek, mint a VT társaik. A letális sókoncentráció jelenlétében a $N r$ mutáció tovább csökkenti a $\mathrm{K}^{+} / \mathrm{Na}^{+}$arányt, azonban a különbség nem szignifikáns a sókezelt VT gyökérhez képest. Az ACC kezelés szignifikánsan nem befolyásolta a gyökerek $\mathrm{K}^{+}$tartalmát a 24 órás sóstressz során, viszont fokozta a $\mathrm{Na}^{+}$transzportját a levélbe $100 \mathrm{mM}$-os $\mathrm{NaCl}$ jelenlétében, továbbá letális sóstressznél a $\mathrm{K}^{+} / \mathrm{Na}^{+}$arány csökkenése is megfigyelhető volt.

A Nr mutánshoz hasonlóan, az exogén ACC kezelés hatását is vizsgáltuk a gyökércsúcsi sejtek életképességére. A szubletális sókezelés 24. óráját követően, az exogén ACC kezelés is okoz életképesség romlást a VT gyökércsúcsokban, míg a $250 \mathrm{mM} \mathrm{NaCl}$ jelenlétében már 1 órát követően csökkentette a gyökércsúcsi sejtek életképességét. Ezek alapján elmondható, hogy a sóstresszel kapcsolódó túlzott ET produkció a stressz mértékétől függően fejtheti ki káros hatásait. A gyökércsúcsok életképességének jelentős csökkenése azonban nem feltétlen vezet a növény pusztulásához. Egy hosszabb akklimatizációs folyamatban a hajtás alkalmazkodása után lehetőség van új járulékos gyökerek iniciációjára, ami a növényi egyed túlélését jelentheti. Másképp fogalmazva, a sóstressz akklimatizáció sikeressége optimális ET produkciót és funkcionális ET jelátvitelt igényel, ami azonban a gyökér és a levél esetében más folyamatok útján valósul meg.

A levélszeneszcencia egyik velejárója a klorofilltartalmak csökkenése. Bár a magas ET produkciót sokszor a klorofill lebomlás serkentésével párosítják [46], a mi rendszerünkben, a sóstressz korai időszakában egy sokkal árnyaltabb kép rajzolódik ki. Sóstressz során a megfelelően szabályozott ET emisszió 24 órán belül nem okoz klorofillbomlást a letális stressz indukálta, 2. ET csúcs megjelenésével sem, sőt, az exogén ACC kezelés szubletális sóstressz során egyenesen fokozza a klorofill- és karotinoidtartalmakat. Ezzel szemben a $\mathrm{Nr}$ receptor mutáció - még ha a kontroll körülmények között magasabb klorofill $a$ és $b$ tartalmakat is okoz - sóstressz során az ET-érzékelés hiányosságai miatt sokkal hamarabb mutatja a klorofill lebomlást. Mindez jól mutatja az ET időben eltérő befolyását a pigmenttartalmakra. 


\subsubsection{A növények ET státusza szabályozza a ROF és RNF molekulák akkumulációját a sóstressz kialakulása során}

\subsubsection{A gyökér $\mathrm{O}_{2}{ }^{*-}$ tartalmának szabályozása sóstressz során}

A reaktív oxigénformák kialakulása a legtöbb esetben a molekuláris oxigén elektronfelvételével létrejövő $\mathrm{O}_{2}{ }^{*-}$ keletkezésével indul. Maga a $\mathrm{O}_{2}{ }^{*-}$ fontos szerepet játszik a sóstressz akklimatizációban, így a $\mathrm{O}_{2}{ }^{*-}$ keletkezésében és kioltásában résztvevő enzimek ET státusztól függő szabályozása központi jelentőségü az oxidatív stressz kialakulásában.

A sóstressz okozta változások a vizsgált ROF és RNF tartalmakban a $\mathrm{Nr}$ mutáns gyökércsúcsok esetében már bemutatásra kerültek, azonban az exogén ACC által kifejtett hatások elemzésére még nem került sor. A szubletális sókoncentrációval történő kezelés 1. óráját követően az exogén ACC csökkenti a $\mathrm{O}_{2}{ }^{*-}$ akkumulációját, mely az SIRBOHI expresszió só általi indukciójának elmaradásával párosul. A későbbi időpontokban azonban az ACC jelentősen növelte $\mathrm{a}_{2}{ }^{*-}$ akkumulációt a megfelelő sókezelésben részesült, VT növényekhez képest. Ezzel összhangban, az etol knockout mutánsban megfigyelhető magas ET szintek stimulálták a gyökérsztélében lévő parenchima sejtek PM-NADPH oxidázát, mely RbohF függő ROF produkcióhoz vezetett és csökkentette a nettó $\mathrm{Na}^{+}$beáramlást a gyökérbe [146]. Rizs sejtkultúrában is megnőtt az OsRBOHA expressziója a $100 \mathrm{mM} \mathrm{NaCl}$ kezelést követő 1. órában [262]. Arabidopsis növények gyökereiben a PM-ben lokalizálódó NADPH oxidáz, az AtrbohF által megnövelt vaszkuláris $\mathrm{ROF}\left(\mathrm{O}_{2}{ }^{\bullet}\right)$ produkció korlátozta a $\mathrm{Na}^{+}$akkumulációját, így csökkentette a $\mathrm{Na}^{+}$transzportját a gyökérből a hajtásba, ahol így magasabb $\mathrm{K}^{+} / \mathrm{Na}^{+}$arányt és sótoleranciát indukált [167]. Az ET tehát befolyásolja az Rboh-függő $\left(\mathrm{O}_{2}{ }^{\bullet}\right)$ produkciót, így a belőle képződő $\mathrm{H}_{2} \mathrm{O}_{2}$ képződéséért is felel [73, 146]. Az általunk használt, Ailsa Craig paradicsomfajtába introgresszált $N r$ mutáció már stersszmentes körülmények között is növelte az SIRBOH1 gén expresszióját, mely szubletális sóstressz során tovább fokozódott, ellentétben a VT gyökerekkel, ahol csak 1 órát követően tapasztaltunk indukciót.

Korábbi vizsgálatainkban [220] kimutattuk, hogy a ROF metabolizmusában szereplő enzimek aktivitása napszakos (cirkadián vagy diurnális) ritmust mutathat, mely az általunk végzett kísérletek során a növények stresszmentes állapotában is megfigyelhető volt. Annak ellenére, hogy több esetben is kimutatták, az ET hatással van az antioxidáns enzimek aktivitására sóstressz során levélben [168; 263- 265], vagy teljes csíranövényben [266], az ET kapcsolatát a gyökér antioxidáns enzimeivel rövidtávú - 24 órán belüli - sókezelés során eddig még kevés esetben vizsgálták.

Az exogén ACC a stressz erősségétől és az expozíciós időtől függően csökkenti a SOD specifikus aktivitását sóstressz alatt. A vizsgált időpontokban, az SIMnSOD expressziója nem 
minden esetben követi a SOD aktivitás-béli változásokat az ACC kezelés esetében sem. A gyökér SOD specifikus aktivitásában, szubletális sóstressz során megfigyelt változások arra utalnak, hogy az exogén ACC kezelés, illetve az általa megemelt ET produkció 24 óra múltán gátolja a $\mathrm{O}_{2}{ }^{*-} \mathrm{SOD}$ általi lebomlását a gyökérben, mely mellett, a 6. órától fokozott $\mathrm{O}_{2}{ }^{*-}$ akkumuláció volt mérhető a gyökércsúcsokban.

$100 \mathrm{mM} \mathrm{NaCl}$ jelenlétében, a $N r$ gyökércsúcsok korábban már ismeretett, megemelkedett $\mathrm{O}_{2}{ }^{*}$ tartalmának másik okozója - a megemelkedett $\mathrm{SIRBOHI}$ expresszió mellett - a SOD specifikus aktivitásának jelentős só-indukálta csökkenése, mely jól mutatja a $\mathrm{Nr}$ receptor és az ET fontosságát a SOD szabályozásában a sóstressz korai időszakában. Ugyanakkor, a $N r$ mutáns gyökerekben a VT-nál nagyobb fokú mitokondriális SIMnSOD expressziót detektáltunk a sókezelések hatására a 6. órától, ami azonban nem mutatkozott meg az összes SOD aktivitásban. A jelenség okozója lehet, hogy az egyéb, nem az SIMnSOD gén által kódolt izoenzimek expressziója, vagy aktivitása is megváltozhatott, ami csökkenést eredményezett a levélszövetek SOD specifikus aktivitásában [267], tehát 24 órán belül, az SIMnSOD jelentősége kisebb lehet a többi SOD izoenzimhez képest. Ugyanakkor, hosszútávú - 20 napon túli - sóstressz során megfigyelték, hogy a MT paradicsomfajta $N r$ mutánsban enyhén fokozódott egy MnSOD izoenzim aktivitása, azonban ennek hatását a teljes SOD specifikus aktivitásra nem vizsgálták [250].

Mindezen túl, az általunk tapasztalt változások mögött a SOD enzim poszttranszkripcionális módosítása is állhat. Bár a $\mathrm{ONOO}^{-}$tirozin nitráció útján blokkolhatja a SOD számos izoformáját [96], mint például a mitokondriális MnSOD izoenzimet Arabidopsisban [268], $100 \mathrm{mM} \mathrm{NaCl}$ jelenlétében a $\mathrm{Nr}$ mutánsokban nem tapasztaltunk szignifikáns emelkedést a gyökércsúcsok $\mathrm{ONOO}^{-}$akkumulációjában, így ezekben a szövetekben a nitrozatív stressz kialakulása nem valószínű. Mindazonáltal egyéb poszttranszkripcionális modifikációk is gátolhatják a SOD izoenzimek aktivitását, mint például a miRNS-ek mediálta transzlációs gátlás [269].

A gyökércsúcsok $\mathrm{O}_{2}{ }^{*-}$ akkumulációja a letális sókoncentráció és az ACC kezelés kombinációja során felerősödik. Míg a VT és az ACC kezelt gyökerekben is represszálódott az SlRBOH1 gén $250 \mathrm{mM}$-os $\mathrm{NaCl}$ alkalmazása során, a $\mathrm{Nr}$ mutánsokban indukciót tapasztaltunk az összes időpontban. Letális sóstressz során a SOD aktivitás a $N r$ mutánsban és az ACC kezelt, VT gyökerekben is hasonlóan redukálódik a 6. órától a VT-vel összehasonlítva, így az adott időpontokban az abszolút ET emisszió, illetve jelátvitel befolyása kisebbnek látszik. Fontos megjegyezni azt is, hogy az ACC előkezelés miatt, a letális sókezelést már egy módosult ET státuszú gyökér kapta, melynek hosszabb távú hatásai az antioxidáns rendszerekre a későbbi, 
mérsékeltebb ET produkció ellenére sem elhanyagolhatóak, ahogy látható Wi és munkatársai [190] munkájában is a letális stressz által kiváltott antioxidáns válasz és az ET produkció kinetikájának összehasonlítása tekintetében.

A közelmúltban megjelent tudományos eredmények felvetik annak a lehetőségét, hogy az ACC egy ET-től függetlenül is müködő szignálmolekula [16, 137]. Ugyanakkor e szövetekben a fiziológiailag hatásos, lokális ET akkumuláció is lehetséges [229, 230].

Összességében megállapítható, hogy a tolerálható sókoncentrációval szemben a 250 mM-os $\mathrm{NaCl}$ koncentráció jelentős $\mathrm{O}_{2}{ }^{*-}$ akkumulációt eredményez, amit egyaránt fokoz az exogén ACC kezelés és az ET jelátvitel blokkolása a $N r$ mutánsban. Ez az akkumuláció a korai időpontokban a PM-kötött NADPH oxidáz indukciójának, illetve a SOD aktivitás idő függvényében kialakuló gátlásának tudható be a kérdéses mintákban. A megnövekedett $\mathrm{O}_{2}{ }^{*}$ tartalom hozzájárulhat a PCD indukcióhoz a gyökércsúcsokban.

\subsubsection{A gyökér $\mathrm{H}_{2} \mathrm{O}_{2}$ akkumulációjának szabályozása sóstressz során}

A szubletális és letális sóstressz a gyökércsúcsok $\mathrm{H}_{2} \mathrm{O}_{2}$ akkumulációs kinetikájában is alapvetően különbözik, hiszen letális stressz során az első $\mathrm{H}_{2} \mathrm{O}_{2}$ maximum később jelentkezik. Annak ellenére, hogy a kétféle erősségű sóstressz során az ACC megemelkedett $\mathrm{O}_{2}{ }^{*-}$ akkumulációt váltott ki a gyökércsúcsokban a 6. órában, a só-indukálta, $\mathrm{H}_{2} \mathrm{O}_{2}$ felhalmozódást gátolta ebben az időpontban, míg 24 óra elteltével mindkét stressztípus esetében növelte.

Ahogy már említésre került, a $\mathrm{H}_{2} \mathrm{O}_{2}$ az egyik legfontosabb szignálmolekula az oxidatív stressz ellen védelmet nyújtó folyamatok aktiválásában [249]. Nyárfa kallusz sejtekben a sóindukált $\mathrm{H}_{2} \mathrm{O}_{2}$ termelés fokozta a sótoleranciát, a $\mathrm{Na}^{+}$szintek alacsonyan, míg a $\mathrm{K}^{+}$tartalom magasan tartásán keresztül [105]. $\mathrm{A}_{2} \mathrm{O}_{2}$ akkumulációját előidéző folyamatok közül a 6.3.2.1. alfejezetben ismertetett SOD-ot, míg a $\mathrm{H}_{2} \mathrm{O}_{2}$ lebontásában résztvevő enzimek közül a $\mathrm{KAT}$, a POD és az APX szerepét vizsgáltuk. A mi rendszerünkben, szubletális sóstressz során, a KAT aktivitás kis mértékben nőtt csak meg a VT gyökereiben 6 óra elteltével, ami később nem volt megfigyelhető. Ugyanakkor az APX aktivitás az 1. és a 24. órát követően fokozódott. Eltérő sótüréssel rendelkező, tunéziai paradicsomfajták sókezelése gyorsan gátolta a toleráns és az érzékeny fajta gyökereiben a KAT aktivitást, amely az utóbbi esetében később helyreállt, ugyanakkor a közepes sótoleranciával rendelkező fajta gyökereiben csupán enyhe változások voltak megfigyelhetők. Az APX aktivitás az érzékeny fajtában 12 óra múltán lecsökkent, a közepes toleranciával rendelkező esetében nem változott, míg a toleráns növények gyökereiben megemelkedett. A POD aktivitás tendenciája is ehhez hasonlóan alakult [270]. 
A 100 mM-os $\mathrm{NaCl}$ kezelést követő 24. órában, a $\mathrm{Nr}$ és az ACC kezelt gyökerekben viszont a megfigyelt KAT aktivitás nem párosult a gyökércsúcsok $\mathrm{H}_{2} \mathrm{O}_{2}$ tartalmának csökkenésével, ami elmondható a letális koncentrációjú $\mathrm{NaCl}$ kezelés esetében is. Azonban, míg a $N r$ gyökerekben a KAT aktivitás növekedése az SIKAT1 és az SIKAT3 gének expressziós fokozódásával járt, az ACC kezelt gyökerekben mind három vizsgált KAT izoenzim gén represszálódott az említett időpontra.

A $N r$ gyökerekben 1. órát követően a VT-hoz képest csökkent $\mathrm{H}_{2} \mathrm{O}_{2}$ produkciót detektáltunk, melyhez a teljes gyökérben mért SOD aktivitás csökkenése és a KAT-, valamint a POD specifikus aktivitás növekedése is társult. Ebben az időpontban, az említett sókezelésben részesített $N r$ gyökerek SIKAT1 indukciója a VT-nál kisebb mértékü volt, ugyanakkor a mutánsokban elmaradt az SIKAT3 repressziója. A $N r$ mutáció az idő függvényében befolyásolta KAT aktivitást a MT paradicsomfajta gyökereiben hosszútávú sóstressz során is [250].

Szubletális sóstressz során, a KAT specifikus aktivitás növekedését vagy csökkenését az ACC kezelt növényekben a POD aktivitás ellentétes változása követte, mely feltételezi, hogy a két enzim aktivitása komplementálja egymást. Az Ailsa Craig háttérü, $N r$ mutáns gyökerekben gátlódott a POD aktivitás a $100 \mathrm{mM}$-os $\mathrm{NaCl}$ kezelést követő 6. és 24. órában, mely jó összefüggésben van a hosszútávú sóstressz során, MT háttérben tapasztaltakkal [250].

A 6 órás mintavételi időpontban, az exogén ACC és a tolerálható mennyiségű $\mathrm{NaCl}$ jelenlétében tapasztalt $\mathrm{H}_{2} \mathrm{O}_{2}$ tartalom csökkenés a gyökércsúcsokban a gyökér APX specifikus aktivitásának növekedésével párosult, mellyel együtt fokozódott az SlAPX2 expressziója is.

A $N r$ mutáció a sókezelések korai óráiban van leginkább hatással az APX specifikus aktivitásra a gyökerekben, mely az ACC- és sókezelt VT növényekben is megfigyelhető, illetve hatásuk mibenléte stressz erősség- és időfüggő. A tolerálható mértékü $\mathrm{NaCl}$ kezelés 6. órájában, a $N r$ mutánsban jelentősen csökkent az APX aktivitás, ugyanakkor az SlAPX1 és SlAPX2 izoenzimek expressziója erősen indukálódott. Az exogén NO képes befolyásolni a mitokondriális APX aktivitást, NO és aszkorbát koncentrációfüggő módon [271]. Az APX aktivitás ET jelátvitel általi, időfüggő szabályozása hosszútávú sóstressz során is megmutatkozott MT háttérü, $N r$ mutáns gyökerekben [250].

Hat óra elteltével a letális sókoncentráció és az ACC jelenlétében megfigyelt $\mathrm{H}_{2} \mathrm{O}_{2}$ tartalom változáshoz a gyökér csökkent SOD aktivitása is hozzájárulhatott. Az ACC jelenlétében történő, $250 \mathrm{mM}$-os $\mathrm{NaCl}$ kezelés esetében is elmondható, hogy - az 1. mintavételi időpontot kivéve - a POD a KAT specifikus aktivitás változásával fordított irányban módosult a gyökérben. Az exogén ACC megakadályozta a gyökér SlKAT2 és SlKAT3 izoenzimek 250 mM-os $\mathrm{NaCl}$ okozta represszióját az 1. órában, fokozta az SlKAT3 gén kifejeződését és 
enyhítette a többi vizsgálat $K A T$ gén expressziós gátlását is a későbbi időpontokban. Ez megemelkedett KAT aktivitást eredményezett, mely 6 óra elteltével a gyökércsúcsok $\mathrm{H}_{2} \mathrm{O}_{2}$ tartalmának csökkenésével is kapcsolatba hozható. Fontos megjegyezni, hogy mindez annak ellenére történt, hogy nem detektáltunk szignifikáns ET emisszió növekedést az ACC kezelt gyökerekben letális stressz során.

$250 \mathrm{mM} \mathrm{NaCl}$ a VT paradicsomgyökerekben fokozta a POD aktivitást, melyet az 1. és 24. órában gátolt a $N r$ mutáció. Hasonlót figyeltek meg ein3eill mutáns lúdfüben is [266].

250 mM-os $\mathrm{NaCl}$ jelenlétében a $\mathrm{Nr}$ növények APX aktivitása szignifikánsan nőtt, ellentétben a szubletális sóstressz esetében megfigyeltekkel. Ezen túlmenően a citoszolikus SlAPX1 és SlAPX2 gének is erős expressziós aktiválódást mutattak. Az enzim citoszolikus vagy peroxiszomális izoformáinak túlexpresszáltatása növelheti a sótoleranciát [272]. Bár az APX aktivitása megnőtt VT paradicsomban hosszútávú sóstressz során, a SOD által fokozott $\mathrm{H}_{2} \mathrm{O}_{2}$ szintek kordában tartásához csupán kis mértékben járult hozzá [168].

A stressz mértékével egyenes arányban a ROF akkumuláció toxikussá is válhat, mely oxidatív stresszhez vezet, így károsodhatnak a makromolekulák és a membránok is [105]. A túlzott ROF produkció $\mathrm{K}^{+}$kiáramláshoz vezethet, főleg a GORK és NSCC csatornákon keresztül, ami inicializálja a PCD-t [156].

A $\mathrm{H}_{2} \mathrm{O}_{2}$ akkumulációja a VT gyökércsúcsokban időben hamarabb következik be a tolerálható sókoncentrációnál, mint a $250 \mathrm{mM} \mathrm{NaCl}$ kezelés esetén, és a 24. órára mindkét mintában lecseng. A korai $\mathrm{H}_{2} \mathrm{O}_{2}$ akkumuláció lehetővé teszi olyan antioxidáns enzimek korai indukcióját és enzimatikus aktiválódását, mint az APX, míg a letális sókoncentrációnál a $\mathrm{H}_{2} \mathrm{O}_{2}$ lebomlásához a POD és a KAT aktivitás indukciója nagyobb mértékben járul hozzá, ami különösen az ACC kezelt mintákban és az $N r$-ben jelentős. Ezekben a gyökércsúcsokban azonban az antioxidáns enzimek aktiválódásának ellenére a sóstressz hatására a sejtek életképessége visszafordíthatatlanul károsodik.

6.3.2.4. A gyökércsúcsok NO és a ONOO- akkumulációjának exogén ACC okozta változásai eltérö erösségü sókezelések során

A VT gyökércsúcsokban a sókezelés megemelte a NO akkumulációt, ami 100 mM-os $\mathrm{NaCl}$ esetén egy tartós, viszonylag egyenletes emelkedés, míg a letális sóstressznél az 1. órára korlátozódik. A kétféle erősségű sóstressz által kiváltott NO akkumulálódási kinetikára az exogén ACC időben ellentétesen hatott, kis mértékü sóstressznél inkább gátolt, míg $250 \mathrm{mM}$ NaCl-nál 24 óra múlva a sókezelt VT-hez képest jelentősen megemelkedett NO szinteket detektáltunk. Az Nr mutánsokban a NO csak az első órában akkumulálódott nagyobb 
mértékben, mint a megfelelő, sókezelt VT gyökércsúcsokban. A magas NO szinteknek fontos szerepe lehet a védekezésben, hiszen sóstressz során a NO fokozta az antioxidáns enzimek aktivitását $[172,176,177]$, ugyanakkor a túlzott $\mathrm{NO}$ és $\mathrm{O}_{2}{ }^{*-}$ akkumuláció ONOO képződéséhez és az intenzív nitráció miatt nitrooxidatív stressz kialakulásához vezethet a növényekben [76]. Fontos tehát a $\mathrm{O}_{2}{ }^{-} \% \mathrm{ONOO}^{-}$aránya is az adott szövet túlélése szempontjából.

A szubletális sókoncentráció jelenlétében, az ACC kezelés megemelt $\mathrm{O}_{2}{ }^{*}$ és csökkent NO akkumulációt okozott a gyökércsúcsokban. Szubletális sóstressz során, a ONOO- két prekurzorának megemelkedése nem okozott szignifikáns $\mathrm{ONOO}^{-}$akkumulációt egyetlen időpontban sem, míg jelentősen fokozta szintézisét a letális sóstressz korai szakaszában. Bár a $\mathrm{ONOO}^{-}$keletkezése nagyban függ a két prekurzor szimultán képződésétől, a folyamatot a $\mathrm{O}_{2}{ }^{\bullet-}$ produkció szubcelluláris helye felé történő NO diffúzió határozza meg [273]. Az ET és a ONOO` képződés kapcsolatáról sóstressz során nincs sok információnk, és ahogy már említésre került, a $\mathrm{Nr}$ mutáció nem is befolyásolja szignifikánsan az $\mathrm{ONOO}^{-}$akkumulációt járulékos gyökerek apikális régiójában. Érdekes módon, még ha a szubletális sókoncentráció jelenlétében a ONOO- felhalmozódás nem is változott, az ACC kezelés a molekula fokozott képződéséhez kedvezőtlen $\mathrm{NO}$ és $\mathrm{O}_{2}{ }^{\bullet-}$ akkumulációs mintázatot alakított ki [273]. Ezzel szemben a letális sóstressz során a NO tartalmakat az ACC kezelés a ONOO- képződés indukciója útján is csökkenthette. Ezekben a mintákban lehetőség van a nitrooxidatív stressz kialakulására.

A gyökércsúcsokban mind az exogén ACC formájában indukált ET/ACC többlet, mind az ET jelátvitel blokkolása oxidatív, illetve nitrooxidatív stresszt váltott ki letális sóstressz alatt, amelynek hátterében eltérő mechanizmus áll. Bár mindkét esetben megemelkedett a $\mathrm{O}_{2}{ }^{\bullet-}$ és peroxinitrit akkumuláció, ez exogén ACC kezelés mellett erőteljesebb. Míg a $\mathrm{O}_{2}{ }^{\bullet}$ akkumulációt az $N r$-ben elsősorban a SOD gátlás okozza, a $\mathrm{H}_{2} \mathrm{O}_{2}$ elbontásához a mutánsban kisebb mértékben járul hozzá a KAT és rövid távon az APX, mint az ACC kezelt gyökerekben. Letális sóstressznél a gyökércsúcsok ET státuszának változása (exogén $\mathrm{ACC}, \mathrm{Nr}$ ) növeli a sóérzékenységet. Tolerálható sóstressznél azonban az exogén ACC kezelés eleinte jelentősen csökkenti a $\mathrm{O}_{2}{ }^{\bullet-}$ felhalmozódását, viszont nem csökkenti a $\mathrm{H}_{2} \mathrm{O}_{2}$ akkumulációt, ami mérsékeli az oxidatív stresszt, és ami lehetővé teszi olyan antioxidáns enzimek expressziójának indukcióját (SlAPX2) és aktivitásának emelkedését, mint az aszkorbát peroxidáz.

\subsubsection{A levél $\mathrm{O}_{2}^{* *}$ akkumulációjának szabályozása sóstressz során}

Szubletális $\mathrm{NaCl}$ koncentráció alkalmazása során a paradicsom kifejlett, nem öregedö leveleiben a $\mathrm{O}_{2}{ }^{\bullet-}$ mennyiségi változása periodicitást mutat, melyet nem befolyásolt sem a $\mathrm{Nr}$ mutáció, sem az exogén ACC kezelés. A sókezelések hatására azonban az 1 és 24 órás 
időpontokban fokozódott a $\mathrm{O}_{2}{ }^{\bullet-}$ akkumuláció. Brassica juncea rövid időtartamú sókezelése során az alacsonyabb és a magasabb sókoncentrációk is növelték a $\mathrm{O}_{2}{ }^{\bullet-}$ mennyiségét a levelekben 12-, illetve 24 óra elteltével [274], melyet a legtöbb időpontban mi is megfigyeltünk.

A levélben a SOD specifikus aktivitása a gyökérhez képest némileg eltérő kinetikával válaszolt a sókezelésekre. Továbbá, míg a gyökérben nagyobb a szerepe az ET általi SOD szabályozásnak szubletális $\mathrm{NaCl}$ koncentráció jelenlétében (ACC, $\mathrm{Nr}$ mutáns), addig a levélben a vizsgált időpontokban nem, vagy csak néhány esetben fedezhető fel összefüggés.

Ugyanakkor elmondható, hogy a $N r$ mutáció és az ACC kezelés is hatott a SOD izoenzimek expressziójára, viszont nem gyakorolt szignifikáns hatást az össz-SOD aktivitásra.

Ezzel szemben, a szuperoxid szintézisét katalizáló SIRBOHI indukálódik a mutánsban a $100 \mathrm{mM} \mathrm{NaCl}$ hozzáadását követő 1 . óra után, melynek befolyása a $\mathrm{O}_{2}{ }^{\bullet-}$ produkcióra nem tisztázott. Ezen túlmenően, az SIRBOH1 represszálódott a szubletális sókoncentráció hozzáadását követő 6. órában a VT és a $N r$ mutáns levelekben, melyet az ACC kezelés megakadályozott. Ugyanakkor az $N r$ levekben az említett gén kifejeződésében 24 óra elteltével ismét indukciót tapasztaltunk. Ez felveti a növény ET státuszának befolyását a levél $\mathrm{O}_{2}{ }^{\bullet-}$ produkciójára szubletális sóstressz során, a szubcelluláris képződés lokalizációját tekintve.

A $100 \mathrm{mM}$-os $\mathrm{NaCl}$ által indukált kloroplasztikus $\mathrm{SlCu} / \mathrm{ZnSOD}$ expressziót a $\mathrm{Nr}$ mutáció mérsékelte, míg represszálta a szintén kloroplasztikus SlFeSOD kifejeződést 24 órát követően. Az exogén ACC is inkább e két izoenzim expressziójára volt hatással 24 órán belül, ami jelzi az ET szerepét a kloroplasztikus ROF szintek befolyásolásában. A megfigyeléseinkkel összhangban, a MT háttérbe introgresszált $\mathrm{Nr}$ mutáció a hosszútávú, 100 mM-os NaCl kezelés során csökkentette a $\mathrm{Cu} / \mathrm{ZnSOD}$ izoenzimek aktivitását a levelekben a sókezelt, VT növényekhez képest [250]. Ennek megfelelően, brokkoliban az ERF1 gén (BoERF1) túlexpresszáltatása három napos sóstressz után növelte a SOD enzimek aktivitását a csíranövények leveleiben, mely csökkentette a $\mathrm{O}_{2}{ }^{*-}$ akkumulációt, valamint a sejthalál mértékét [275]. Ezen túlmenően a dohány exogén ACC kezelése során is mutattak ki változást a kloroplasztikus SOD izoenzimek expressziójában [276].

$\mathrm{A} \mathrm{O}_{2}{ }^{*}$ akkumulációja a VT-ben kezdetben sokkal jelentősebb volt a letális sóstressz esetében, mint a tolerálható sókoncentrációnál. Érdekes módon a letális só-sokk esetében mind a $N r$ receptor defektusa mind az exogén ACC alkalmazása jelentősen csökkentette a sóindukált $\mathrm{O}_{2}{ }^{*-}$ felhalmozódást, mely ellentétben áll a gyökérben megfigyeltekkel, azonban a háttérben megbúvó folyamatok az idő függvényében változtak.

A SOD aktivitását a letális sóstressz már 1 óránál emelte a VT-ben, azonban a jelentős indukció 24 óránál következett be. Az enzim aktivitására a 6. óráig mind az ACC kezelés, mind 
a ET receptor mutációja serkentőleg hatott a VT-hez képest, ami azonban a 24 órás mintában jelentős gátlásba csap át. Az 1 órás mintavételkor, a $\mathrm{Nr}$ mutáció és az ACC kezelés is fokozta a SlFeSOD kifejeződését a levélben, $250 \mathrm{mM} \mathrm{NaCl}$ jelenlétében, míg a 24 órás időpontban a $N r$ mutáció által gátolt SOD aktivitáshoz az SlFeSOD és a SIMnSOD gének repressziója társult. A 6 órás időpontban, az SIRBOH1 gén is erősen represszálódott a mutánsokban, majd 24 óra után az ACC kezelés mellett is, ami befolyásolhatja a $\mathrm{O}_{2}{ }^{\bullet-}$ mennyiségét.

Hasonlóan saját eredményeinkhez, a sóérzékeny borsólevelek mitokondriális MnSOD expressziója is csökkent a sóstressz során [277]. Ezzel szemben a rizs Cu/ZnSOD túlexpresszáltatása dohány kloroplasztiszokban sótoleranciához vezetett [278]. A rizs citoszolikus SOD izoenzimek expressziója azonban eltérő módon válaszolt a sókezelésre a növények hajtásában [279].

Mindazonáltal fontos következtetés, hogy erős sóstressz során a $\mathrm{Nr}$ mutánsok és az ACC kezelt, VT növények leveleiben, a 6 . órában a $\mathrm{O}_{2}{ }^{\bullet-}$ lebomlása fokozódik, addig a 24. órában az enzimatikus lebontás és ezzel együtt a termelődés mérséklődése figyelhető meg. Mindkét változáshoz az ET-termelésnek a megfelelő sókezelt VT-hez képest mért csökkenése vagy a jelátvitelének zavara társítható, bár a két, különböző csoport $\mathrm{O}_{2}{ }^{*-}$ akkumulációjában részt vevő mechanizmusok hozzájárulása a megfigyelt változásokhoz eltérő lehet [75].

\subsubsection{A levél $\mathrm{H}_{2} \mathrm{O}_{2}$ akkumulációjának szabályozása sóstressz során}

100 mM-os $\mathrm{NaCl}$ jelenlétében a $\mathrm{H}_{2} \mathrm{O}_{2}$ felhalmozódás az 1 órás mintán kívül látszólag kevéssé változott, amit az ACC kezelés nem módosított szignifikánsan a levélben. Ugyanakkor, a $\mathrm{Nr}$ mutáció szerepe a szubletális sóstressz indukálta $\mathrm{H}_{2} \mathrm{O}_{2}$ akkumuláció fokozásában a 24. órában vált szignifikánssá.

A VT növényekben a KAT és a POD aktivitás a kezelés után röviddel megemelkedik, ami a kísérlet végére lecseng, míg az APX aktivitás általában nem változik, csak a 6. órás mintában csökken. Eltérő sótüréssel rendelkező, tunéziai paradicsomfajták sós tápoldattal (150 $\mathrm{mM} \mathrm{NaCl}$ ) történő öntözése során a levelekben - a gyökérrel ellentétben - 6 és 12 órát követően alig változott a KAT aktivitás, mely a toleráns fajtát kivéve - ahol nőtt - az APX aktivitásról is elmondható. A POD aktivitás, bár 6 óránál enyhe maximumot mutatott, nem módosult számottevően 12 órán belül [270]. A levelek KAT és POD aktivitásában szubletális sóstressz során mi is hasonló megfigyeléseket tettünk. Ezen túlmenően, a VT levelekben, a $100 \mathrm{mM}$ $\mathrm{NaCl}$ hozzáadását követő 1 óra elteltével indukálódott az SIKAT1 expresszió, mely a 6. órában represszálódott. Az SIKAT2 és SIKAT3 expressziót nem befolyásolta ez a kezelés. Az általunk használt paradicsomfajtában azonban az APX aktivitás a VT-ben a 6 órás mintavételi 
időpontban erősen lecsökkent, bár a vizsgált, citoszolikus APX gének - SlAPX1 és SlAPX2 nem represszálódtak.

Érdekes módon, 6 órát követően a $100 \mathrm{mM}$-os $\mathrm{NaCl}$ és az ACC kezelés kombinált hatására a KAT specifikus aktivitása - dacára a fokozott SIKAT3 expressziónak - kissé mérséklődött. Viszont az ACC hatására a POD specifikus aktivitása jelentősen megemelkedett, továbbá mérséklődött az APX müködésének sóindukálta csökkenése is. Az utóbbi jelenség a $\mathrm{Nr}$ levelekben is megmutatkozott, viszont esetükben a KAT specifikus aktivitása fokozódott a megfelelő sókezelésben részesített, VT levelekhez viszonyítva, mely az SIKAT1 represszió elmaradásával hozható kapcsolatba.

A $100 \mathrm{mM}$-os $\mathrm{NaCl}$ kezelés 24. óráját követően, a $\mathrm{Nr}$ mutáció által fokozott $\mathrm{H}_{2} \mathrm{O}_{2}$ akkumulációban szerepet játszhat a KAT és az APX aktivitás csökkenése, valamint a SOD specifikus aktivitásának enyhe fokozódása. A jelenséget az SlKAT1 erős repressziója kísérte, mely felveti az izoenzim kiemelt szerepét a folyamatban, mivel az SIKAT2 expresszió szimultán fokozódása sem enyhítette az aktivitás csökkenését. Ugyanakkor ez nem zárja ki a gátló természetü poszttranszlációs módosítások szerepét a folyamatban.

Egy kisebb 6 órás emelkedést követően 24 óra elteltével az ACC és az $N r$ mutáció is gátolta az APX specifikus aktivitását. Ugyanitt a $100 \mathrm{mM} \mathrm{NaCl}$ represszálta az SIAPX1 és -2 géneket a levélben, ami felelhet az Nr mutánsokban és az ACC-kezelt levelekben megfigyelt APX specifikus aktivitás csökkenésért. A $N r$ mutáció által erőteljesen gátolt APX aktivitás a $100 \mathrm{mM} \mathrm{NaCl}$ kezelés 24. óráját követően (a KAT aktivitás csökkenésével párhuzamosan) a $\mathrm{H}_{2} \mathrm{O}_{2}$ akkumuláció jelentős növekedésével járt a 24 órás időpont esetében. A $N r$ mutáns MT paradicsomlevelekben, $100 \mathrm{mM}$-os $\mathrm{NaCl}$ alkalmazásakor is csökkenést figyeltek meg a levél APX aktivitásában a 20. és a 36. napon [250].

A kísérleteink során vizsgált időpontokban, $100 \mathrm{mM} \mathrm{NaCl}$ jelenlétében, a levél POD aktivitását enyhén növelte a $N r$ mutáció, mely az 1 . és a 24 . órában bizonyult szignifikánsnak. Más esetben, a MT paradicsomfajta $N r$ mutáns genotípusában nem figyeltek meg változást a KAT specifikus aktivitásban hosszú távú, $100 \mathrm{mM} \mathrm{NaCl}$ kezelés során a VT levélhez képest, ugyanakkor a $\mathrm{Nr}$ mutáció fokozta a POD specifikus reakciót a 7. napon, amit később, a 20. és 36. napokon csökkentett [250].

A $250 \mathrm{mM}$-os $\mathrm{NaCl}$ tápoldatbéli jelenléte által indukált intenzív $\mathrm{H}_{2} \mathrm{O}_{2}$ felhalmozódást a kísérlet 1. órájában a $N r$ receptor mutációja vagy az exogén ACC kezelés első ránézésre kismértékben befolyásolta a levelekben. A későbbiekben mind az exogén ACC kezelés, mind az ET receptor mutációja jelentősen megemelte a $\mathrm{H}_{2} \mathrm{O}_{2}$ akkumulációt a VT kontrollhoz viszonyítva, ami az $\mathrm{Nr}$ mutánsokban a 24. óráig megmaradt. 
Ugyanakkor az exogén ACC által fokozott ET produkció a letális sókezelés 1. óráját követően indukálta a KAT aktivitást, mely az APX müködésének csökkenésével társult. A megfigyeltekben az SIAPXI és -2 expressziója valószínüleg kisebb szerepet játszott. Az SIKAT1 expressziót rövid idő alatt, önmagában is fokozta az exogén ACC, mely a letális sókoncentráció hozzáadását 1 órával követően is látható volt, azonban ez nem különbözött a megfelelő sókezelést kapott VT levelektől.

Megfigyeléseink alapján elmondható, hogy a hirtelen megemelkedő ET produkció a vad típusú ET receptoron keresztül indukálta az SIKAT1 izoenzim expresszióját a levélben az 1 órás mintavételkor. Az izoenzim kifejeződését később is befolyásolja a $N r$ mutáció és az ACC kezelés is, időfüggő módon.

A $N r$ levélben gátlódott az APX specifikus aktivitás a korai időpontokban, a megfelelő sókezelés során, viszont fokozódott a POD müködés. A POD izoenzimek eltérő arányú expressziót mutattak kukorica hosszútávú sóstressze során [280]. Korábban megfigyelték, hogy a citoszolikus APX dupla mutánsok leveleiben az enzim hiányát egyéb antioxidáns enzimek kompenzálták [281], amire jó jelölt a POD.

A letális sókoncentráció jelenlétében, a $N r$ mutáns és az ACC kezelt paradicsomnövények leveleiben 6 óra elteltével megfigyelt erőteljes $\mathrm{H}_{2} \mathrm{O}_{2}$ akkumulációban kiemelt szerep jutott a fokozott SOD aktivitásnak. Bár mindkét csoportban megemelkedett a KAT és a POD - az ACC kezelt növényekben az APX is - specifikus aktivitása, a $\mathrm{H}_{2} \mathrm{O}_{2}$ felhalmozódást nem voltak képesek jelentősen mérsékelni. Az itt megfigyelt KAT aktivitás változásokhoz az SIKAT1 és SIKAT3 expresszió fokozódás társult. Tehát ez esetben a $\mathrm{H}_{2} \mathrm{O}_{2}$ képződésének mértéke túlnőtte az antioxidáns rendszerek kapacitását.

A letális $\mathrm{NaCl}$ kezelést követő 24. órában az exogén ACC jelenléte mérsékelte a SOD és a POD, viszont erősen indukálta az APX specifikus aktivitást, mely visszafogta a sóstressz indukálta $\mathrm{H}_{2} \mathrm{O}_{2}$ akkumulációt. Ez a hatás a citoszolikus SlAPX1 és -2 izoenzim gének repressziójával társult. Az APX specifikus aktivitásra vonatkozóan is hasonló megfigyelést tettek ACCD-t expresszáló rhizobaktériummal inokulált, sókezelésben részesített Catharanthus roseus növények leveleiben [282].

A $N r$ mutáció a 24 órás mintavételi időpontban erőteljesebben gátolta a POD müködését, mint az exogén ACC kezelés. Ezt megerősítve, Arabidopsis csíranövényekben az ein3eill mutáció csökkentette a POD aktivitását és transzkript szintjeit 3 napos sókezelést követően, így e növények nagyobb mértékü ROF akkumulációval és sóstressz hiperérzékenységgel rendelkeztek [266]. Ugyanakkor, a POD aktivitás csökkenése mellett a mutánsok leveleiben elmaradt a $250 \mathrm{mM} \mathrm{NaCl}$ indukálta gátlás a KAT specifikus aktivitásban, 
mely az SIKAT2 és SlKAT3 expressziós fokozódásával társítható. Bár az SlKAT3 sokkal nagyobb mennyiségben fejeződött ki a VT levelekben a letális sóstressz 24. óráját követően, mint a mutánsban, a 6. órában tapasztalható expressziós fokozódás a VT levelekben nem figyelhető meg. Érdekes módon, a szubletális sóstressz 6. óráját követő megfigyeléseink a POD aktivitás és az exogén ACC kapcsolatáról ellentétesnek bizonyultak Demir és Oztürk [265] tapasztalataival, a letális sóstressz 24. órájában megfigyeltek azonban jól illeszkednek az eredményeikhez, miszerint a levélre permetezett, exogén Ethephon mérsékeli, míg az ET hatás gátlása erősen csökkenti a POD aktivitást spenótlevélben, 5 órás sókezelést követően. A megfigyeléseink jól mutatják, hogy az ET mennyire komplex módon szabályozza a levél vizsgált enzimatikus antioxidánsainak aktivitását, valamint a ROF koncentrációját a kétféle erősségü sóstressz kialakulása során.

6.3.2.9. A levél NO és a ONOO- akkumulációjának szabályozása eltérö erösségü sókezelések során

A szubletális sókoncentráció csökkenti, a letális növeli a levél NO akkumulációját az 1. órában a VT növényekben, melyre az exogén ACC kezelés és a $N r$ mutáció csupán kisebb befolyással bírt. Ugyanakkor a megváltozott ET státusz szerepe a levél NO produkciójának szabályozásában szupraoptimális $\mathrm{NaCl}$ koncentrációk jelenlétében a 24. órában drasztikusan felerősödik. $100 \mathrm{mM} \mathrm{NaCl}$ kezelésnél mind exogén ACC, mind a mutáns ET receptor, az $\mathrm{Nr}$ jelenlétében, $250 \mathrm{mM} \mathrm{NaCl-nél} \mathrm{csak} \mathrm{ACC} \mathrm{elökezelés} \mathrm{mellett} \mathrm{kaptunk} \mathrm{jelentős} \mathrm{emelkedést} \mathrm{a}$ szöveti NO szintekben.

$\mathrm{Az}$ exogén ACC a $\mathrm{NO}$ felhalmozódás fokozása mellett a $\mathrm{ONOO}^{-}$szintjét is növeli szubletális sóstressz a 24. óráját követően, mely összefügghet a megemelkedett ET produkcióval. Eddig csak lúdfümagvakban figyelték meg, hogy az ACC alkalmazása tovább fokozta a sóindukált NO produkciót, mely kisebb mértékủ volt az ein3-1 mutánsban [197].

Érdekes módon, a $N r$ mutáns levelekben nem figyelhető meg növekedés a $\mathrm{ONOO}^{-}$ akkumulációban $250 \mathrm{mM}$-os $\mathrm{NaCl}$ kezelés alatt az első órában, holott megemelkedett $\mathrm{O}_{2}{ }^{*-}$ és NO produkciót detektáltunk bennük, viszont jelentősen megemelkedik a $\mathrm{ONOO}^{`}$ szintje a 24. órás mintában. Ahogy már említésre került, a $\mathrm{ONOO}^{-}$keletkezését a $\mathrm{O}_{2}{ }^{\bullet-}$ és a $\mathrm{NO}$ együttes lokalizációja szabja meg [273]. Továbbá a PRXR képes detoxifikálni a ONOO-et [77]. A $\mathrm{ONOO}^{-}$felhalmozódás csökkentheti a sejt $\mathrm{O}_{2}{ }^{*-}$ tartalmát, így végső soron védheti a biomolekulákat az oxidációtól és megakadályozhatja a további ROF termelődést [96].

Az exogén ACC jelentősen megemelte a levél NO tartalmat a 250 mM-os NaCl kezelés 24. óráját követően is, amellett, hogy kissé visszafogta a sóindukálta ET produkciót, és a $\mathrm{ONOO}^{-}$tartalmat is csökkentette. Az eredményeink a szakirodalmi példákkal megerősítve jól 
szemléltetik az ET szabályozó szerepét az említett ROF és RNF típusokra és antioxidáns enzimek aktivitására szubletális és letális sóstressz korai óráiban, továbbá rámutatnak az ET hatás vizsgálatakor az időbeni felbontás fontosságára, valamint az ET eltérő szerepére a levél és a gyökér ROF és RNF akkumulációs mintázatának a kialakulásában a sóstressz korai óráiban.

Összehasonlítva a tolerálható és sejthalált indukáló sóstressz hatását a levelekben megállapíthatjuk, hogy a letális sókoncentráció hatására jóval több $\mathrm{O}_{2}{ }^{*-}$ akkumulálódik a szövetekben, mint szubletális sóstressz esetén, amit csökkent az exogén ACC elökezelés és az $\mathrm{Nr}$ mutáció. Ehhez hasonlóan a $\mathrm{H}_{2} \mathrm{O}_{2}$ is nagyobb mértékü felhalmozódást mutat a $250 \mathrm{mM}$ $\mathrm{NaCl}$-dal kezelt növényekben, amit a 6 órás mintavételnél mindkét kezelés, 24 óra után az $\mathrm{Nr}$ mutáció tovább fokoz. Ennek alapján a szövetek komoly oxidatív stressznek vannak kitéve. Rövid távon sem a NO sem a ONOO` szintek nem emelkednek drámaian a kezelések hatására. Szubletális sóstressznél az ACC kezelt VT-ben és az Nr mutánsokban megemelkedő NO inkább a sótoleranciát fokozza, míg kisebb nitrozatív stressz kialakulhat a megemelkedett $\mathrm{ONOO}^{-}$ akkumuláció hatására a letális sókezelés 24. órájában, amit az exogén ACC mérsékel.

A nagy $\mathrm{O}_{2}{ }^{*-}$ tartalmak kialakulásához a képződést elősegítő folyamatok, így a PM-kötött NADPH oxidáz aktivitásának emelkedése és a fotoszintetikus elektrontranszport is hozzájárulhatnak a levelekben. Ezzel szemben a SOD aktivitás gyors emelkedése a gyökérrel ellentétben mind a szubletális, mind a letális sóstressznél csökkenti a $\mathrm{O}_{2}{ }^{\bullet}$ koncentrációt. Letális sóstressz során, a $\mathrm{H}_{2} \mathrm{O}_{2}$ ET státusz-függő akkumulációját a KAT és a POD, valamint az APX specifikus aktivitásának növekedése nem ellensúlyozta a 6. órában. Ugyanakkor ezen enzimek aktivitásának finomhangolása, különösen az APX esetében - melynek a korai aktivációja elmaradt az ACC kezelt/Nr növényekben - függ a levelek ET állapotától.

\subsubsection{Az ET státusz befolyásolja a fotoszintetikus aktivitást és a cukorháztartást paradicsomnövényekben sóstressz alatt}

6.3.3.1. Az ET státusz hatása a sztómakonduktanciára és a nettó $\mathrm{CO}_{2}$ asszimilációra szubletális és letális sóstressz alatt

A sóstressz csökkenti a sztómakonduktanciát és a fotoszintézist, egyrészt az ozmotikus komponens vízháztartásra gyakorolt kezdeti hatásán keresztül [162], másrészt a $\mathrm{Na}^{+}$és $\mathrm{Cl}^{-}$ ionok megzavarják nemcsak a sejt, hanem a kloroplasztisz ionhomeosztázisát is, mely szintén negatívan érinti a fotoszintetikus aktivitást [163, 166]. Mindez végső soron a biomasszatermelés csökkenéséhez vezet [154]. Sóstressz során a gyökérből a hajtásba történő szignalizációban kiemelt szerepe van az ACC-nek (így az ET-nek). Az ACC és néhány konjugált formája gyorsan transzportálható - akár percek alatt - a növények szöveteiben, a xilémen és a floémen keresztül is [118]. A korai, gyökérből kiinduló hormonális szignálok 
közül a citokininek és az ABA pozitívan, az ACC negatívan érintette a levélnövekedést, a kis xilém citokinin koncentráció vagy a nagy ACC tartalom szeneszcenciát indukált [283].

A tápoldathoz adott $100 \mathrm{mM}$-os $\mathrm{NaCl}$ rövid időn belül csökkentette a sztómakonduktanciát a VT paradicsomlevelekben, mely a 250 mM-os kezelés esetében jóval erösebbnek bizonyult. Ennek ellenére, a VT levelek fotoszintetikus $\mathrm{CO}_{2}$ asszimilációjában a későbbi időpontokban volt megfigyelhető jelentős gátlás, mely sokkal drasztikusabbnak bizonyult a letális koncentráció esetében. Bár a $\mathrm{RuBisCO}$ nem túl sóérzékeny, a $\mathrm{Na}^{+}$más $\mathrm{CBC}$ enzimek aktivitását csökkentheti, így a sóstressz közvetlenül is gátolhatja a fotoszintézist [163]. A $\mathrm{NaCl}$ kezelés paradicsomnövényekben egy hét után is szignifikánsan csökkentette a maximális $\mathrm{CO}_{2}$ asszimilációt, a karboxilációs hatékonyságot és növelte a $\mathrm{CO}_{2}$ kompenzációs pontot [205]. A szupraoptimális sókoncentráció korai - néhány órától 1-2 napig tartó - hatásaira adott növényi válaszreakció rendkívül fontos, mivel a szénasszimiláció komplett megszünése is bekövetkezhet órákon belül, a sótolerancia fenntartásához pedig szükség van a fotoszintetikus asszimilátumok nyújtotta energiára [284].

Az ET közvetlenül szabályozza a fotoszintézist fiatal/nem-szeneszcens levelekben és indirekt módon idősebb levelekben, elsősorban a szeneszcencia befolyásolásával [46]. Ennek ellenére az ET és a fotoszintézis kapcsolatát sóstressz során viszonylag kevés esetben vizsgálták. Az exogén ACC kezelés mérsékelte a sókezelések okozta ozmotikus sokk hatását, ami nemcsak a magasabb vízpotenciál értékekben, hanem a megnövekedett sztómakonduktanciában is megnyilvánult az első órai mintavételnél, mely a $100 \mathrm{mM}$-os $\mathrm{NaCl}$ koncentráció esetében a megfelelő sókezelésben részesített VT levelekhez képest csökkent, míg a $250 \mathrm{mM}$-os $\mathrm{NaCl}$ esetében a fokozott ET emisszióval párosult. A $\mathrm{Nr}$ mutánsokban stresszmentes állapotban is kisebb sztómakonduktanciát figyeltünk meg. Így a gyökérzóna sókezelése hatására a $\mathrm{g}_{\mathrm{sw}} 100 \mathrm{mM} \mathrm{NaCl}$ esetében csak 24 óra múlva, míg a $250 \mathrm{mM} \mathrm{NaCl-nál}$ már az 1. órás mintavételnél is szignifikánsan csökkent a megfelelő sókezelt VT-hez képest a $N r$ mutánsok leveleiben. Az ET-inszenzitív etrl-1 mutáns Arabidopsis levelek sztómái is csökkent vezetőképességgel rendelkeztek [46], tehát a normál sztómamüködéshez szükséges a funkcionális $N r$ receptor a paradicsomban is. A folyamatos ET expozícióban növekvő lúdfü növények, vagy a ctrl-1 konstitutív ET válasz mutánsok, több sztómával rendelkeztek.

A nettó $\mathrm{CO}_{2}$ fixáció követte a $\mathrm{g}_{\mathrm{sw}}$ változásait a különböző ET státusszal rendelkező növényekben sóstressz alatt. Míg a szubletális sókoncentráció kisebb mértékü, addig a letális sóstressz korábban jelentkező és drasztikus csökkenést eredményezett a VT növények $A_{N}$ értékeiben. A $N r$ levelek alapból kisebb $\mathrm{CO}_{2}$ asszimilációs értékekkel rendelkeztek, melyet a $100 \mathrm{mM} \mathrm{NaCl}$ okozta stressz jelentős mértékében csökkentett a 24. órára. Ebben az időpontban, 
a megfelelő sókoncentráció jelenlétében, az ACC kezelt növények $A_{N}$ értékét vizsgálva arra következtethetünk, hogy a funkcionális $N r$ receptor hiánya nagyobb befolyással van a folyamatra, mint a megemelkedett ET produkció. A lúdfü ET-inszenzitív mutánsban (etrl-1) alacsonyabb RuBisCO aktivitást, illetve néhány fotoszintézis-asszociált gén, mint például a $\mathrm{CAB}$ (klorofill $a / b$ kötő protein) és a RuBisCO kis alegység, csökkent mértékű expresszióját figyelték meg, ami arra utal, hogy az ET jelátvitel a fiziológiai hatásokon túlmenően elengedhetetlenül szükséges a kloroplasztisz struktúrájának kialakulásához is [46].

Mindezen túl, a sóstressz által indukált ET-termelés megemelkedése együtt jár a VT levélben a sztómazárás indukciójával, mely eltolódik, amennyiben a gyökeret ACC elökezelés után éri a stresszhatás. Yang és munkatársai [285] a búzanövényeket virágzásuk (anthesis) után 4 napig Ethephonnal permetezték. A kezelés végét követő 10. naptól a zászlós levelek $\mathrm{CO}_{2}$ asszimilációja és sztómakonduktanciája megnőtt. Továbbá, hosszútávú, erős szárazságstressz során, az említett kezelés hozzájárult a zászlós levelek $\mathrm{CO}_{2}$ asszimilációjának és sztómakonduktanciájának jobb megőrzéséhez, melyet magasabb ET produkció kísért. Érdekes módon, 24 óra elteltével, a $100 \mathrm{mM}$-os $\mathrm{NaCl}$ kezelés esetében intakt ET jelátvitel, így funkcionális $N r$ receptor szükséges a sztómák normális nyitottsági szintjének megőrzéséhez. Az ET képes gátolni a sötétség és az ABA indukált sztómazárást is [67, 68]. Mindez tovább erősíti az ET-nek, a stressz mértékének megfelelő sztómanyitottságot biztosító modulátorként betöltött funkcióját a paradicsomlevelekben. Hasonló megfigyeléseket tettek üvegházi körülmények között nevelt rizs hosszútávú sókezelése során. Az ET receptor gátló 1-MCP fotoszintézis serkentő hatása függött a fajta sóérzékenységétől is. Például a toleránsabb fajtában az 1-MCP magasabb sókoncentráción serkentette a fotoszintézist, míg az érzékeny fajtában kisebb sókoncentráción is [286]. A sóstressz csökkentette a mungóbab (Vigna radiata L.) nettó fotoszintézisét az ET produkció fokozásán keresztül [287].

A $\mathrm{CO}_{2}$ asszimiláció mértéke és a $\mathrm{C}_{\mathrm{i}} / \mathrm{C}_{\mathrm{a}}$ arány a szubletális sókezelést követően jól követte a sztómakonduktancia változásait, mely azt mutatja, hogy az ET, a $100 \mathrm{mM}-\mathrm{os} \mathrm{NaCl}$ jelenléte okozta stresszállapot kifejlődése során, 24 órán belül elsősorban a $\mathrm{CO}_{2}$ elérhetőségén keresztül befolyásolta a $\mathrm{CO}_{2}$ fixációt. Ugyanakkor letális sóstressz során, a 6. órától a sztomatikus faktorokon kívül egyéb folyamatok $\mathrm{CO}_{2}$ asszimilációt gátló hatása is felmerülhet, amire a $\mathrm{C}_{\mathrm{i}} / \mathrm{C}_{\mathrm{a}}$ arány növekedése utal. Ez a $\mathrm{Nr}$ mutánsokban kisebb mértékben következett be.

A VT levelek megemelkedett $\mathrm{C}_{\mathrm{i}} / \mathrm{C}_{\mathrm{a}}$ aránya a $250 \mathrm{mM} \mathrm{NaCl}$ kezelést követő 6. órában a sejtek $\mathrm{CO}_{2}$ kibocsájtásának megnövekedését mutatja a fogyasztás rovására, mely itt még egy minimális mértékü $\mathrm{CO}_{2}$ fixációs aktivitással társul. Ez a változás a 24. órára még drasztikusabbá vált, hiszen a növény $\mathrm{CO}_{2}$ kibocsájtása túlnőtte a $\mathrm{CO}_{2}$ fogyasztás mértékét, melyet a negatív $\mathrm{A}_{\mathrm{N}}$ 
értékek is mutatnak. Hasonló megfigyelést tettek búza levelek parakvát kezelése során, ahol a $\mathrm{C}_{\mathrm{i}}$ növekedése az $\mathrm{A}_{\mathrm{N}}$ és a RuBisCO tartalom csökkenésével társult. A parakvát a PSI akceptor oldalán elnyelt elektronokat az $\mathrm{O}_{2}$-re irányítja és így $\mathrm{O}_{2}$ “-ot generál [288] Ahogy már említésre került, a $250 \mathrm{mM}$-os $\mathrm{NaCl}$ a VT paradicsomlevelekben növelte az ET emissziót és erös $\mathrm{O}_{2}{ }^{*}$ akkumulációt indukált, melyet a $\mathrm{Nr}$ mutáció, valamint az exogén ACC a 6 . órában a $\mathrm{O}_{2}{ }^{*}$ elbontásának serkentésével, míg a 24. órában feltehetőleg a $\mathrm{O}_{2}{ }^{*-}$ produkció gátlásával vagy SOD-független kioltásával csökkent. A fotoszintetizáló sejtek $\mathrm{CO}_{2}$-ot fogyasztanak, azonban a mitokondriális légzés és a fotorespiráció során $\mathrm{CO}_{2}$ szabadul fel a sejtekben [289]. A mitokondriális légzés fenntartása alapvető, hogy kielégítse a sejtek ATP és egyéb metabolit szükségletét a sóstressz-válaszok kialakításában [290]. Rizsfajták hosszútávú sótürésének összehasonlításakor megfigyelték, hogy a sóstressz koncentrációfüggő módon megnövelte a levelek sötétlégzése során kibocsátott $\mathrm{CO}_{2}$ mértékét, mely az érzékenyebb genotípusokban meghaladta a kontroll állapotban fixált $\mathrm{CO}_{2}$ mennyiség felét erős sóstressz során [291]. Arabidopsis kalluszkultúrák kétnapos kezelése $100 \mathrm{mM} \mathrm{NaCl-dal} \mathrm{növelte} \mathrm{a} \mathrm{légzés} \mathrm{mértékét,}$ mely ein2-1 és az etrl-3 mutánsokban nem következett be. Ugyanakkor magasabb sókoncentrációk jelentősen csökkentették a légzés által fogyasztott $\mathrm{O}_{2}$ mennyiségét [292]. A fotorespiráció jelensége, mely a RuBisCO oxigenáz aktivitásának az eredménye, a már megkötött $\mathrm{CO}_{2}$-t szabadítja újra fel. Ennek ellenére, a fotorespiráció szintén fontos szabályozója a fotoszintézisnek, mivel elektronnyelő folyamat, mely megakadályozza az elektrontranszportlánc túlredukálódását és így a fotoinhibíciót. Különösen fontos ez a stresszfolyamatokban, melyek limitálják a fotoszintetikus $\mathrm{CO}_{2}$ asszimilációt [57]. Festuca pratensis levelek szeneszcenciája során a többszörösére nőtt a fotorespiráció mértéke [293]. Gyapot növények 3 napos sókezelését követően szintén megemelkedett fotorespirációt figyeltek meg, mely $\mathrm{O}_{2}{ }^{*-}$ akkumulációval és a nettó fotoszintézis csökkenésével társult [294]. Ezzel szemben, quinoa (Chenopodium quinoa Willd.) növények sós öntözővízzel történő kezelése során két hét elteltével csökkent a fotorespiráció [295]. Bár ET kezelés hatására foszforilálódott néhány, a fotorespirációban is résztvevő enzim borsó mitokondriumokban, e módosítás szerepét a folyamatban még nem tisztázták [296]. A VT paradicsomlevelek fokozott $\mathrm{CO}_{2}$ kibocsájtása és csökkent $\mathrm{CO}_{2}$ asszimilációja mellé a keményítőtartalom jelentős csökkenése is társul a letális sókezelés 6. és 24. óráját követően. Az ACC kezelés, illetve a $\mathrm{Nr}$ mutáció mindezeket mérsékelte.

Mint a 6.3.2. fejezetben láttuk, a különböző ET státuszú levelekben a különböző reaktív oxigénformák eltérő koncentrációban akkumulálódnak sóstressz alatt, amihez a fotoszintézis is hozzájárulhat. Másrészt ezek a molekulák közvetlenül szabályozhatják a fotoszintézist. Bár a 
$\mathrm{H}_{2} \mathrm{O}_{2}$ már $10 \mu \mathrm{M}$-os koncentrációban is gátolhatja a $-\mathrm{CBC}$ tiol-modulált enzimjeinek oxidálásán keresztül - a $\mathrm{CO}_{2}$ fixációt [297], a $250 \mathrm{mM}$-os sókezelés 6. órájában nem tapasztaltunk emelkedést a levél $\mathrm{H}_{2} \mathrm{O}_{2}$ koncentrációjában a VT levelekben, azonban az ACC kezelt és a $\mathrm{Nr}$ levelekben igen. Brassica juncea 24 órás időtartamú sókezelése során alacsonyabb és a magasabb sókoncentrációk is növelték a $\mathrm{O}_{2}{ }^{*-}$ mennyiségét, azonban a PSII aktivitásának szignifikáns csökkenését csupán az utóbbi esetben figyelték meg [274]. A VT levelekben erős $S l C u / Z n S O D$ génexpresszió indukciót is tapasztaltunk, mely közvetve jelezheti e kloroplasztisz-lokalizált enzim szükségességét. Bár a különbözö sejtkompartmentumokban képződő $\mathrm{H}_{2} \mathrm{O}_{2}$ pontos mennyiségének mérése nehezen megvalósítható [298], a megfigyeléseink alapján nem zárhatjuk ki a letális sókezelés indukálta $\mathrm{O}_{2}{ }^{-*}$, vagy $\mathrm{H}_{2} \mathrm{O}_{2}$ szerepét az $\mathrm{A}_{\mathrm{N}}$ csökkenésében a 6. órában, melyben lényeges szerep jut az ET-nek. Fontos megjegyezni, hogy a fotoszintetizáló, $\mathrm{C}_{3}$-as sejtekben a fotorespiráció peroxiszóma lokalizált, glikolát oxidáz reakciója az egyik leginkább szignifikáns $\mathrm{H}_{2} \mathrm{O}_{2}$ termelő folyamat [297].

A tapasztaltakat összevetve elmondható, hogy a letális sóstressz okozta fotoszintézis gátlás kialakulásához az első 24 órában a levél ET emisszió növekedése is hozzájárul, a funkcionális $\mathrm{Nr}$ receptor megléte pedig javítja a nettó $\mathrm{CO}_{2}$ asszimilációt szubletális sóstressznél. Elsőként földimogyoró levelekben figyelték meg, hogy az exogén ET gáz gátolja a fotoszintézist [59]. Saját megfigyeléseinkkel ellentétben, saláta csíranövények 13 napig tartó, gyökéren keresztül történő, $10 \mu \mathrm{M}$-os ACC kezelése szignifikánsan csökkentette a fotoszintetikus $\mathrm{CO}_{2}$ asszimilációt és a sztómakonduktanciát stresszmentes körülmények között [239]. Ez azt mutatja, hogy az ACC rövid távon más hatást gyakorol a fotoszintézisre, illetve, hogy ez a hatás különböző képpen jelentkezhet a fotoperiódus eltérő időszakaiban. Ezt a következtetést támasztja alá az is, hogy az ET felszabadulás kapcsolódhat a fotoszintetikus aktivitás változásához [122]. Fontos megjegyezni, hogy az ET részt vesz a stressz mértékének megfelelő válaszok kialakításában, a hormon mennyisége vagy éppen a jelátvitelének hiányossága ellentétes hatást válthatnak ki szubletális és letális stressz során a $\mathrm{CO}_{2}$ asszimilációban. ET-inszenzitív (etrl-1) lúdfü fiatal leveleiben csökkent, míg az idősebb levelekben megemelkedett RuBisCO aktivitás tapasztaltak a VT növényhez viszonyítva [46] ami azt mutatja, hogy az ET eltérő fiziológiai környezetben ellentétesen hathat a $\mathrm{CO}_{2}$ fixációra. 6.3.3.2. Az ET státusz hatása a klorofill a fluoreszcencia indukciós paraméterekre és a PSI aktivitásra szubletális és letális sóstressz alatt

$\mathrm{Az} \mathrm{F}_{\mathrm{V}} / \mathrm{F}_{\mathrm{M}}, \mathrm{F}_{0}$ és a $\mathrm{Y}(\mathrm{NO})$ klorofill fluoreszcencia paraméterekben nem tapasztaltunk jelentős változást a kísérlet során, mely arra enged következtetni, hogy a kezelések nem 
növelték a fotoinhibíciót 24 órán belül [298, 299]. Paradicsomnövények 7 és 15 napos sókezelése során sem figyeltek meg csökkenést az $\mathrm{F}_{\mathrm{V}} / \mathrm{F}_{\mathrm{M}}$ paraméterben, melyet nem befolyásolt az inokuláció egy ACCD enzimmel rendelkező baktériumtörzzsel [300].

A 100 mM-os NaCl kezelés nem befolyásolta a PSII és a PSI aktivitását az Ailsa Craig fajta VT leveleiben a kísérlet időtartama alatt, mely az ACC kezelt növényekben is hasonlóan alakult. Az Ailsa Craig fajtához hasonlóan egy hetes, 100 mM-os NaCl kezelés sem befolyásolta PSII maximális és effektív kvantumhatásfokát Fio Fuego fajtájú VT paradicsomlevelekben [205]. Az etrl-1, ET-inszenzitív Arabidopsis mutánsok alacsonyabb PSII aktivitással rendelkeztek [46], mely a paradicsom $\mathrm{Nr}$ mutánsok esetében csupán az 1 órás mintavételi ponton volt megfigyelhető. Ugyanakkor $100 \mathrm{mM} \mathrm{NaCl}$ hozzáadására a $\mathrm{Nr}$ mutánsok Y(II) értéke azonnali csökkenéssel válaszolt, mely nem regenerálódott a későbbi időpontokban sem. A jelenség háttérben a mutánsokban megfigyelhető erőteljesebb NPQ áll, melyet a 100 mM-os $\mathrm{NaCl}$ kezelés tovább fokoz a 6. órától. ET túltermelö, etol-1 és konstitutív ET válasz, ctrl-3 Arabidopsis mutánsokban defektust mutattak ki az NPQ kialakulásában, mivel a mutációk represszálták az NPQ legnagyobb hányadát adó, energia-függő kioltáshoz kapcsolódó xantofill ciklus egyik kulcsenzimének, a violaxantin-deepoxidáznak (VDE) az expresszióját, valamint a gátolták az enzim aktiválódását - a transztilakoidális $\Delta \mathrm{pH}$ csökkentéséből kifolyólag - magasabb fényintenzitásokon. A VDE expressziójának mesterséges megemelése a mutánsokban mérsékelte a fénystressz által fokozott fotoinhibíciót és a $\mathrm{O}_{2}{ }^{*}$ akkumulációt [301]. Letális sóstressz során, a $\mathrm{Nr}$ mutánsok a VT leveleknél nagyobb mértékü Y(NPQ) növekedéssel válaszoltak, mely kisebb Y(II) értékekhez vezetett.

A sókezelés indukálta, Y(II) csökkenéssel összhangban, a PSI donor oldali limitációja megnőtt a mutánsokban, ugyanakkor szimultán csökkent a Y(NA) mértéke, mely az erőteljesen aktiválódott CEF-PSI-nek köszönhető. Bár a letális sókezelést követő 6. és 24. órában ugyanez a VT levelekben is megfigyelhető, a változások mértéke viszont kisebb, szubletális stressz során pedig a mutánsokban leírt állapot nem alakul ki. Érdekes módon, a $250 \mathrm{mM}$-os NaCl kezelést követő első órában, a $\mathrm{Nr}$ mutánsokban nem jelentkeznek a többi esetben megfigyelt változások. Sóstressz során a $\mathrm{Nr}$ levelek jelentős mértékben megemelkedett, fényregulált NPQ értékeiért a CEF-PSI megemelkedése felelős. Ahogy már szóba került, a CEF képes elősegíteni a proton elektrokémiai potenciál grádiens $(\Delta \mathrm{pH})$ létrejöttét a tilakoidmembránokban és így a NPQ fokozásával megvédi a két fotokémiai rendszert a fotoinhibíciótól [243]. Ez további magyarázattal szolgál a Chen és Gallie [301] által, magasabb fényintenzitásokon megfigyelt, csökkent transztilakoidális $\Delta \mathrm{pH}$ értékek kialakulására intenzív ET jelátvitellel rendelkező Arabidposis mutánsokban, illetve megfigyeléseiket részben meg is erősíti az ellentétes ET 
jelátviteli változással rendelkező, $N r$ mutánsokban tapasztalt, fokozott NPQ. Tehát az ET képes szabályozni a CEF-PSI müködését a $N r$ receptoron keresztül sóstressz során.

Az exogén ACC kezelés során nem alakult ki a CEF-PSI, és így az NPQ indukciója a 250 mM-os NaCl hozzáadását követő 6 óra elteltével, mely megakadályozta a Y(II) csökkenést, valamint a $\mathrm{Y}(\mathrm{ND})$ megemelkedését. A letális sókoncentráció által indukált $\mathrm{CO}_{2}$ fixáció csökkenése azonban megnövelte a PSI akceptor oldali limitációját, ugyanakkor, ez nem okozott nettó változást a PSI aktivitásában. Ez az állapot hosszú távon fenntartva a PSI károsodásához is vezethet [302], melyet a Y(NO) enyhe megemelkedése is jelez. Mindazonáltal, a szóban forgó kezelés során megfigyeltek nem vezettek erős $\mathrm{O}_{2}{ }^{*-}$ akkumulációhoz a levélben. Bár a letális sóstressz 24. órájára az ACC kezelt növényekben is nőtt a Y(CEF)/Y(II) és az NPQ, ez előbbi alulmaradt a csak 250 mM-os NaCl-ot kapott, VT növények leveleihez mérten, így a PSI aktivitásában is nagyobb arányú csökkenés következett be. A CEF-PSI aktivitása sóstressz során alapvető szerepet játszhat, mivel nemcsak extra ATP-t termel, hanem csökkenti a ROF képződést is [163]. A magas sókoncentráció 4 napot követően, a PSII mellett a PSI fotoinhibícióját is eredményezte görögszéna levelekben, mely a PSI esetében az akceptor oldali változásokból fakadhat. Azonban, alacsonyabb sókoncentráción, illetve rövidebb expozíciós időt követően, a PSI limitációja a $\mathrm{CO}_{2}$ fixáció gátlásából fakadó, csökkent NADPH fogyasztásból adódhat [303]. Az általunk tapasztaltak felvetik annak a lehetőségét is, hogy míg a $\mathrm{Nr}$ levelekben a letális sókezelés esetében az RBOH1-függő müködés, addig az ACC kezelt növényekben a fotoszintetikus elektrontranszport játszhatott nagyobb szerepet a $\mathrm{O}_{2}{ }^{\bullet-}$ képződésében [302]. Természetesen, egyéb, általunk nem vizsgált faktorok is befolyásolhatják a $\mathrm{O}_{2}{ }^{*-}$ termelődését - melynek ismert keletkezési pontjai az irodalmi áttekintés során már említésre kerültek - a vizsgált csoportokban, azonban a megfigyeltek azt sugallják, hogy az ACC kezelt és a $\mathrm{Nr}$ növények leveleiben a $\mathrm{O}_{2}{ }^{*}$ produkció különböző eredetü lehet. A CitERF13 ET válasz transzkripciós faktor tranziens overexpresszáltatása dohánylevelekben szignifikánsan csökkentette a PSI és a PSII kvantumhatásfokát 2 nappal a CitERF13-at hordozó Agrobacterium tumefaciens szuszpenzióval történő infiltrálást követően. A PSI leszabályozása mögött ebben az esetben a PSII effektív kvantumhatásfokának NPQ-független csökkenése állt [72]. Tehát a két fotokémiai rendszer müködése nagyban befolyásolt a növények ET státusza által, továbbá, a $\mathrm{Nr}$ receptor „,kiesése” az ET-érzékelésből némileg más hatást gyakorol a PSI és PSII aktivitására a letális sóstressz korai időszakában, mint az exogén ACC kezelés okozta változások. Hosszú távú nehézfémstressznek kitett mustár növényekben, a levelek Ethephon kezelése mérsékelte a nikkel (Ni) és Zn okozta fotoszintézis gátlást a sztómakonduktancia, a RuBisCO aktivitás növelésén, valamint az NPQ csökkentésén keresztül, melyhez - a 250 mM- 
os $\mathrm{NaCl}$ alkalmazása során tett megfigyeléseinkhez hasonlóan - az ET-termelés enyhe csökkenése társult a levelekben [304]. Ez tovább erősíti azt a feltételezést, hogy az ET hatása a fotoszintézisre erős sóstressz során függhet a prekurzorok mennyiségétől is. Mindezen túl, a kísérleteink során nem figyeltünk meg jelentős változást a fényadaptált PSII reakciócentrumok nyitott állapotú frakciójában, mely tovább erősíti a megfigyelést, hogy a sóstressz e korai időszakában elsősorban a $\mathrm{CO}_{2}$ fixáció és így a PSI rendelkezik nagyobb érintettséggel, melyet jelentős mértékben befolyásol a $N r$ receptor és a gyökérzóna exogén ACC előkezelése, különösen a letális sókoncentráció esetében. Ezen túlmenően, míg a csökkent $\mathrm{CO}_{2}$ asszimiláció és a PSI-CEF ebből fakadó túlérzékenysége hosszú távon hátrányt jelenthet szubletális sóstressz során a $\mathrm{Nr}$ növényeknek, addig letális sóstressz során a levelek fotoszintetikus aktivitásának megőrzése rövidtávon akár jobb túlélési esélyeket jelenthet. Az SlETR5 homológ, CcEIN4 (Coffea canephora EIN4) antiszensz konstrukciót expresszáló, tehát az ET jelátvitelben gátolt paradicsom csíranövények magas sókoncentráción jobb növekedési paraméterekkel rendelkeztek, valamint sikeresebben örizték meg a hajtás $\mathrm{K}^{+} / \mathrm{Na}^{+}$arányát [305].

6.3.3.3. Az ET státusz hatása az oldható cukor- és a keményitő tartalomra szubletális és letális sóstressz alatt

A fotoszintézis ET státusz általi meghatározottságából következik, hogy az ET jelátvitel a fotoszintézis közvetlen termékeinek, az oldható szénhidrátoknak és a keményítőnek az akkumulációját is befolyásolja. A magas sókoncentrációjú talajokban a növényi szövetek, elsősorban a gyökér intercelluláris tereiben található sóoldatok ozmotikus potenciálja kibillenti az apoplaszt és szimplaszt közti vízpotenciál egyensúlyát, mely turgornyomás csökkenést és végül növekedésgátlást eredményez. Ebben a helyzetben a sejtek ozmotikus adaptációra való képessége határozza meg a túlélésüket [150]. Az ozmotikus adaptáció megtörténhet szervetlen ionok felvételével, ami közül a $\mathrm{Na}^{+}$fiziológiás koncentráció fölötti akkumulációja károsítja a fehérjék térszerkezetét, vagy kompatibilis ozmolitok akkumulálásával, melyek lehetnek egyszerü cukrok (pl. a glükóz, fruktóz), diszacharidok (pl. a szacharóz) vagy cukoralkoholok (pl. szorbitol). Feladatuk, hogy helyreállítsák a sejt ozmotikus potenciálját a metabolikus folyamatok gátlása nélkül. Továbbá ozmoprotektánsként védik a fehérjéket, a makromolekuláris aggregátumokat, a membránokat, illetve antioxindánsokként is funkcionálnak [152]. A CBC-ban keletkező glükózfoszfát átmenetileg a kloroplasztiszban raktározódik keményítő formájában, ami a sötétperiódusban hidrolízis után biztosítja a szénforrást a metabolizmus számára.

A VT gyökerek oldható cukor tartalmában megfigyelhetőek napszakos eltérések, melyet megváltoztat a $\mathrm{Nr}$ mutáció és az exogén ACC kezelés. A $100 \mathrm{mM}$ ill. $250 \mathrm{mM}$-os $\mathrm{NaCl}$ 
hozzáadását követő 1. óra elteltével a VT gyökerekben az oldható cukrok mennyiség csökkent a kezeletlen kontrollhoz képest, ezzel szemben intenzív keményítő felhalmozódás volt megfigyelhető az oldható cukrok mennyiségének rovására. A $100 \mathrm{mM}$-os NaCl-dal kezelt $\mathrm{Nr}$ és az ACC gyökerekben ebben az időpontban az oldható cukrok akkumulációja nagyobb a VTnél, keményítő felhalmozódás ugyanakkor nem változott. A VT és az ACC kezelt gyökerekben viszont szignifikáns mértékben megnőtt az oldható cukrok mennyisége a 6. órában. A 100 mMos NaCl-dal szemben a letális sókoncentráció kisebb befolyással bírt e gyökerek oldható cukortartalmára. Általánosságban az is megállapítható, hogy a kezeletlen $\mathrm{Nr}$ kontrollal összehasonlítva a sókezelések enyhébb hatást gyakoroltak $\mathrm{Nr}$ gyökerek oldható cukor akkumulációjára, mint a többi mintánál. A gyökerek keményítő tartalmában később csupán apróbb változások voltak tapasztalhatók.

Az ET sokféle szinten szabályozhatja a szövetek oldható szénhidrát tartalmát. Közvetlenül hathat a glükóz transzportjára a növényekben [306]. Az ET kezelés képes szabályozni a szénhidrátok transzport formája, a szacharóz szintéziséért és transzportjáert felelős gének expresszióját. Érdekes módon az ET felgyorsíthatja a cirkadián oszcillátort, hogy lerövidítse a cirkadián periódust, mely felborítható exogén szacharóz kezeléssel is [46].

A levelek oldható cukor és keményítő akkumulációja némileg eltérően alakult. A szubletális sókoncentráció, 24 órát követően intenzív oldható cukor felhalmozódást okozott a levelekben, mely ellentétesen alakult a gyökérben. A $N r$ mutáció mindkét esetben - az ACC kezelés csak a gyökérben - mérsékelte a hatást. A letális sókoncentráció nem emelte a levelek oldható cukor tartalmát a 24. órára, mely esetben a $N r$ mutáció és az exogén ACC kezelés kifejezetten serkentő hatásúnak bizonyult.-Az endogén ET megléte szükséges a szacharóz, raffinóz és sztachióz felhasználásához Medicago sativa L. szomatikus embriókban [307], ami összhangban van azzal, hogy az $N r$ mutánsok sóstressz alatt akkumulálják az oldható cukrokat mind a hajtásban, mind a gyökérben. Paradicsomnövények $100 \mathrm{mM} \mathrm{NaCl}$ kezelése ugyanakkor egy hét után csökkentette a szacharóz koncentrációt a gyökérben és a levélben, a glükóz és fruktóz tartalmat pedig csak a gyökérben, míg a hajtásban megnőtt a fruktóztartalom [205].

A $N r$ mutáns levelek a csökkent $\mathrm{CO}_{2}$ fixáció ellenére sokkal magasabb keményítő tartalommal rendelkeztek, mint a VT társaik, mely arra enged következtetni, hogy az ET jelátvitel szerepet játszik a keményítő bioszintézis, lebontás és a fotoszintézis közti egyensúly kialakulásában. Ugyanakkor, rizs ETR2 RNSi (RNS interferencia) mutánsok internodulusaiban csökkent keményítő akkumulációt figyeltek meg az $\alpha$-amiláz gén expressziójának fokozódása miatt [308], míg a magas ET emisszió gátolta a keményítő akkumulációt rizsben [286]. 
Steady state állapotban a fotoszintézis sebessége csökkenhet a citoszolikus anorganikus foszfát $\left(\mathrm{P}_{\mathrm{i}}\right)$ és a kloroplasztikus trióz-foszfátok cseréjének lassulása során. E körülmények között a fotoszintetikus termékek túlzottan akkumulálódnak a kloroplasztiszban és a nem megfelelő $\mathrm{P}_{\mathrm{i}}$ elérhetőség a belső keményítő raktározást favorizálja a fotoszintézis sebességének rovására. Hasonló jelenség történik a trióz-foszfátok citoszolikus felhalmozódása során is. A sóstressz lecsökkenti a redukált szénváz-elvonó eröt a növényekben, ami a felhasználó szövetek növekedésének gátlását eredményezi, mely keményítő felhalmozódáshoz vezet a szövetekben [309]. A sóstressz első 24 órájában ez nem jelent szignifikáns száraz tömeg csökkenést saját kísérletünkben a paradicsomnövényekben. $\mathrm{A} \mathrm{CO}_{2}$ asszimiláció sókezelések okozta csökkenése a levél keményítőtartalmát is csökkenti, mely a $\mathrm{Nr}$ levelekben nem, vagy csak kisebb mértékben következett be, továbbá, a 24. órára mindkét sókoncentráció esetében nőtt. A letális sóstressz okozta változások a levelek keményítő akkumulációjában merőben eltérőek a csak sókezelést kapott VT, illetve az ACC kezelt, vagy Nr mutáns növényekben. Míg az utóbbi kettő esetében intenzív keményítő raktározás figyelhető meg a 24. órában, addig a VT levelekben e raktárak kimerülése látható, mely jó összhangban van az $\mathrm{CO}_{2}$ asszimiláció változásaival. Amennyiben elégtelen mennyiségü keményítő szintetizálódik a fényperiódus során, a növényben szénéhezés léphet fel [309]. Szubletális sóstressz során azonban, a keményítő akkumuláció csökkenése leginkább az oldható cukrok mennyiségének növekedésével társul, mely pótolja a $\mathrm{CO}_{2}$ asszimiláció csökkenéséből fakadó energiahiányt, valamint növeli az ozmoprotektánsok mennyiségét [309]. A fotoszintézist limitáló környezetben a keményítő remobilizálása alapvető folyamat a szövetek redukált szénvázzal történő ellátásának fenntartásához [310]. Azzal kapcsolatbon, hogy a $\mathrm{NaCl}$ keményítő akkumulációt és ezzel társuló oldható cukor tartalom kimerülést okoz-e, vagy ennek a fordítottja igaz, ellentétes eredmények lelhetőek fel a szakirodalomban. Például sóadaptált eukaliptusz hajtásban, keményítő és az oldható cukrok felhalmozódását is megfigyelték [311], ugyanúgy ahogy a $N r$ levelekben a sókezeléseket követő 24. órában. Bár a $N r$ mutánsok oldható cukor tartalma a letális sóstressz 24. órájára jelentősen megnőtt, a vízpotenciál értékeiket nem voltak képesek megtartani, mely egyéb, kompatibilis ozmolitok szükségességét jelzi. Hasonló megfigyelést tettek Arabidopsis ein2-5 és ein3-1 ET inszenzitív mutánsokban vízhiány során, ahol az oldható cukrok mennyisége nőtt a kezeletlen növényhez képest, de egyes ozmotikusan aktív szénhidrátok - mint a glükóz a fruktóz és a szacharóz - akkumulációja viszont szignifikánsan alacsonyabb volt. Ebben az esetben azonban a VT levelek oldható cukor felhalmozása jóval nagyobb mértékünek bizonyult a mutánsokénál [99]. Továbbá, míg az ACC kezelt növények leveleiben, sóstressz során nem tapasztaltunk jelentős emelkedést az oldható cukor akkumulációban a többi kezeléshez 
viszonyítva, addig e növények jóval hatékonyabban őrizték meg vízpotenciáljukat, így kisebb mértékü ozmotikus stresszben részesültek, mint a $N r$, vagy a csak sókezelést kapott VT levelek. A megelőző fejezetekben tárgyaltuk, hogy az exogén ACC képes befolyásolni a levelek glükóz, fruktóz, szacharóz és szorbitol tartalmát is. Azonban feltételezhető, hogy az ACC-indukált ozmotikus adaptációban más, az oldható cukrokon kívüli komponensek is szerepet játszanak. Arabidopsis ein2-5 és ein3-1 mutánsokban a VT levelekhez viszonyítva csökkent a szacharóz tartalom sóstressz során, azonban a ctr1-1 mutánsokban ez megnőtt, ami azt mutatja, hogy az egyes mono- vagy diszacharidok akkumulációjának ET általi szabályozottsága fajonként eltérhet [196]. Az exogén ACC később kisebb mértékben befolyásolta a VT levelek keményítőtartalmában megfigyelhető, sókezelés indukálta változásokat.

A citoplazma vízpotenciáljának csökkenése a víz kiáramlása miatt „zsugoríthatja” a sejten belüli teret, mely inaktiválhatja a fotoszintézist. Ez összefüggésben lehet más enzimatikus változással is. A fruktóz-1,6-biszfoszfát (FBP) például akkumulálódhat a kloroplasztisz sztrómában alacsony vízpotenciál esetében a csökkent FBPáz aktivitás miatt, így a fruktóz-6-foszfát mennyisége lecsökken, mely limitálja a fotoszintézist [284].

\section{7. Összefoglalás}

A paradicsomnövények etilén (ET) érzékenységét és ET státusztól függő sóstressz-válaszait kétféle megközelítésben vizsgáltuk. Tanulmányoztuk egyrészt a gyökérközegben, hidropónikus kultúrában alkalmazott exogén 1-aminociklopropán-1-karbonsav (ACC) koncentráció sorozat hatását paradicsomnövények legfontosabb fiziológiai folyamataira, amellyel választ szerettünk volna kapni arra a kérdésre, hogy milyen hatást gyakorol a gyökérközegben, külső tényezők hatására megemelkedett ACC koncentráció azokra a mechanizmusokra, amelyek szerepet játszhatnak az indukált szerzett rezisztenciához hasonlóan egy ezt követő abiotikus stressz akklimatizáció folyamatának gyorsításában.

Második kísérlet sorozatunkban vizsgáltuk a szubletális $(100 \mathrm{mM})$ és a letális $(250 \mathrm{mM}$ $\mathrm{NaCl}$ ) sóstressz hatását különböző ET státuszú paradicsomnövények [vad típus (VT), $10 \mu \mathrm{M}$ ACC-vel elökezelt VT és ET receptor mutáns, Never ripe genotípus] sóstressz akklimatizációban szerepet játszó fiziológiai válaszaiban. Így tanulmányoztuk a vízháztartás, a fotoszintézis, valamint az oxidatív és nitrozatív stresszben szereplő különböző reaktív oxigén(ROF) és nitrogénformák (RNF) keletkezését, a ROF kioltásában szerepet játszó enzimek aktivitását, valamint a kódoló gének expresszióját a különböző ET státuszú növényekben a sóstressz akklimatizáció során, amellyel választ szerettünk volna kapni arra, hogy mi az ET szerepe a sóstressz-válasz korai időszakában. 
Fontosabb megfigyeléseinket az 5. melléklet foglalja össze grafikus formában.

Eredményeink alapján a következő megállapításokat fogalmaztuk meg:

1. A gyökérkezelésként adott ACC többlet egy koncentrációs küszöbértéket meghaladva indukál szignifikáns ET emissziót, ami a gyökerekben nagyobb mértékü, azonban ennek elérése nélkül is fiziológiai válaszokat vált ki.

2. A gyökérzónában bekövetkező, nagyon enyhe ACC koncentráció emelkedés (0,01-1 $\mu M)$ növeli a száraz biomassza gyarapodást a paradicsomnövények hajtásában, nitrozatív stresszt gátló környezetet alakít ki a ROF és RNF molekulák akkumulálódási mintázatában, a gyökércsúcsokban és a levélben egyaránt. Ugyanakkor a magas $(100 \mu \mathrm{M})$ ACC koncentráció száraztömeg csökkenést, valamint a ROF és RNF felhalmozódását eredményez. Az exogén ACC kezelés tehát növényi szerv és koncentráció-függő módon fokozta a $\mathrm{H}_{2} \mathrm{O}_{2}$ felhalmozódást, valamint befolyásolta a $\mathrm{NO}$ és a $\mathrm{ONOO}^{-}$akkumulációs mintázatát. Ugyanakkor a nagy koncentrációjú ACC kezelés sem okozta a növények pusztulását és az enyhe oxidatív stressz kedvező lehet az antioxidáns folyamatok aktiválásának elősegítésében.

3. Az exogén ACC jelenléte a gyökérzónában koncentráció és expozíciós idő függvényében serkentheti vagy gátolhatja a fotoszintézist és befolyásolja a két fotokémiai rendszer müködését nem öregedő paradicsomlevelekben. Az alacsony 0,01 és 1,0 $\mu \mathrm{M}$-os ACC koncentrációk a kezelés utáni első két napon serkentőleg hatnak a nettó $\mathrm{CO}_{2}$ fixációra, a 0,01 $\mu$ M-os ACC szignifikánsan emeli a PSI kvantumhatékonyságát és megváltoztatja a nem fotokémiai kioltási profilját, míg a PSII-re gyakorolt hatása csekély. A $100 \mu \mathrm{M}$-os ACC kezelés kifejezetten gátolja a nettó $\mathrm{CO}_{2}$ asszimilációt és a PSII effektív kvantumhatékonyságát, ezzel szemben a PSI kvantumhatásfoka kisebb érzékenységet mutat. Az ACC kezelések eltérő idő és intenzitásbéli lefolyással - indukálták a fényvédelmi folyamatokat, elsősorban a PSI ciklikus elektronáramlás (CEF-PSI) kapcsolt nem fotokémiai kioltás (NPQ) fokozásán keresztül.

4. A K ${ }^{+} / \mathrm{Na}^{+}$arányokban a $100 \mu \mathrm{M}$ ACC kezelés hatására kialakuló csökkenés enyhe sóstressznek tekinthető, ami priming hatású is lehet egy azt követő ozmotikus-/sóstressz akklimatizáció során, ennél fogva az ACC által kiváltott eustresszként definiálható. A 0,01-1,0 $\mu \mathrm{M}$ ACC növeli az oldható cukor és szorbitol tartalmakat, ami szintén hozzájárulhat egy ozmotikus komponenst is tartalmazó abiotikus stressztolerancia kialakításához. 
5. Az ET receptor mutációja a $N r$ paradicsomnövényekben fokozott érzékenységet eredményez a szupraoptimális sókoncentrációkkal szemben, a gyökércsúcsok már szubletális stressz esetén is mutatják a sejthalál jellegzetes fiziológiai tüneteit. Ennek oka a gyökércsúcsokban a szubletális $(100 \mathrm{mM})$ és letális $(250 \mathrm{mM}) \mathrm{NaCl}$ kezelés által kiváltott ROF és RNF akkumuláció. A VT gyökércsúcsokban a $\mathrm{O}_{2}{ }^{*-}$ a letális sókoncentráció hatására akkumulálódott, míg a $\mathrm{H}_{2} \mathrm{O}_{2}$ megnövekedett akkumulációja a tolerálható sóstressz esetén alakult ki. Az ET jelátvitelben blokkolt $N r$ növényekben a VT növények számára még tolerálható, $100 \mathrm{mM} \mathrm{NaCl}$ koncentrációnál is magas $\mathrm{O}_{2} \% / \mathrm{H}_{2} \mathrm{O}_{2}$ arány alakult ki, ami kedvező a programozott sejthalál (PCD) indukciója szempontjából. A detektált ROF/RNF akkumuláció következtében a nitro-oxidatív stressz jelentősebb lehet a $\mathrm{Nr}$ gyökerekben már alacsony $\mathrm{NaCl}$ koncentrációnál is. Ez nagyobb elektrolit-kieresztésben, fokozott DNS degradációban és a proteolízis, valamint a cisztein proteázok aktivitásának emelkedésében nyilvánult meg.

6. Az ET sóstressz akklimatizációban betöltött szerepét különböző ET státuszú növényekben vizsgáltuk. Megállapítottuk, hogy a $N r$ mutáció növelte a $\mathrm{K}^{+} / \mathrm{Na}^{+}$arány csökkenésében megnyilvánuló ionikus stresszt, míg az exogén ACC kezelés jelentősen mérsékelte a levélszövetek vízpotenciáljának csökkenését sóstressz alatt, ami az só-indukált ozmotikus stressz csökkenésére utal.

7. A növények ET státusza szabályozza a ROF és RNF molekulák akkumulációját a sóstressz kialakulása során. A gyökércsúcsokban mind az exogén ACC által indukált ET/ACC többlet, mind az ET jelátvitel blokkolása oxidatív, illetve nitrooxidatív stresszt váltott ki letális sóstressz alatt, amelynek hátterében eltérő mechanizmus áll. Bár mindkét esetben megemelkedett $\mathrm{a} \mathrm{O}_{2}{ }^{\bullet-}$ és $\mathrm{ONOO}^{-}$akkumuláció, ez exogén ACC kezelés mellett erőteljesebb. Míg a $\mathrm{O}_{2}{ }^{\bullet-}$ akkumulációt a $\mathrm{Nr}$-ban elsősorban a $\mathrm{SOD}$ gátlás okozza, a $\mathrm{H}_{2} \mathrm{O}_{2}$ elbontásához a mutánsban kisebb mértékben járul hozzá a KAT és rövid távon az APX, mint az ACC kezelt gyökerekben. Letális sóstressznél a gyökércsúcsok ET státuszának változása (exogén ACC, $N r$ ) növeli a sóérzékenységet.

Tolerálható sóstressznél azonban az exogén ACC kezelés jelentősen csökkenti a $\mathrm{O}_{2}{ }^{*-}$ felhalmozódását rövid távon, viszont nem csökkenti a $\mathrm{H}_{2} \mathrm{O}_{2}$ akkumulációt, ami mérsékeli az oxidatív stresszt. A korai $\mathrm{H}_{2} \mathrm{O}_{2}$ akkumuláció a VT gyökércsúcsokban lehetővé teszi olyan antioxidáns enzimek korai expresszió indukcióját (SIAPX2) és enzimatikus aktiválódását, mint az APX, míg a letális sókoncentrációnál a $\mathrm{H}_{2} \mathrm{O}_{2}$ lebomlásához a POD és a KAT aktivitás indukciója nagyobb mértékben járul hozzá, utóbbi különösen az ACC kezelt mintákban és a $N r$-ban jelentős. Ezekben a gyökércsúcsokban azonban az antioxidáns enzimek aktiválódásának ellenére a sóstressz hatására csökken a sejtek életképessége. 
8. A levelek 24 órán belül kisebb érzékenységet mutatnak a sóstresszel szemben, mint a gyökerek. Összehasonlítva a tolerálható és sejthalált indukáló sóstressz hatását a levelekben megállapíthatjuk, hogy a letális sókoncentráció hatására jóval több $\mathrm{O}_{2}{ }^{*}$ akkumulálódik a levélszövetekben is, mint szubletális sóstressz esetén, amit csökkent az exogén ACC előkezelés és a $\boldsymbol{N r}$ mutáció. Ehhez hasonlóan a $\mathrm{H}_{2} \mathrm{O}_{2}$ is nagyobb mértékü felhalmozódást mutat a $250 \mathrm{mM} \mathrm{NaCl-dal} \mathrm{kezelt} \mathrm{növényekben,} \mathrm{amit} \mathrm{a} 6$ órás mintavételnél az ACC előkezelés és a $\mathrm{Nr}$ mutáció tovább fokoz, így a szövetek komoly oxidatív stressznek vannak kitéve. Rövid távon sem a $\mathrm{NO}$ sem a $\mathrm{ONOO}^{-}$szintek nem növekedtek drámaian a kezelések hatására. Szubletális sóstressznél az ACC kezelt VT-ben és a $N r$ mutánsokban megemelkedő NO inkább a sótoleranciát fokozza, míg kisebb nitrozatív stressz kialakulhat a fokozott $\mathrm{ONOO}^{-}$akkumuláció hatására a letális sókezelés 24. órájában, ezt azonban az exogén ACC mérsékeli.

A nagy $\mathrm{O}_{2}{ }^{\bullet-}$ tartalmak kialakulásához a képződést elősegítő folyamatok (PM-kötött NADPH oxidáz aktivitásának emelkedése, fotoszintetikus elektrontranszport) is hozzájárulhatnak. A SOD aktivitás gyors emelkedése a gyökérrel ellentétben a letális sóstressznél csökkenti a $\mathrm{O}_{2}{ }^{*}$ koncentrációt 24 óra múltán. Az ACC előkezelt és a Nr mutáns levelekben ugyanakkor a VThez képest csökkent $\mathrm{O}_{2}{ }^{*-}$ akkumuláció figyelhető meg 24 óra elteltével, melyet azonban mérséklődött SOD specifikus aktivitás kísér, ami a $\mathrm{O}_{2}{ }^{\bullet-}$ generáló folyamatok csökkenésére utal. Letális sóstressz során, a $\mathrm{H}_{2} \mathrm{O}_{2}$ ET státusz-függő, korai akkumulációjáért az APX aktivitás csökkenése és a SOD aktivitás emelkedése okolható. Az intenzívebb SOD aktivitás generálta $\mathrm{H}_{2} \mathrm{O}_{2}$ felhalmozódást a KAT és a POD, valamint az APX specifikus aktivitásának növekedése sem volt képes ellensúlyozni a 6. órában, az ACC kezelt vagy a Nr levelekben. A letális sóstressz korai óráiban a SOD és $\mathrm{H}_{2} \mathrm{O}_{2}$ bontó enzimek aktivitásának finomhangolása szabályozza a levél $\mathrm{H}_{2} \mathrm{O}_{2}$ tartalmát, mely nagyban függ a levelek ET állapotától.

9. Az ET státusz befolyásolja a fotoszintetikus aktivitást és a cukorháztartást paradicsomnövényekben sóstressz alatt. A $100 \mathrm{mM}$-os $\mathrm{NaCl}$ rövid időn belül csökkentette a sztómakonduktanciát a VT paradicsomlevelekben, mely a 250 mM-os kezelés esetében jóval erősebbnek bizonyult, de az ACC előkezelés mindkét esetben mérsékelte a sóstressz hatását. A nettó $\mathrm{CO}_{2}$ asszimiláció mértéke és a $\mathrm{C}_{\mathrm{i}} / \mathrm{C}_{\mathrm{a}}$ arány a szubletális sókezelést követően jól követte a sztómakonduktancia változásait, mely azt mutatja, hogy az ET tolerálható sókoncentrációnál 24 órán belül elsősorban a $\mathrm{CO}_{2}$ elérhetőségén keresztül befolyásolta a $\mathrm{CO}_{2}$ fixációt. Ugyanakkor letális sóstressz során, a sztomatikus faktorokon kívül egyéb folyamatok $\mathrm{CO}_{2}$ asszimilációt gátló hatása is felmerülhet, amire a $\mathrm{C}_{\mathrm{i}} / \mathrm{C}_{\mathrm{a}}$ arány növekedése utal. Érdekes, hogy az $A_{N}$ csökkenése letális stressz esetén az ACC kezelt növények leveleiben vagy a $\mathrm{Nr}$ 
mutánsokban kisebb mértékben következett be, mint a megfelelö sókezelést kapott VT növények esetében. Az ET tehát részt vesz a stressz mértékének megfelelő válaszok kialakításában. A hormon mennyisége vagy éppen a jelátvitelének hiányossága ellentétes hatást válthatnak ki szubletális és letális stressz során a $\mathrm{CO}_{2}$ asszimilációban.

10. A sókezelések nem növelték a fotoinhibíciót 24 órán belül, mivel az $F_{V} / F_{M}, F_{0}$ és a $Y(N O)$ klorofill fluoreszcencia paraméterekben nem tapasztaltunk jelentős változást. A 100 mM-os $\mathrm{NaCl}$ kezelés nem befolyásolta a PSII és a PSI aktivitását az Ailsa Craig fajta VT leveleiben. Ugyanakkor $100 \mathrm{mM} \mathrm{NaCl}$ hozzáadására a $N r$ mutánsok Y(II) értéke jelentős azonnali csökkenéssel válaszolt, melynek háttérében a mutánsokban megfigyelhető magas NPQ áll, melyet a 100 mM-os só kezelés tovább fokoz.

A letális sókezelés indukálta Y(II) csökkenéssel összhangban, a PSI donor oldali limitációja megnőtt, ugyanakkor szimultán csökkent a Y(NA) mértéke, mely az erőteljesen aktiválódott CEF-PSI-nek köszönhető, ami a $N r$ levelek esetében még tovább fokozódott mindkét sókoncentráció esetében. A $100 \mathrm{mM}$-os és $250 \mathrm{mM}$-os $\mathrm{NaCl}$ kezelést követően a $\mathrm{Nr}$ levelek jelentős mértékben megemelkedett, fényregulált NPQ értékeiért a CEF-PSI megemelkedése felelös. Az exogén ACC kezelés a 250 mM-os $\mathrm{NaCl}$ hozzáadását követő 6 óra elteltéig gátolta a CEF-PSI növekedését és így a NPQ indukcióját, mely megakadályozta a Y(II) csökkenést, valamint a Y(ND) megemelkedését. Ez egyúttal azt is jelenti, hogy a PSII gátlását az exogén ACC kezelés késleltette, ugyanakkor a Y(NA) szimultán megemelkedésével megnövelte az esélyét az elektronok $\mathrm{O}_{2}$-re jutásának, illetve a PSI fotoinhibíciójának. Az ET tehát képes szabályozni a $\mathrm{CO}_{2}$ asszimilációt a sztómakonduktanciától függő és független módon, a fotoszisztémák kvantumhasznosítását és a fotoprotektív folyamatokat, így PSI-CEF müködését a $N r$ receptoron és az ACC elérhetőségén keresztül sóstressz során. Mindezek alapján PSI-CEF fontos és eddig ismeretlen résztvevőként javasolható abban a folyamatban, mely során az ET represszálja a NPQ legnagyobb hányadát adó, energiafüggő kioltáshoz kapcsolódó xantofill ciklus egyik kulcsenzimének, a violaxantindeepoxidáznak (VDE) az aktiválódását.

11. A $N r$ mutáns levelek a csökkent $\mathrm{CO}_{2}$ fixáció ellenére sokkal magasabb keményítő tartalommal rendelkeztek, mint a VT társaik, mely arra enged következtetni, hogy az ET jelátvitel szerepet játszik a keményítő bioszintézis/lebontás és a fotoszintézis közti egyensúly kialakulásában.

12. Az ET státusz változására a levél és a gyökér eltérően reagált. A gyökércsúcsok életképességét a sóstressz az ET státusztól függetlenül csökkentette, viszont mind az ACC előkezelt, mind a $N r$ gyökerek érzékenyebbnek bizonyultak a szubletális sóstresszre a VT-nál. 
Ez azonban még nem okozza a növényegyedek pusztulását, mert a hajtás sikeres akklimatizációja esetén újabb járulékos gyökerek indukálódhatnak. A levelekben az exogén ACC a $N r$ mutációval ellentétben több esetben növelte a sztómakonduktanciát és rövid távon a nettó $\mathrm{CO}_{2}$ asszimiláció mértékét, és a $N r$ mutációval szemben emelte e PSII kvantumhatékonyságát is, ami elősegítheti a hajtás adaptációját. Ugyanakkor, letális sókoncentráció jelenlétében, a $N r$ mutáció rövidtávon okozhat pozitív hatást egyes fiziológiai folyamatokra, mint például a fotokémiai rendszerek hatékonyabb fényvédelme és megtartott $\mathrm{CO}_{2}$ asszimilációs aktivitás. Ez azt mutatja, hogy a sikeres sóstressz akklimatizációt mind az ET többlet, mind az ET jelátvitel blokkolása gátolhatja szubletális sóstressz során, azonban eltérő kinetikával. Fontos azonban megjegyezni, hogy a különböző fiziológiai folyamatok finomszabályozottsága miatt ez nem közvetlenül vezet a növényegyedek pusztulásának fokozódásához. Ugyanakkor, csupán a $\mathrm{Nr}$ mutáció befolyásolta negatívan a levelek fotoszintetikus aktivitását szubletális sóstressz során a csökkent sztómakonduktancia és a túlérzékeny fényvédelmi mechanizmusok miatt. Eredményeink előrevetítik, hogy az ET tartalom vagy szignalizáció finomhangolása a stressz kifejlődésének bizonyos időpontjaiban, illetve az ET-termelés kinetikájának megváltoztatása jobban segítheti a sóstressz akklimatizációt. 


\section{Summary}

During our experiments, we investigated the ethylene (ET) sensitivity and the ET statusdependent salt stress responses of tomato plants using two different experimental designs. As a first approach, we applied different concentrations of exogenous 1-aminocyclopropane-1carboxylic acid (ACC) through the nutrient solution of hydroponically grown tomato plants to evaluate their effect on the most important physiological processes, which could possibly participate in the acclimation to a subsequent abiotic stress, as-an analogy for the inducible systemic resistance-mechanism.

As a second approach, we monitored the effects of sublethal $(100 \mathrm{mM} \mathrm{NaCl})$ and lethal $(250 \mathrm{mM} \mathrm{NaCl})$ salt stress on the acclimation mechanisms of tomato plants with different ET status [wild type (WT) plants pre-treated with $10 \mu \mathrm{M}$ ACC or ET receptor mutant, Never ripe genotypes], and compared their physiological responses to salt stress with WT plants of normal ET status. Therefore, we examined the water status parameters, photosynthetic activity, the accumulation of reactive oxygen- (ROF) and nitrogen forms (RNF) participating in oxidative and nitrosative stress in plant tissues or the activity and expression of ROF scavenging enzymes in plants of different ET status during the early stages of salt stress acclimation to evaluate the role of ET in these responses.

In accordance with our results, our conclusions are as follows:

1. Exogenous ACC applied through the root zone of WT tomato plants induced significant ET emission from the tissues especially in the roots, but only above a concentration threshold value. However, exogenous ACC induces physiological changes below this threshold as well.

2. Small increases in root zone ACC concentrations (0.01-1.0 $\mu \mathrm{M})$ enhanced dry biomass production in the shoots of WT tomato plants. Furthermore, the pattern of ROF/RNF generated by these treatments was unfavourable for the development of nitrosative stress, in plant root tips or leaf tissues. In contrast to low concetrations, the presence of high exogenous ACC concentration $(100 \mu \mathrm{M})$ in the root media induced a completely opposite response accompanied with enhanced ROF accumulation in the root apices and ROF/RNF accumulation in the leaves. In summary, exogenous ACC treatments induced enhanced $\mathrm{H}_{2} \mathrm{O}_{2}$ accumulation and affected the patterns of $\mathrm{NO}$ and $\mathrm{ONOO}^{-}$accumulation in concentration- or organ type dependent manner. Nevertheless, despite of the observed changes, the plants did not die even under high ACC concentration, furthermore, the weak oxidative stress can activate the antioxidant processes. 
3. The presence of exogenous $\mathrm{ACC}$ in the root zone could inhibit or stimulate photosynthesis and influence the activity of the photosystems in non-senescent tomato leaves in a concentration- and time dependent manner. Lower concentrations of ACC $(0.01$ and $1.0 \mu \mathrm{M}$ ) enhanced the net $\mathrm{CO}_{2}$ assimilation $\left(\mathrm{A}_{\mathrm{N}}\right)$ after the $1^{\text {st }}$ and $2^{\text {nd }}$ days. $0.01 \mu \mathrm{M}$ ACC significantly enhanced photosystem I (PSI) quantum efficiency and alter its nonphotochemical quenching profile, although the impact of this concentration on PSII efficiency was small. Furthermore, treatment with the very high, $100 \mu \mathrm{M}$ ACC had a pronounced inhibitory effect on $\mathrm{CO}_{2}$ assimilation and PSII quantum efficiency, however, PSI quantum efficiency showed smaller sensitivity. Photoprotective processes could be induced by all ACC concentrations with different kinetics and intensity, mostly through the enhancement of the PSI cyclic electron flow (CEF-PSI)-dependent non-photochemical quenching (NPQ).

4. The small, but significant decrease in the $\mathrm{K}^{+} / \mathrm{Na}^{+}$ratio caused by $100 \mu \mathrm{M}$ ACC could be considered as weak salt stress, which might serve as a hardening effect in a putative subsequent osmotic/salt stress acclimation process. Thus, this could be defined as an ACCinduced eustress. 0.01-1.0 $\mu \mathrm{M}$ ACC enhanced soluble sugar and sorbitol contents, which may contribute to the development of tolerance to an abiotic stress possessing an osmotic component.

5. The mutation of the ET receptor in $\mathrm{Nr}$ tomato plants resulted in enhanced susceptibility to supraoptimal salt concentrations. Root apical segments showed typical physiological symptoms of cell death even under sublethal stress, due to excess ROF and RNF accumulation in root tips caused by sublethal or lethal $\mathrm{NaCl}$ concentrations. In WT root tips, the accumulation of $\mathrm{O}_{2}{ }^{*-}$ occurred during lethal salt stress, and $\mathrm{H}_{2} \mathrm{O}_{2}$ accumulated in the presence of sublethal salt concentration. In contrast to WT, $\mathrm{Nr}$ root apices blocked in ET signalling showed higher $\mathrm{O}_{2}{ }^{*} / \mathrm{H}_{2} \mathrm{O}_{2}$ ratio even under $100 \mathrm{mM} \mathrm{NaCl}$ treatment, which is favourable for the induction of programmed cell death (PCD). Because of the detected ROF and RNF accumulation, the nitro-oxidative stress was more pronounced in $\mathrm{Nr}$ root apices even at $100 \mathrm{mM} \mathrm{NaCl}$. This led to higher electrolyte leakage, enhanced DNA fragmentation, proteolysis and cysteine protease activity.

6. Examining the role of ET in salt stress acclimation of plants with different ET status, it was concluded that the $\mathbf{N r}$ mutation promoted ionic stress, which manifested in a decreased $\mathrm{K}^{+} / \mathrm{Na}^{+}$ratio, while exogenous ACC prevented the salt induced loss in leaf water potential, thus, lowered osmotic stress under salt stress. 
7. ET status of plants controls the accumulation of ROF and RNF molecules during the development of salt stress. In root apices, both excess ET/ACC contents caused by exogenous ACC and the inhibition of ET signalling resulted in oxidative or nitro-oxidative stress under lethal salt stress, although the underlying mechanisms were different. Despite the observation, that the accumulation of $\mathrm{O}_{2}{ }^{--}$and $\mathrm{ONOO}^{-}$was enhanced at both conditions, this was higher in the case of ACC-treated WT root tips. While the cause of $\mathrm{O}_{2}{ }^{--}$accumulation in $\mathrm{Nr}$ roots was the inhibition of superoxide dismutase (SOD), the contribution of catalase (CAT) and - in the early hours - ascorbate peroxidase (APX) enzymes to the decomposition of $\mathrm{H}_{2} \mathrm{O}_{2}$ were less intensive in the mutant than in ACC-treated roots. In summary, under lethal salt stress, the change of ET status (exogenous ACC, $\mathrm{Nr}$ mutation) in root tips enhanced salt sensitivity. In contrast to this, under tolerable salt stress, exogenous ACC alleviated the accumulation of $\mathrm{O}_{2}{ }^{*-}$ in the early hours, but not that of $\mathrm{H}_{2} \mathrm{O}_{2}$, which in the end, helped to mitigate oxidative stress. Early $\mathrm{H}_{2} \mathrm{O}_{2}$ accumulation in root apices allows a faster induction of the expression and activity of antioxidant enzymes, as it can be seen in the case of SIAPX2 or APX, respectively, while under lethal salt stress, the induction of CAT and guaiacol peroxidase (POD) specific activities contributed in $\mathrm{H}_{2} \mathrm{O}_{2}$ decomposition at a higher extent, which at certain time points were more significant in ACC-treated or $\mathrm{Nr}$ roots. At the same time, despite the activation of antioxidant enzymes, the cell viability in root apices was significantly reduced in these samples due to lethal salt stress.

8. The leaves showed lower sensitivity than the roots to salt stress within 24 hours. Comparing the tolerable and the cell death-inducing salt stress effects in the leaves, we could conclude that under the latter condition, much greater $\mathrm{O}_{2}{ }^{\circ-}$ accumulation was detected, which could be reduced by exogenous ACC pre-treatment or $\mathrm{Nr}$ mutation. Similarly, higher $\mathrm{H}_{2} \mathrm{O}_{2}$ levels could be observed at $250 \mathrm{mM} \mathrm{NaCl}$ concentrations, which was further enhanced by both ACC treatment or $\mathrm{Nr}$ mutation after 6 hours, thus, these tissues were exposed to severe oxidative stress. In shorter time interval, dramatic increase in $\mathrm{NO}^{-} \mathrm{ONOO}^{-}$ accumulation could not be observed during the treatments. Under sublethal salt stress, elevated NO levels in ACC-treated or $\mathrm{Nr}$ mutant plants rather enhanced salt tolerance, while slight nitrosative stress could be developed due to greater $\mathrm{ONOO}^{-}$accumulation after 24 hours under lethal salt stress, which was alleviated by exogenous ACC.

The processes, which facilitate the formation $\mathrm{O}_{2}{ }^{\bullet}$, such as photosynthetic electron transport or plasma membrane (PM)-bound NADPH oxidase, might participate in developing high $\mathrm{O}_{2}{ }^{\bullet-}$ levels. The rapid enhancement of SOD activity - in contrast to the roots - decreases $\mathrm{O}_{2}{ }^{*-}$ concentration under lethal salt stress after 24 hours. However, decreased $\mathrm{O}_{2}{ }^{\bullet-}$ accumulation 
observed in ACC treated and the mutant leaves after 24 hours was paired with lower SOD specific activity compared to salt treated WT leaves, which indicates a decrease in $\mathrm{O}_{2}$ generating processes.

Under lethal salt stress, decreased APX and enhanced SOD specific activity contributed to the early accumulation of $\mathrm{H}_{2} \mathrm{O}_{2}$ in ACC treated or Nr leaves. Later, in ACC treated or $\mathrm{Nr}$ leaves, neither CAT, POD nor APX could alleviate $\mathrm{H}_{2} \mathrm{O}_{2}$ accumulation generated by increased SOD specific activity in ACC treated/Nr leaf samples. Thus, the fine tuning in SOD and $\mathrm{H}_{2} \mathrm{O}_{2}$ scavenging enzyme activity regulate $\mathrm{H}_{2} \mathrm{O}_{2}$ content of leaves during lethal salt stress, which is highly depends on ET status of leaves.

\section{ET status influences photosynthetic activity and sugar homeostasis in tomato plants} under salt stress. $100 \mathrm{mM} \mathrm{NaCl}$ added to root media decreased stomatal conductance rapidly in WT tomato leaves, this response was stronger under lethal salt stress, however, ACC treatment mitigated this salt induced effect in both cases. Net $\mathrm{CO}_{2}$ assimilation and $\mathrm{C}_{\mathrm{i}} / \mathrm{C}_{\mathrm{a}}$ ratio were in good correlation with the changes in stomatal conductance under sublethal salt stress in all treatments, which showed that ET could control $\mathrm{CO}_{2}$ fixation mostly by the availability of $\mathrm{CO}_{2}$ in these samples. However, under lethal salt stress, besides stomatal factors, other processes could have been involved in the inhibition of $\mathrm{CO}_{2}$ assimilation, as it is confirmed by the increase in $C_{i} / C_{a}$. Interestingly, the decrease in $A_{N}$ or the increase in $C_{i} / C_{a}$ were significantly lower in the leaves of ACC treated or $\mathrm{Nr}$ plants under lethal salt stress, compared to WT plants. Thus, ET participates in the development of salt stress responses as a function of stress intensity. The amount of the hormone or the impairment of its signalling caused contrasting effects during sublethal and lethal salt stress in $\mathrm{CO}_{2}$ assimilation.

10. Salt treatments did not enhance photoinhibition in 24 hours, as it could be observed in $\mathrm{F}_{\mathrm{V}} / \mathrm{F}_{\mathrm{M}}, \mathrm{F}_{0}$ and $\mathrm{Y}(\mathrm{NO})$ chlorophyll fluorescence parameters. Treatment with $100 \mathrm{mM} \mathrm{NaCl}$ did not affect PSII and PSI activity in the leaves of Ailsa Craig tomato cultivar. However, in the presence of $100 \mathrm{mM} \mathrm{NaCl}$, the $\mathrm{Y}$ (II) values of $\mathrm{Nr}$ mutants decreased immediately, which is caused by higher, and more sensitive NPQ response in these plants.

In good accordance with the reduction in Y(II) by lethal salt stress, the donor side limitation of PSI was enhanced with the simultaneous decrease in Y(NA) due to elevated CEF-PSI, which was further enhanced in the mutants during both salt stresses. Therefore, the enhanced, light regulated NPQ values under salt stress were induced by increased CEF-PSI in $\mathrm{Nr}$ mutants.

Interestingly, until the $6^{\text {th }}$ hour of $250 \mathrm{mM} \mathrm{NaCl}$ treatment, exogenous ACC inhibited the induction of CEF-PSI, and therefore the induction of NPQ, which prevented the decrease of $\mathrm{Y}(\mathrm{II})$ or the consequent increase of $\mathrm{Y}(\mathrm{ND})$. This shows that, exogenous ACC delayed the 
decrease in PSII activity, but enhanced Y(NA), which governs the chance of a higher electron flow toward $\mathrm{O}_{2}, \mathrm{O}_{2}{ }^{*-}$ formation and PSI photoinhibition. Thus, ET could regulate net $\mathbf{C O}_{2}$ assimilation through stomatal or non-stomatal factors, the quantum efficiency of the photosystems and photoprotective mechanisms, including PSI-CEF operation due to $\mathrm{Nr}$ receptor and the availability of ACC under salt stress. Nevertheless, PSI CEF could be suggested as an important and unknown participant in the process, during which ET represses the activation of violaxanthin-deepoxidase - key enzyme in xanthophyll cycle which highly contributes to the greatest NPQ subfraction, the energy dependent quenching.

11. Despite the lower $\mathrm{CO}_{2}$ fixation activity, $\mathrm{Nr}$ mutant leaves possess significantly higher starch content than WT leaves, which could lead to the conclusion, that ET signalling helps to maintain the balance between starch metabolism and photosynthesis.

12. The response of roots and leaves to the change in ET status was different. Cell viability in root apices was decreased by salt stress, and both ACC-treated and $\mathrm{Nr}$ mutant root tips were more sensitive to sublethal salt exposure than WT. However, this did not necessarily increase mortality of plant individuals, because after a successful acclimation process in the shoot, newly formed adventitious roots could be induced. In contrast to $\mathrm{Nr}$ mutation, exogenous ACC enhanced stomatal conductance and net $\mathrm{CO}_{2}$ assimilation in a short time interval and increased the quantum efficiency of PSII, therefore, it promoted the adaptation of the shoot. However, under lethal salt stress, $\mathrm{Nr}$ mutation or impaired ET signalling could induce positive changes in certain physiological processes, like more successful photoprotection and $\mathrm{CO}_{2}$ assimilation. This indicates that under sublethal salt stress, both supraoptimal ET/ACC concentrations or the block in ET signalling decreases success of salt acclimation in the roots, but with different kinetics. It must be noted, that this was not necessarily leaded to plant decay because of fine regulation of physiological processes. However, only $\mathrm{Nr}$ mutation affected photosynthesis negatively under sublethal salt stress, due to oversensitive photoprotection and decreased stomatal conductance. Our results also anticipate that in certain time points of stress development, the fine tuning of ET contents or signalling, the alteration in the kinetics of ET production would help the salt acclimation process. 


\section{Irodalomjegyzék}

1 Light, K.M., Wisniewski, J.A., Vinyard, W.A., Kieber-Emmons, M.T., 2016. Perception of the plant hormone ethylene: known-knowns and known-unknowns. J. Biol. Inorg. Chem. 21, 715-728.

2 Pierik, R., Tholen, D., Poorter, H., Visser, E.J.W., Voesenek, L.A.C.J. (2006) The Janus face of ethylene: growth inhibition and stimulation. Trends plant sci, 11(4), 176.

3 Trobacher, C.P. (2009) Ethylene and programmed cell death in plants. Botany, 87(8), 757. Arabidopsis cell wall proteome defined using multidimensional protein identification technology. Proteomics. 6: 301-311.

4 Van Doorn W.G., Beers P.E., Dangl L.J., Franklin-Tong E.V., Gallois P., Hara-Nishimura I., et al. (2011): Morphological classification of plant cell deaths. Cell Death Differ. 18(8), 1241.

5 Alagna, F., Kallenbach, M., Pompa, A., De Marchis, F., Rao, R., Baldwin, I.T., Bonaventure, G., Baldoni, L. (2015) Olive fruits infested with olive fly larvae respond with an ethylene burst and the emission of specific volatiles. J Integr Plant Biol, 58(4), 413-425.

6 Alazem, M. and Lin, N.-S. (2015) Roles of plant hormones in the regulation of host?virus interactions. Mol. Plant Pathol., 16(5), 529

7 Kazan, K., 2015. Diverse roles of jasmonates and ethylene in abiotic stress tolerance. Trends Plant Sci. 20, $219-229$.

8 Iqbal, N., Nazar, R., Khan, M.I.R., Khan, N.A., 2012. Variation in photosynthesis and growth of mustard cultivars: Role of ethylene sensitivity. Sci. Hortic. 135, 1-6.

9 Santner A, Calderon-Villalobos LIA, Estelle M (2009) Plant hormones are versatile chemical regulators of plant growth. Nature Chem Biol 5, 301-307

10 Raskin, I. and Beyer, E.M. (1989) Role of Ethylene Metabolism in Amaranthus retroflexus. Plant Physiol, 90(1), 1.

11 Argueso, C.T., Hansen, M., Kieber, J.J., 2007. Regulation of ethylene biosynthesis. J. Plant Growth Regul. 26, 92-105.

12 McDonnell, L., Plett, J. M., Andersson-Gunnerås, S., Kozela, C., Dugardeyn, J., Van Der Straeten, D., ... \& Regan, S. (2009). Ethylene levels are regulated by a plant encoded 1-aminocyclopropane-1-carboxylic acid deaminase. Physiol. Plant., 136(1), 94-109.

13 Zhang, Z., Zhang, H., Quan, R., Wang, X. C., \& Huang, R. (2009). Transcriptional regulation of the ethylene response factor LeERF2 in the expression of ethylene biosynthesis genes controls ethylene production in tomato and tobacco. Plant Physiol., 150(1), 365-377.

14 Ruduś, I., Sasiak, M., Kepczyński, J., 2013. Regulation of ethylene biosynthesis at the level of 1-aminocyclopropane-1carboxylate oxidase (ACO) gene. Acta Physiol. Plant. 35, 295-307.

15 Zemlyanskaya, E. V., Omelyanchuk, N.A., Ermakov, A.A., Mironova, V. V., 2017. Mechanisms regulating ethylene signal transduction in plants. Russ. J. Genet. Appl. Res. 7, 335-344.

16 Van de Poel B, Van Der Straeten D (2014) 1-Aminocyclopropane-1-carboxylic acid (ACC) in plants: more than just the precursor of ethylene! Front Plant Sci 5, 640.

17 Shin K, Lee S, Song W-Y, Lee R-A, Lee I, Ha K, Koo J-C, Park S-K, Nam H-G, Lee Y, Soh M-S (2015) Genetic identification of ACC-RESISTANT2 reveals involvement of LYSINE HISTIDINE TRANSPORTER1 in the uptake of 1aminocyclopropane-1-carboxylic acid in Arabidopsis thaliana. Plant Cell Physiol 56, 572-582.

18 Cara, B. and Giovannoni, J.J. (2008) Molecular biology of ethylene during tomato fruit development and maturation. Plant Sci., 175(1-2), 106.

19 Shakeel, S.N., Gao, Z., Amir, M., Chen, Y.-F., Rai, M.I., Haq, N.U., Schaller, G.E. (2015) Ethylene Regulates Levels of Ethylene Receptor/CTR1 Signaling Complexes in Arabidopsis thaliana. J. Biol. Chem., 290(19), 12415-12424.

20 Liu, Q., Wen, C.K., 2012. Cooperative ethylene receptor signaling. Plant Signal. Behav. 7(8), 1009-1013.

21 Lin, Z., Grierson, D., 2010. New perspective in ethylene signaling Plant Signal. Behav. 5:5, 545-549.

22 Mubarok, S., Hoshikawa, K., Okabe, Y., Yano, R., Tri, M.D., Ariizumi, T., Ezura, H., 2019. Evidence of the functional role of the ethylene receptor genes SIETR4 and SIETR5 in ethylene signal transduction in tomato. Mol. Genet. Genomics 294, 301-313.

23 Liu, M., Pirrello, J., Chervin, C., Roustan, J.-P., and Bouzayen, M. (2015). Ethylene control of fruit ripening: revisiting the complex network of transcriptional regulation. PlantPhysiol. 169(4), 2380-2390.

24 Wilkinson JQ, Lanahan MB, Yen HC, Giovannoni JJ, Klee HJ (1995) An ethylene-inducible component of signal transduction encoded by never ripe. Science 270, 1807-1809.

25 Rick CM, Butler L (1956) Phytogenetics of the tomato. Adv Genet. 8, 267-382.

26 Mata CI, Fabre B, Parsons HT, Hertog MLATM, Van Raemdonck G, Baggerman G, Van de Poel B, Lilley KS and Nicolaï BM (2018) Ethylene Receptors, CTRs and EIN2 Target Protein Identification and Quantification Through Parallel Reaction Monitoring During Tomato Fruit Ripening. Front. Plant Sci. 9, 1626.

27 Tieman, DM, Taylor, MG, Ciardi, JA, Klee HJ (2000) The tomato ethylene receptors NR and LeETR4 are negative regulators of ethylene response and exhibit functional compensation within a multigene family. Proc. Natl. Acad. Sci. USA, 97, 5663-5668.

28 Lanahan, M.B., Yen, H.C., Giovannoni, J.J., Klee, H.J., 1994. The never ripe mutation blocks ethylene perception in tomato. Plant Cell 6, 521-530.

29 Wang, J., Chen, G., Hu, Z., \& Chen, X. (2007). Cloning and characterization of the EIN2-homology gene LeEIN2 from tomato: Full Length Research Article. DNA seq., 18(1), 33-38.

30 Zhong S, Lin Z, Grierson D (2008) Tomato ethylene receptors-CTR interactions: visualization of NEVER-RIPE interactions with multiple CTRs at the endoplasmatic reticulum. J Exp Bot 59, 965-972.

31 Zhong, S., Chang, C., 2012. Ethylene Signalling: The CTR1 Protein Kinase. In: McManus, M. T. (Ed.). Annual plant reviews, the plant hormone ethylene. 44, 147-168. John Wiley \& Son 
32 Liu, M., Pirrello, J., Kesari, R., Mila, I., Roustan, J. P., Li, Z., ... \& Regad, F. (2013). A dominant repressor version of the tomato S l-ERF. B 3 gene confers ethylene hypersensitivity via feedback regulation of ethylene signaling and response components. Plant J., 76(3), 406-419.

33 Rai, M.I., Wang, X., Thibault, D.M., Kim, H.J., Bombyk, M.M., Binder, B.M., Shakeel, S.N., Schaller, G.E. (2015) The ARGOS gene family functions in a negative feedback loop to desensitize plants to ethylene. BMC Plant Biol., 15(1), 1.

34 Wang, Y., Wang, Q., Gao, L., Zhu, B., Ju, Z., Luo, Y., Zuo, J., 2017a. Parsing the Regulatory Network between Small RNAs and Target Genes in Ethylene Pathway in Tomato. Front. Plant Sci. 8, 1-13.

35 Wang, Y., Gao, L., Li, J., Zhu, B., Zhu, H., Luo, Y., Wang, Q., Zuo, J., 2018. Analysis of long-non-coding RNAs associated with ethylene in tomato. Gene 674, 151-160.

36 Yen, H.C., Lee, S., Tanksley, S.D., Lanahan, M.B., Klee, H.J., Giovannoni, J.J., 1995. The Tomato Never-ripe Locus Regulates Ethylene-Inducible Gene Expression and Is Linked to a Homolog of the Arabidopsis ETR1 Gene. Plant Physiol. $107,1343-1353$.

37 Hirayama, T., Kieber, J. J., Hirayama, N., Kogan, M., Guzman, P., Nourizadeh, S., ... \& Ecker, J. R. (1999). RESPONSIVETO-ANTAGONIST1, a Menkes/Wilson disease-related copper transporter, is required for ethylene signaling in Arabidopsis. Cell, 97(3), 383-393.

38 Lacey, R.F. and Binder, B.M. (2014) How plants sense ethylene gas - The ethylene receptors. J. Inorg. Biochemistry, 133, 58-62

39 Lin, Z., Alexander, L., Hackett, R., Grierson, D., 2008. LeCTR2, a CTR1-like protein kinase from tomato, plays a role in ethylene signalling, development and defence. Plant J. 54, 1083-1093.

40 Gallie, D.R. (2015) Ethylene receptors in plants - why so much complexity? F1000Prime Reports, 7, 39.

41 Pirrello, J., Prasad, B. N., Zhang, W., Chen, K., Mila, I., Zouine, M., és mtsai. (2012). Functional analysis and binding affinity of tomato ethylene response factors provide insight on the molecular bases of plant differential responses to ethylene. BMC Plant Biol. 12(1), 190.

42 Wang, F., Cui, X., Sun, Y., Dong, C.-H. (2013) Ethylene signaling and regulation in plant growth and stress responses. Plant Cell Rep. 32(7), 1099.

43 Klee, H.J., 2002. Control of ethylene-mediated processes in tomato at the level of receptors. J. Exp. Bot. 53, $2057-2063$.

44 Klay, I., Gouia, S., Liu, M., Mila, I., Khoudi, H., Bernadac, A., Bouzayen, M., Pirrello, J., 2018. Ethylene Response Factors (ERF) are differentially regulated by different abiotic stress types in tomato plants. Plant Sci. 274, 137-145.

45 Cherepanov, D. A., Milanovsky, G. E., Petrova, A. A., Tikhonov, A. N., \& Semenov, A. Y. (2017). Electron transfer through the acceptor side of photosystem I: Interaction with exogenous acceptors and molecular oxygen. Biochemistry (Moscow), 82(11), 1249-1268.

46 Ceusters J, Van de Poel B (2018) Ethylene exerts species-specific and age-dependent control of photosynthesis. Plant Physiol 176:2601-2612

47 Baker, N. R., \& Rosenqvist, E. (2004). Applications of chlorophyll fluorescence can improve crop production strategies: an examination of future possibilities. J exp bot. 55(403), 1607-1621.

48 Roach, T., \& Krieger-Liszkay, A. (2014). Regulation of photosynthetic electron transport and photoinhibition. Curr Protein Pept Sci. 15(4), 351-362.

49 Shikanai, T., \& Yamamoto, H. (2017). Contribution of cyclic and pseudo-cyclic electron transport to the formation of proton motive force in chloroplasts. Mol plant. 10(1), 20-29.

50 Parry, M. A., Keys, A. J., Madgwick, P. J., Carmo-Silva, A. E., \& Andralojc, P. J. (2008). Rubisco regulation: a role for inhibitors. J exp bot, 59(7), 1569-1580.

51 Poór, P., Borbély, P., Czékus, Z., Takács, Z., Ördög, A., Popović, B., \& Tari, I. (2019a). Comparison of changes in water status and photosynthetic parameters in wild type and abscisic acid-deficient sitiens mutant of tomato (Solanum lycopersicum cv. Rheinlands Ruhm) exposed to sublethal and lethal salt stress. Journal of Plant Physiol, 232, 130-140.

52 Kalaji, H. M., Schansker, G., Ladle, R. J., Goltsev, V., Bosa, K., Allakhverdiev, S. I., ... \& Elsheery, N. I. (2014). Frequently asked questions about in vivo chlorophyll fluorescence: practical issues. Photosynthesis research, 122(2), 121-158.

53 Kalaji, H. M., Schansker, G., Brestic, M., Bussotti, F., Calatayud, A., Ferroni, L., ... \& Losciale, P. (2017). Frequently asked questions about chlorophyll fluorescence, the sequel. Photosynthesis Research, 132(1), 13-66.

54 Niyogi, K. K., Li, X. P., Rosenberg, V., \& Jung, H. S. (2004). Is PsbS the site of non-photochemical quenching in photosynthesis? J exp bot, 56(411), 375-382.

55 Ikeuchi, M., Uebayashi, N., Sato, F., \& Endo, T. (2014). Physiological functions of PsbS-dependent and PsbS-independent NPQ under naturally fluctuating light conditions. Plant and Cell Physiology, 55(7), 1286-1295.

56 Braun, D. M., Wang, L., \& Ruan, Y. L. (2013). Understanding and manipulating sucrose phloem loading, unloading, metabolism, and signalling to enhance crop yield and food security. J exp bot, 65(7), 1713-1735.

57 Wingler, A., Lea, P. J., Quick, W. P., \& Leegood, R. C. (2000). Photorespiration: metabolic pathways and their role in stress protection. Philosophical Transactions of the Royal Society of London. Series B: Biological Sciences, 355(1402), 15171529.

58 Kangasjärvi, S., Neukermans, J., Li, S., Aro, E. M., \& Noctor, G. (2012). Photosynthesis, photorespiration, and light signalling in defence responses. J exp bot, 63(4), 1619-1636.

59 Kays, S.J., Pallas, Jr J.E., (1980) Inhibition of photosynthesis by ethylene. Nature 285(5759), 51

60 Taylor, G. E., \& Gunderson, C. A. (1986). The response of foliar gas exchange to exogenously applied ethylene. Plant Physiol. 82(3), 653-657.

61 Woodrow L, Grodzinski B, An Evaluation of the Effects of Ethylene on Carbon Assimilation in Lycopersicon esculentum Mill, J exp bot, Volume 40, Issue 3, March 1989, Pages 361-368,

62 Pallaghy, C. K., \& Raschke, K. (1972). No stomatal response to ethylene. Plant Physiol. 49(2), 275.

63 Gunderson, C. a, Taylor, G.E., 1991. Ethylene Directly Inhibits Foliar Gas Exchange in Glycine max. Plant Physiol. 95 , 
64 Zacarias, L., \& Reid, M. S. (1990). Role of growth regulators in the senescence of Arabidopsis thaliana leaves. Physiol Plant. 80(4), 549-554.

65 Grbić, V., \& Bleecker, A. B. (1995). Ethylene regulates the timing of leaf senescence in Arabidopsis. Plant J. 8(4), 595602.

66 Khan, N.A. (2004) An evaluation of the effects of exogenous ethephon, an ethylene releasing compound, on photosynthesis of mustard (Brassica juncea) cultivars that differ in photosynthetic capacity. BMC plant biol. 4(1), 1.

67 Song, X., She, X., Wang, J. (2012a) Inhibition of abscisic acid-induced stomatal closure by ethylene is related to the change of hydrogen peroxide levels in guard cells in broad bean. Australian J Bot. 59(8), 781.

68 Song, X.G., She, X.P., Wang, J. (2012b) Inhibition of darkness-induced stomatal closure by ethylene involves a removal of hydrogen peroxide from guard cells of Vicia faba. Russian J Plant Physiol. 59(3), 372.

69 Song, X. G., She, X. P., Wang, J., \& Sun, Y. C. (2011). Ethylene inhibits darkness-induced stomatal closure by scavenging nitric oxide in guard cells of Vicia faba. Funct Plant Biol. 38(10), 767-777.

70 Ge, X.M., Cai, H.L., Lei, X., Zhou, X., Yue, M., He, J.M. (2015) Heterotrimeric G protein mediates ethylene-induced stomatal closure via hydrogen peroxide synthesis in Arabidopsis. Plant J. 82(1), 138-150.

71 Wullschleger, S. D., Hanson, P. J., \& Gunderson, C. A. (1992). Assessing the influence of exogenous ethylene on electron transport and fluorescence quenching in leaves of Glycine max. Envir exp bot. 32(4), 449-455.

72 Xie, X. L., Xia, X. J., Kuang, S., Zhang, X. L., Yin, X. R., Yu, J. Q., \& Chen, K. S. (2017). A novel ethylene responsive factor CitERF13 plays a role in photosynthesis regulation. Plant Sci. 256, 112-119.

73 Bhattacharjee, S. (2012). The language of reactive oxygen species signaling in plants. J Bot., 2012.

74 Waszczak, C., Carmody, M., \& Kangasjärvi, J. (2018). Reactive oxygen species in plant signaling. Ann rev plant biol. 69 , 209-236.

75 Noctor, G., Reichheld, J. P., \& Foyer, C. H. (2018). ROS-related redox regulation and signaling in plants. In Seminars in Cell \& Developmental Biology (Vol. 80, pp. 3-12). Academic Press.

76 Valderrama, R., Corpas, F. J., Carreras, A., Fernández-Ocaña, A., Chaki, M., Luque, F., ... \& Barroso, J. B. (2007). Nitrosative stress in plants. Febs Letters, 581(3), 453-461.

77 Corpas, F., \& Palma, J. (2018). Assessing nitric oxide (NO) in higher plants: an outline. Nitrogen, 1(1), 12-20.

78 Desikan R., Griffiths R., Hancock J., Neill S. (2002): A new role for an old enzyme: nitrate reductase-mediated nitric oxide generation is required for abscisic acid-induced stomatal closure in Arabidopsis thaliana. Proc. Nat. Acad. Sci. USA. 99, 16314-16318.

79 Moreau M., Lindermayr C., Durner J. Klessig D.F. (2010): NO synthesis and signaling in plants-where do we stand? Physiol Plant. 138, 372-383.

80 Wang Y., Chen C., Loake J. G., Chu C. (2010a): Nitric Oxide: promoter or suppressor of programmed cell death? Prot cell. $1,133-142$.

81 Bright J., Desikan R., Hancock J.T., Weir S. I., Neill J. S., (2006): ABA-induced NO generation and stomatal closure in Arabidopsis are dependent on $\mathrm{H} 2 \mathrm{O} 2$ synthesis. Plant J. 45, 113-122.

82 Sang J., Jiang M., Lin F., Xu S., Zhang A., Tan M. (2008): Nitric oxide reduces hydrogen peroxide accumulation involved in water stress-induced subcellular anti-oxidant defense in maize plants. J. Integ. Plant. Biol. 50, 231-243.

83 Bellin D. Asai S., Delledonne M., Yoshioka H. (2013): Nitric Oxide as a Mediator for Defense Responses. Mol. PlantMicrobe Interact. 26, 271-277.

84 Kapoor, D., Singh, S., Kumar, V., Romero, R., Prasad, R., \& Singh, J. (2019). Antioxidant enzymes regulation in plants in reference to reactive oxygen species (ROS) and reactive nitrogen species (RNS). Plant Gene, 100182.

85 Alscher R.G., Erturk N., Heath L.S. (2002) Role of superoxide dismutases (SODs) in controlling oxidative stress in plants. $J$ exp bot. 53(372), 1331-1341.

86 Feng K., Yu J., Cheng Y., Ruan M., Wang R., Ye Q. és mtsai., (2016) The SOD gene family in tomato: identification, phylogenetic relationship and expression patterns. Fron. Plant. Sci. 30, 1279.

87 Kuo W., Huang C., Shih C., Jinn T. (2013) Cellular extract preparation for superoxide dismutase (SOD) activity assay. Bioprotocol. 3, 811 .

88 Podgórska A., Burian M., Szal B. (2017) Extra-Cellular but extra-ordinarily important for cells: Apoplastic reactive oxygen species metabolism. Front. Plant Sci. 8, 1353.

89 Bayer E.M., Bottrill A.R., Walshaw J., Vigouroux M., Naldrett M.J., Thomas C.L., és mtsai., (2006) 90 O’Brien J.A., Daudi A., Finch P., Butt V.S., Whitelegge J.P., Souda P., és mtsai., (2012) A peroxidase dependent apoplastic oxidative burst in cultured Arabidopsis cells functions in MAMP-elicited defense. Plant Physiol. 158, 2013-2027.

90 O’Brien J.A., Daudi A., Finch P., Butt V.S., Whitelegge J.P., Souda P., és mtsai., (2012) A peroxidase dependent apoplastic oxidative burst in cultured Arabidopsis cells functions in MAMP-elicited defense. Plant Physiol. 158, 2013-2027.

91 Mhamdi A., Queval G., Chaouch S., Vanderauwera S., Van Breusegem F., Noctor G. (2010) Catalase function in plants: a focus on Arabidopsis mutants as stress-mimic models. J exp bot. 61, 4194-4220.

92 Racchi M.L. (2013) Antioxidant defences in plants with attention to Prunus and Citrus spp. Antioxidants. 2: 340-369.

93 Najami N., Janda T., Barriah W., Kayam G., Tal M., Guy M., Volokita M. (2008) Ascorbate peroxidase gene family in tomato: Its identification and characterization. Mol. Genet. Genomics. 279, 171-182.

94 Panchuk I.I., Zentgraf U., Volkov R.A. (2005) Expression of the Apx gene family during leaf senescence of Arabidopsis thaliana. Planta. 222(5), 926-932.

95 Corpas, F. J., \& Barroso, J. B. (2013). Nitro-oxidative stress vs oxidative or nitrosative stress in higher plants. New Phytologist, 199(3), 633-635.

96 Lindermayr, C. (2018). Crosstalk between reactive oxygen species and nitric oxide in plants: key role of S-nitrosoglutathione reductase. Free Radical Bio Med. 122, 110-115.

97 Wang, H., Liang, X., Wan, Q., Wang, X., \& Bi, Y. (2009). Ethylene and nitric oxide are involved in maintaining ion homeostasis in Arabidopsis callus under salt stress. Planta, 230(2), 293-307. 
98 Poór, P., Borbély, P., Kovács, J., Papp, A., Szepesi, Á., Takács, Z., \& Tari, I. (2014). Opposite extremes in ethylene/nitric oxide ratio induce cell death in suspension culture and root apices of tomato exposed to salt stress. Acta Biol Hungarica. 65(4), 428-438.

99 Cui, M., Lin, Y., Zu, Y., Efferth, T., Li, D., Tang, Z. (2015) Ethylene increases accumulation of compatible solutes and decreases oxidative stress to improve plant tolerance to water stress in Arabidopsis. J Plant Biol, 58(3), 193-201.

100 Chen, H. J., Huang, C. S., Huang, G. J., Chow, T. J., \& Lin, Y. H. (2013). NADPH oxidase inhibitor diphenyleneiodonium and reduced glutathione mitigate ethephon-mediated leaf senescence, $\mathrm{H}_{2} \mathrm{O}_{2}$ elevation and senescence-associated gene expression in sweet potato (Ipomoea batatas). J Plant Physiol. 170(17), 1471-1483.

101 Steffens, B., \& Sauter, M. (2009). Epidermal cell death in rice is confined to cells with a distinct molecular identity and is mediated by ethylene and $\mathrm{H} 2 \mathrm{O} 2$ through an autoamplified signal pathway. Plant Cell. 21(1), 184-196.

102 Kim, Y. S., Kim, H. S., Lee, Y. H., Kim, M. S., Oh, H. W., Hahn, K. W., ... \& Jeon, J. H. (2008). Elevated H 2 O 2 production via overexpression of a chloroplastic Cu/ZnSOD gene of lily (Lilium oriental hybrid 'Marco Polo') triggers ethylene synthesis in transgenic potato. Plant cell rep. 27(6), 973-983.

103 Sewelam, N., Kazan, K., Thomas-Hall, S. R., Kidd, B. N., Manners, J. M., \& Schenk, P. M. (2013). Ethylene response factor 6 is a regulator of reactive oxygen species signaling in Arabidopsis. PloS one, 8(8), e70289.

104 Xia, X. J., Zhou, Y. H., Shi, K., Zhou, J., Foyer, C. H., \& Yu, J. Q. (2015). Interplay between reactive oxygen species and hormones in the control of plant development and stress tolerance. J exp bot. 66(10), 2839-2856.

105 Zhang, M., Smith, J. A. C., Harberd, N. P., \& Jiang, C. (2016). The regulatory roles of ethylene and reactive oxygen species (ROS) in plant salt stress responses. Plant Mol Biol. 91(6), 651-659.

106 Larkindale, J., \& Huang, B. (2004). Thermotolerance and antioxidant systems in Agrostis stolonifera: involvement of salicylic acid, abscisic acid, calcium, hydrogen peroxide, and ethylene. J Plant Physiol. 161(4), 405-413.

107 Kan, J., Che, J., Xie, H. Y., \& Jin, C. H. (2011). Effect of 1-methylcyclopropene on postharvest physiological changes of 'Zaohong'plum. Acta physiol plant. 33(5), 1669-1677.

108 Golemiec, E., Tokarz, K., Wielanek, M., \& Niewiadomska, E. (2014). A dissection of the effects of ethylene, H2O2 and high irradiance on antioxidants and several genes associated with stress and senescence in tobacco leaves. J Plant Physiol. 171(3-4), 269-275.

109 Kumar, G. and Knowles, N.R. (2003) Wound-induced superoxide production and PAL activity decline with potato tuber age and wound healing ability. Physiol Plant. 117(1), 108-117.

110 Lv, S. F., Jia, M. Z., Zhang, S. S., Han, S., \& Jiang, J. (2019). The dependence of leaf senescence on the balance between 1-aminocyclopropane-1-carboxylate acid synthase 1 (ACS 1)-catalysed ACC generation and nitric oxide-associated 1 (NOS 1)-dependent NO accumulation in Arabidopsis. Plant Biology.

111 Freschi, L. (2013). Nitric oxide and phytohormone interactions: current status and perspectives. Front Plant Sci. 4, 398.

112 Liu, G. H., Liu, J., Hou, L. X., Tang, J., \& Liu, X. (2009). NO may function in the downstream of Ca2+ in ethylene induced stomatal closure in Vicia faba L. J mol cell boil. 42(2), 145-155.

113 She, X., \& Song, X. (2012). Ethylene inhibits abscisic acid-induced stomatal closure in Vicia faba via reducing nitric oxide levels in guard cells. New Zealand J bot. 50(2), 203-216.

114 Gibbs, D. J., Isa, N. M., Movahedi, M., Lozano-Juste, J., Mendiondo, G. M., Berckhan, S., ... \& Bassel, G. W. (2014). Nitric oxide sensing in plants is mediated by proteolytic control of group VII ERF transcription factors. Mol Cell. 53(3), 369-379.

115 Novikova, G. V., Mur, L. A., Nosov, A. V., Fomenkov, A. A., Mironov, K. S., Mamaeva, A. S., ... \& Hall, M. A. (2017). Nitric oxide has a concentration-dependent effect on the cell cycle acting via EIN2 in Arabidopsis thaliana cultured cells. Front physiol 8, 142.

116 National Center for Biotechnology Information. PubChem Database. CID=535, https://pubchem.ncbi.nlm.nih.gov/compound/1-Aminocyclopropanecarboxylic-acid (accessed on July 22, 2019)

117 Peck, S.C., Pawlowski, K., Kende, H. (1998) Asymmetric responsiveness to ethylene mediates cell elongation ithe apical hook of peas. Plant Cell. 10(5), 713.

118 Nascimento, F.X., Rossi, M.J., Glick, B.R., Soto, M.J., 2018. Ethylene and (ACC) in Plant - Bact Interact. 9, 1-17.

119 Finlayson, S. A., Foster, K. R., \& Reid, D. M. (1991). Transport and Metabolism of 1-Aminocyclopropane-1-carboxylic Acid in Sunflower (Helianthus annuus L.) Seedlings. Plant Physiol. 96(4), 1360-1367.

120 Vanderstraeten, L., \& Straeten, D. Van Der. (2017). Accumulation and Transport of Acid ( ACC ) in Plants : Current Status, Considerations for Future Research and Agronomic Applications. Front plant sci 8, 1-18.

121 Munné-Bosch, S., López-Carbonell, M., Alegre, L., Van Onckelen, H.A. (2002) Effect of drought and high solar radiation on 1-aminocyclopropane-1-carboxylic acid and abscisic acid concentrations in Rosmarinus officinalis plants. Physiol Plant. 114(3), 380.

122 Grodzinski, B., Boesel, I., Horton, R.F. (1982) The effect of light intensity on the release of ethylene from leaves. $J$ exp bot 33(6), 1185-1193.

123Abeles FB, Heggestad HE (1973) Ethylene: an urban air pollutant. J Air Pollut Control Assoc 23, 517-521.

124 Dubois M, Van den Broeck L, Inzé D (2018) The pivotal role of ethylene in plant growth Trends Plant Sci 23, $311-323$.

125 Abeles FB. Morgan PW. Saltveit ME (1992) Regulation of ethylene production by internal, environmental and stress factors. In: Abeles FB, Morgan PW, Saltveit ME (eds) Ethylene in plant biology, 2nd edn. Academic Press, London, pp $54-262$

126 Toon GC, Blavier J-FL, Sung K (2018) Measurements of atmospheric ethene by solar absorption FTIR spectrometry. Atmos Chem Phys 18:5075-5088.

127 Else M, Hall KC, Arnold GM, Davies WJ, Jackson MB (1995) Export of abscisic acid, 1-aminocyclopropane-1-carboxylic acid, phosphate, and nitrate from roots to shoots of flooded tomato plants (accounting for effects of xylem sap flow rate on concentration and delivery). Plant Physiol 107:377-384 
128 Glick, B. R., Penrose, D. M., \& Li, J. (1998). A model for the lowering of plant ethylene concentrations by plant growthpromoting bacteria. J Theoret Biol. 190(1), 63-68.

129 Zaidi A, Khan MS, Ahmad E, Saif S, Rizvi A, Shadid M (2016) Growth stimulation and management of diseases of ornamental plants using phosphate solubilizing microorganisms: current perspective. Acta Physiol Plant 38, 117.

130 Edelman, N. F., \& Jones, M. L. (2014). Evaluating ethylene sensitivity within the family Solanaceae at different developmental stages. Hort Sci. 49(5), 628-636.

131 Mensuali-Sodi, A., Panizza, M., Tognoni, F. (1995) Endogenous ethylene requirement for adventitious root induction and growth in tomato cotyledons and lavandin microcuttings in vitro. Plant Growth Regul. 17(3), 205.

132 De Cnodder, T., Vissenberg, K., Van Der Straeten, D., Verbelen, J.P. (2005) Regulation of cell length in theArabidopsis thaliana root by the ethylene precursor 1-aminocyclopropane- 1-carboxylic acid: a matter of apoplastic reactions. New Phytologist. 168(3), 541.

133 Leblanc, A., Renault, H., Lecourt, J., Etienne, P., Deleu, C., \& Le Deunff, E. (2008). Elongation Changes of Exploratory and Root Hair Systems Induced by Aminocyclopropane Carboxylic Acid and Aminoethoxyvinylglycine Affect Nitrate Uptake and BnNrt2.1 and BnNrt1.1 Transporter Gene Expression in Oilseed Rape. Plant Physiol. 146(4), 1928-1940.

134 Alarcon, M.V., Lloret, P.G., Iglesias, D.J., Talon, M., Salguero, J. (2009) Response of maize seedling roots to changing ethylene concentrations. Russian J Plant Physiol, 56(4), 488.

135 Calvo-Polanco, M., Ibort, P., Molina, S., Ruiz-Lozano, J. M., Zamarreño, A. M., García-Mina, J. M., \& Aroca, R. (2017). Ethylene sensitivity and relative air humidity regulate root hydraulic properties in tomato plants. Planta, 246(5), 987-997.

136 Fuhrer, J. (1985). Production and Release of Ethylene from 1-aminocyclopropane-1-carboxylic Acid in Lemna minor L. in the Dark and at Different Carbon Dioxide Compensation Concentrations. J Plant Physiol, 117(4), 307-317.

137 Yoon GM, Kieber JJ (2013) 1-Aminocyclopropane-1-carboxylic acid as a signalling molecule in plants. AoB Plants 5, plt017.

138 Xu S-L, Rahman A, Baskin TL, Kieber JJ (2008) Two leucine-rich repeat receptor kinases mediate signalling, linking cell wall biosynthesis and ACC synthase in Arabidopsis. Plant Cell 20:3065-3079

139 Tsang DL, Edmond C, Harrington JL, Nühse TS (2011) Cell wall integrity controls root elongation via a general 1 aminocyclopropane-1-carboxylic acid-dependent pathway. Plant Physiol 156:596-604

140 Yin, J., Zhang, X., Zhang, G., Wen, Y., Liang, G., \& Chen, X. (2019). Aminocyclopropane-1-carboxylic acid is a key regulator of guard mother cell terminal division in Arabidopsis thaliana. J exp bot, 70(3), 963-972.

141 Pessarakli M., Szabolcs I. (1999): Soil Salinity and Sodicity as Particular Plant/Crop Stress Factors. In: Pessarakli M.(Ed.): Handbook of plant and crop stress. Second edition. Marcel Dekker. New York. 1-15.

142 Hasegawa PM, Bressan RA, Zhu JK and Bohnert HJ (2000) Plant cellular and molecular responses to high salinity. Annu Rev Plant Phys 51, 463-499.

143 Munns, R., Tester, M., 2008. Mechanisms of salinity tolerance. Annu. Rev. Plant Biol. 59, 651-681.

144 FAO. 2005. Global Network on Integrated Soil Management for Sustainable Use of Salt-affected Soils. Rome, Italy: FAO Land and Plant Nutrition Management Service. http://www.fao.org/ag/agl/agll/spush

145 FAO (2008) FAO Land and Plant Nutrition Management Service. http://www.fao.org/ag/agl/agll/spush [Verified 24 May 2010]

146 Kaleem, F., Shabir, G., Aslam, K., Rasul, S., Manzoor, H., Shah, S. M., \& Khan, A. R. (2018). An Overview of the Genetics of Plant Response to Salt Stress: Present Status and the Way Forward. Applied Biochem Biotech. 186(2), 306-334.

147 Taiz L., Zeiger E. (2006) Plant Physiol. Fourth edition. Sunderland. Massachusetts.

148 Németh T. (2005): Talajvédelem: Országos Talajvédelmi Stratégia tudományos háttere. Bp. Környezetvédelmi és Vízügyi Minisztérium.

149 Yadav, S., Irfan, M., Ahmad, A., \& Hayat, S. (2011). Causes of salinity and plant manifestations to salt stress: a review. $J$ Environ Biol. 32(5), 667.

150 Isayenkov V.S. (2012):Physiological and Molecular Aspects of Salt Stress in Plants. Cytology and Genetics. 46:302-318.

151 Poór P. (2013): Sóstressz és szalicilsav indukálta élettani folyamatok összehasonlító vizsgálata paradicsomban: akklimatizáció vagy programozott sejthalál. Ph.D. Thesis. Biológia doktori iskola, 2013. Szeged.

152 Park, H. J., Kim, W.-Y., \& Yun, D.-J. (2016). A New Insight of Salt Stress Signaling in Plant. Molecules and Cells, 39(6), 447-459.

153 Evangelou P.V., McDonald Jr. L.M. (1999): Influence of Sodium on Soils of Humid Regions. In: Pessarakli M.(Ed.): Handbook of plant and crop stress. Second edition. Marcel Dekker. New York. 17-50.

154 García-Sanchez F., Jofon J., Carvajal M., Syvertsen J.P. (2002): Gas exchange, chlorophyll and nutrient contents in relation to $\mathrm{Na}+$ and $\mathrm{Cl}-$ accumulation in 'Sunburst' mandarin grafted on different rootstocks. Plant Sci. 162, 705-712.

155 Munns R. (2002): Comparative physiology of salt and water stress. Plant Cell Environ. 25, 239-250.

156 Isayenkov, S. V., Maathuis, F.J.M., 2019. Plant Salinity Stress: Many Unanswered Questions Remain. Front. Plant Sci.

157 Speer M., Kaiser W.M. (1991): Ion relations of symplastic and apoplastic space in leaves from Spinacia oleracea L. and Pisum sativum L. under salinity. Plant Physiol. 97, 990-997.

158 Shabala S. (2009): Salinity and programmed cell death: unravelling mechanisms for ion specific signalling. J. Exp. Bot. 60, 709-712.

159 Cuin, T. A., Miller, A. J., Laurie, S. A., \& Leigh, R. A. (2003). Potassium activities in cell compartments of salt-grown barley leaves. J exp bot, 54(383), 657-661.,

160 Cuin, T. A., Betts, S. A., Chalmandrier, R., \& Shabala, S. (2008). A root's ability to retain K+ correlates with salt tolerance in wheat. $J$ exp bot, 59(10), 2697-2706.

161 Berthomieu, P., Conéjéro, G., Nublat, A., Brackenbury, W. J., Lambert, C., Savio, C., ... \& Gosti, F. (2003). Functional analysis of AtHKT1 in Arabidopsis shows that $\mathrm{Na}+$ recirculation by the phloem is crucial for salt tolerance. The EMBO journal, 22(9), 2004-2014. 
162 Stępień P., Kłobus G. (2006): Water relations and photosynthesis in Cucumis sativus L. leaves under salt stress. Biol Plant. 50, 610-616.

163 Bose, J., Munns, R., Shabala, S., Gilliham, M., Pogson, B., \& Tyerman, S. D. (2017). Chloroplast function and ion regulation in plants growing on saline soils: Lessons from halophytes. $J$ exp bot, 68(12), 3129-3143.

164 Noreen Z., Ashraf M., Akram A.N. (2012): Salt-induced regulation of photosynthetic capacity and ion accumulation in some genetically diverse cultivars of radish (Raphanus sativus L.). J. App. Bot. Food Q. 85:91-96.

165 Juan M., Rivero R. M., Romero L., Ruiz J. M. (2005): Evaluation of some nutritional and biochemical indicators in selecting salt-resistant tomato cultivars. Environ. Exp. Bot. 54, 193-201.

166 Mehta P., Jajoo A., Mathur S., Bharti S. (2010): Chlorophyll a fluorescence study revealing effects of high salt stress on Photosystem II in wheat leaves. Plant. Physiol. Biochem. 48, 16-20.

167 Jiang, C., Belfield, E. J., Mithani, A., Visscher, A., Ragoussis, J., Mott, R., ... Harberd, N. P. (2012). ROS-mediated vascular homeostatic control of root-to-shoot soil Na delivery in Arabidopsis. EMBO Journal, 31(22), 4359-4370.

168 Torre-González, A., Navarro-León, E., Albacete, A., Blasco, B., \& Ruiz, J. M. (2017). Study of phytohormone profile and oxidative metabolism as key process to identification of salinity response in tomato commercial genotypes. J Plant Physiol, 216(March), 164-173.

169 Corpas, F. J., Leterrier, M., Valderrama, R., Airaki, M., Chaki, M., Palma, J. M., \& Barroso, J. B. (2011). Nitric oxide imbalance provokes a nitrosative response in plants under abiotic stress. Plant Science, 181(5), 604-611.

170 Xie Y., Ling T., Han Y., Liu K., Zheng Q., Huang L., Yuan X., He Z., Hu B., Fang L., Shen Z., Yang Q., Shen W. (2008): Carbon monoxide enhances salt tolerance by nitric oxide-mediated maintenance of ion homeostasis and up-regulation of antioxidant defence in wheat seedling roots. Plant Cell Environ. 31, 1864-188.

171 Xu J., Yin H., Yang L., Xie Z.,Liu X. (2011): Differential salt tolerance in seedlings derived from dimorphic seeds of Atriplex centralasiatica: from physiology to molecular analysis. Planta. 233, 859-871.

172 Liu Y., Wu R., Wan Q., Xie G., Bi Y. (2007): Glucose-6-phosphate dehydrogenase plays a pivotal role in nitric oxideinvolved defense against oxidative stress under salt stress in red kidney bean roots. Plant Cell Physiol. 48, 511-522.

173 Charrier A., Lelièvre E., Limami A.M., Planchet E. (2013): Medicago truncatula stress associated protein 1 gene (MtSAPI) overexpression confers tolerance to abiotic stress and impacts proline accumulation in trans genic tobacco. J. Plant Physiol. 170, 874-877.

174 Delledonne M., Zeier J., Marocco A., Lamb C. (2001): Signal interactions between nitric oxide and reactive oxygen intermediates in the plant hypersensitive disease resistance response. Proc. Natl. Acad. Sci. USA 98, 13454-13459.

175 Corpas, F. J., Carreras, A., Valderrama, R., Chaki, M., Palma, J. M., del Río, L. A., \& Barroso, J. B. (2007). Reactive nitrogen species and nitrosative stress in plants. Plant Stress, 1, 37-41.

176 Zeng C.L., Liu L., Wang B.R.,Wu M.X., Zhou Y. (2011): Physiological effects of exogenous nitric oxide on Brassica juncea seedlings under $\mathrm{NaCl}$ stress. Biol. Plantarum. 55, 45-348.

177 Khan N., Siddiqui M., Mohammad M.H.F., Naeem M. (2012): Interactive role of nitric oxide and calcium chloride in enhancing tolerance to salt stress. Nitric Oxide. 27, 210-218.

178 Zhang Y, Wang L, Liu Y, Zhang Q, Wei Q and Zhang W (2006) Nitric oxide enhances salt tolerance in maize seedlings through increasing activities of proton-pump and $\mathrm{Na}+/ \mathrm{H}+$ antiport in the tonoplast. Planta 224, 545-55

179 Camejo D, Romero-Puertas Mdel C, Rodríguez-Serrano M, Sandalio LM, Lázaro JJ, Jiménez A and Sevilla F (2013) Salinity-induced changes in S-nitrosylation of pea mitochondrial proteins. J Proteomics 79,87-99.

180 Andronis EA and Roubelakis-Angelakis KA (2010) Short-term salinity stress in tobacco plants leads to the onset of animallike PCD hallmarks in planta in contrast to long-term stress. Planta 231,437-448

181 Huh GH, Damsz B, Matsumoto TK, Reddy MP, Rus AM, Ibeas JI, Narasimhan ML, Bressan RA and Hasegawa PM (2002) Salt causes ion disequilibrium-induced programmed cell death in yeast and plants. Plant J 29,649-659

182 Affenzeller MJ, Darehshouri A, Andosch A, Lütz C and Lütz-Meindl U (2009) Salt stress-induced cell death in the unicellular green alga Micrasterias denticulata. J Exp Bot 60,939-954.

183 Levitt J (1972) Responses of plants to environmental stresses. New York, Academic Press ISBN 0-12-445560-3 p569-665.

184 Whitlow TH, Bassuk NL, Ranney TG and Reichert DL (1992) An improved method for using electrolyte leakage to assess membrane competence in plant tissues. Plant Physiol 98,198-205.

185 Demidchik V, Cuin TA, Svistunenko D, Smith SJ, Miller AJ, Shabala S, Sokolik A and Yurin V (2010) Arabidopsis root $\mathrm{K}+$-efflux conductance activated by hydroxyl radicals, single-channel properties genetic basis and involvement in stressinduced cell death. J Cell Sci 123,1468-1479.

186 Fahad, S., Hussain, S., Matloob, A., \& Ahmed, F. (2015). Phytohormones and plant responses to salinity stress, a review. Plant growth regul. 75(2), 391-404.

187 Szepesi, Á., Csiszár, J., Gémes, K., Horváth, E., Horváth, F., Simon, M. L., \& Tari, I. (2009). Salicylic acid improves acclimation to salt stress by stimulating abscisic aldehyde oxidase activity and abscisic acid accumulation, and increases $\mathrm{Na}+$ content in leaves without toxicity symptoms in Solanum lycopersicum L. J Plant Physiol, 166(9), 914-925.

188 Poór, P., Szopkó, D., \& Tari, I. (2012). Ionic homeostasis disturbance is involved in tomato cell death induced by $\mathrm{NaCl}$ and salicylic acid. In Vitro Cellular and Developmental Biology - Plant, 48(3), 377-382.

189 Poór, P., \& Tari, I. (2011). Ethylene-regulated reactive oxygen species and nitric oxide under salt stress in tomato cell suspension culture. Acta Biol Szegediensis. 55(1), 143-146. Retrieved from http,//www.scopus.com/inward/record.url?eid=2-s2.0 83255186950\&partnerID=40\&md5=e10c96644cfe766c6104027359f3bc72

190 Wi SJ, Jang SJ, Park KY (2010) Inhibition of biphasic ethylene production enhances tolerance to abiotic stress by reducing the accumulation of reactive oxygen species in Nicotiana tabacum. Mol Cells 30,37-49.

191 Jung J-Y, Shin R, Schachtman DP (2009) Ethylene mediates response and tolerance to potassium deprivation in Arabidopsis. Plant Cell 21,607-621

192 Schachtman DP (2015) The role of ethylene in plant responses to $\mathrm{K}^{+}$deficiency. Front Plant Sci 6:1153. 
193 Ryu, H., \& Cho, Y. G. (2015). Plant hormones in salt stress tolerance. J Plant Biol, 58(3), 147-155.

194 Trivellini, A., Lucchesini, M., Ferrante, A., Carmassi, G., Scatena, G., Vernieri, P., \& Mensuali-Sodi, A. (2016). Survive or die? A molecular insight into salt-dependant signaling network. Environ Exp Botany. 132, 140-153.

195 Yang, Y., \& Guo, Y. (2018). Unraveling salt stress signaling in plants. Journal of Integrative Plant Biology, 60(9), 796804.

196 Yang, L., Zu, Y. G., \& Tang, Z. H. (2013). Ethylene improves Arabidopsis salt tolerance mainly via retaining K+in shoots and roots rather than decreasing tissue $\mathrm{Na}^{+}$content. Environ Exp Bot, 86, 60-69.

197 Lin, Y., Yang, L., Paul, M., Zu, Y., \& Tang, Z. (2013). Ethylene promotes germination of Arabidopsis seed under salinity by decreasing reactive oxygen species: Evidence for the involvement of nitric oxide simulated by sodium nitroprusside. Plant Physiol Biochem. 73, 211-218.

198 Sehar, Z., Masood, A., \& Khan, N. A. (2019). Nitric oxide reverses glucose-mediated photosynthetic repression in wheat (Triticum aestivum L.) under salt stress. Environ Exp Bot. 161, 277-289.

199 Li, X., Pan, Y., Chang, B., Wang, Y., \& Tang, Z. (2016). NO promotes seed germination and seedling growth under high salt may depend on EIN3 protein in Arabidopsis. Front plant sci. 6, 1203.

200 Cao, W.-H., Liu, J., He, X.-J., Mu, R.-L., Zhou, H.-L., Chen, S.-Y., \& Zhang, J.-S. (2007). Modulation of Ethylene Responses Affects Plant Salt-Stress Responses. Plant Physiol, 143(2), 707-719.

201 Ghanem, M. E., Albacete, A., Martínez-Andújar, C., Acosta, M., Romero-Aranda, R., Dodd, I. C., ... Pérez-Alfocea, F. (2008). Hormonal changes during salinity-induced leaf senescence in tomato (Solanum lycopersicum L.). J exp bot, 59(11), 3039-3050.

202 Pérez-Alfocea, F., Ghanem, M.E., Gómez-Cadenas, A., Dodd, I.C., 2011. Omics of Root-to-Shoot Signaling Under Salt Stress and Water Deficit. Omi. A J. Integr. Biol. 15, 893-901.

203 Hussain, S., Zhong, C., Bai, Z., Cao, X., Zhu, L., Hussain, A., ... Jin, Q. (2018). Effects of 1-Methylcyclopropene on Rice Growth Characteristics and Superior and Inferior Spikelet Development Under Salt Stress. J Plant Growth Regul. 37(4), $1368-1384$.

204 Abogadallah, G. M., Nada, R. M., Malinowski, R., \& Quick, P. (2011). Overexpression of HARDY, an AP2/ERF gene from Arabidopsis, improves drought and salt tolerance by reducing transpiration and sodium uptake in transgenic Trifolium alexandrinum L. Planta, 233(6), 1265-1276.

205 Poór, P., Gémes, K., Horváth, F., Szepesi, Á., Simon, M. L., \& Tari, I. (2011). Salicylic acid treatment via the rooting medium interferes with stomatal response, $\mathrm{CO} 2$ fixation rate and carbohydrate metabolism in tomato, and decreases harmful effects of subsequent salt stress. Plant Biol. Vol. 13, pp. 105-114.

206 Pető, A., Lehotai, N., Feigl, G., Tugyi, N., Ördöog, A., Gémes, K., és mtsai., 2013. Nitric oxide contributes to copper tolerance by influencing ROS metabolism in Arabidopsis. Plant Cell Rep. 32, 1913-1923

207 Lehotai, N., Pető, A., Bajkán, Sz, Erdei, L., Tari, I., Kolbert, Zs, 2011. In vivo and in situ visualization of early physiological events induced by heavy metals in pea root meristem. Acta Physiol. Plant 33, 2199-2207.

208 Takács, Z., Poór, P., Szepesi, Á., \& Tari, I. (2017). In vivo inhibition of polyamine oxidase by a spermine analogue, MDL72527, in tomato exposed to sublethal and lethal salt stress. Functi Plant Biol. 44(5), 480-492.

209 Bournonville GCF, Diaz-Ricci JC (2010) Quantitative determination of superoxide in plant leaves using a modified NBT staining method. Phytochem Anal 22:268-271

210 Sims, D. A., \& Gamon, J. A. (2002). Relationships between leaf pigment content and spectral reflectance across a wide range of species, leaf structures and developmental stages. Remote sensing of environment, 81(2-3), 337-354.

211 Klughammer, C., \& Schreiber, U. (2008). Complementary PS II quantum yields calculated from simple fluorescence parameters measured by PAM fluorometry and the Saturation Pulse method. PAM App Notes, 1(1), 27-35.

212 Lei, Y., Zheng, Y., Dai, K., Duan, B., \& Cai, Z. (2014). Different responses of photosystem I and photosystem II in three tropical oilseed crops exposed to chilling stress and subsequent recovery. Trees, 28(3), 923-933.

213 Zhang, G., Liu, Y., Ni, Y., Meng, Z., Lu, T., \& Li, T. (2014). Exogenous calcium alleviates low night temperature stress on the photosynthetic apparatus of tomato leaves. PLoS ONE, 9(5), 1-12.

214 Dubois, M., Gilles, K. A., Hamilton, J. K., Rebers, P. T., \& Smith, F. (1956). Colorimetric method for determination of sugars and related substances. Anal chem. 28(3), 350-356.

215 Tari, I., Guóth, A., Benyó, D., Kovács, J., Poór, P., \& Wodala, B. (2010). The roles of ABA, reactive oxygen species and nitric oxide in root growth during osmotic stress in wheat: comparison of a tolerant and a sensitive variety. Acta Biol Hungarica, 61(Supplement 1), 189-196.

216 Poór, P., Borbély, P. G., Bódi, N., Bagyánszki, M., \& Görgényi Miklósné Tari, I. (2019b). Effects of salicylic acid on photosynthetic activity and chloroplast morphology under light and prolonged darkness. Photosynthetica, 57, 367-376.

217 Laurentin, A., \& Edwards, C. A. (2003). A microtiter modification of the anthrone-sulfuric acid colorimetric assay for glucose-based carbohydrates. Anal biochem. 315(1), 143-145.

218 Bradford, M. M. (1976). A rapid and sensitive method for the quantitation of microgram quantities of protein utilizing the principle of protein-dye binding. Anal biochem. 72(1-2), 248-254.

219 Rossano, R., Larocca, M., \& Riccio, P. (2011). 2-D zymographic analysis of Broccoli (Brassica oleracea L. var. Italica) florets proteases: follow up of cysteine protease isotypes in the course of post-harvest senescence. J Plant Physiol, 168(13), 1517-1525.

220 Takács, Z., Poór, P., Borbély, P., Czékus, Z., Szalai, G., \& Tari, I. (2018). H2O2 homeostasis in wild-type and ethyleneinsensitive Never ripe tomato in response to salicylic acid treatment in normal photoperiod and in prolonged darkness. Plant Physiol and biochem. 126, 74-85.

221 Horváth, E., Brunner, S., Bela, K., Papdi, C., Szabados, L., Tari, I., \& Csiszár, J. (2015). Exogenous salicylic acid-triggered changes in the glutathione transferases and peroxidases are key factors in the successful salt stress acclimation of Arabidopsis thaliana. Funct Plant Biol. 42(12), 1129-1140. 
222 Gallé, Á. (2010). Búzafajták ozmotikus-és szárazságstressz alatti akklimatizációja, a glutation transzferázok szerepe a stresszválaszban (Doctoral dissertation, szte).

223 Rozen S., Skaletsky H.J. (2000) Primer3 on the WWW for general users and for biologist programmers. In: Krawetz S., Misener S. (szerk.) Bioinformatics Methods and Protocols: Methods in Molecular Biology. Humana Press, Totowa, NJ, pp 365-386.

224 Livak K.J., Schmittgen T.D. (2001) Analysis of relative gene expression data using real-time quantitative PCR and the $2-\Delta \Delta \mathrm{Ct}$ method. Methods. 25: 402-408.

225 Lovdal T., Lillo C. (2009) Reference gene selection for quantitative real-time PCR normalization in tomato subjected to nitrogen, cold, and light stress. Anal Biochem. 387: 238-242.

226 Leclerq J., Adams-Phillips L.C., Zegzouti H., Jones B., Latche A., Giovanni J.J., Pech J.C., Bouzayen M. (2002) LeCTR1, a tomato CTR1-like gene, demonstrates ethylene signaling ability in Arabidopsis and novel expression patterns in tomato. Plant Physiol. 130: 1132-1142.

227 Kubis, S.E., Castilho, A.M.M.F., Vershinin, A.V., Heslop-Harrison, J.S., 2003. Retroelements, transposons and methylation statusin the genome of oil palm (Elaeis guineensis) and the relationship to somaclonal variation. Plant Mol. Biol. 52, 69-79.

228 Wang T-W, Arteca RN (1992) Effects of low $\mathrm{O}_{2}$ root stress on ethylene biosynthesis in tomato plants (Lycopersicon esculentum Mill cv Heinz 1350). Plant Physiol 98:97-100

229 Beyer Jr, E. M., \& Morgan, P. W. (1970). A method for determining the concentration of ethylene in the gas phase of vegetative plant tissues. Plant Physiol, 46(2), 352.

230 Schierle, J., \& Schwark, A. (1988). Asymmetric synthesis and concentrations of ethylene in the hypocotyl hook of Phaseolus vulgaris. J Plant Physiol, 133(3), 325-331.

231 Trujillo-Moya C, Gisbert C (2012) The influence of ethylene and ethylene modulators on shoot organogenesis in tomato. Plant Cell Tiss Org Cult 1:11-41

232 Staal M, De Cnodder T, Simon D, Vandenbussche F, Van der Straeten D, Verbelen J-P, Elzenga T, Vissenberg K (2011) Apoplastic alkalinization is instrumental for the inhibition of cell elongation in the Arabidopsis root by the ethylene precursor 1-aminocyclopropane-1-carboxylic acid. Plant Physiol 155, 2049-2055

233 Saranga Y, Zamir D, Marani A, Rudich J (1993) Breeding tomatoes for salt tolerance, variations in ion concentrations associated with response to salinity. J Am Soc Hort Sci 118, 405-408

234 Kocsy G, Tari I, Vanková R, Zechmann B, Gulyás Z, Poór P, Galiba G (2013) Redox control of plant growth and development. Plant Sci 211, 77-91

235 Ashley MK, Grant M, Grabov A (2005) Plant responses to potassium deficiencies: a role for potassium transport proteins. $J$ Exp Bot 57, 425-436

236 Demidchik D (2014) Mechanisms and physiological roles of $\mathrm{K}^{+}$efflux from root cells. J Plant Physiol 171, 696-707

237 Shabala S, Pottosin I (2014) Regulation of potassium transport in plants under hostile conditions: implications for abiotic and biotic stress tolerance. Physiol Plant 151, 257-279

238 Woodrow L, Thompson RG, Grodzinski B (1988) Effects of ethylene on photosynthesis and partitioning in tomato, Lycopersicon esculentum Mill. J Exp Bot 39, 667-684

239 Qin, L., He, J., Lee, S.K., Dodd, I.C., 2007. An assessment of the role of ethylene in mediating lettuce (Lactuca sativa) root growth at high temperatures. J. Exp. Bot. 58, 3017-3024.

240 Iqbal N, Nazar R, Syeed S, Masood A, Khan NA (2011) Exogenously-sourced ethylene increases stomatal conductance, photosynthesis, and growth under optimal and deficient nitrogen fertilization in mustard. J Exp Bot 62:4955-4963

241 Johnson NG (2011) Physiology of PSI cyclic electron transport in higher plants. Biochim Biophys Acta 1807:384-389

242 Krause GH, Weis E (1991) Chlorophyll fluorescence and photosynthesis. the basics. Ann Rev Plant Physiol Plant Mol Biol 42:313-349

243 Miyake C, Miyata M, Shinzaki Y, Tomizawa K (2005) CO2 response of cyclic electron flow around PSI (CEF-PSI) in tobacco leaves - relative electron fluxes through PSI and PSII determine the magnitude of non-photochemical quenching (NPQ) of Chl fluorescence. Plant Cell Physiol. 46, 629-637

244 Keunen E, Peshev D, Vangronsveld J, Van Den Ende W, Cuypers A (2013) Plant sugars are crucial players in the oxidative challenge during abiotic stress: extending the traditional concept. Plant Cell Environ 36, 1242-1255

245 Nishizawa A, Yabuta Y, Shigeoka S (2008) Galactinol and raffinose constitute a novel function to protect plants from oxidative damage. Plant Physiol 147, 1251-1263

246 Peshev D, Van den Ende W (2013) Sugars as antioxidants in plants. In: Tuteja N, Gill SS (eds) Crop improvement under adverse conditions. Springer, Berlin, pp 285-308

247 Poór, P., Kovács, J., Szopkó, D., Tari, I., 2013. Ethylene signaling in salt stress- and salicylic acid-induced programmed cell death in tomato suspension cells. Protoplasma 250, 273-284.

248 Kalemba, E.M., Pukacka, S., 2014. Carbonylated proteins accumulated as vitalitydecreases during long-term storage of beech (Fagus sylvatica L.) seeds. Trees 28, 503-515.

249 Petrov, V., Hille, J., Mueller-Roeber, B., Gechev, T.S., 2015. ROS-mediated abiotic stress-induced programmed cell death in plants. Front. Plant Sci. 6, 69.

250 Monteiro, C.C., Carvalho, R.F., Grat ao, P.L., Carvalho, G., Tezotto, T., Medici, L.O., Peres, L.E.P., Azevedo, R.A., 2011 Biochemical responses of the ethylene insensitive Never ripe tomato mutant subjected to cadmium and sodium stresses. Environ. Exp. Bot. 71, 306-320.

251 Arasimowicz-Jelonek, M., Floryszak-Wieczorek, J., Deckert, J., Rucińska-Sobkowiak, R., Gzyl, J., Pawlak-Sprada, S., et al., 2012. Nitric oxide implication in cadmium-induced programmed cell death in roots and signaling response of yellow lupine plants. Plant Physiol. Biochem. 58, 124-134.

252 Chmielowska-Bąk, J., Gzyl, J., Rucińska-Sobkowiak, R., Arasimowicz-Jelonek, M., Deckert, J., 2014. The new insights into cadmium sensing. Front. Plant Sci. 5, 245. 
253 Byczkowska, A., Kunikowska, A., Kaźmierczak, A., 2013. Determination of ACCinduced cell-programmed death in roots of Vicia faba ssp. minor seedlings by acridine orange and ethidium bromide staining. Protoplasma 250, 121-128.

254 Yakimova, E.T., Kapchina-Toteva, V.M., Laarhoven, L.J., Harren, F.M., Woltering, E.J., 2006. Involvement of ethylene and lipid signalling in cadmium-induced programmed cell death in tomato suspension cells. Plant Physiol. Biochem. 44, 581-589.

255 Cervantes, E., Rodríguez, A., Nicolás, G., 1994. Ethylene regulates the expression of a cysteine proteinase gene during germination of chickpea (Cicer arietinum L.). Plant Mol. Biol. 25, 207-215.

256 Jones, M.L., 2004. Changes in gene expression during senescence. In: Nood_en, L.D. (Ed.), Plant Cell Death Processes. Academic Press, San Diego California, pp. 51-67.

257 Jones, M.L., Chaffin, G.S., Eason, J.R., Clark, D.G., 2005. Ethylene-sensitivity regulates proteolytic activity and cysteine protease gene expression in petunia corollas. J. Exp. Bot. 56, 2733-2744.

258 Ye, Y., Li, Z., Xing, D., 2013. Nitric oxide promotes MPK6-mediated caspase-3-like activation in cadmium-induced Arabidopsis thaliana programmed cell death. Plant Cell Environ. 36, 1-15.

259 Kim, Y., Wang, M., Bai, Y., Zeng, Z., Guo, F., Han, N., et al., 2014. Bcl-2 suppresses activation of VPEs by inhibiting cytosolic $\mathrm{Ca}^{2+}$ level with elevated Kţ efflux in NaCl-induced PCD in rice. Plant Physiol. Biochem. 80, 168-175.

260 Rodríguez-Serrano, M., Romero-Puertas, M.C., Zabalza, A.N.A., Corpas, F.J., Gómez, M., Del Rio, L.A., Sandalio, L.M., 2006. Cadmium effect on oxidative metabolism of pea (Pisum sativum L.) roots. Imaging of reactive oxygen species and nitric oxide accumulation in vivo. Plant. Cell Environ. 29, 1532-1544.

261 Albacete, A., Ghanem, M. E., Martínez-Andújar, C., Acosta, M., Sánchez-Bravo, J., Martínez, V., et al. \& Pérez-Alfocea, F. (2008). Hormonal changes in relation to biomass partitioning and shoot growth impairment in salinized tomato (Solanum lycopersicum L.) plants. J exp bot, 59(15), 4119-4131.

262 Ijaz, B., Formentin, E., Ronci, B., Locato, V., Barizza, E., Hyder, M.Z., Schiavo, F. Lo, Yasmin, T., 2019. Salt tolerance in indica rice cell cultures depends on a fine tuning of ROS signalling and homeostasis. PLoS One 14, 1-27.

263 Carvalho, R.F., Aidar, S.T., Azevedo, R.A., Dodd, I.C., Peres, L.E.P., 2011. Enhanced transpiration rate in the high pigment 1 tomato mutant and its physiological significance Plant Biol. 13(3), 546-550..

264 Takemura, T., Hanagata, N., Dubinsky, Z., Karube, I., 2002. Molecular characterization and response to salt stress of mRNAs encoding cytosolic $\mathrm{Cu} / \mathrm{Zn}$ superoxide dismutase and catalase from Bruguiera gymnorrhiza. Trees - Struct. Funct. $16,94-99$.

265 Demir, Y., Oztürk, L., 2004. Influence of ethephon and 2,5-norbornadiene on antioxidative enzymes and proline content in salt-stressed spinach leaves. Biol. Plant. 47, 609-612.

266 Peng, J., Li, Z., Wen, X., Li, W., Shi, H., Yang, L., Zhu, H., Guo, H., 2014. Salt-Induced Stabilization of EIN3/EIL1 Confers Salinity Tolerance by Deterring ROS Accumulation in Arabidopsis. PLoS Genet. 10.

267 Wang, Q., Dodd, I.C., Belimov, A.A., Jiang, F., 2016. Rhizosphere bacteria containing 1-aminocyclopropane-1carboxylate deaminase increase growth and photosynthesis of pea plants under salt stress by limiting $\mathrm{Na}^{+}$accumulation. Funct. Plant Biol. 43, 161-172.

268 Holzmeister, C., Gaupels, F., Geerlof, A., Sarioglu, H., Sattler, M., Durner, J., Lindermayr, C., 2015. Differential inhibition of Arabidopsis superoxide dismutases by peroxynitrite-mediated tyrosine nitration. J. Exp. Bot. 66, 989-999.

269 Dugas, D. V., Bartel, B., 2008. Sucrose induction of Arabidopsis miR398 represses two Cu/Zn superoxide dismutases. Plant Mol. Biol. 67, 403-417.

270 Gharsallah, C., Fakhfakh, H., Grubb, D., Gorsane, F., 2016. Effect of salt stress on ion concentration, proline content, antioxidant enzyme activities and gene expression in tomato cultivars. AoB Plants 8.

271 Martí, M.C., Florez-Sarasa, I., Camejo, D., Ribas-Carbó, M., Lázaro, J.J., Sevilla, F., Jiménez, A., 2011. Response of mitochondrial thioredoxin PsTrxo1, antioxidant enzymes, and respiration to salinity in pea (Pisum sativum L.) leaves. J. Exp. Bot. 62, 3863-3874.

272 Lázaro, J.J., Jiménez, A., Camejo, D., Iglesias-Baena, I., Martí, M. del C., Lázaro-Payo, A., Barranco-Medina, S., Sevilla, F., 2013. Dissecting the integrative antioxidant and redox systems in plant mitochondria. Effect of stress and Snitrosylation. Front. Plant Sci. 4, 1-20

273 Vandelle, E., Delledonne, M., 2011. Peroxynitrite formation and function in plants. Plant Sci. 181, 534-539.

274 Mittal, S., Kumari, N., \& Sharma, V. (2012). Differential response of salt stress on Brassica juncea: photosynthetic performance, pigment, proline, D1 and antioxidant enzymes. Plant Physiol and Biochem. 54, 17-26.

275 Jiang, M., Ye, Z. hong, Zhang, H. juan, Miao, L. xiang, 2019. Broccoli Plants Over-expressing an ERF Transcription Factor Gene BoERF1 Facilitates Both Salt Stress and Sclerotinia Stem Rot Resistance. J. Plant Growth Regul. $38,1-13$.

276 Kurepa, J., Hérouart, D., Van Montagu, M., Inzé, D., 1997. Differential Expression of CuZn- and Fe-Superoxide Dismutase Genes of Tobacco during Development, Oxidative Stress, and Hormonal Treatments. Plant Cell Physiol. 38, 463-470.

277 Hernández, J.A., Corpas, F.J., Gómez, M., del Río, L.A., Sevilla, F., 1993. Salt-induced oxidative stress mediated by activated oxygen species in pea leaf mitochondria. Physiol. Plant. 89, 103-110.

278 Badawi, G.H., Yamauchi, Y., Shimada, E., Sasaki, R., Kawano, N., Tanaka, Kunisuke, Tanaka, Kiyoshi, 2004. Enhanced tolerance to salt stress and water deficit by overexpressing superoxide dismutase in tobacco (Nicotiana tabacum) chloroplasts. Plant Sci. 166, 919-928.

279 Menezes-Benavente, L., Teixeira, F.K., Kamei, C.L.A., Margis-Pinheiro, M., 2004. Salt stress induces altered expression of genes encoding antioxidant enzymes in seedlings of a Brazilian indica rice (Oryza sativa L.). Plant Sci. 166, 323-331.

280 Wang, M., Wang, Y., Zhang, Y., Li, C., Gong, S., Yan, S., Li, G., Hu, G., Ren, H., Yang, J., Yu, T., Yang, K., 2019. Comparative transcriptome analysis of salt-sensitive and salt-tolerant maize reveals potential mechanisms to enhance salt resistance. Genes and Genomics 1-21.

281 Bonifacio, A., Martins, M.O., Ribeiro, C.W., Fontenele, A. V., Carvalho, F.E.L., Margis-Pinheiro, M., Silveira, J.A.G., 2011. Role of peroxidases in the compensation of cytosolic ascorbate peroxidase knockdown in rice plants under abiotic stress. Plant, Cell Environ. 34, 1705-1722. 
282 Karthikeyan, B., Joe, M.M., Islam, M.R., Sa, T., 2012. ACC deaminase containing diazotrophic endophytic bacteria ameliorate salt stress in Catharanthus roseus through reduced ethylene levels and induction of antioxidative defense systems. Symbiosis 56, 77-86.

283 Pérez-Alfocea, F., Albacete, A., Ghanem, M. E., \& Dodd, I. C. (2010). Hormonal regulation of source - sink relations to maintain crop productivity under salinity: a case study of root-to-shoot signalling in tomato. Funct. Plant Biol. $37(7), 592$.

284 Parida, A.K., Das, A.B., 2005. Salt tolerance and salinity effects on plants: A review. Ecotoxicol. Environ. Saf. 60, 324 349 .

285 Yang, Z., Wang, M., Sun, Ling, Lu, S., Bi, D., Sun, Le, Song, Z., Zhang, S., Zhou, S., Liu, J., 2014. The MembraneAssociated Transcription Factor NAC089 Controls ER-Stress-Induced Programmed Cell Death in Plants PLoS genetics, 10(3), e1004243.

286 Hussain, S., Bai, Z., Huang, J., Cao, X., Zhu, L., Zhu, C., Khaskheli, M.A., Zhong, C., Jin, Q., Zhang, J., 2019.1 Methylcyclopropene Modulates Physiological, Biochemical, and Antioxidant Responses of Rice to Different Salt Stress Levels. Front. Plant Sci. 10, 1-18.

287 Khan, M.I.R., Asgher, M., Khan, N.A., 2014. Alleviation of salt-induced photosynthesis and growth inhibition by salicylic acid involves glycinebetaine and ethylene in mungbean (Vigna radiata L.). Plant Physiol. Biochem. 80, 67-74.

288 Sedigheh, H. G., Mortazavian, M., Norouzian, D., Atyabi, M., Akbarzadeh, A., Hasanpoor, K., \& Ghorbani, M. (2011). Oxidative stress and leaf senescence. BMC research notes, 4(1), 477.

289 Scharte, J., Schön, H., Weis, E., 2005. Photosynthesis and carbohydrate metabolism in tobacco leaves during an incompatible interaction with Phytophthora nicotianae. Plant, Cell Environ. 28, 1421-1435.

290 Che-Othman, M.H., Millar, A.H., Taylor, N.L., 2017. Connecting salt stress signalling pathways with salinity-induced changes in mitochondrial metabolic processes in $C_{3}$ plants. Plant Cell Environ. 40, 2875-2905.

291 El-Hendawy, S.E., Hu, Y., Schmidhalter, U., 2005. Growth, ion content, gas exchange, and water relations of wheat genotypes differing in salt tolerances. Aust. J. Agric. Res. 56, 123.

292 Wang, H., Huang, J., Bi, Y., 2010c. Induction of alternative respiratory pathway involves nitric oxide, hydrogen peroxide and ethylene under salt stress. Plant Signal. Behav. 5, 1636-1637.

293 Kingston-Smith, A.H., Thomas, H., Foyer, C.H., 1997. Chlorophyll a fluorescence, enzyme and antioxidant analyses provide evidence for the operation of alternative electron sinks during leaf senescence in a stay-green mutant of Festuca pratensis. Plant, Cell Environ. 20, 1323-1337.

294 Wang, P., Du, Y., Zhao, X., Miao, Y., \& Song, C. P. (2013). The MPK6-ERF6-ROS-responsive cis-acting Element7/GCC box complex modulates oxidative gene transcription and the oxidative response in Arabidopsis. Plant Physiol, 161(3), 1392-1408.

295 Killi, D., Haworth, M., 2017. Diffusive and Metabolic Constraints to Photosynthesis in Quinoa during Drought and Salt Stress. Plants 6, 49 .

296 Hodges, M., Dellero, Y., Keech, O., Betti, M., Raghavendra, A.S., Sage, R., Zhu, X.G., Allen, D.K., Weber, A.P.M., 2016. Perspectives for a better understanding of the metabolic integration of photorespiration within a complex plant primary metabolism network. J. Exp. Bot. 67, 3015-3026.

297 Foyer, C.H., Shigeoka, S., 2011. Understanding Oxidative Stress and Antioxidant Functions to Enhance Photosynthesis. Plant Physiol. 155, 93-100.

298 Kramer, D.M., Johnson, G., Kiirats, O., Edwards, G.E., 2004. New fluorescence parameters for the determination of Q A redox state and excitation energy fluxes. Photosynth. Res. 79, 209-218.

299 Murchie, E.H., Lawson, T., 2013. Chlorophyll fluorescence analysis: A guide to good practice and understanding some new applications. J. Exp. Bot. 64, 3983-3998.

300 Win, K.T., Fukuyo, T., Keiki, O., Ohwaki, Y., 2018. The ACC deaminase expressing endophyte Pseudomonas spp. Enhances $\mathrm{NaCl}$ stress tolerance by reducing stress-related ethylene production, resulting in improved growth, photosynthetic performance, and ionic balance in tomato plants. Plant Physiol. Biochem. 127, 599-607.

301 Chen, Z., Gallie, D.R., 2015. Ethylene Regulates Energy-Dependent Non-Photochemical Quenching in Arabidopsis through Repression of the Xanthophyll Cycle. PLoS One 10,1-41.

302 Huang, W., Yang, Y. J., \& Zhang, S. B. (2019). Photoinhibition of photosystem I under fluctuating light is linked to the insufficient $\Delta \mathrm{pH}$ upon a sudden transition from low to high light. Environ Exp Bot, 160, 112-119.

303 Zaghdoudi, M., Msilini, N., Govindachary, S., Lachaâl, M., Ouerghi, Z., Carpentier, R., 2011. Inhibition of photosystems i and II activities in salt stress-exposed Fenugreek (Trigonella foenum graecum). J. Photochem. Photobiol. B Biol. 105, $14-20$.

304 Khan, M. I. R., \& Khan, N. A. (2014). Ethylene reverses photosynthetic inhibition by nickel and zinc in mustard through changes in PS II activity, photosynthetic nitrogen use efficiency, and antioxidant metabolism. Protoplasma, 251(5), 10071019 .

305 Manaa, A., Mimouni, H., Wasti, S., Gharbi, E., Terras, A., Ahmed, H. Ben, 2014. Characterization of transgenic Arabidopsis and tomato plants antisensed for the ethylene receptor gene CcEIN4 under NaCl stress. J. Plant Interact. 9 , 539-549.

306 Brown, H. D., Jackson, R. T., \& Dupuy, H. J. (1964). Transport of sugar in Allium: effects of inhibitors and ethylene. Nature, 202(4933), 722.

307 Kępczyńska, E., \& Zielińska, S. (2013). The role of endogenous ethylene in carbohydrate metabolism of Medicago sativa L. somatic embryos in relation to their regenerative ability. J plant growth regul 32(1), 191-199.

308 Wuriyanghan, H., Zhang, B., Cao, W. H., Ma, B., Lei, G., Liu, Y. F., ... \& Cao, Y. R. (2009). The ethylene receptor ETR2 delays floral transition and affects starch accumulation in rice. The Plant Cell, 21(5), 1473-1494.

309 MacNeill, G.J., Mehrpouyan, S., Minow, M.A.A., Patterson, J.A., Tetlow, I.J., Emes, M.J., (2017). Starch as a source, starch as a sink: the bifunctional role of starch in carbon allocation. J. Exp. Bot. 68, 4433-4453. 
310 Krasensky, J., Jonak, C., (2012). Drought, salt, and temperature stress-induced metabolic rearrangements and regulatory networks $1-16$.

311 Keiper FJ, D.M. Chen, L.F. De Filippis (1998). Respiratory, Photosynthetic and Ultrastructural Changes Accompanying Salt Adaptation in Culture of Eucalyptus microcorys. J. Plant Physiol. 152, 564-573. 


\section{Publikációs lista}

\section{MTMT azonosító: 10037573}

A doktori eljárás alapját képező 2 db közlemény:

Borbély P, Bajkán Sz, Poór P, Tari I (2019) Exogenous 1-amiocyclopropane-1-carboxylic acid controls photosynthetic activity, accumulation of reactive oxygen or nitrogen species and macroelement content in tomato in long-term experiments. Journal of Plant Growth Regulation. 1-17. IF: 2,179 (2018)

Péter Poór, Judit Kovács, Péter Borbély, Zoltán Takács, Ágnes Szepesi, Irma Tari (2015) Salt stress-induced production of reactive oxygen- and nitrogen species and cell death in the ethylene receptor mutant Never ripe and wild type tomato roots Plant Physiol and Biochemistry 97:pp. 313-322. IF: 2,756 Nyilvános idézők összesen: 14 Független: 10 Függő: 4

\section{Referált folyóiratban megjelent közlemények:}

Poór, Péter; Borbély, Péter; Czékus, Zalán; Takács, Zoltán; Ördög, Attila; Popović, Boris; Tari, Irma (2019) Comparison of changes in water status and photosynthetic parameters in wild type and abscisic aciddeficient sitiens mutant of tomato (Solanum lycopersicum cv. Rheinlands Ruhm) exposed to sublethal and lethal salt stress Journal of Plant Physiology 232, pp. 130-140, 11 p. IF: 2,825

Poór P, Borbély P, Bódi N, Bagyánszky M, Tari I (2019) Effect of salicylic acid on photosynthetic activity and chloroplast morfology under light and prolonged darkness. Photosynthetica 57, 367-376. IF: 2,365

Zoltán Takács; Péter Poór; Péter Borbély; Zalán Czékus; Gabriella, Szalai; Irma Tari (2018) $\mathrm{H}_{2} \mathrm{O}_{2}$ homeostasis in wild-type and ethylene-insensitive Never ripe tomato in response to salicylic acid treatment in normal photoperiod and in prolonged darkness Plant Physiology and Biochemistry, 126, pp. 74-85. IF: 3,404

Poór P, Takács Z, Patyi G, Borbély P, Becsik O, Szekeres A, Tari I (2018) Dark-induced changes in the activity and the expression of tomato hexokinase genes depend ont he leaf age. South African Journal of Botany, 118, 98-104. IF: 1,504

Poór P, Ördög A, Czékus Z, Borbély P, Takács Z, Kovács J, Tari I (2018) Regulation of the key antioxidant enzymes by developmental processes and environmental stresses in the dark. Biologia Plantarum 62, pp 201-210. IF: 1,384

Poór P, Borbély P, Kovács J , Papp A, Szepesi Á, Takács Z, Tari I (2014) Opposite extremes in ethylene/nitric oxide ratio induce cell death in cell suspension culture and in root apices of tomato exposed to salt stress. Acta Biologica Hungarica 65:pp. 428-438. IF: 0,589

Összesített IF: 17,007

\section{Egyéb folyóiratcikkek:}

Orbán Cs., Csajbók Cs., É. Hegedüs N., Borbély P. (2015): Alteration of peroxidase activity, chlorophyll content and antioxidant-capacity of corn salad (Valerianella locusta) during storage. BioTechnology: An Indian Journal. 11(2):66-70.

\section{A doktori disszertációhoz kapcsolódó konferencia közlemények:}

Borbély Péter; Poór Péter; Hegedűs Dóra; Tari Irma (2019) Oxidatív stresszválasz kialakulása különböző etilén státuszú paradicsomban sóstressz alatt In: Poór Péter; Blázovics Anna (szerk.) Magyar SzabadgyökKutató Társaság X. Kongresszusa: Program és összefoglalók Szeged, Magyarország: Szegedi Tudományegyetem, (2019) p. 26

Borbély Péter, Poór Péter, Tari Irma (2018) Az etilén prekurzor, 1-aminociklopropán-1-karbonsav hatása paradicsomnövények fotoszintetikus aktivitására Hazai Fotoszintézis-kutatók Találkozója 2018. november 7-9. Mátrafüred (előadás)

Borbély P, Czékus Z, Hegedűs D, Kurtulus G, Péter P, Tari I. (2017) Az etilén szerepe a reaktív oxigén- és nitrogénformák akkumulációjának szabályozásában sóstressznek kitett paradicsomnövényekben. A Magyar Szabadgyök-Kutató Társaság 9. Kongresszusa, 2017. aug. 25-26., Gödöllö, Absztraktgyüjtemény 25. old. (előadás)

Péter Borbély, Zoltán Takács, Orsolya Csíkos, Péter Poór, Irma Tari (2017) Exogenous ACC treatment affects photosynthetic activity and related parameters of tomato plants by a concentration dependent manner. A Magyar Növénybiológiai Társaság 12. kongresszusa, Szeged, 2017. aug. 30-szept. 1. (poszter)

Péter Borbély, Péter Poór, Gábor Patyi, Irma Tari (2015) Effect of Ethylene Precursor ACC Pre-Treatment on Photosynthesis Under Salt Stress In: Jian-kang Zhu, Alisher Touraev (szerk.) Plant Abiotic Stress Tolerance III: Programme and Abstracts. Konferencia helye, ideje: Bécs, Ausztria, 2015.06.29.p. 63 (poszter) 


\section{Egyéb közlemények, poszterek, konferencia közlemények}

Marschall Marianna, Borbély Péter (2018) Újranedvesedés alatti fényvédelmi és regenerációs mechanizmusok háttérfolyamatainak, komponenseinek vizsgálata kiszáradástürő és kiszáradásérzékeny mohafajokban. Hazai Fotoszintézis-kutatók Találkozója 2018. november 7-9. Mátrafüred (előadás)

Marschall, M; Borbély, P ; Pné-Kónya, E; Sütö, Sz: Background processes and the components of photoprotection and regeneration under rehydration in desiccation-tolerant and desiccation-sensitive bryophytes Paper: 29, 1 p. In:Plant Biology Europe 2018 Conference : Photosynthesis Diversity Copenhagen, Dánia (2018) p. 1 (poszter)

Zalán, Czékus; Orsolya, Csíkos; Dóra, Hegedűs ; Péter, Borbély ; Attila, Ördög ; Péter, Poór: Investigation of dark modulated endoplasmatic reticulum (ER) stress in tomato plants p. 116 In: Tamás, László; Zelenyánszki, Helga (szerk.) Fiatal Biotechnológusok Országos Konferenciája "FIBOK 2018": Abstract Book, Szeged, Magyarország: JATEPress Kiadó, (2018) (előadás)

Poór Péter, Czékus Zalán, Borbély Péter, Takács Zoltán, Tari Irma: Növényi antioxidáns enzimek szalicilsav kezelést követő etilénfüggő szabályozása sötétben In: Mézes Miklós (szerk.) Magyar Szabadgyök-Kutató Társaság IX. Kongresszusa és az MTA ÉKB Mikroelem Munkabizottságának Tudományos Ülése. 2017.08.25 Gödöllő, Magyarország. (előadás)

Marschall M, Borbély P, Sütő Sz (2017) Újranedvesedés alatti fényvédelmi és regenerációs mechanizmusok háttérfolyamatainak, komponenseinek vizsgálata kiszáradástürő és kiszáradásérzékeny mohafajokban In: Györgyey János (szerk.) A Magyar Növénybiológiai Társaság XII. Kongresszusa. 72 p. 2017.08.30. Szeged, Magyarország. (előadás)

Kovács J, Poór P, Borbély P, Czékus Z, Tari I (2017) Sóstresszre adott válaszreakciók paradicsomban: nitrogénmonoxid, reaktív oxigénformák és proteolízis indukciója abszcizinsav hiányos paradicsom mutánsokban. A Magyar Szabadgyök-Kutató Társaság 9. Kongresszusa, 2017. aug. 25-26., Gödöllö, Absztraktgyüjtemény 24. old. (előadás)

Poór Péter; Zoltán, Takács ; Péter, Borbély ; Zalán, Czékus ; Irma, Tari (2017) Ethylene dependent changes in hydrogen-peroxide homeostasis after salicylic acid treatment in tomato p. 21 In: Andreas, Bachmair; Alisher, Touraev (szerk.) International Conference Plant Molecular Physiology:Programme and Abstracts (2017) 2017.02.23 (poszter)

Poór Péter, Judit Kovács, Ágnes Szepesi, Péter Borbély, Gábor Patyi, Irma Tari (2016) Salt stress-induced oxidative stress in ethylene signaling mutant, Never ripe tomato. HUSBR/1203/221/173 „PLANTTRAIN": Joint development of higher education and training programmes in plant biology in support of knowledge-based society. Closing Conference. 2016.05.23. Novi Sad. Serbia. (előadás)

Zoltán Takács, Zalán Czékus, Péter Poór, Péter Borbély, Irma Tari (2016) Effect of light on the salicylic-induced oxidative stress in tomato. HUSBR/1203/221/173 „PLANTTRAIN”: Joint development of higher education and training programmes in plant biology in support of knowledgebased society. Closing Conference. 2016.05.23. Novi Sad. Serbia (előadás)

Péter Poór, Zoltán Takács, Péter Borbély, Zalán Czékus, Gábor Patyi, Irma Tari (2016) Involvement of ethylene in hydrogenpepoxide metabolism in the leaves of salicylic acid treated tomato. Plant Biology Europe EPSO/FESPB 2016 Congress. 2016.06.26 Prága, Csehország (poszter)

Péter Poór, Zalán Czékus, Gábor Patyi, Péter Borbély, Judit Kovács, Zoltán Takács, Irma Tari: Investigation of Salt Stress-induced Changes in Water Status, Photosynthetic Parameters and Cysteine Protease Activity in Wild Type and Abscisic Acid-Deficient Sitiens Mutant of Tomato (Solanum Lycopersicum cv. Rheinland Ruhm). In: Andreas Bachmair, Klaus Palme, Alisher Touraev (szerk.) Programme and Abstracts: Plant Model Species: Fundamentals and Applications. 2016.02.04. Bécs. Ausztria. p.23. (poszter)

Tari Irma, Borbély Péter, Csiszár Jolán , Horváth Edit, Poór Péter, Szepesi Ágnes, Takács Zoltán (2016) Szalicilsav kémiai edzés hatása a paradicsom sóstressz toleranciájára In: Rajnai Zoltán, Fregán Beatrix , Marosné Kuna Zsuzsanna (szerk.) Tanulmánykötet a 7. BBK előadásaiból. 1-2. kötet . 1159 p. Konferencia helye, ideje: Budapest, Magyarország , 2016.05.19 -2016.05.20. Budapest: Óbudai Egyetem, Bánki Donát Gépész és Biztonságtechnikai Mérnöki Kar, 2016. pp. 407-416. (ISBN:978-615-5460-975) (előadás és kiadvány)

Poór, P., Kovács, J., Borbély, P., Takács, Z., Szepesi, Á., Tari, I. (2015) Sóstressz indukált változások a reaktív oxigén és nitrogénformák akkumulációjában etilénreceptor mutáns Never ripe és vad típusú paradicsomban. A Magyar Szabadgyök-Kutató Társaság VIII. Kongresszusa, Budapest, 2015. november 5-6. Absztraktfüzet, pp. 32.

Péter Poór, Attila Ördög, Barnabás Wodala , Péter Borbély , Ionel Samfira, Monica Butnariu, Dóra Hegedűs , Katalin Szabó , Attila Pécsváradi , Irma Tari (2015) Effect of Salinity Stress on Ion Accumulation and on the Photosynthetic Activity of a New Energy Plant, Phalaris arundinacea Cultivars. In: Alapi Tünde, 
Ilisz István (szerk.) Proceedings of the 21st International Symposium on Analytical and Environmental Problems . 445 p. Konferencia helye, ideje: Szeged, Magyarország , 2015.09.28 Szeged: Szegedi Tudományegyetem Szervetlen és Analitikai Kémiai Tanszék, 2015. p. 392-4.(ISBN:978-963-306-411-5) (poszter és kiadvány)

Péter Poór, Zoltán Takács, Péter Borbély, Ágnes Szepesi, Irma Tari (2015) Light and Darkness Modulate the Oxidative Burst And Enzymatic Antioxidant Systems In Salicylic Acid-Treated Tomato Leaf In: Laura De Gara, Massimo Delledonne (szerk.) 12th International Conference on Reactive Oxygen and Nitrogen Species in Plants: from model systems to field. Konferencia helye, ideje: Verona, Olaszország, 2015.06.24-2015.06.26.p. 111. (poszter)

Ágnes Szepesi, Péter Borbély, Ágnes Hurton, Zoltán Takács, Szabolcs Tóth, Izabella Kovács, Christian Lindermayr, Irma Tari (2015) Polyamine catabolism under salt stress: inhibiting diamine oxidase by aminoguanidine. In: Irma Tari, Dániel Benyó Joint development of higher education and training programmes in plant biology in support of knowledge-based society: Opening Conference, BOOK OF ABSTRACTS. 2015.04.20 Szeged, Magyarország, Szeged: p. 12. 1 p. (előadás)

Tari Irma, Borbély Péter , Csiszár Jolán, Gémes Katalin, Horváth Edit , Kovács Judit ,Poór Péter, Szepesi Ágnes, Takács Zoltán (2014) Sóstressz tolerancia fokozása szalicilsavval paradicsomban: az abszcizinsav szerepe. In: Fodor F (szerk.) Paál Árpádtól a molekuláris növénybiológiáig: Tudományos ülés Paál Árpád születésének 125. és intézetigazgatói kinevezésének 85. évfordulója alkalmából. Konferencia helye, ideje: Budapest, Magyarország, 2014.12.16 Budapest: ELTE Biológiai Intézet Növényélettani és Molekuláris Növénybiológiai Tanszék, 2014. pp. 55-59. (ISBN:978-963-284-561-6) (előadás és kiadvány)

Poór Péter, Kovács Judit, Borbély Péter Gábor, Takács Zoltán, Szepesi Ágnes, Tari Irma (2015) Exogén NO hatása a sóstressz indukált fiziológiai válaszreakciókra paradicsomban. Magyar Tudomány Ünnepe, Az MTA SZAB Biológiai Szakbizottság ünnepi tudományos ülése, Reprezentatív előadások a biológiai munkabizottságok kutatási területeiről. 2014. november 26: Szeged. Magyarország. (előadás)

Péter Borbély, Péter Poór, Judit Kovács, Zoltán Takács, Gábor Patyi, Ágnes Szepesi, Irma Tari (2015) Exogenous sodium nitroprusside alleviates salt-induced changes in photosynthesis of tomato leaves. In: Györgyey J (szerk.): 11th Congress of the Hungarian Society of Plant Biology: Book of Abstracts.: MTA Szegedi Biológiai Központ, Szeged, Magyarország, p. 61. 2014.09.27. (poszter) 


\section{Nyilatkozat}

Mint az alábbi közlemények felelős szerzője igazolom, hogy Borbély Péter Gábor Ph.D. jelölt jelentős mértékben hozzájárult az alábbi tudományos publikáció létrehozásához, és tézisében közölt eredményeit más Ph.D. értekezésben nem használjuk fel.

Borbély P, Bajkán Sz, Poór P, Tari I (2019) Exogenous 1-amiocyclopropane-1-carboxylic acid controls photosynthetic activity, accumulation of reactive oxygen or nitrogen species and macroelement content in tomato in long-term experiments. Journal of Plant Growth Regulation. 1-17.

Szeged, 2019. szeptember 23.

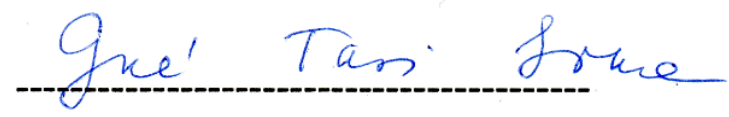

Dr. Görgényi Miklósné Dr. Habil. Tari Irma

egyetemi docens

\section{SZTE-TTIK Növénybiológiai Tanszék}

Péter Poór, Judit Kovács, Péter Borbély, Zoltán Takács, Ágnes Szepesi, Irma Tari (2015) Salt stress-induced production of reactive oxygen- and nitrogen species and cell death in the ethylene receptor mutant Never ripe and wild type tomato roots Plant Physiology and Biochemistry 97: pp.313-322.

Szeged, 2019. szeptember 23.

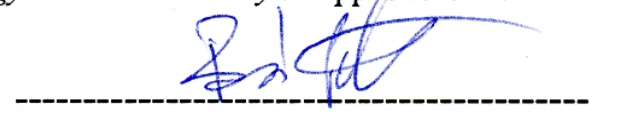

Dr. Poór Péter

egyetemi adjunktus

SZTE-TTIK Növénybiológiai Tanszék

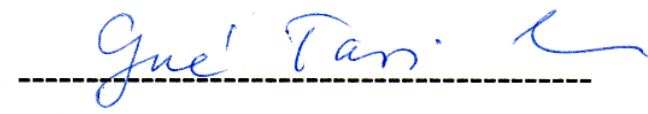

Dr. Görgényi Miklósné Dr. Habil. Tari Irma

egyetemi docens

SZTE-TTIK Növénybiológiai Tanszék 


\section{Köszönetnyilvánítás}

Szeretnék köszönetet mondani témavezetőmnek, Dr. Görgényi Miklósné Dr. Tari Irma Tanárnőnek, aki MSc. szakdolgozó korom óta végtelen türelemmel támogatott és tanított, továbbá, hogy korábbi tanszékvezetőként lehetőséget teremtett a $\mathrm{PhD}$. munkám elvégzéséhez! Segítsége és szakmai tudása felbecsülhetetlen a közös publikációk és a doktori disszertáció elkészítése során.

Hálás köszönettel tartozom Prof. Dr. Fehér Attilának, hogy tanszékvezetőként lehetővé tette a disszertációmhoz szükséges munka befejezését a Növénybiológiai Tanszéken! Támogatása és pozitív hozzáállása nélkülözhetetlen a disszertáció elkészüléséhez.

Köszönöm Dr. Ördögné Dr. Kolbert Zsuzsannának, hogy segítséget nyújtott a Ph.D. munkám folytatásához a Növénybiológiai Tanszéken.

Köszönöm Dr. Poór Péter mindennemü támogatását, mellyel elösegítette a laboratóriumi kísérletek és a disszertációm elkészülését.

Köszönöm Bécs Attiláné minden segítségét, mellyel megkönnyítette a laboratóriumi munkát, valamint külön köszönöm a fáradhatatlan segítségnyújtását a kísérletekhez használt növények nevelése során. Külön köszönettel tartozom Dóri Erikának, Kapásné Török Évának, Porkoláb Erzsébetnek és Tandari Máriának a mintafeldolgozások és egyéb, laboratóriumi munkák során nyújtott szakszerü segítségét!

Köszönöm Dr. Mainé Dr. Csiszár Jolánnak, Dr. Pécsváradi Attilának, Dr. Gallé Ágnesnek, Dr. Horváth Editnek, Dr. Szepesi Ágnesnek és Dr. Ördög Attilának, hogy mindig fordulhattam hozzájuk szakmai tanácsért!

Köszönöm Ph.D.-s társaimnak, Molnár Árpádnak, Czékus Zalánnak, Bakacsy Lászlónak, Dr. Németh Editnek, Dr. Bela Krisztinának, Riyazzudinnak, hogy segítségükkel minden technikai akadály legyőzhető volt és hogy személyiségükkel jókedvet varázsoltak a legkeményebb napokba is!

Köszönöm a szorgalmas szakdolgozóinknak, Hegedűs Dórának, Csíkos Orsolyának, Patyi Gábornak és Gamze Kurtulusnak minden segítségét!

Köszönöm továbbá a Növénybiológiai Tanszék valamennyi volt és jelenlegi munkatársának, hogy bármilyen formában segítették a munkám előrehaladását!

Köszönöm a NAIK-ÖVK munkatársainak, Dr. Jancsó Mihálynak és Dr. Penczi Andrásnak az ICP-MS mérések elvégzését, valamint az SZTE Mikrobiológiai Tanszék dolgozóinak a plate reader használatának lehetővé tételéért!

Legnagyobb köszönettel pedig szüleimnek, páromnak és a barátaimnak tartozom, akik minden helyzetben mellettem álltak! Támogatásuk nélkül képtelenség lett volna idáig eljutnom.

A dolgozat megvalósításához hozzájárultak az OTKA K101243 és a HUSRB/120/221/173 PLANTTRAIN IPA pályázatok. 


\section{Mellékletek}

1. melléklet A qRT-PCR analízishez használt oligonukleotid primer párok

\begin{tabular}{|c|c|c|c|c|}
\hline Gén neve & Rövidítés & Azonosító & Irány & Szekvencia (5'-3') \\
\hline \multirow{2}{*}{ Elongációs faktor $1 \alpha$} & \multirow{2}{*}{$S l E F 1 \alpha$} & \multirow{2}{*}{ Solyc06g005060 } & Forward & GGAACTTGAGAAGGAGCCTAAG \\
\hline & & & Reverz & CAACACCAACAGCAACAGTCT \\
\hline \multirow{2}{*}{$18 \mathrm{~S}$ riboszomális RNS } & \multirow{2}{*}{ Sl18SrRNS } & \multirow{2}{*}{ GQ280796 } & Forward & CGGAGAGGGAGCCTGAGAA \\
\hline & & & Reverz & CCCGTGTTAGGATTGGGTAATTT \\
\hline \multirow{2}{*}{$\begin{array}{l}\text { Mangán-szuperoxid- } \\
\text { dizmutáz }\end{array}$} & \multirow{2}{*}{ SlMnSOD } & \multirow{2}{*}{ Solyc06g049080 } & Forward & TTCTCTTGGCTGGGCTATTG \\
\hline & & & Reverz & AGCACCTTCTGCGTTCATCT \\
\hline \multirow{2}{*}{$\begin{array}{l}\text { Réz/cink-szuperoxid- } \\
\text { dizmutáz }\end{array}$} & \multirow{2}{*}{$S l C u / Z n S O D$} & \multirow{2}{*}{ Solyc01g067740 } & Forward & CCGACAAGCAGATTCCTCTC \\
\hline & & & Reverz & TCATGTCCTCССТTTCCAAG \\
\hline \multirow{2}{*}{ Vas-szuperoxid-dizmutáz } & \multirow{2}{*}{ SlFeSOD } & \multirow{2}{*}{ Solyc06g048410 } & Forward & ATCССТССТССТТАТССАATG \\
\hline & & & Reverz & GACATACGCCCTGTGATGC \\
\hline \multirow{2}{*}{ Kataláz 1} & \multirow{2}{*}{ SIKATI } & \multirow{2}{*}{ Solyc12g094620 } & Forward & GATGATGTTTGTCTCCCAACG \\
\hline & & & Reverz & AATGTGCTTTCCCCTCTTTGT \\
\hline \multirow{2}{*}{ Kataláz 2} & \multirow{2}{*}{ SIKAT2 } & \multirow{2}{*}{ Solyc02g082760 } & Forward & AACAACTTCCCCGTCTTCTTC \\
\hline & & & Reverz & TTAGGATTTGGCTTCAGAGCA \\
\hline \multirow{2}{*}{ Kataláz 3} & \multirow{2}{*}{ SIKAT3 } & \multirow{2}{*}{ Solyc04g082460 } & Forward & CCCTATTCCTCCTCGTGTCTT \\
\hline & & & Reverz & TGTAATGTTCTCCTGGCTGCT \\
\hline \multirow{2}{*}{ Aszkorbát-peroxidáz 1} & \multirow{2}{*}{ SlAPXI } & \multirow{2}{*}{ Solyc06g005160 } & Forward & CTGGTGTTGTTGCTGTTGAAG \\
\hline & & & Reverz & GCTCTGGCTTGTCCTCTCTG \\
\hline \multirow{2}{*}{ Aszkorbát-peroxidáz 2} & \multirow{2}{*}{ SIAPX2 } & \multirow{2}{*}{ Solyc06g005150 } & Forward & CTGGTGTTGTTGCTGTTGAAG \\
\hline & & & Reverz & GGTGGTTCTGGTTTGTCCTCT \\
\hline \multirow{2}{*}{ NADPH-oxidáz (RBOH1) } & \multirow{2}{*}{ SlRBOHI } & \multirow{2}{*}{ Solyc08g081690 } & Forward & TGGGGATGACTACTTGAGCA \\
\hline & & & Reverz & AAGCCTCGGAAAACACTCG \\
\hline
\end{tabular}

Az NCBI (http://www.ncbi.nlm.nih.gov/) és a Sol Genomics (http://solgenomics.net/) adatbázisok segítségével azonosított szekvenciákra a Primer 3 szoftverrel [223] terveztünk primereket, melyek génspecificitását az NCBI BLAST (http://blast.ncbi.nlm.nih.gov/Blast.cgi) használatával ellenöriztük. 


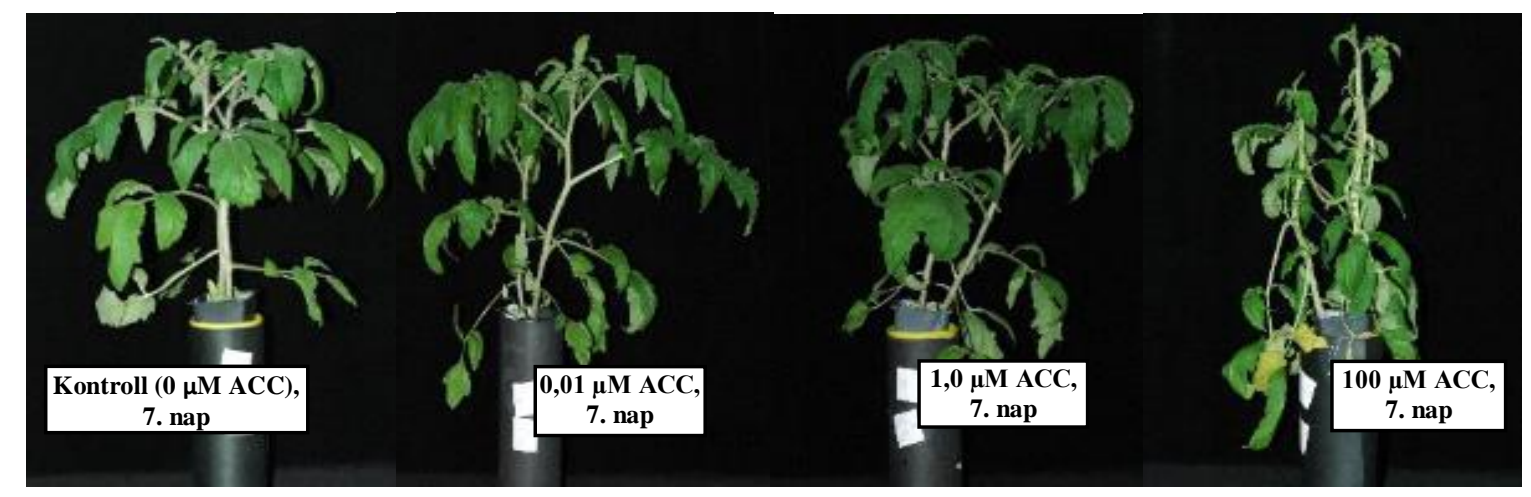

2. melléklet 1 hetes, 0,01, 1,0 és $100 \mu \mathrm{M}$ ACC kezelésnek kitett paradicsom hajtások morfológiai változásai 
3. melléklet SOD, KAT és APX izoenzimek, illetve az SIRBOHI gének relatív expressziója a gyökérben.

\begin{tabular}{|c|c|c|c|c|c|c|c|c|c|c|c|c|c|c|c|c|c|c|c|c|c|}
\hline Gyökér & & IMnSO & & & SIKATI & & & SIKAT2 & & & SIKAT3 & & & SLPX & & & SLAPX2 & & & $\mathrm{YRBOH}$ & \\
\hline Kezelés $\quad$ Ór: & 1 & 6 & 24 & 1 & 6 & 24 & 1 & 6 & 24 & 1 & 6 & 24 & 1 & 6 & 24 & 1 & 6 & 24 & 1 & 6 & 24 \\
\hline VT & $\begin{array}{c}0,00 \\
\pm 0,1^{\text {bc }}\end{array}$ & $\begin{array}{c}0,00 \\
\pm 0,0^{\mathrm{f}}\end{array}$ & $\begin{array}{c}0,00 \\
\pm 0,1^{\circ}\end{array}$ & $\begin{array}{c}0,00 \\
\pm 0,2^{\mathrm{f}}\end{array}$ & $\begin{array}{c}0,00 \\
\pm 0,0^{\mathrm{b}}\end{array}$ & $\begin{array}{c}0,00 \\
\pm 0,0^{d}\end{array}$ & $\begin{array}{c}0,00 \\
\pm 0,3^{\text {ac }}\end{array}$ & $\begin{array}{c}0,00 \\
\pm 0,7^{\circ}\end{array}$ & $\begin{array}{c}0,00 \\
\pm 0,1^{\mathrm{a}}\end{array}$ & $\begin{array}{c}0,00 \\
\pm 0,3^{\circ}\end{array}$ & $\begin{array}{c}0,00 \\
\pm 0,3^{\mathrm{d}}\end{array}$ & $\begin{array}{c}0,00 \\
\pm 0,1^{\mathrm{e}}\end{array}$ & $\begin{array}{c}0,00 \\
\pm 0,1^{\mathrm{ab}}\end{array}$ & $\begin{array}{c}0,00 \\
\pm 0,8^{\mathrm{d}}\end{array}$ & $\begin{array}{c}0,00 \\
\pm 0,2^{\circ}\end{array}$ & $\begin{array}{c}0,00 \\
\pm 0,1^{\mathrm{a}}\end{array}$ & $\begin{array}{c}0,00 \\
\pm 0,0^{\mathrm{g}}\end{array}$ & \begin{tabular}{|c|}
0,00 \\
$\pm 0,0^{\mathrm{ab}}$
\end{tabular} & $\begin{array}{c}0,00 \\
\pm 0,5^{\circ}\end{array}$ & $\begin{array}{c}0,00 \\
\pm 0,4^{\circ}\end{array}$ & $\begin{array}{c}0,00 \\
\pm 0,1^{\mathrm{f}}\end{array}$ \\
\hline$\sum_{\mathrm{ACC}}^{\mathrm{VT}+10 \mu \mathrm{M}}$ & $\begin{array}{c}-0,76 \pm \\
0,0^{\circ}\end{array}$ & $\begin{array}{r}0,83 \\
\pm 0,0^{\text {cd }}\end{array}$ & $\begin{array}{c}0,69 \\
\pm 0,0^{\mathrm{b}}\end{array}$ & $\begin{array}{c}0,6 \\
\pm 0,0^{\text {de }}\end{array}$ & $\begin{array}{l}-2,27 \\
\pm 0,2^{\mathrm{d}}\end{array}$ & $\begin{array}{c}1,96 \\
\pm 0,1^{\mathrm{a}}\end{array}$ & $\begin{array}{l}-3,51 \\
\pm 0,3^{\mathrm{r}}\end{array}$ & $\begin{array}{c}2,05 \\
\pm 0,1^{\text {alt }}\end{array}$ & $\begin{array}{l}-1,95 \\
\pm 0,1^{\circ}\end{array}$ & $\begin{array}{l}-1,78 \\
\pm 0,0^{\circ}\end{array}$ & $\begin{array}{c}1,22 \\
\pm 0,1^{\mathrm{b}}\end{array}$ & $\begin{array}{l}-1,59 \\
\pm 0,0^{\mathrm{r}}\end{array}$ & $\begin{array}{r}-0,30 \\
\pm 0,1^{\mathrm{bc}}\end{array}$ & $\begin{array}{c}2,71 \\
\pm 0,5^{\mathrm{b}}\end{array}$ & $\begin{array}{c}1,18 \\
\pm 0,5^{\mathrm{a}}\end{array}$ & $\begin{array}{l}-0,87 \\
\pm 0,1^{\mathrm{c}}\end{array}$ & $\begin{array}{c}3,30 \\
\pm 0,0^{\text {cid }}\end{array}$ & \begin{tabular}{|c|}
$-0,73$ \\
$\pm 0,5^{\mathrm{cd}}$
\end{tabular} & $\begin{array}{l}-2,37 \\
\pm 0,4^{d}\end{array}$ & $\begin{array}{c}1,04 \\
\pm 0,2^{\mathrm{b}}\end{array}$ & $\begin{array}{c}1,97 \\
\pm 0,1^{1 b c}\end{array}$ \\
\hline $\mathrm{Nr}$ & $\begin{array}{c}0,70 \\
\pm 0,0^{\mathrm{a}}\end{array}$ & $\begin{array}{c}1,01 \\
\pm 0,0^{\text {cd }}\end{array}$ & $\begin{array}{l}-1,69 \\
\pm 0,1^{\circ}\end{array}$ & $\begin{array}{c}3,80 \\
\pm 0,1^{\mathrm{a}}\end{array}$ & \begin{tabular}{|l|}
$-0,69$ \\
$\pm 0,1^{\mathrm{c}}$
\end{tabular} & \begin{tabular}{|l|}
$-1,06$ \\
$\pm 0,0^{\mathrm{r}}$
\end{tabular} & $\begin{array}{c}0,34 \\
\pm 0,1^{\mathrm{a}}\end{array}$ & $\begin{array}{c}1,48 \\
\pm 0,1^{\mathrm{b}}\end{array}$ & $\begin{array}{l}-2,70 \\
\pm 0,1^{\mathrm{d}}\end{array}$ & $\begin{array}{c}0,69 \\
\pm 0,1^{\mathrm{b}}\end{array}$ & $\begin{array}{c}0,43 \\
\pm 0,1^{\text {cd }}\end{array} \mid$ & $\begin{array}{l}-1,89 \\
\pm 0,1^{\mathrm{r}}\end{array}$ & $\begin{array}{l}-1,17 \\
\pm 0,2^{\mathrm{d}}\end{array}$ & $\begin{array}{c}1,82 \\
\pm 0,1^{\mathrm{bc}}\end{array}$ & $\begin{array}{l}-1,02 \\
\pm 0,1^{\mathrm{d}}\end{array}$ & $\begin{array}{l}-1,28 \\
\pm 0,1^{\mathrm{d}}\end{array}$ & $\begin{array}{c}3,53 \\
\pm 0,1^{\mathrm{cd}}\end{array}$ & \begin{tabular}{|l|}
$-1,15$ \\
$\pm 0,0^{\mathrm{d}}$
\end{tabular} & $\begin{array}{l}1,72 \\
\pm 0,6^{6}\end{array}$ & $\begin{array}{c}1,72 \\
\pm 0,1^{\mathrm{A}}\end{array}$ & $\begin{array}{c}2,45 \\
\pm 0,1^{b}\end{array}$ \\
\hline VT & $\begin{array}{c}-0,16 \pm \\
0,0^{\circ}\end{array}$ & $\begin{array}{c}1,19 \\
\pm 0,1^{\circ}\end{array}$ & $\begin{array}{c}0,13 \\
\pm 0,2^{\circ}\end{array}$ & $\begin{array}{c}3,48 \\
\pm 0,2^{\mathrm{a}}\end{array}$ & $\begin{array}{l}-0,48 \\
\pm 0,0^{\circ}\end{array}$ & $\begin{array}{c}0,93 \\
\pm 0,1^{\circ}\end{array}$ & $\begin{array}{c}-0,98 \\
\pm 0,1^{d}\end{array}$ & $\begin{array}{c}1,30 \\
\pm 0,1^{\mathrm{b}}\end{array}$ & $\begin{array}{l}-1,30 \\
\pm 0,0^{\mathrm{b}}\end{array}$ & $\begin{array}{l}-1,29 \\
\pm 0,2^{\mathrm{e}}\end{array}$ & $\begin{array}{c}1,13 \\
\pm 0,1^{\mathrm{b}}\end{array}$ & $\begin{array}{c}1,47 \\
\pm 0,1^{b c}\end{array}$ & $\begin{array}{l}-0,45 \\
\pm 0,2^{\circ}\end{array}$ & $\begin{array}{c}0,73 \\
\pm 0,5^{\text {ed }}\end{array}$ & $\begin{array}{c}0,17 \\
\pm 0,2^{\mathrm{bc}}\end{array}$ & $\begin{array}{c}-0,51 \\
\pm 0,1^{b}\end{array}$ & $\begin{array}{c}1,87 \\
\pm 0,4^{\mathrm{f}}\end{array}$ & $\begin{array}{c}-0,35 \\
\pm 0,0^{b c}\end{array}$ & $\begin{array}{c}1,87 \\
\pm 0,0^{\mathrm{b}}\end{array}$ & $\begin{array}{l}-0,36 \\
\pm 0,2^{\circ}\end{array}$ & $\begin{array}{c}0,39 \\
\pm 0,2^{\mathrm{ef}}\end{array}$ \\
\hline $\begin{array}{l}\mathrm{VT}+10 \mu \mathrm{M} \\
\mathrm{ACC}\end{array}$ & $\begin{array}{c}0,26 \\
\pm 0,0^{\mathrm{b}}\end{array}$ & $\begin{array}{c}0,63 \\
\pm 0,0 \mathrm{~d}^{2}\end{array}$ & $\begin{array}{l}-0,88 \\
\pm 0,2^{\mathrm{d}}\end{array}$ & \begin{tabular}{|c}
3,06 \\
$\pm 0,2^{\mathrm{b}}$
\end{tabular} & \begin{tabular}{|c|}
0,09 \\
$\pm 0,1^{b}$
\end{tabular} & \begin{tabular}{|c|}
$-0,42$ \\
$\pm 0,3^{\mathrm{dx}}$
\end{tabular} & $\begin{array}{l}-0,20 \\
\pm 0,1^{\mathrm{bc}}\end{array}$ & $\begin{array}{c}1,68 \\
\pm 0,2^{\text {wh }}\end{array}$ & $\begin{array}{l}-2,23 \\
\pm 0,2^{\circ}\end{array}$ & $\begin{array}{c}1,49 \\
\pm 0,0^{\mathrm{a}}\end{array}$ & $\begin{array}{c}0,41 \\
\pm 0,0^{\text {cal }}\end{array}$ & $\begin{array}{l}-1,36 \\
\pm 0,1^{r}\end{array}$ & $\begin{array}{l}-1,14 \\
\pm 0,1^{\mathrm{d}}\end{array}$ & $\begin{array}{c}0,84 \\
\pm 0,4^{\text {det }}\end{array}$ & $\begin{array}{c}-0,86 \\
\pm 0,1^{\mathrm{d}}\end{array}$ & $\begin{array}{l}-1,40 \\
\pm 0,0^{\mathrm{d}}\end{array}$ & $\begin{array}{c}2,92 \\
\pm 0,1^{\mathrm{e}}\end{array}$ & \begin{tabular}{|l|}
$-1,24$ \\
$\pm 0,0^{\mathrm{d}}$
\end{tabular} & $\begin{array}{l}-0,56 \\
\pm 0,4^{c}\end{array}$ & $\begin{array}{c}0,86 \\
\pm 0,3^{\mathrm{b}}\end{array}$ & $\begin{array}{c}0,95 \\
\pm 0,0^{\mathrm{de}}\end{array}$ \\
\hline Nr & $\begin{array}{c}-0,12 \pm \\
0,2^{\mathrm{c}}\end{array}$ & $\begin{array}{c}2,03 \\
\pm 0,0^{\mathrm{b}}\end{array}$ & $\begin{array}{c}1,49 \\
\pm 0,0^{\mathrm{a}}\end{array}$ & $\begin{array}{c}1,25 \\
\pm 0,0^{\mathrm{c}}\end{array}$ & $\begin{array}{l}-0,42 \\
\pm 0,2^{\mathrm{c}}\end{array}$ & $\begin{array}{r}1,39 \\
\pm 0,1^{1}\end{array}$ & $\begin{array}{c}0,20 \\
\pm 0,1^{\text {th }}\end{array}$ & $\begin{array}{c}1,49 \\
\pm 0,0^{\mathrm{b}}\end{array}$ & \begin{tabular}{|c|}
$-0,45$ \\
$\pm 0,1^{\mathrm{A}}$
\end{tabular} & $\begin{array}{c}-0,42 \\
\pm 0,1^{\text {wat }}\end{array}$ & $\begin{array}{c}1,02 \\
\pm 0,1^{1 \mathrm{c}}\end{array}$ & $\begin{array}{c}1,82 \\
\pm 0,2^{\mathrm{b}}\end{array}$ & $\begin{array}{l}-0,85 \\
\pm 0,1^{\mathrm{d}}\end{array}$ & $\begin{array}{c}2,41 \\
\pm 0,2^{b}\end{array}$ & $\begin{array}{c}0,65 \\
\pm 0,0^{\text {ath }}\end{array}$ & $\begin{array}{l}-0,21 \\
\pm 0,2^{\text {at }}\end{array}$ & $\begin{array}{c}4,49 \\
\pm 0,1^{\mathrm{b}}\end{array}$ & \begin{tabular}{|c|}
0,54 \\
$\pm 0,0^{\mathrm{a}}$
\end{tabular} & $\begin{array}{c}3,54 \\
\pm 0,0^{\mathrm{n}}\end{array}$ & $\begin{array}{c}2,38 \\
\pm 0,1^{n}\end{array}$ & $\begin{array}{c}3,67 \\
\pm 0,2^{\mathrm{a}}\end{array}$ \\
\hline VT & $\begin{array}{c}-1,12 \pm \\
0,0^{\mathrm{f}}\end{array}$ & $\begin{array}{c}0,34 \\
\pm 0,2^{\text {ef }}\end{array}$ & $\begin{array}{c}0,27 \\
\pm 0,2 \mathrm{~b}^{\mathrm{c}}\end{array}$ & $\begin{array}{l}-0,80 \\
\pm 0,0^{\mathrm{R}}\end{array}$ & \begin{tabular}{|l|}
$-4,26$ \\
$\pm 0,0^{\mathrm{f}}$
\end{tabular} & \begin{tabular}{|l|}
$-0,17$ \\
$\pm 0,2^{\mathrm{d}}$
\end{tabular} & $\begin{array}{l}-1,53 \\
\pm 0,0^{\circ}\end{array}$ & $\begin{array}{c}1,29 \\
\pm 0,1^{\mathrm{b}}\end{array}$ & \begin{tabular}{|l|}
$-4,52$ \\
$\pm 0,1^{\mathrm{f}}$
\end{tabular} & $\begin{array}{l}-2,87 \\
\pm 0,0^{f}\end{array}$ & $\begin{array}{c}0,02 \\
\pm 0,1^{\mathrm{d}}\end{array}$ & $\begin{array}{c}1,02 \\
\pm 0,1^{\circ}\end{array}$ & $\begin{array}{c}0,26 \\
\pm 0,1^{\text {a }}\end{array}$ & $\begin{array}{c}1,56 \\
\pm 0,1^{\mathrm{bc}}\end{array}$ & $\begin{array}{l}-1,12 \\
\pm 0,2^{\mathrm{de}}\end{array}$ & $\begin{array}{l}-1,40 \\
\pm 0,0^{\mathrm{d}}\end{array}$ & $\begin{array}{c}2,99 \\
\pm 0,0^{\mathrm{de}}\end{array}$ & \begin{tabular}{|c|}
0,26 \\
$\pm 0,1^{\mathrm{ab}}$
\end{tabular} & $\begin{array}{l}-1,24 \\
\pm 0,2^{\text {cd }}\end{array}$ & $\begin{array}{c}-2,13 \\
\pm 0,2^{\mathrm{d}}\end{array}$ & $\begin{array}{l}-1,53 \\
\pm 0,6^{2}\end{array}$ \\
\hline$\sum_{\mathrm{E}}^{\mathrm{Z}} \mathrm{VT}+10 \mu \mathrm{M}$ & $\begin{array}{c}0,11 \\
\pm 0,3^{\mathrm{bc}}\end{array}$ & $\begin{array}{c}1,02 \\
\pm 0,0^{\text {cd }}\end{array}$ & $\begin{array}{c}0,28 \\
\pm 0,2 \mathrm{~b}^{\mathrm{c}}\end{array}$ & $\begin{array}{c}0,75 \\
\pm 0,0^{\mathrm{d}}\end{array}$ & $\begin{array}{l}-3,86 \\
\pm 0,0^{a}\end{array}$ & $\begin{array}{c}1,22 \\
\pm 0,2^{\mathrm{bc}}\end{array}$ & $\begin{array}{l}-0,48 \\
\pm 0,2^{\circ}\end{array}$ & $\begin{array}{c}0,33 \\
\pm 0,1^{\mathrm{c}}\end{array}$ & \begin{tabular}{|l|}
$-3,50$ \\
$\pm 0,3^{\mathrm{e}}$
\end{tabular} & $\begin{array}{l}-0,76 \\
\pm 0,0^{\mathrm{d}}\end{array}$ & $\begin{array}{c}1,34 \\
\pm 0,5^{\mathrm{b}}\end{array}$ & $\begin{array}{c}2,40 \\
\pm 0,0^{\mathrm{a}}\end{array}$ & $\begin{array}{l}-0,45 \\
\pm 0,1^{\mathrm{c}}\end{array}$ & $\begin{array}{c}1,92 \\
\pm 0,2^{\mathrm{bc}}\end{array}$ & $\begin{array}{c}0,55 \\
\pm 0,0^{\mathrm{bc}}\end{array}$ & $\begin{array}{c}-0,43 \\
\pm 0,1 \mathrm{~b}\end{array}$ & $\begin{array}{c}3,87 \\
\pm 0,3^{\mathrm{c}}\end{array}$ & \begin{tabular}{|c|}
0,00 \\
$\pm 0,1^{\mathrm{ab}}$
\end{tabular} & $\begin{array}{l}-2,03 \\
\pm 0,7^{\mathrm{d}}\end{array}$ & $\begin{array}{c}-0,32 \\
\pm 0,4^{\mathrm{c}}\end{array}$ & $\begin{array}{l}-2,07 \\
\pm 0,4^{\mathrm{g}}\end{array}$ \\
\hline $\mathrm{Nr}$ & $\begin{array}{c}-0,10 \pm \\
0,0^{\circ}\end{array}$ & $\begin{array}{c}3,96 \\
\pm 0,2^{\mathrm{a}}\end{array}$ & $\begin{array}{c}-1,18 \pm \\
0,1^{\mathrm{d}}\end{array}$ & $\begin{array}{c}0,26 \\
\pm 0,1^{\text {lef }}\end{array}$ & \begin{tabular}{|c|}
0,74 \\
$\pm 0,2^{a}$
\end{tabular} & \begin{tabular}{|c|}
$-0,63$ \\
$\pm 0,1^{e}$
\end{tabular} & $\begin{array}{l}-1,66 \\
\pm 0,1^{\mathrm{e}}\end{array}$ & $\begin{array}{c}2,41 \\
\pm 0, \mathrm{l}^{\mathrm{a}}\end{array}$ & \begin{tabular}{|l|}
$-3,81$ \\
$\pm 0,0^{\mathrm{e}}$
\end{tabular} & $\begin{array}{l}-1,37 \\
\pm 0,4^{\mathrm{e}}\end{array}$ & $\begin{array}{c}2,23 \\
\pm 0,1^{\mathrm{a}}\end{array}$ & $\begin{array}{c}0,00 \\
\pm 0,4^{\mathrm{de}}\end{array}$ & $\begin{array}{l}-2,98 \\
\pm 0,0^{e}\end{array}$ & $\begin{array}{c}4,28 \\
\pm 0,0^{\mathrm{a}}\end{array}$ & $\begin{array}{l}-1,65 \\
\pm 0,0^{\mathrm{e}}\end{array}$ & $\begin{array}{l}-2,23 \\
\pm 0,1^{\mathrm{e}}\end{array}$ & $\begin{array}{c}5,74 \\
\pm 0,1^{\mathrm{a}}\end{array}$ & \begin{tabular}{|l|}
$-1,87$ \\
$\pm 0,0^{e}$
\end{tabular} & $\begin{array}{c}1,45 \\
\pm 0,1^{\mathrm{b}}\end{array}$ & $\begin{array}{c}1,83 \\
\pm 0,2^{\mathrm{a}}\end{array}$ & $\begin{array}{c}1,37 \\
\pm 0,4^{\mathrm{cd}}\end{array}$ \\
\hline
\end{tabular}

Relatív expressziós szintek $\log _{2}$ értékének ábrázolása, VT és $N r$ mutáns $(0 \mu \mathrm{M} \mathrm{ACC})$, valamint $10 \mu \mathrm{M}$ ACC-vel kezelt VT paradicsomnövények gyökereiben, a $100 \mathrm{mM}$ ill. $250 \mathrm{mM}$-os $\mathrm{NaCl}$ hozzáadását követő 1, 6, ill. 24 óra elteltével. Átlag $\pm \mathrm{SE}$, n=3). A kísérlet kezdő időpontja a VT növények ACC kezelése 1. órájának leteltétől számítva. A különböző betűvel jelölt cellák szignifikáns különbségeket mutatnak $\mathrm{P} \leq 0,05$ szinten az adott időpontokon belül (Duncan teszt). 


\begin{tabular}{|c|c|c|c|c|c|c|c|c|c|c|}
\hline & & $\begin{array}{l}0.8 \\
m=0 \\
y_{0}^{0}\end{array}$ & $\begin{array}{l}8 \\
8 \\
0^{\circ}\end{array}$ & $\begin{array}{l}0.0 \\
0.0 \\
0.0 \\
10\end{array}$ & 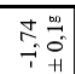 & 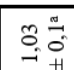 & \begin{tabular}{|ll}
$n_{0}^{0}$ \\
0.0 \\
0
\end{tabular} & 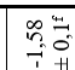 & $\begin{array}{ll}7 \\
7\end{array}$ & \\
\hline & $\begin{array}{l}0 \\
0 \\
0 \\
+1\end{array}$ & 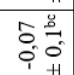 & 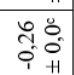 & 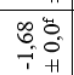 & 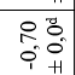 & 官: & $\begin{array}{l}n \\
30 \\
0.0 \\
0 \\
0\end{array}$ & 웅ㅇ․ & 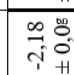 & \\
\hline & $\left.\begin{array}{l}0 \\
0 \\
0 \\
+ \\
+1\end{array}\right]$ & $\begin{array}{l}03 \\
00 \\
0 \\
100\end{array}$ & $\begin{array}{l}= \\
=8 \\
0 \\
10\end{array}$ & $\begin{array}{l}\infty \\
a_{0}^{0} \\
0.0 \\
0 \\
0\end{array}$ & 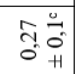 & $\mid \begin{array}{l}0 \\
0 \\
-i \\
-1\end{array}$ & $\begin{array}{l}0.0 \\
0 \\
0 \\
0\end{array}$ & तิ & $\begin{array}{l}\infty \\
\infty \\
0.01 \\
0.01\end{array}$ & \\
\hline $\mathbb{\pi}$ & 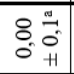 & $\begin{array}{l}20 \\
30 \\
70 \\
1\end{array}$ & 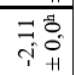 & 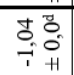 & 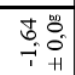 & 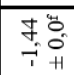 & $\mid \begin{array}{ll}\infty & 0 \\
0.0 \\
0\end{array}$ & 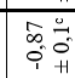 & $F_{0}^{\circ}$ & \\
\hline & 80 & $8:=$ & $\begin{array}{ll}\sigma \\
0.0 \\
0\end{array}$ & $\begin{array}{ll}0.0 \\
0 \\
0\end{array}$ & శ్రి: & $\therefore 0$ & 金: & to & 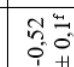 & \\
\hline & 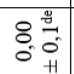 & 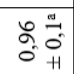 & 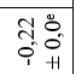 & 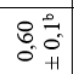 & 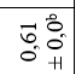 & $\begin{array}{l}n \\
n \\
n \\
0 \\
0\end{array}$ & $\begin{array}{l}6 \\
0.7 \\
0 \\
0\end{array}$ & to & $\begin{array}{c}20 \\
0.0 \\
1+1\end{array}$ & \\
\hline 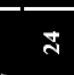 & $\begin{array}{ccc}0 & 0 \\
0 & 0 \\
0 \\
+1\end{array}$ & 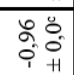 & 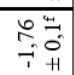 & 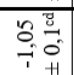 & $\begin{array}{c}n \\
0 \\
-10 \\
-1 \\
10\end{array}$ & 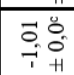 & $\mid$\begin{tabular}{|l|l}
8 \\
0 \\
0.0 \\
$1+0$
\end{tabular} & $\stackrel{\substack{\infty \\
\hdashline \\
\hdashline}}{\circ}$ & $\begin{array}{l}90 \\
90 \\
70\end{array}$ & \\
\hline & $\begin{array}{l}0.0 \\
8.0 \\
0.0 \\
0\end{array}$ & 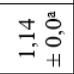 & 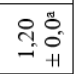 & 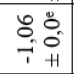 & 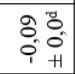 & $\begin{array}{l}\hat{y}_{0}^{0} \\
0.0 \\
0\end{array}$ & $\begin{array}{l}0 \\
0: 0 \\
0.0 \\
0\end{array}$ & $\begin{array}{l}0.0 \\
0 \\
0.0\end{array}$ & 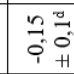 & \\
\hline & 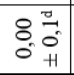 & $\begin{array}{l}m \\
\hat{m}= \\
0^{\circ}\end{array}$ & $\begin{array}{l}n \\
n \\
n=0 \\
0.0 \\
0\end{array}$ & 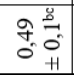 & $\begin{array}{l}0 \\
0 \\
0 \\
0 \\
0 \\
0 \\
+1\end{array}$ & $\begin{array}{l}\infty \\
\stackrel{0}{0} \\
-0 \\
-1\end{array}$ & $\begin{array}{l}3: 0 \\
0: 0 \\
0\end{array}$ & $\begin{array}{l}\overrightarrow{0} .7 \\
0.0 \\
0\end{array}$ & $\begin{array}{l}6: 0 \\
0.0 \\
0\end{array}$ & \\
\hline & 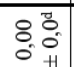 & $\begin{array}{l}6.0 \\
0.0 \\
0.0\end{array}$ & 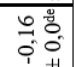 & $\begin{array}{ll} & 0 \\
0 \\
0 \\
0\end{array}$ & 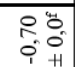 & $\begin{array}{ll}m \\
m \\
0\end{array}$ & $\begin{array}{ll}n \\
n \\
0\end{array}$ & m: & n. & \\
\hline & 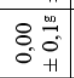 & 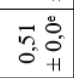 & 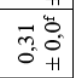 & $\begin{array}{l}t^{2}= \\
t^{2} \\
0^{\circ} \\
+\end{array}$ & 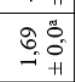 & $\frac{m}{m}=0$ & 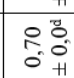 & fo & $\stackrel{\infty}{\circ}=$ & \\
\hline & $\begin{array}{l}8 \\
8 \\
0.0 \\
0\end{array}$ & $\begin{array}{l}8 \% \\
0=0 \\
0^{\circ}+1\end{array}$ & 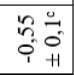 & $\begin{array}{l}8 \% \\
\therefore=0 \\
0\end{array}$ & 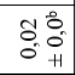 & 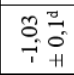 & $\begin{array}{ll}\infty & 0 \\
0 & 0 \\
0 & 0 \\
0\end{array}$ & $\begin{array}{l}0.1 \\
0 \\
0 \\
0\end{array}$ & $\begin{array}{l}0 \\
0 \\
+1 \\
+1\end{array}$ & \\
\hline $\mathbb{A}$ & & 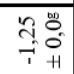 & $\begin{array}{l}\overrightarrow{0}:= \\
0_{0}^{\circ}\end{array}$ & 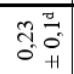 & 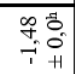 & $\begin{array}{ll}2 & 0 \\
0 & 0 \\
-1 & 0 \\
+1\end{array}$ & $\mid \begin{array}{l}\infty \\
\infty \\
0.0 \\
i^{2}+\end{array}$ & 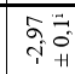 & $\begin{array}{c}80 \\
0 \\
-1\end{array}$ & \\
\hline & $\begin{array}{l}\delta_{0}^{0} \\
0_{0}^{\circ} \\
0^{\prime}\end{array}$ & 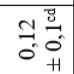 & 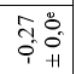 & $\begin{array}{l}\text { ro: } \\
\text { ת. } \\
0 \\
0 \\
+\end{array}$ & $\begin{array}{l}n=0 \\
n \\
0 \\
0 \\
0\end{array}$ & $\begin{array}{l}30 \\
0 \\
0 \\
0\end{array}$ & 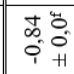 & $\begin{array}{l}m: \\
m=0 \\
0.0\end{array}$ & $\begin{array}{l}\vec{a} \\
\overrightarrow{0} \\
\vec{T}\end{array}$ & \\
\hline & $\begin{array}{l}8 \\
8 \\
0.0 \\
0 \\
0\end{array}$ & 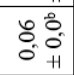 & 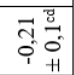 & 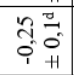 & $\begin{array}{l}0 \\
0.0 \\
0.0 \\
0 \\
0+1\end{array}$ & $\begin{array}{l}2 \\
\text { 20. } \\
0 \\
0 \\
+\end{array}$ & 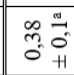 & $\begin{array}{l}2 \\
0 \\
0.0\end{array}$ & 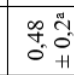 & \\
\hline & $\begin{array}{l}8 \\
8 \\
0.0 \\
0\end{array}$ & $\begin{array}{l}n \\
70 \\
0.0 \\
0.0\end{array}$ & 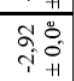 & 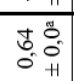 & 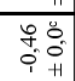 & 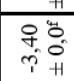 & \begin{tabular}{|l|}
$\vec{n}$ \\
0 \\
0 \\
0
\end{tabular} & 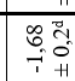 & $\begin{array}{l}n \\
0 \\
0 \\
+1\end{array}$ & \\
\hline & & 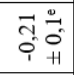 & $\begin{array}{l}m: \\
n=0 \\
0.0\end{array}$ & $\begin{array}{c}0,0 \\
0.0 \\
i=1\end{array}$ & $\begin{array}{l}6 \\
0 \\
0 \\
1 \\
1\end{array}$ & 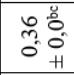 & 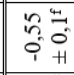 & 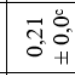 & 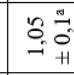 & \\
\hline & $\begin{array}{l}8 . \\
0.0 \\
0\end{array}$ & $\begin{array}{l}8: \\
0.0 \\
-10\end{array}$ & $\begin{array}{ll}\infty & 0 \\
0 & 0 \\
0 & 0 \\
1\end{array}$ & 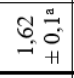 & $\begin{array}{l}\overrightarrow{0}=0 \\
0 \\
0\end{array}$ & 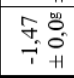 & 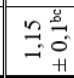 & 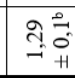 & $\begin{array}{l}y \\
0 \\
\text { Hi }\end{array}$ & \\
\hline & 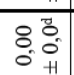 & $\begin{array}{l}0 \\
7=0 \\
0 \\
0\end{array}$ & 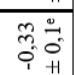 & 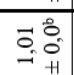 & 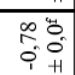 & Y. & $\mid$\begin{tabular}{l|l}
0 \\
0 \\
0 \\
0
\end{tabular} & 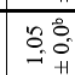 & 年 & \\
\hline & $\begin{array}{l}8.8 \\
8 \\
0.0 \\
0 \\
0\end{array}$ & $\begin{array}{c}90 \\
0 \\
10 \\
1+1\end{array}$ & 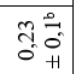 & 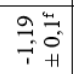 & $\begin{array}{l}0 \\
0 \\
0 \\
0 \\
0 \\
0 \\
0 \\
+1\end{array}$ & 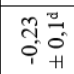 & $\begin{array}{l}\vec{a} \\
0 \\
-i \\
-i\end{array}$ & $\begin{array}{l}20 \\
0 \\
0\end{array}$ & 总 & \\
\hline & $\begin{array}{l}8_{0}^{0} \\
0_{0}^{0} \\
0^{\prime}\end{array}$ & 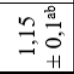 & 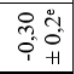 & 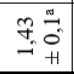 & $\begin{array}{l}0 \\
\infty \\
0 \\
0.0 \\
0 \\
0\end{array}$ & $\begin{array}{l}8.0 \\
80 \\
-10 \\
+1\end{array}$ & 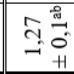 & 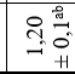 & $\begin{array}{l}. \\
\text { O. } \\
\text { H }\end{array}$ & \\
\hline & $8: 0$ & 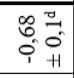 & $\begin{array}{l}0 \\
\pi_{0}^{\circ} \\
0 \\
\end{array}$ & $\begin{array}{l}9.0 \\
0.0 \\
1+1\end{array}$ & 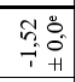 & $\begin{array}{l}\text { त̂: } \\
\text { त. } \\
0 \\
\text { H }\end{array}$ & 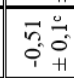 & 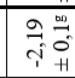 & 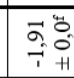 & \\
\hline & $\begin{array}{cc}8 & 0 \\
0 & 0 \\
0 & 0 \\
+1\end{array}$ & 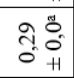 & 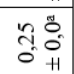 & $\begin{array}{l}80 \\
0.0 \\
0.0 \\
10\end{array}$ & $\begin{array}{l}\infty \\
0.0 \\
0.0 \\
0.0 \\
0\end{array}$ & $\begin{array}{l}\circ \\
0 \\
0\end{array}$ & 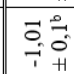 & $\begin{array}{l}n=0 \\
\therefore: 0 \\
0.0\end{array}$ & $\frac{0}{9}=0$ & \\
\hline & $\begin{array}{ll}8 \\
8 \\
0.0 \\
0 \\
0\end{array}$ & $\begin{array}{l}8 \\
8 \\
-10 \\
-1\end{array}$ & 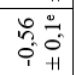 & $\begin{array}{l}n \\
\because 8 \\
0.0 \\
0.0\end{array}$ & 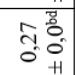 & $\begin{array}{l}n: \\
n \\
0.0 \\
0\end{array}$ & $\frac{10}{30}$ & $\begin{array}{l}m \\
m \\
0.0 \\
0\end{array}$ & $\begin{array}{l}3 \\
\vdots \\
0 \\
0 \\
+10\end{array}$ & \\
\hline & $\begin{array}{l}8 \\
8 \\
0.0 \\
0\end{array}$ & 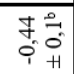 & 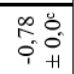 & 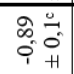 & 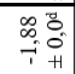 & 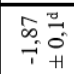 & $\mid \begin{array}{ll}\infty \\
0 \\
0 \\
1 \\
10\end{array}$ & 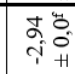 & 要 & \\
\hline & \begin{tabular}{ll}
8 & \multicolumn{2}{c}{} \\
8 & 0 \\
0 & +
\end{tabular} & 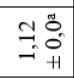 & $\begin{array}{l}\vec{m} \\
\vec{m} \\
\rightarrow \\
\end{array}$ & 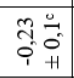 & 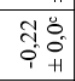 & $\begin{array}{l}0 \\
0 \\
0 \\
0.0 \\
0\end{array}$ & $\begin{array}{l}R_{0}^{0} \\
0.0 \\
0 .+1\end{array}$ & 웅 & 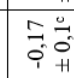 & \\
\hline & $0^{\circ}$ & $\begin{array}{c}\overrightarrow{0} \\
-5 \\
-1\end{array}$ & 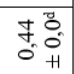 & 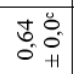 & $\begin{array}{l}n=0 \\
0 \\
-10 \\
-1\end{array}$ & $\begin{array}{l}\infty \\
\infty \\
0.0 \\
0.0 \\
0\end{array}$ & $\begin{array}{l}R_{0}^{0} \\
\hat{x}_{0}^{\circ}\end{array}$ & $\begin{array}{c}0 \\
0 \\
-10 \\
-0\end{array}$ & 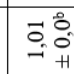 & \\
\hline & & $\begin{array}{l}1 \\
0 \\
+8 \\
5\end{array}$ & $\vec{k}$ & 5 & $\begin{array}{l}\bar{E} \\
0 \\
0 \\
+8 \\
5\end{array}$ & 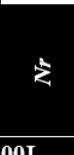 & 5 & \begin{tabular}{|l} 
E \\
至 \\
+8
\end{tabular} & & \\
\hline
\end{tabular}



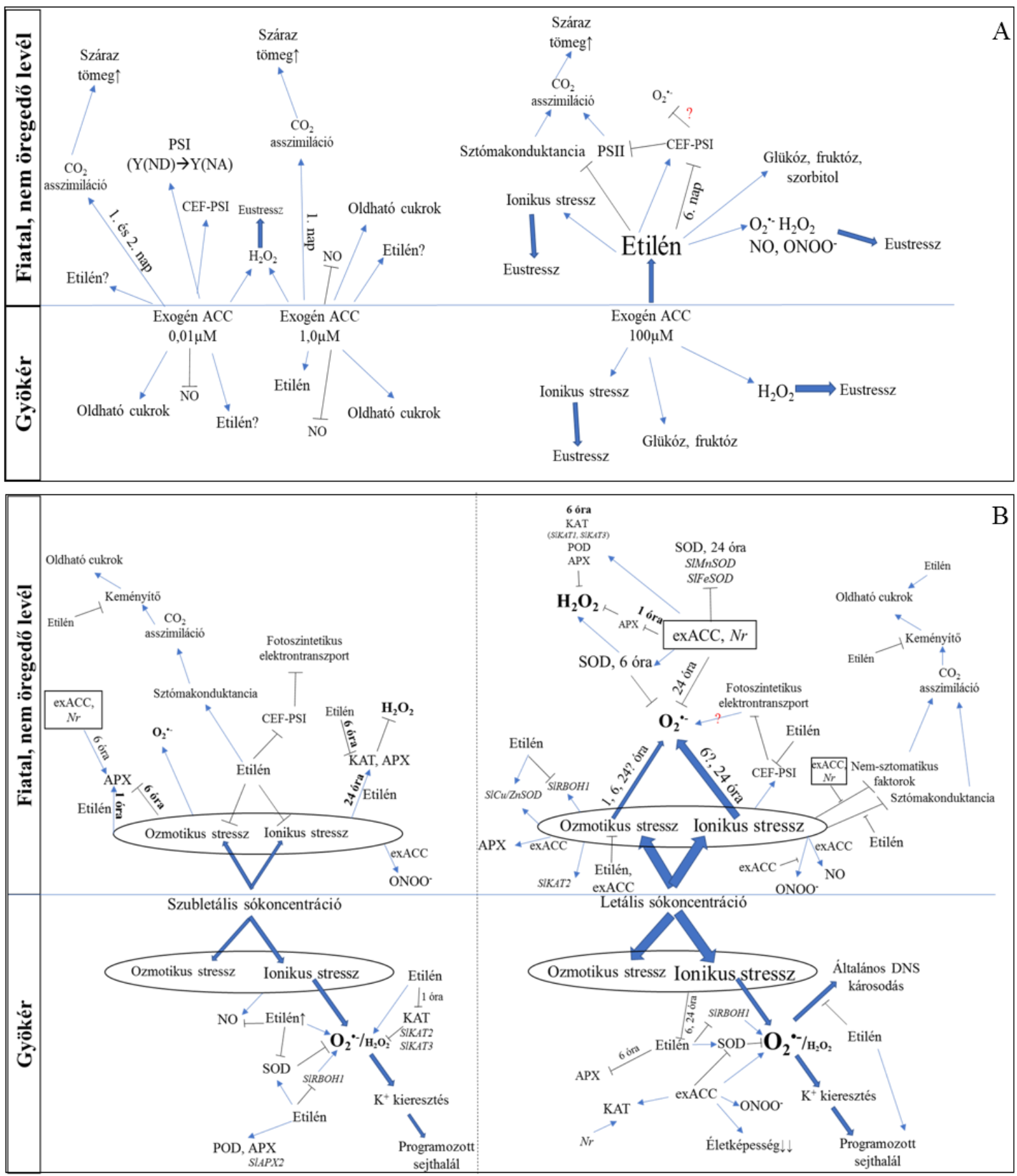

5. melléklet A fontosabb kísérleti eredmények összefoglalása. A gyökérzónában megjelenő, exogén ACC koncentrációk hatása a paradicsomnövények sóstressz akklimatizációban is fontos szerepet játszó fiziológiai folyamataira (A); a paradicsomnövények ET státuszának szerepe a sóstressz-válaszok kialakításában (B). exACC: exogén ACC. 